\title{
Evaluatie arbeidsmarktprognoses naar opleiding en beroep in 1992
}

Citation for published version (APA):

Borghans, L., van Eijs, P. W. L. J., \& de Grip, A. (1994). Evaluatie arbeidsmarktprognoses naar opleiding en beroep in 1992. Researchcentrum voor Onderwijs en Arbeidsmarkt, Faculteit der Economische Wetenschappen. ROA Reports No. 4 https://doi.org/10.26481/umarep.1994004

Document status and date:

Published: 01/01/1994

DOI:

10.26481/umarep.1994004

Document Version:

Publisher's PDF, also known as Version of record

\section{Please check the document version of this publication:}

- A submitted manuscript is the version of the article upon submission and before peer-review. There can be important differences between the submitted version and the official published version of record.

People interested in the research are advised to contact the author for the final version of the publication, or visit the DOI to the publisher's website.

- The final author version and the galley proof are versions of the publication after peer review.

- The final published version features the final layout of the paper including the volume, issue and page numbers.

Link to publication

\footnotetext{
General rights rights.

- You may freely distribute the URL identifying the publication in the public portal. please follow below link for the End User Agreement:

www.umlib.nl/taverne-license

Take down policy

If you believe that this document breaches copyright please contact us at:

repository@maastrichtuniversity.nl

providing details and we will investigate your claim.
}

Copyright and moral rights for the publications made accessible in the public portal are retained by the authors and/or other copyright owners and it is a condition of accessing publications that users recognise and abide by the legal requirements associated with these

- Users may download and print one copy of any publication from the public portal for the purpose of private study or research.

- You may not further distribute the material or use it for any profit-making activity or commercial gain

If the publication is distributed under the terms of Article $25 \mathrm{fa}$ of the Dutch Copyright Act, indicated by the "Taverne" license above, 


\section{EVALUATIE ARBEIDSMARKTPROGNOSES}

NAAR OPLEIDING EN BEROEP IN 1992

ROA-R-1994/4

L. Borghans

P. van Eijs

A. de Grip

RESEARCHCENTRUM VOOR ONDERWIJS EN ARBEIDSMARKT

Rijksuniversiteit Limburg

Faculteit der Economische Wetenschappen

Maastricht, april 1994 


\section{CIP-GEGEVENS KONINKLIJKE BIBLIOTHEEK, DEN HAAG}

\section{Borghans, L.}

Evaluatie arbeidsmarktprognoses naar opleiding en beroep in 1992 / L. Borghans, P. van Eijs, A. de Grip. - Maastricht : Researchcentrum voor Onderwijs en Arbeidsmarkt, Rijksuniversiteit Limburg, Faculteit der Economische Wetenschappen. - ([Rapport] / Researchcentrum voor Onderwijs en Arbeidsmarkt, ISSN 0922-8098; ROA-R-1994/4)

Met lit. opg.

ISBN 90-5321-126-8

Trefw.: arbeidsmarkt ; Nederland / onderwijs en arbeidsmarkt ; Nederland. 


\section{INHOUDSOPGAVE}

1. INLEIDING 1

1.1. Voorgeschiedenis 1

1.2. Uitgangspunten voor de evaluatie $\quad 2$

1.3. Doel en opzet prognoses 4

1.4. Opzet van het rapport $\quad 8$

2. DE OPZET VAN HET INFORMATIESYSTEEM 10

2.1. Inleiding 10

2.2. Algehele opzet prognoses 10

2.3. De data 14

2.4. Uitbreidingsvraag per beroep 18

2.5. Vervangingsvraag per beroep 23

2.6. Uitbreidingsvraag per opleidingstype 28

2.7. Vervangingsvraag per opleidingstype 31

2.8. Aanbod per opleidingstype 33

2.9. De confrontatie van vraag en aanbod 35

2.10. Kwalitatieve typeringen $\quad 37$

2.11. Risico-indicatoren 40

3. EEN METHODE VOOR DE EMPIRISCHE EVALUATIE 42

3.1. Inleiding 42

3.2. Problemen bij de empirische evaluatie 42

3.3. Een evaluatiecriterium 44

3.4. De oorzaak van voorspelfouten 46

3.5. De evaluatie van kwalitatieve typeringen 50

4. DE EMPIRISCHE EVALUATIE $\quad 52$

4.1. Inleiding 52

4.2. Bedrijfssectorprognoses CPB 52

4.3. Uitbreidingsvraag per beroep 60

4.4. Vervangingsvraag per beroep 70

4.5. Baanopeningen per beroepsklasse 79

4.6. Vervangingsvraag per opleidingstype 84

4.7. Het aanbod 88

4.8. De confrontatie van vraag en aanbod 92

$\begin{array}{ll}\text { 4.9. De arbeidsmarktindicator AMI } & 94\end{array}$

$\begin{array}{lr}\text { 5. BESLUIT } & 98\end{array}$

5.1. Inleiding 98

5.2. De resultaten van de empirische evaluatie 98

5.3. Aanbevolen veranderingen in opzet informatiesysteem en prognosemethodiek 
Bijlage I. De voorspelde en gerealiseerde typeringen voor de uitbreidingsvraag per beroepsklasse en de kans op een juiste typering

Bijlage II. De voorspelde en gerealiseerde typeringen voor de vervangingsvraag per beroepsklasse en de kans op een goede typering

Bijlage III. Prognoses en typeringen van de baanopeningen per beroepsklasse

Bijlage IV. De voorspelde typeringen voor de vervangingsvraag per opleidingstype en de kans op een juiste typering

Bijlage V. De voorspelde en de gereconstrueerde indicator van de toekomstige arbeidsmarktperspectieven (AMI) met hun typeringen 


\section{INLEIDING}

\subsection{Voorgeschiedenis}

In 1986 werd bij het Researchcentrum voor Onderwijs en Arbeidsmarkt een begin gemaakt met het opstellen van middellange-termijnprognoses voor de arbeidsmarktperspectieven van opleidingen en beroepen. Dit gebeurde in opdracht van het Ministerie van Onderwijs en Wetenschappen, dat beoogde een informatiesysteem te laten ontwikkelen, dat met name bruikbaar zou moeten zijn voor de studie- en beroepskeuzevoorlichting aan leerlingen en studenten in het voortgezet en hoger onderwijs. De eerste prognoses werden gebruikt voor de invulling van de arbeidsmarktmodule van I See! Dit was een geautomatiseerd informatiesysteem, tot stand gebracht door het Landelijk Dienstverlenend Centrum voor Studie- en Beroepskeuzevoorlichting (LDC), dat uit vele bronnen informatie over studie- en beroepskeuze bij elkaar bracht. Schooldekanen en andere intermediairs die betrokken zijn bij de keuzebegeleiding van leerlingen konden deze informatie via hun personal computer raadplegen en kregen zo, naast de andere informatie over studie- en beroepskeuze, ook zicht op de arbeidsmarktconsequenties van de keuzemogelijkheden. Thans wordt door het LDC een nieuw informatiesysteem uitgebracht onder de naam 'Traject', waarbij eveneens gebruik wordt gemaakt van de arbeidsmarktinformatie van het ROA. Daarnaast worden mede op basis van de ROA-prognoses door het LDC boekjes uitgebracht ten behoeve van de studie- en beroepskeuzevoorlichting. Naast het Ministerie van Onderwijs en Wetenschappen en het LDC wordt het informatiesysteem ook ondersteund door het Centraal Bestuur voor de Arbeidsvoorziening (CBA), dat de actuele data en de prognoses van het informatiesysteem gebruikt ter ondersteuning van het arbeidsvoorzieningsbeleid in het algemeen en de studie- en beroepskeuzevoorlichting in het bijzonder.

In 1987 werd in dit kader een eerste pilot-onderzoek afgerond, dat actuele arbeidsmarktinformatie en -prognoses bevatte voor het wetenschappelijk onderwijs (De Grip, Heijke en Vos, 1987, De Grip e.a., 1987a, 1987b en 1988). In 1989 volgden de eerste prognoses voor de volle breedte van het onderwijs (De Grip e.a., 1989 en De Grip, Heijke en Dekker, 1989). Hierbij werden voor 79 beroepsklassen en 53 opleidingstypen prognoses gegeven voor de ontwikkelingen in de periode tot en met 1992. Voor de beroepsklassen hadden deze prognoses betrekking op voorspellingen van de uitbreidingsvraag en de vervangingsvraag, te zamen de zogenaamde baanopeningen. Voor opleidingen werden bovendien prognoses opgesteld voor het verwachte aanbod, zodat er ook een confrontatie van vraag en aanbod plaats kon vinden, op basis waarvan er een typering kon worden gegeven van de verwachte toekomstige arbeidsmarktsituatie. Verder werden de prognoses aangevuld met actuele data en enkele indicatoren met betrekking tot de onderscheiden beroepsklassen en opleidingstypen.

De prognoses hadden betrekking op de periode 1985-1992, zodat thans de prognoseperiode van deze eerste voorspellingen van het ROA is verstreken. Rekening houdend met de vertraging die optreedt in de verzameling van het benodigde data-materiaal, doet zich momenteel voor het eerst de mogelijkheid voor deze arbeidsmarktprognoses naar beroep en opleidingen te evalueren. In 1991 verscheen er weliswaar reeds een eerste evaluatierapport (De Grip, Heijke en Berendsen, 1991), 
maar vanwege het feit dat destijds de eerste prognoseperiode nog niet geheel was verstreken had dit evaluatierapport met betrekking tot het empirisch gedeelte van de evaluatie slechts een voorlopig karakter. Naast deze empirische evaluatie bevatte dit rapport echter ook een terugblik op de gehanteerde methodiek, waarbij werd ingegaan op de sterke en zwakke punten van die aanpak en mogelijke uitbreidingsmogelijkheden van het informatiesysteem.

In dit tweede evaluatierapport zal deze lijn worden voortgezet. Het rapport zal derhalve bestaan uit drie hoofdbestanddelen. Ten eerste zullen de voorspelmethodiek die gehanteerd is in 1989 en de opzet van het informatiesysteem worden beschreven. De essentiële aannames waarop deze prognoses waren gebaseerd en de belangrijke beperkingen van de opzet zullen worden geïnventariseerd. Overigens is de methodiek die destijds werd gehanteerd op diverse onderdelen niet meer gelijk aan de huidige opzet van de prognoses, waardoor de gesignaleerde problemen mogelijk gedeeltelijk al achterhaald zullen zijn. Voor een goede evaluatie blijft deze terugblik op de gevolgde methodiek echter zeker nog zinvol.

Ten tweede bevat dit rapport een empirische evaluatie van de destijds gemaakte prognoses door middel van een vergelijking van de voorspelling met de gerealiseerde ontwikkelingen op de arbeidsmarkt. Gepoogd wordt deze empirische toetsing een systematisch karakter te geven. Op een aantal punten blijkt een confrontatie van voorspelling en realisatie echter niet of slechts in beperkte mate mogelijk te zijn. Aangezien voor een goed inzicht in de waarde van een prognose een beeld van de (gemiddelde) mate van doeltreffendheid nodig is, is het belangrijk dat prognoses in principe te evalueren zijn. Daarom zal voor de onderdelen waarvoor een evaluatie niet mogelijk is, aangegeven worden op welke wijze een evaluatie in de toekomst zou kunnen plaatsvinden. Daarbij zal ook besproken worden welke nieuwe data-bronnen hiervoor vereist zijn, of welke veranderingen in de methodiek nodig zijn om een evaluatie in de toekomst mogelijk te maken.

Ten derde bevat dit rapport, op basis van de bevindingen van de hierboven genoemde onderdelen, een bespreking van de tekortkomingen van de destijds gehanteerde aanpak. Na de prognoses zoals die in 1989 zijn opgesteld voor 1992, zijn nog enkele malen prognoses gemaakt. In 1990 zijn voorspellingen naar opleiding en beroep gemaakt voor 1994 (Dekker e.a. 1990 en ROA, 1991). Deze prognoses zijn in 1991 aangepast (Dekker e.a. 1992 en ROA, 1992a, 1992b) en in 1993 zijn prognoses opgesteld voor 1998 (Dekker e.a., 1993 en ROA, 1993a, 1993b). Bij deze nieuwe prognoses zijn, zoals reeds werd vermeld, nogal wat veranderingen aangebracht op de in 1989 gehanteerde methodiek. In de bespreking van de tekortkomingen zal daarom tevens besproken worden welke aanpassingen er reeds hebben plaatsgevonden en in hoeverre hiervan verwacht zou mogen worden dat ze de gesignaleerde problemen hebben opgelost. Ten slotte worden op grond van deze bevindingen conclusies getrokken voor de toekomst en zal een overzicht gegeven worden van de mogelijke verbeteringen die zouden kunnen plaatsvinden in de opzet van de arbeidsmarktprognoses.

\subsection{Uitgangspunten voor de evaluatie}

Hoewel met het opstellen van een evaluatie vooral wordt teruggeblikt naar het moment waarop de 
prognose werd opgesteld en naar de periode waarop de prognoses betrekking hadden, is een evaluatie van de prognoses ook van groot belang met het oog op toekomstige prognoseactiviteiten.

Voor de gebruikers van de prognoses over de toekomstige arbeidsmarkt naar opleiding en beroep is het nuttig informatie te hebben over de mate van betrouwbaarheid van de prognoses. In Borghans (1993) wordt getoond dat publieke voorspellingen ter ondersteuning van de studiekeuze een positieve invloed op de studiekeuze van leerlingen en daarmee op de werking van de arbeidsmarkt hebben, mits leerlingen een redelijk beeld hebben van de bruikbaarheid van deze prognoses. Voor het inzicht in de bruikbaarheid van de prognoses zijn twee zaken van belang. Ten eerste dient het voor leerlingen duidelijk te zijn op grond van welke argumenten een prognose tot stand is gekomen. Het totaalbeeld dat een prognose schetst dient verbijzonderd te worden naar de factoren waaruit zij is opgebouwd, zodat duidelijk wordt op grond waarvan bepaalde ontwikkelingen verwacht worden. Dit maakt het mogelijk de prognoses te vergelijken met de eigen verwachtingen over de toekomstige arbeidsmarktontwikkelingen en/of diverse andere informatiebronnen. Ten tweede is het van belang dat leerlingen een beeld hebben van de gemiddelde trefzekerheid van de voorspellingen, omdat dit mede bepaald in welke mate zij rekening zouden moeten houden met de prognoses van het informatiesysteem. Om aan deze eis te voldoen is het derhalve belangrijk na te gaan op welke punten de prognoses redelijk trefzeker zijn, en op welke punten de onzekerheden liggen. Ook moet bekeken worden op welke manier de mate van onzekerheid tot uitdrukking komt in de wijze waarop de prognoses worden gepubliceerd.

Ook voor de opstellers van de prognoses is een goede evaluatie van de prognoses uit het verleden van groot belang. Bij het opstellen van prognoses wordt op basis van inzichten in het functioneren van de arbeidsmarkt een keuze gemaakt tussen de vele mogelijke manieren om de arbeidsmarkt te modelleren. Indien alleen de kwaliteit van de data de kwaliteit van de prognoses zou bepalen, zou de enige les die uit de evaluatie getrokken kan worden, een roep om meer of betere data zijn. Een evaluatie van de prognoses kan echter ook nieuwe inzichten geven over de bruikbaarheid van de gehanteerde methode. Zeker voor prognoses binnen een informatiesysteem dat zich nog in een ontwikkelfase bevindt zal een grondige evaluatie ook de sterke en zwakke punten van de gevolgde methode aan het licht kunnen brengen.

Als derde groep hebben de opdrachtgevers belang bij een evaluatie van de voorspellingen. Aan de ene kant kan deze evaluatie informatie geven omtrent de prioriteiten die gelegd moeten worden bij de verdere ontwikkeling van het informatiesysteem. Aan de andere kant is het voor de opdrachtgevers belangrijk te weten in hoeverre de prognoses bruikbaar zijn voor hun doelgroep.

Ook Granger en Newbold (1986) pleiten, gezien het cruciale karakter van de modelkeuze, voor een grondige evaluatie als middel om de voorspelmethodiek te verbeteren. Volgens hen moet een evaluatie worden uitgevoerd op twee niveaus: het subjectieve en het objectieve niveau. Op het subjectieve niveau worden de prognoses en de realisaties zorgvuldig vergeleken en zoekt men naar factoren die de oorzaak kunnen zijn van de voorspelfouten. Hierbij wordt met name gekeken naar de extreem grote voorspelfouten. Daarnaast kan bekeken worden of er incidentele redenen waren voor het voorkomen van dergelijke uitschieters. Hierbij dient men zich af te vragen of de incidentele 
factor al voorzien had kunnen worden op het moment dat de prognose werd opgesteld.

Een gevaar van deze subjectieve methode is echter dat de evaluatie kan vervallen in een opeenhoping van incidenten. Zeker bij het veelvuldig voorkomen van zulke incidenten moet men op zoek naar structurele tekortkomingen in de gehanteerde prognosemethodiek. Daarom is de tweede fase, de objectieve evaluatie, volgens Granger en Newbold van nog groter belang. Daarbij stellen zij drie vragen die een objectieve evaluatie in ieder geval moet beantwoorden (Granger en Newbold, 1986, blz. 277):

(1) Zijn de voorspellingen beter dan de beschikbare alternatieven?

(2) Hoe 'goed' zijn de voorspellingen?

(3) Kan de methode waarmee de voorspellingen zijn opgesteld zodanig aangepast worden dat een verbeterde voorspelkwaliteit verwacht mag worden?

Bij de empirische evaluatie zullen deze drie vragen als uitgangspunt worden genomen. Hiervoor moeten deze uitgangspunten nog nader ingevuld worden. Er moet bepaald worden wat het alternatief voor de gemaakte prognoses is, om zo de kwaliteit van de prognoses te kunnen vergelijken en invulling te geven aan het begrip 'goede voorspelling'. Deze punten komen aan de orde in hoofdstuk 3.

\subsection{Doel en opzet prognoses}

Om te komen tot een evaluatie van de prognoses die in het kader van het informatiesysteem van het ROA zijn gemaakt, moet worden vastgesteld in hoeverre deze prognoses voldoen aan de doeleinden waarvoor ze zijn opgesteld. Daarvoor is het belangrijk om een duidelijk beeld te hebben van de algehele prognose-opzet en van de doelstellingen van de prognoses zoals zij destijds zijn gemaakt. Dit maakt het mogelijk om bij de evaluatie zowel te kijken naar de doeltreffendheid van de prognoses, alsook naar de mate waarin de gehanteerde opzet gericht is op de gestelde doelen.

\section{Doelstelling prognoses}

In het rapport uit 1989 werd een primair en een secondair doel van het informatiesysteem onderwijs-arbeidsmarkt geformuleerd. 'Het ROA-informatiesysteem onderwijs-arbeidsmarkt heeft vooralsnog primair als doel informatie te genereren die bruikbaar is voor de studie- en beroepskeuze. Daarnaast zou dit ROA-informatiesysteem echter in principe ook van nut kunnen zijn voor de capaciteitsplanning in het onderwijs, het arbeidsvoorzieningenbeleid, het economische structuuren technologiebeleid en het personeelsbeleid van zowel overheid als bedrijfsleven.' (De Grip, Heijke en Dekker, 1989, blz. 1).

Omdat de tweede doelstelling hier slechts als optie gepresenteerd wordt en bovendien erg algemeen van karakter is, wordt in dit evaluatierapport met name gerefereerd aan de eerstgenoemde doelstelling. Dit betekent dat de prognoses en de prognose-opzet steeds tegen het licht van de bruikbaarheid voor studie- en beroepskeuze gehouden worden. 
De doelstelling om informatie te genereren die bruikbaar is voor de studie- en beroepskeuzevoorlichting heeft voor deze evaluatie een tweetal consequenties. Ten eerste dient de opzet van het informatiesysteem zodanig te zijn dat de gegenereerde gegevens ondersteuning kunnen geven aan de studie- of beroepskeuzebeslissing van een individuele leerling. Dat wil zeggen dat de informatie:

(1) relevant moet zijn voor de leerlingen;

(2) op individueel niveau betekenis moet hebben;

(3) gepresenteerd wordt op een wijze die voor leerlingen goed interpreteerbaar is.

De eerste voorwaarde, de relevantie voor de leerlingen, betekent dat de prognoses betrekking moeten hebben op aspecten die van belang kunnen zijn voor de studie- of beroepskeuzebeslissingen. Dat wil zeggen dat de prognoses inzicht moeten geven in de situatie op de arbeidsmarkt die een leerling aan zal treffen vanaf het moment dat hij, na zijn studie te hebben voltooid, tot de arbeidsmarkt toetreedt. Deze voorwaarde legt dus eisen op aan het tijdstip waarop de prognoses betrekking hebben - ze moeten betrekking hebben op de periode nadat leerlingen de school verlaten hebben - en aan de groep op de arbeidsmarkt waarvoor ze relevant zijn - de schoolverlaters.

De tweede voorwaarde betreft de vereiste dimensie van de informatie. Vanuit de studie- en beroepskeuzedoelstelling dienen de prognoses bruikbaar te zijn voor het maken van een individuele keuze voor een bepaalde opleiding of beroep. Voor de leerling die voor een studiekeuze staat, is het relevant te weten welke situatie hij op de arbeidsmarkt aan zal treffen na afloop van de gekozen opleiding. Bepaalde ontwikkelingen zijn vanuit een algemeen gezichtspunt zeer relevant voor de beschrijving van de arbeidsmarkt, maar zijn voor individuen pas bruikbaar na een vertaling naar het individueel niveau. Zo is de totale werkgelegenheidsgroei voor een bepaalde opleidingscategorie vanuit een beleidsoogpunt interessant, maar is het voor een leerling belangrijker wat zijn of haar individuele kans op bepaald soort werk na afloop van de studie zal zijn.

De derde voorwaarde voor de opzet van het prognose-systeem om bruikbaar te zijn voor studie- en beroepskeuzevoorlichting is de interpreteerbaarheid van de informatie. Om bruikbaar te zijn voor leerlingen dienen de prognoses geformuleerd te zijn in termen die begrijpelijk zijn voor iemand die niet volledig ingewijd is in de arbeidsmarktproblematiek ${ }^{1}$. De prognoseresultaten dienen zoveel mogelijk geformuleerd te worden in algemeen gehanteerde begrippen en zo min mogelijk statistisch of economisch jargon bevatten. Met name met betrekking tot statistische uitspraken over de betrouwbaarheid van de prognoses is een vertaling van groot belang. De verbetering van de interpreteerbaarheid van de arbeidsmarktgegevens kan overigens van twee kanten komen. Immers, het kan ook zinvol zijn om, zoals momenteel ook in het kader van de basisvorming wordt beoogd, leerlingen meer inzicht te geven in het functioneren van de arbeidsmarkt, om zo de begrijpelijkheid van de arbeidsmarktinformatie te vergroten.

Een tweede consequentie van de doelstelling om informatie te genereren die bruikbaar is voor de

1. Mede om een juiste interpretatie van de voorspellingen te bevorderen werden de gegevens van het informatiesysteem overigens niet rechtstreeks aan de leerlingen verstrekt, maar werd I-See! beschikbaar gesteld aan de schooldecanen. 
studie en beroepskeuze is dat ook de empirische evaluatie zal plaatsvinden vanuit dit gezichtspunt. Dit betekent dat het gehanteerde evaluatiecriterium, waarmee de omvang van de voorspelfouten wordt vastgesteld, vooral moet laten zien welke consequenties deze voorspelfouten hebben voor de individuele studie- en beroepskeuze. De keuze van het evaluatiecriterium wordt besproken in paragraaf 3.3.

\section{Opzet prognoses}

Figuur 1.1 geeft een schematisch overzicht van de opzet van de prognosemethodiek. Aan de vraagkant dienen de werkgelegenheidsprognoses naar bedrijfssector van het Centraal Planbureau (CPB) als externe informatiebron. Deze prognoses hadden destijds betrekking op 22 bedrijfssectoren. Het voorspelde aantal werkzame personen in deze bedrijfssectoren is vervolgens vertaald naar de werkgelegenheid in 79 beroepsklassen. Vergeleken met de situatie in 1985 levert deze voorspelde vraag naar beroepen de verwachte uitbreidingsvraag per beroepsklasse op. Hieraan wordt een prognose van de verwachte vervangingsvraag toegevoegd. Te zamen leveren de uitbreidingsvraag en de vervangingsvraag het verwachte aantal baanopeningen op. Verondersteld is dat deze baanopeningen de voor studie- en beroepskeuzedoeleinden relevante grootheid zijn. Nieuwkomers op de arbeidsmarkt kunnen immers niet zonder meer de reeds werkzame personen uit hun baan verdringen. Op grond van het instroomprofiel in het verleden is ook bepaald hoeveel van deze baanopeningen beschikbaar zijn voor schoolverlaters.

Naast deze prognoses van het aantal baanopeningen per beroepsklasse worden in het informatiesysteem ook actuele data en indicatoren per beroepsklasse opgenomen. De actuele data betreffen het aantal werkenden in de betreffende beroepsklasse, de verdeling over de beroepsgroepen, de verdeling van de werkenden over leeftijdsklassen, opleidingscategorieen en opleidingstypen, bedrijfssectoren en bedrijfsklassen, en het aandeel zelfstandigen, plus de trends in deze cijfers. De achterliggende idee is dat dergelijke informatie kan bijdragen aan de 'horizonverbreding' bij de studie- en beroepskeuzevoorlichting en op de verschillende punten inzicht geeft in enkele arbeidsmarkt-relevante kenmerken van de desbetreffende beroepsklasse.

De indicatoren betreffen de absorptiegraad van personen jonger dan 30, de branchespreiding en de conjunctuurgevoeligheid van de werkgelegenheid. De absorptiegraad geeft aan hoeveel jongeren in dit beroep werkzaam zijn, vergeleken met andere beroepen. De branchespreiding en de conjunctuurgevoeligheid zijn beide zogenaamde risico-indicatoren. De branchespreiding geeft aan in welke mate de werkgelegenheid in deze beroepsklasse gespreid is over verschillende bedrijfssectoren. Als deze spreiding groot is, zal een onverwachte verandering in een bepaalde bedrijfstak relatief weinig invloed hebben op de ontwikkelingen in dat beroep. Verder geeft de branchespreiding ook aan dat, indien er een tegenvallende vraag in een van de bedrijfstakken optreedt, er waarschijnlijk wel mogelijkheden zijn om in andere bedrijfssectoren werk te vinden. De conjunctuurgevoeligheid geeft aan in welke mate de werkgelegenheid van het beroep meefluctueert met de conjunctuurgolven. Een hoge conjunctuurgevoeligheid betekent in de eerste plaats een grotere kans dat in de latere loopbaan de arbeidsmarktperspectieven op een gegeven moment verslechteren. In de tweede plaats duidt het op een grotere kans dat de prognoses niet uit zullen komen. 
$-7-$

Figuur 1.1. De opzet van het prognosemodel van het informatiesysteem onderwijs-arbeidsmarkt

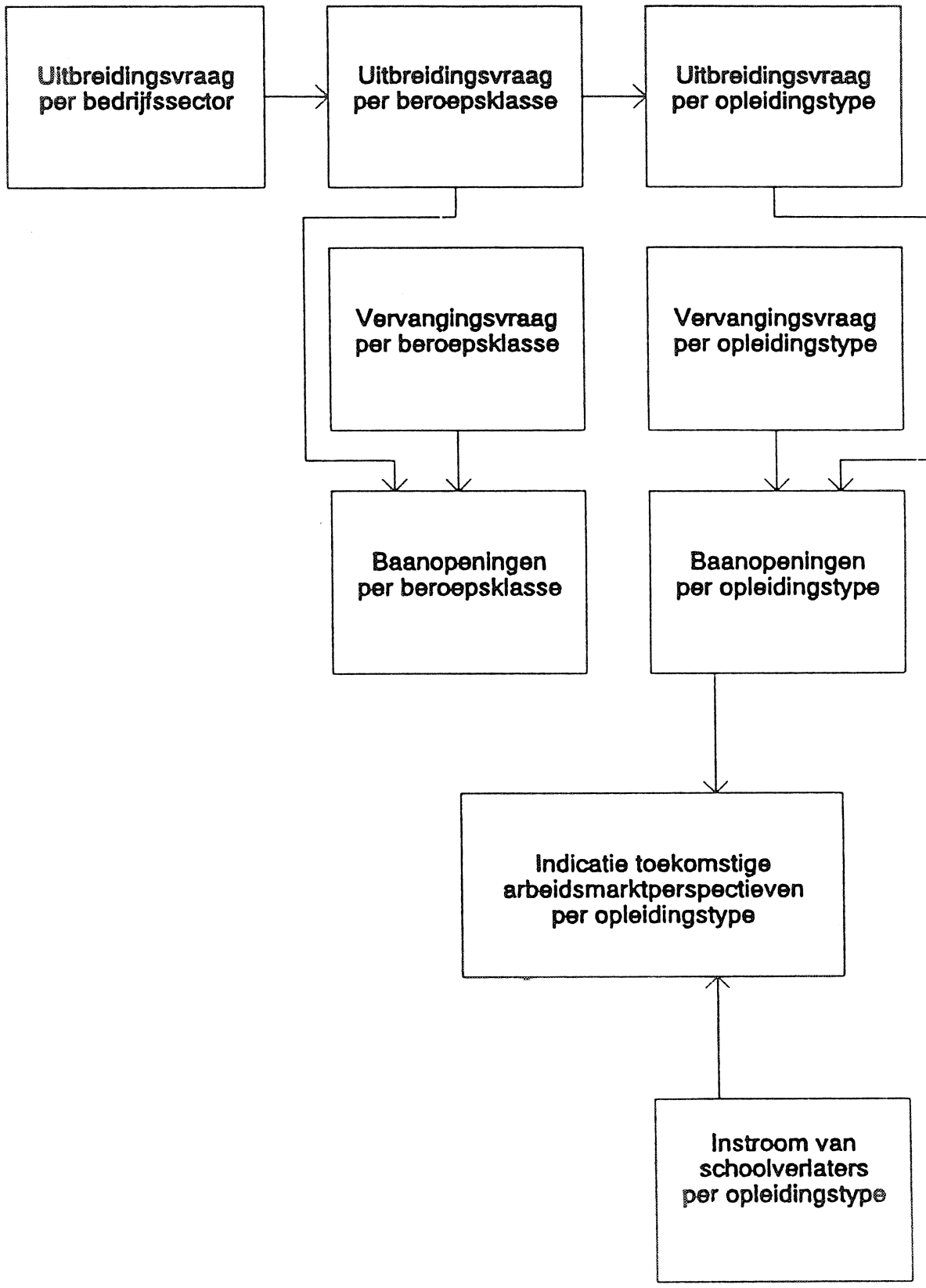

De uitbreidingsvraag per beroep is door middel van een verdeelmodel omgezet naar de uitbreidingsvraag per opleidingstype. De vervangingsvraag per opleidingstype is apart berekend, omdat deze niet uit de vervangingsvraag per beroep kan worden afgeleid. Te zamen vormen de vervangingsvraag en de uitbreidingsvraag de totale vraag naar nieuwkomers met de desbetreffende opleidingsachtergrond.

Naast de vraagprognoses is per opleidingstype op basis van de Skill-, Rhobos- en Worsaprognoses $^{2}$, aangevuld met additionele gegevens over het niet-reguliere onderwijs en het deeltijd-

2. Skill, Rhobos en Worsa vormden de ramingen die destijds door het Ministerie van Onderwijs en Wetenschappen gehanteerd werden voor de in-, door- en uitstroom van het onderwijs. De Skillprognoses hadden betrekking op alle opleidingsniveaus, Worsa betrof een verbijzondering hiervan voor 
onderwijs, een prognose gemaakt van het verwachte aanbod van schoolverlaters op de arbeidsmarkt tussen 1985 en 1992 . Het quotiënt van het totale aanbod van nieuwkomers en de totale vraag naar nieuwkomers vormt de AMI (ArbeidsMarktIndicator, thans ITA: Indicator Toekomstige Arbeidsmarkt). Deze verhouding geeft een indicatie van de spanning tussen vraag en aanbod in de beschouwde periode. Omdat er in het gehanteerde model geen rekening wordt gehouden met eventuele aanpassingen van de arbeidsmarkt op deze spanningen tussen vraag en aanbod, moet deze spanningsindicator niet zonder meer beschouwd worden als het verwachte aanbodoverschot of -tekort. Uiteraard zullen zowel de vraag-als de aanbodzijde van de arbeidsmarkt gedeeltelijk inspelen op deze spanningen, zodat bijvoorbeeld een overschot aan nieuwkomers met een bepaalde opleiding niet alleen tot uiting hoeft te komen in een hoge werkloosheid, maar ook kan leiden tot achterblijvende lonen, meer kans op banen buiten het beoogde werkveld of andere verslechteringen van de arbeidsmarktsituatie.

Naast de prognose van de toekomstige arbeidsmarktsituatie worden voor de opleidingen, net als bij de beroepen, aanvullende gegevens verstrekt. Allereerst wordt wederom een beeld gegeven van de actuele arbeidsmarktsituatie. Deze informatie heeft betrekking op het aantal werkenden, de belangrijkste beroepsklassen en beroepsgroepen en de werkloosheid (alsmede het aandeel van schoolverlaters in de werkloosheid), met een indicatie van de trendmatige ontwikkeling van deze cijfers. Daarnaast wordt een indicatie gegeven van de beroepenspreiding en de branchespreiding. Net als bij beroepen geven deze spreidingsindicatoren een indruk van de gevoeligheid van de prognoses, maar ook meer in het algemeen wordt op deze wijze aangegeven in hoeverre men met het kiezen voor een bepaalde opleiding afhankelijk is van de arbeidsmarktsituatie voor een bepaalde beroepsklasse of een bepaalde bedrijfssector.

Ten behoeve van de studie- en beroepskeuzevoorlichting worden de kwantitatieve gegevens van de prognoses, actuele data en indicatoren getransformeerd naar kwalitatieve typeringen. Op basis van de waargenomen waarden van de variabelen is telkens een classificatie gemaakt op basis van een vijf-punts-schaal. Hieraan is een typering gekoppeld: 'erg laag', 'laag', 'gemiddeld', 'hoog' of 'erg hoog'. De bedoeling van deze kwalititatieve typeringen is om de kwantitatieve cijfers van de prognoses, indicatoren en actuele data beter toegankelijk te maken voor mensen die niet gewend zijn met dergelijke cijfers te werken. Ten eerste hoeft men zich nu niet te verdiepen in de meeteenheid van de variabele. Ten tweede krijgt men meteen een relatieve typering, zodat men geen inzicht hoeft te hebben in de spreiding van de variabele. Ten derde zorgt de verdeling in intervallen voor een typering die minder exact overkomt dan de cijfers zelf. Hiermee wordt de suggestie van nauwkeurigheid tot achter de komma vermeden en krijgen met name de arbeidsmarktprognoses een zekere bandbreedte.

\subsection{Opzet van het rapport}

De rest van dit rapport is als volgt opgebouwd. In hoofdstuk 2 wordt de opzet van het informatiesysteem besproken. Hierin wordt ingegaan op de wijze waarop de prognoses tot stand 
$-9-$

zijn gekomen en hoe op basis van deze voorspellingen, aangevuld met actuele data en indicatoren in het informatiesysteem een beeld geschetst wordt van de ontwikkelingen op de arbeidsmarkt naar opleiding en beroep en met name het toekomstig arbeidsmarktperspectief van opleidingstypen. Hierbij wordt allereerst ingegaan op de algehele opzet van de prognoses en de gebruikte data. Vervolgens worden de verschillende onderdelen van het informatiesysteem besproken en tenslotte wordt ingegaan op de kwalitatieve typeringen en de risico-indicatoren.

In hoofdstuk 4 worden, mede op basis van de bevindingen in het hoofdstuk over de opzet van het informatiesysteem de onderdelen, voor zover dat mogelijk is, empirisch geëvalueerd. Daartoe wordt allereerst in hoofdstuk 3 een evaluatiesystematiek beschreven die als uitgangspunt hiervoor dient. Op basis van deze empirische evaluatie wordt niet alleen de algehele voorspelkwaliteit van het informatiesysteem gemeten, maar wordt ook ingegaan op de vraag op welke punten de gehanteerde methode met name tekortschiet. Hierdoor kan bekeken worden welke veranderingen aan de methodiek waarschijnlijk de kwaliteit van het systeem zullen verbeteren.

In hoofdstuk 5, tenslotte, worden de bevindingen van zowel het beschouwende als het empirische gedeelte op een rij gezet. Dit gebeurt aan de hand van een drietal overzichtstabellen. De eerste tabel bevat enkele belangrijke kencijfers over de voorspelkwaliteit van de onderdelen van het prognosemodel. De tweede tabel bevat een overzicht van facetten van de opzet van het informatiesysteem die op grond van de bevindingen in dit rapport aangepast zouden moeten worden, of reeds aangepast zijn. De derde tabel bevat een vergelijkbare lijst met mogelijke aanpassingen met betrekking tot de prognosemethodiek. 


\section{DE OPZET VAN HET INFORMATIESYSTEEM}

\subsection{Inleiding}

Omdat de primaire doelstelling van de prognoses is om de toekomstige arbeidsmarktpositie van schoolverlaters te schetsen, worden bepaalde facetten van de toekomstige arbeidsmarkt belicht die vanuit deze optiek relevant zijn. In dit hoofdstuk worden de belangrijkste uitgangspunten van de opzet van het informatiesysteem en de methodiek waarmee deze invulling hebben gekregen geïnventariseerd. Doel van deze inventarisatie is een overzicht te krijgen van de mogelijk sterke en zwakke punten van het informatiesysteem, zodat duidelijk kan worden welke onderdelen bij de verdere ontwikkeling van de prognosemethodiek aandacht verdienen. Bovendien levert deze beschouwing van de gevolgde opzet en methodiek enkele aandachtspunten voor de empirische evaluatie.

\subsection{Algehele opzet prognoses}

\section{Arbeidsmarktperspectief versus kans op werk}

De spil van de prognoses van het informatiesysteem is een confrontatie tussen vraag en aanbod op de arbeidsmarkt. Bij deze confrontatie - die plaatsvindt op het niveau van opleidingstypen komen de verschillende onderdelen van het informatiesysteem samen in de constructie van de AMI, of ITA, de indicator van de toekomstige arbeidsmarkt. Ondanks de sleutelpositie in het informatiesysteem is het moeilijk om een eenduidige interpretatie te geven van de uitkomsten van deze confrontatie van vraag en aanbod.

Werkloosheid is de ergste en zeker de meest zichtbare uiting van een slechte aansluiting tussen onderwijs en arbeidsmarkt. Het is dan ook niet verwonderlijk dat een voorspelling van een slecht arbeidsmarktperspectief doorgaans geïnterpreteerd wordt als een voorspelling van een lage kans op werk met de betreffende opleiding. Hierbij wordt vaak de veronderstelling gemaakt dat als het aanbod groter is dan de verwachte vraag, een groep ter grootte van het verschil werkloos zal moeten worden. Omgekeerd zal een vraag die groter is dan het aanbod leiden tot een aantal openstaande vacatures ter grootte van dit verschil.

Toch is dit primaat van werkloosheid bij de beschouwing van problemen bij de aansluiting tussen onderwijs en arbeidsmarkt niet terecht. Werkloosheid is zeker niet de enige wijze waarop een verwachte discrepantie tussen vraag en aanbod tot uiting zou kunnen komen. Als er een spanning bestaat tussen de gevraagde en aangeboden hoeveelheid arbeid zal de arbeidsmarkt allerlei aanpassingsprocessen vertonen. In de neoklassieke benadering zou een dergelijke spanning louter leiden tot een aanpassing van het loon. Als er meer aanbod is dan vraag naar een bepaalde opleiding zouden, vanuit deze gedachte, de lonen voor mensen met de desbetreffende opleiding dalen. Zelfs al zou dit geen consequenties hebben voor het aanbod - omdat de gevolgde scholing voor de op dat moment op de arbeidsmarkt instromende schoolverlaters immers al vastligt - dan nog kan een verlaging van het loon, door een grotere vraag naar deze goedkoper geworden arbeid, 
leiden tot een aanpassing van de vraag aan het aanbod.

In de werkelijkheid worden echter veel fricties tussen vraag en aanbod niet 'opgelost' door loonaanpassingen. Als het aanbod de vraag overstijgt zal dit de aanbieders onder druk zetten. In een dergelijke situatie zullen zij vanwege de verhoogde onderlinge concurrentie genoegen moeten nemen met mindere arbeidsvoorwaarden en zullen zij sneller moeten uitwijken naar banen die voor hen minder aantrekkelijk zijn (bijvoorbeeld op een lager niveau). Ten slotte betekent een aanbodoverschot vanzelfsprekend ook een vergrote kans om überhaupt geen werk te vinden of om veel langer op zoek te zijn naar werk dan normaal het geval is. In het algemeen zal een aanbodoverschot dus leiden tot een situatie waarin de aanbieders op de arbeidsmarkt slechter af zijn dan de vragers. Een aanbod dat groter is dan de vraag betekent derhalve hoe dan ook een slecht arbeidsmarktperspectief. Zelfs in het theoretische geval dat alle aanpassingen via het loonmechanisme tot stand komen zullen werknemers bij een vergroot aanbod slechter af zijn, omdat zij genoegen zullen moeten nemen met een lager loon.

Het feit dat een discrepantie tussen vraag en aanbod niet per sé hoeft te leiden tot werkloosheid en vacatures volgt onmiddellijk uit de in 1989 gemaakte prognoses van vraag en aanbod per opleidingstype die in dit rapport worden geëvalueerd. Als alle overschotten en tekorten aan arbeid met een bepaalde opleiding worden samengenomen zou dit bij deze aanname geresulteerd hebben in - alleen al door de komst van schoolverlaters op de arbeidsmarkt - een werkloosheid van 736.000 personen en 299.000 openstaande vacatures. Dit is respectievelijk $42 \%$ en $17 \%$ van de totale instroom.

\section{Aanpassingsprocessen}

Discrepanties tussen vraag en aanbod zullen derhalve nogal eens leiden tot aanpassingsprocessen op de arbeidsmarkt. Borghans en Heijke (1993) laten zien dat, omdat deze aanpassingen in principe ongunstig zijn voor de ruime kant van de markt, het verschil tussen de voorspelde vraag en het voorspelde aanbod, zonder dat in deze prognoses de aanpassingsmechanismes worden opgenomen, een indicatie geeft van de te verwachten omvang van deze aanpassingsreacties in combinatie met de uiteindelijk resulterende werkloosheid of vacatures. Het verschil tussen vraag en aanbod is dus ter dege een indicatie van het arbeidsmarktperspectief. Van Eijs (1994) merkt hier overigens bij op dat de mate van aanpassing bij een gegeven grootte van de discrepantie tussen vraag en aanbod per opleidingstype kan verschillen. Afhankelijk van de elasticiteiten in het aanpassingsmechanisme zal bij de ene opleiding een kleine aanpassing voldoende zijn om de vraag weer in evenwicht te krijgen met het aanbod, terwijl bij een andere opleiding een grote aanpassing vereist is.

Op grond van deze redenering kan geconcludeerd worden dat een algemene spanningsindicator als maatstaf voor de arbeidsmarktperspectieven van schoolverlaters in principe gebaseerd moet zijn op prognoses van vraag en aanbod voordat aanpassingen plaatsvinden. Daarbij zou het overigens zeer waardevol zijn als niet alleen de spanning tussen vraag en aanbod voorspeld zou worden, maar ook een uitspraak gedaan zou kunnen worden over welke aanpassingen in een concreet geval te verwachten zijn. 
Met betrekking tot het eerste punt doet zich, bij de prognoses die hier worden geëvalueerd, het probleem voor dat de aanpassingsprocessen gedeeltelijk al in het prognosemodel zijn opgenomen. In het opleidingen-model wordt de vraag naar bepaalde opleidingstypen mede bepaald door de samenstelling van het opleidingsniveau van het aanbod. De interpretatie van dit aanpassingsmechanisme is dat bij een groter wordend aanbod van hoger opgeleiden de werkgevers hun vraag aan zullen passen. In het licht van bovenstaande redenering betekent deze aanpassing echter mogelijk reeds een verslechtering van de positie van de hoger opgeleiden. Doordat de aanpassing reeds in het model is opgenomen, komt zij niet meer tot uiting in het op basis van de confrontatie tussen vraag en aanbod verwachte arbeidsmarktperspectief. Om deze reden is bij de recentelijk opgestelde prognoses voor 1998 de invloed van aanbodfactoren niet meer opgenomen bij de bepaling van de vraag naar opleidingstypen (Borghans en Heijke, 1993). Bovendien wordt in dit nieuwe opleidingenmodel expliciet rekening gehouden met het feit dat aanpassingsprocessen bij een bepaald opleidingstype, via substitutie en verdringing, invloed kunnen hebben op de arbeidsmarktperspectieven van andere opleidingen.

Het expliciet modelleren van de aanpassingsmechanismen heeft als voordeel dat hierdoor voorspeld kan worden op welke wijze een vraag-aanbod-discrepantie zich zal uiten. Omdat echter verwacht kan worden dat het voorspellen van het algemene arbeidsmarktperspectief veel beter mogelijk is, dan een precieze prognose van de concrete wijze waarop dit zich zal manifesteren, lijkt het echter verstandig in ieder geval een voorspelling te maken van dit algemene perspectief, en de prognose van de uitingsvorm op te nemen als een verbijzondering hiervan. De informatieve waarde van het informatiesysteem zou derhalve vergroot kunnen worden door, bijvoorbeeld op basis van informatie uit schoolverlatersenquêtes, uitgaande van het voor een bepaald opleidingstype verwachte arbeidsmarktperspectief, een indicatie te geven van de verwachte werkloosheid, mate van onderbenutting, beloning, e.d.

\section{Niveau versus verandering}

Omdat de prognoses voor vraag en aanbod op de arbeidsmarkt altijd gebaseerd zijn op de ontwikkelingen van vraag en aanbod in het verleden, geldt impliciet dat indien de aanpassingsprocessen niet in het model verwerkt zijn, de prognoses gemaakt worden onder de veronderstelling dat de omstandigheden waaronder arbeid met een bepaalde opleiding wordt aangenomen gelijk blijven aan die in het recente verleden. De verwachting met betrekking van het arbeidsmarktperspectief moet dan ook opgevat worden als een verwachting van de verandering in die omstandigheden. Per saldo kan dit betekenen dat bij een opleiding met in de huidige situatie zeer gunstige omstandigheden, waarbij een slecht perspectief wordt verwacht, de uiteindelijke omstandigheden die schoolverlaters aan zullen treffen als ze de arbeidsmarkt betreden toch nog beter zijn dan bij een opleiding met een gunstig perspectief, maar zeer slechte omstandigheden op het moment. De perspectieven zijn als het ware gerelateerd aan de omstandigheden die een leerling gezien de opleiding kan verwachten. Concreet betekent dit, extreem gesteld, dat bijvoorbeeld het lager technisch onderwijs niet onmiddellijk aantrekkelijk wordt voor een potentiële student technische wetenschappen, omdat de perspectieven van het lager technisch onderwijs goed zijn, terwijl ze bij technische wetenschappen slechts gemiddeld zijn. 
Om deze reden is het opnemen van data met betrekking tot de huidige arbeidsmarktpositie van een opleidingstype van groot belang voor de bruikbaarheid van de prognoses. De verwachte perspectieven moeten immers steeds tegen het licht van de huidige omstandigheden worden bekeken. Een uitzondering op deze regel dat het arbeidsmarktperspectief duidt op de verandering in de omstandigheden zou de werkloosheid kunnen zijn. Omdat werkloosheid gezien kan worden als een uiting van een vertraagde aanpassing bij een aanbodoverschot, valt te verwachten dat het werkloosheidspercentage bij een langdurig gemiddeld arbeidsmarktperspectief uiteindelijk rondom de gemiddelde werkloosheid uit zal komen. Het werkloosheidspercentage zelf, en niet de verandering daarin, zou dan gerelateerd zijn aan de discrepanties tussen vraag en aanbod.

\section{Het niveau van de confrontatie}

Het aanbod van arbeid wordt in het informatiesysteem primair benaderd vanuit opleidingstypen, terwijl de vraag naar arbeid in eerste instantie op het niveau van beroepsklassen plaatvindt. Voor een confrontatie van vraag en aanbod moet echter hetzelfde niveau voor beide grootheden gekozen worden. In de opzet van het informatiesysteem onderwijs-arbeidsmarkt is dit het niveau van de opleidingstypen. De vertaling van vraag per beroepsklasse naar vraag per opleidingstype is echter niet onproblematisch. Terwijl het aanbod duidelijk gerelateerd is aan een bepaald opleidingstype er is immers veel tijd nodig om via omscholing in een ander opleidingstype terecht te komen hoeft de vraag naar arbeid zich lang niet altijd te beperken tot een bepaald opleidingstype. Voor een bepaald beroep komen veelal meerdere opleidingstypen in aanmerking. De een is wellicht geschikter dan de andere, maar er is geen reden hierin een volledige beperking op te leggen. Omgekeerd betekent dit dat personen met een bepaalde opleiding in meerdere beroepen terecht kunnen komen, maar vooral ook dat de banen die in principe open staan voor dit opleidingstype ook beschikbaar zijn voor andere opleidingstypen. Borghans en Heijke (1993) introduceren een model waarin de concurrentie-interactie tussen de opleidingstypen expliciet wordt gemaakt. In Borghans (1992) en Van der Velden en Borghans (1993) wordt de concurrentiepositie van opleidingstypen nader in beeld gebracht ${ }^{3}$.

Het is overigens ook mogelijk de confrontatie tussen vraag en aanbod plaats te laten vinden op het niveau van beroepsklassen. Het aanbod van opleidingstypen zou dan vertaald moeten worden in aanbod per beroepsklasse. De hieruit af te leiden discrepantie tussen vraag en aanbod geeft dan aan - vergelijkbaar met de discrepantie bij opleidingen - hoe de wervingsproblematiek voor bepaalde beroepen zich zal ontwikkelen. De reden dat in het informatiesysteem is gekozen voor een confrontatie op het niveau van opleidingstypen is dat dit voor de studie de meest relevante dimensie is. Om de prognoses van het informatiesysteem ook te belichten vanuit de optiek van de vraagzijde van de arbeidsmarkt zou het echter zinvol zijn naast de confrontatie van opleidingstypen ook een confrontatie van beroepsklassen op te stellen.

3. Vergelijkbare gegevens zijn ook verschenen in het rapport over de inpassing van gegevens uit schoolverlatersenquêtes in het informatiesysteem (Wieling, De Grip en Van der Velden, 1993). 


\section{Baanconcurrentie}

Hierboven werd reeds aangegeven dat het voor de bepaling van het arbeidsmarktperspectief van opleidingstypen van belang is te weten welke opleidingen met elkaar concurreren om dezelfde banen. Daarnaast is, om de verwachting van het arbeidsmarktperspectief te kunnen toespitsen op schoolverlaters, vereist dat er een afbakening gemaakt wordt van de banen waarvoor schoolverlaters in aanmerking komen. Tevens dient bepaald te worden wie er met de schoolverlaters om deze banen concurreren. Door het specifieke segment van vraag en aanbod af te bakenen kan een verhouding tussen beide worden bepaald.

Bij de prognoses voor 1992 is de veronderstelling gehanteerd dat schoolverlaters in aanmerking komen voor de nieuwe banen (uitbreidingsvraag) en de vrijkomende banen door vertrek van reeds werkzame personen met dezelfde opleiding of hetzelfde beroep (vervangingsvraag). Verder wordt verondersteld dat zij bij het bemachtigen van deze banen geen concurrentie van andere werkzoekenden ondervinden. Dit impliceert dat ervan uit wordt gegaan dat mensen die reeds een baan hebben hieruit niet door studenten weggeconcurreerd kunnen worden. Als de reeds werkzame personen proberen een nieuwe baan te krijgen hebben nieuwkomers hier in principe geen last van, omdat deze mobiliteit per saldo geen verlies aan baanopeningen betekent. Als echter een werkende noodgedwongen uit moet kijken naar een andere baan heeft deze, volgens de gemaakte veronderstelling, meer kans dan de nieuwkomers, voor wie immers alleen de netto-toename van banen overblijft. Verder vindt aan de aanbodkant geen concurrentie met andere groepen plaats. Dit houdt in dat werklozen en herintreders kennelijk geen concurrentie vormen voor de schoolverlaters.

Sinds de prognoses van 1990 wordt aan de aanbodkant ook rekening gehouden met de concurrentie van werklozen. Verondersteld is dat alleen degenen die korter dan een jaar werkloos zijn een serieuze bedreiging vormen van de positie van schoolverlaters.

\subsection{De data}

Voor het opstellen van de prognoses ten behoeve van het informatiesysteem, en voor de bijbehorende actuele data en indicatoren zijn een drietal databronnen van groot belang. Dit zijn de Arbeidskrachtentelling (AKT) van het Centraal Bureau voor de Statistiek (CBS), de leerlingramingen van onder andere het Ministerie van Onderwijs en Wetenschappen en gegevens van de Arbeidsvoorzieningsorganisatie met betrekking tot de geregistreerde werklozen. Deze drie databronnen worden in deze paragraaf ieder afzonderlijk besproken. Daarnaast werden van het CPB ook nog de werkgelegenheidsprognoses per bedrijfssector en enkele andere exogene variabelen gebruikt. De CPB-gegevens zullen echter aan de orde komen bij de empirische evaluatie (in hoofstuk 4).

\section{Arbeidskrachtentelling en Enquête Beroepsbevolking}

Voor het vraaggedeelte van het informatiesysteem is de voornaamste bron van data de AKT van het CBS geweest, inmiddels opgevolgd door de Enquête Beroepsbevolking (EBB). Op basis van de 
AKT zijn gegevens bekend over de aantallen werkzame personen per bedrijfssector, beroepsklasse en opleidingstype. Deze gegevens zijn gebruikt om de verdeling van de vraag per bedrijfstak over beroepsklassen en opleidingstypen te voorspellen. Een belangrijk aspect met betrekking tot de bij de prognose en evaluatie daarvan gebruikte data, is de continuiteit van de databronnen.

Bij het opstellen van de prognoses waren de AKT's van 1979, 1981, 1983 en 1985 beschikbaar. Versies van de AKT van voor 1979 waren niet bruikbaar omdat ze gebaseerd waren op een afwijkende onderwijsclassificatie. De prognoses moesten derhalve gebaseerd worden op slechts vier historische waarnemingen. Inmiddels zijn ook de jaarlijkse EBB-gegevens beschikbaar vanaf 1988 voor bedrijfssectoren en beroepsklassen en vanaf 1990 voor de opleidingstypen. De opzet van de EBB wijkt echter af van de opzet van de AKT zodat de combinatie van beide bestanden niet probleemloos verliep ${ }^{4}$. De voornaamste veranderingen betreffen een wijziging van de definitie van werkzame personen, die met name voor de kleinere banen grote consequenties heeft. Daarnaast heeft er een aanpassing plaatsgevonden van de wijze waarop onderdelen van bedrijven in de bedrijfssectorindeling worden opgenomen.

Voor de prognoses met behulp van zowel AKT- als EBB-data zijn vooral de veranderingen met betrekking tot de ondergrens voor het aantal gewerkte uren bij de definitie van de werkzame bevolking van belang. In de AKT werd gevraagd of mensen betaald werk hadden zonder hierbij een expliciete ondergrens te geven voor het minimum aantal uren dat werd gewerkt. In de EBB wordt wel expliciet de link gelegd met het gewerkte aantal uren. Op basis van deze gegevens telt het CBS voortaan iedereen als werkend die minstens 12 uren per week betaald werk verricht. Uit de informatie kan echter ook het aantal werkenden met minstens 1 uur werk per week afgeleid worden. In principe zou deze laatste definitie overeen moeten komen met de impliciet in de AKT gehanteerde definitie, maar door de andere wijze van vragen is er bij de AKT een groot aantal mensen met kleine banen niet als werkzaam persoon geregistreerd (Bierings, Imbens en Van Bochove, 1990). Hierdoor zijn de AKT- en EBB-gegevens niet direct tot elkaar te herleiden.

Ondanks de veranderingen in opzet blijkt de EBB redelijk goed koppelbaar te zijn aan de AKT, zodat er voor de prognoses die recentelijk zijn opgesteld voor 1998 bij de beroepsklassen 8 en voor de opleidingstypen 6 waarnemingsmomenten beschikbaar waren. Omdat het CBS binnenkort overstapt op een nieuwe beroepenindeling is het nog onduidelijk of de AKT's beschikbaar blijven voor het onderzoek. Het zal wellicht onmogelijk zijn de AKT's te hercoderen op basis van de nieuwe beroepenindeling. Hierdoor zou de beschikbare tijdreeks weer aanzienlijk verkort worden.

Overigens hebben sinds het verschijnen van de eerste prognoses in 1989 al een aantal classificatieveranderingen plaatgevonden. De classificaties voor bedrijfssectoren, beroepsklassen, en onderwijstypen, waarop de prognoses betrekking hadden zijn gebaseerd op classificaties die gangbaar waren bij de leveranciers van de desbetreffende data. Voor de bedrijfssectoren betrof dit de indeling van bedrijfssectoren zoals het CPB die hanteerde bij haar middellange-termijn-ramingen. In 1989 werd een indeling in 22 bedrijfssectoren gebruikt. Sinds 1990 gebruikt het ROA in

4. Problemen met betrekking tot deze koppeling worden besproken in Dekker en De Grip (1993). 
navolging van het Athena-model van het CPB, een indeling in 14 bedrijfssectoren. Deze indeling heeft sindsdien nog enkele kleine veranderingen ondergaan.

Bij de beroepenindeling heeft het ROA zelf besloten de destijds gebruikte, sterk verouderde, indeling in CBS-beroepsklassen te laten vallen. Er werd geconstateerd dat de CBS-classificatie onvoldoende geschikt was voor een beschrijving van de arbeidsmarktprocessen op dit lage niveau van aggregatie. De heterogeniteit van de bestaande beroepsklassen met betrekking tot de opleidingsachtergrond van de werkenden was te groot. Bovendien schoot de herkenbaarheid van de CBS-beroepsklassen voor de gebruikers van de ROA-informatie tekort. Er is daarom een nieuwe classificatie gemaakt, waarbij CBS-beroepsgroepen zijn geclusterd op basis van het opleidingsprofiel van degenen die in de desbetreffende beroepsgroep werkzaam zijn ${ }^{5}$.

De classificatie van opleidingen die is gehanteerd bij de geëvalueerde prognoses is een aggregatie van opleidingscategorieën uit de Standaard Onderwijs Indeling van het CBS op 3-digit niveau. Deze classificatie is tot op heden grotendeels gehandhaafd gebleven, maar heeft op bepaalde punten kleine veranderingen ondergaan op grond van de problemen die de indeling in de praktijk met zich meebracht. Deze veranderingen in de gehanteerde classificaties zijn echter altijd zodanig opgesteld dat het mogelijk bleef alle beschikbare jaargangen van de AKT en de EBB te blijven gebruiken. Ook bij eventuele nieuwe veranderingen blijft deze omzetbaarheid een belangrijk punt.

Een tweede aspect dat van groot belang is bij de gebruikte data, is de kwaliteit van de databronnen. Omdat zowel de AKT als EBB steekproeven onder de Nederlandse beroepsbevolking zijn, bevatten beide een steekproeffout. Verder zullen er door fouten in de steekproeftrekking, en de verwerking van de enquêtes nog extra fouten optreden die de kwaliteit verminderen. Doordat de EBB gebaseerd is op een steekproef van 1,1\%, terwijl de AKT doorgaans op $3 \%$ van de bevolking was gebaseerd is de steekproeffout aanzienlijk toegenomen. Bovendien worden sinds enige tijd door het CBS alleen nog data verstrekt die afgerond zijn op duizendtallen bij gegevens die gepubliceerd worden en vijfhonderdtallen bij databestanden die voor onderzoekdoeleinden worden gebruikt. Dit vergroot de foutenmarge van de data.

Overigens moet opgemerkt worden dat de EBB in tegenstelling tot de AKT jaarlijks verschijnt, zodat de hoeveelheid beschikbare informatie per jaar slechts licht is gedaald. Zeker voor de betrouwbaarheid van tijdreeksanalyses zal de voorkeur daardoor uitgaan naar de jaarlijkse EBB-data. Met name als de data binnen een statistische analyse in hun onderling verband (tijdreeks of crosssectie) worden beschouwd zijn de fouten in de data aanvaardbaar. Bij het modelleren moet echter, meer dan nu het geval is, expliciet met deze meetfouten rekening worden gehouden, om zo te voorkomen dat de meetfouten de resultaten gaan domineren. Verder levert de gewoonte om voor onderzoeksdoeleinden cijfers af te ronden op vijfhonderdtallen een onnodige verslechtering van de kwaliteit op bij het gebruik van de gegevens als onderzoeksbestand. Het zou de voorkeur verdienen als data die voor analyses worden gebruikt zonder afronding beschikbaar zouden kunnen worden

5. De Grip, Groot en Heijke (1987) bevat de eerste analyses die ten grondslag liggen aan deze nieuwe indeling die definitief tot stand kwam in Dekker, De Grip en Van de Loo (1990). In Dekker en De Grip (1992) wordt een vergelijking gemaakt tussen de CBS- en de ROA-beroepenclassificatie. 
gesteld, terwijl de gepubliceerde cijfers in dat geval wel zouden kunnen worden afgerond.

Naast de stelregel van het CBS om de beschikbare data af te ronden wordt ook als regel gehanteerd dat er geen cijfers beschikbaar worden gesteld die betrekking hebben op minder dan 5.000 personen. Voor interne onderzoeksdoeleinden ligt deze grens op 2.500. Bij het gebruik van driejaarsgemiddelden wordt de ondergrens voor te publiceren cijfers verlaagd tot 2.000 . Hoewel bij gebruik van zulke drie-jaars-gemiddelden voor onderzoeksdoeleinden informatieverlies optreedt kan dit voor kleine beroepen en opleidingen een geschikt alternatief zijn voor het gebruik van de EBB bij de actuele data.

\section{Uitstroomdata}

De gegevens met betrekking tot de uitstroom van schoolverlaters, die gebruikt worden als een prognose van het nieuwe aanbod op de arbeidsmarkt zijn in de eerste plaats gebaseerd op de leerlingenramingen zoals die gehanteerd worden door het Ministerie van Onderwijs en Wetenschappen. In 1989 betrof dit Worsa, voor het wetenschappelijk onderwijs, Rhobos, voor het HBO, en Skill, voor het gehele reguliere onderwijs. Inmiddels zijn de drie prognosemodellen vervangen door de Referentieraming die het gehele reguliere onderwijs beslaat. Deze ramingen zijn gebaseerd op data uit de integrale leerlingentellingen van het CBS. Omdat de aanbodprognoses van het informatiesysteem echter rechtstreeks gebaseerd zijn op de onderwijsramingen, vormen deze geen directe bron voor het informatiesysteem.

Naast de ramingen voor het reguliere voltijdse onderwijs worden er nog talloze informatiebronnen gehanteerd voor niet-reguliere onderdelen van het onderwijs. Dit betreft onder andere gegevens over erkend schriftelijk onderwijs, bedrijfsopleidingen en scholingsmaatregelen van de Arbeidsvoorzieningsorganisatie. Ook voor het deeltijdonderwijs moeten aparte bronnen worden gehanteerd. De informatie uit deze bronnen is vaak slecht toegankelijk, onbetrouwbaar en geclassificeerd op een wijze niet niet binnen de CBS-classificaties past. Bovendien bestaat er bij gebruik van meerdere databronnen het gevaar van dubbeltellingen. Het zou daarom een verbetering betekenen als leerlingcijfers over het niet-reguliere onderwijs, net als voor het reguliere onderwijs, op een geïntegreerde wijze zou worden verzameld en gepubliceerd.

\section{Werkloosheidsdata}

De actuele data in het informatiesysteem bevatten ook gegevens over de werkloosheid per opleidingstype. Deze zijn gebaseerd op de door Arbeidsvoorzieningsorganisatie geregistreerde werkloosheid. Op basis van het bestand van half april 1987 is een telling gemaakt van de werklozen. Inmiddels zijn, vanwege de decentralisatie van de Arbeidsvoorzieningsorganisatie, geen cijfers over de werkloosheid meer beschikbaar uit deze bron.

In plaats van deze cijfers met betrekking tot geregistreerde werkloosheid wordt thans gebruik gemaakt van de werkloosheidscijfers uit de schoolverlatersenquêtes, de HBO-monitor en RUBS. Deze databronnen geven echter alleen informatie over de werkloosheid onder schoolverlaters en 
zijn bovendien niet beschikbaar voor de WO-opleidingen en het basisonderwijs. Zowel om goede actuele informatie over de werkloosheid te kunnen verstrekken, maar ook om bij de verdere ontwikkeling van de gehanteerde prognosesmethodiek expliciet werkloosheid te kunnen modelleren is een goede bron voor werkloosheidscijfers over de volle breedte van de arbeidsmarkt echter van groot belang.

\subsection{Uitbreidingsvraag per beroep}

Zoals in paragraaf 2.2. over de algehele opzet van de prognoses reeds is opgemerkt, vormen de prognoses van het CPB met betrekking tot de werkgelegenheid per bedrijfssector de invoer voor het prognosemodel voor de uitbreidingsvraag. In eerste instantie worden deze werkgelegenheidsprognoses per bedrijfssector omgezet naar werkgelegenheidsprognoses per beroepsklasse. Deze omzetting bevat ook een omzetting van de werkgelegenheid gemeten in arbeidsjaren naar de werkgelegenheid in personen, op grond van de door het CPB voorspelde P/A-ratio's (personen/arbeidsjaren ratio's) per bedrijfssector.

De prognoses van de werkgelegenheid per beroepsklasse (Dekker, De Grip en Heijke, 1988) worden volledig bepaald door de bedrijfsectorspecifieke vraagfactoren. Ontwikkelingen aan de aanbodzijde van de arbeidsmarkt spelen daarbij geen rechtstreekse rol. In de prognoses van het CPB wordt echter de vraag naar arbeid op macroniveau mede bepaald door aanbodfactoren. Ten eerste beïnvloedt het aanbod rechtstreeks de totale vraag en ten tweede is het aanbod van invloed op de lonen die op hun beurt weer consequenties hebben voor de vraag $^{6}$. Deze opzet van het model betekent dat vraag op beroepsklasseniveau, afgezien van de invloeden op macroniveau, geïnterpreteerd moet worden als de ex ante vraag, dat wil zeggen als de vraag zoals die er zou zijn geweest bij gelijkblijvende schaarsteverhoudingen op de arbeidsmarkt. Een andere interpretatiemogelijkheid van de gevolgde aanpak is dat verondersteld is dat de vraag op beroepsklasseniveau eenvoudigweg niet beïnvloed wordt door aanbodfactoren. Dat wil zeggen dat de vraag per beroepsklasse voor de werkgevers vaststaat en zij hoogstens als gevolg van schaarsteverhoudingen op de arbeidsmarkt besluiten om veranderingen aan te brengen in het type arbeidskracht dat dit beroep gaat uitoefenen. Met andere woorden: de organisatiestructuur wordt niet aangepast aan de schaarsteverhoudingen op de arbeidsmarkt. Alleen de opleidingsachtergrond van de personen die deze werkzaamheden uitvoeren kan variëren. De interactie tussen vraag en aanbod komt dan pas tot stand in het opleidingenmodel.

Hoewel de publicaties over de opzet van het informatiesysteem in 1989 niet expliciet waren op dit punt wordt er bij deze evaluatie vanuit gegaan dat inderdaad impliciet de veronderstelling gemaakt is dat de vraag per beroepsklasse onafhankelijk is van aanbodfactoren en dat op dit niveau de vraag ex post - dat wil zeggen nadat aanpassingen vanwege de schaarsteverhoudingen hebben plaatsgevonden - dus gelijk is aan de vraag ex ante. Deze veronderstelling is te meer aannemelijk daar bij de opleidingstypen wel expliciet melding gedaan wordt van dit onderscheid en nadrukkelijk

6. Zie bijvoorbeeld het schema in CPB (1990, pagina 4) voor het Athena-model of het schema in Eijgenraam en Verkade (1988, pagina 4) voor het destijds gebruikte Beta-model. 
gesteld wordt dat de ex post vraag kan afwijken van de prognoses vanwege de aanpassingsprocessen die op de arbeidsmarkt plaatsvinden.

Voor de evaluatie is het onderscheid tussen ex ante en ex post vraag zeer wezenlijk omdat bij een ex ante vraag niet zonder meer een vergelijking kan worden gemaakt tussen de voorspelde en de gerealiseerde vraag. In de ex-post-interpretatie van vraag is dit wel het geval maar dit houdt wel in dat er twee belangrijke aannames worden gemaakt. Ten eerste wordt verondersteld dat werkgevers niet op grond van de schaarsteverhoudingen gaan substitueren tussen de verschillende beroepsactiviteiten, zodat de vraag per beroepsklasse ongewijzigd blijft. Ten tweede wordt verondersteld dat, hoewel werkgevers bij het invullen van vacatures bij bepaalde beroepen een voorkeur voor bepaalde opleidingstypen hebben, zij als ze door de schaarsteverhoudingen worden gedwongen uit te wijken naar andere opleidingstypen, toch evenveel personen in dienst nemen en dus niet de hoeveelheid personen uitbreiden om te compenseren voor de mindere geschiktheid.

\section{Opzet beroepenmodel}

In de omzetting van werkgelegenheidsprognoses per bedrijfssector naar werkgelegenheidsprognoses per beroepsklasse spelen twee componenten een wezenlijke rol. Ten eerste kan men, gegeven de beroepenstructuur van iedere bedrijfssector in het verleden, komen tot een prognose van de werkgelegenheid per beroep door eenvoudigweg de gevolgen van de veranderende werkgelegenheid per bedrijfssector door te rekenen. Deze aanpak wordt het vaste-coëfficiëntenmodel genoemd. Modellen op basis van louter vaste coëfficiënten worden vaak toegepast, bijvoorbeeld door het Bureau of Labor Statistics (BLS) in de Verenigde Staten ${ }^{7}$. Deze methode is echter onvoldoende in staat veranderingen door de technologische ontwikkeling te voorspellen, omdat ervan wordt uitgegaan dat de bestaande beroepenstructuur van sectoren ongewijzigd blijft. Bishop en Carter (1991) laten zien dat het BLS mede als gevolg daarvan de groei in bepaalde beroepen onvoldoende weet te voorspellen.

Om beter te kunnen voorspellen dan alleen op basis van deze vaste-coëfficiënten-methode is een verklarend model van de beroepenstructuur als tweede component vereist. Een dergelijk model is ook toegepast voor de prognoses van het informatiesysteem onderwijs-arbeidsmarkt in 1989. De aandelen van beroepsklassen in de totale werkgelegenheid van een bedrijfssector worden hierbij afhankelijk gemaakt van verklarende variabelen. In het prognosemodel dat in 1989 is gebruikt worden als verklarende variabele naast een trend, de verhouding tussen investeringen en de toegevoegde waarde, de bezettingsgraad en het aandeel automatiseringsdeskundigen (CBSberoepsklasse 08) in de werkgelegenheid gebruikt. Daarnaast bevat het model voor elk beroep in elke bedrijfssector een afzonderlijke constante term, de zogenaamde bedrijfssectorconstante.

Bij het hanteren van een dergelijk model voor de verklaring van de aandelen van beroepsklassen in de totale werkgelegenheid van bedrijfssectoren doet zich in de praktijk een drietal problemen voor.

7. Zie BLS (1988). In Van Eijs (1993) wordt een overzicht gegeven van de historische ontwikkeling van manpower-forecast-methodes; Van Eijs (1994) beschouwt de prognosemethodieken van enkele belangrijke Westerse instituten. 
Het eerste probleem betreft de keuze van de verklarende variabelen. Het tweede probleem betreft de specificatie van de vergelijking die wordt geschat en vervolgens de basis vormt voor de prognose van de beroepenstructuur. Ten derde doen zich problemen voor bij het schatten van de vergelijkingen, vanwege de geringe hoeveelheid data die ter beschikking staan. Op deze drie problemen zal achtereenvolgens worden ingegaan.

\section{Verklarende variabelen}

Ten eerste de keuze van de variabelen. In het beroepenmodel van 1989, maar ook in de latere studies op dit gebied (Peeters, 1990 en Borghans en Heijke, 1994) blijkt steeds weer dat van de verklarende variabelen die worden gebruikt om veranderingen in de beroepenstructuur van opleidingen te voorspellen het grootste deel van de verklarende kracht van de trend afkomstig is. De verklarende variabelen met een inhoudelijk economisch karakter, zoals hierboven genoemd, blijken slechts voor een klein deel de verschuivingen in de beroepenstructuur te kunnen verklaren. Dit heeft als nadeel dat het gehanteerde model slechts in geringe mate een beeld geeft van de oorzaken van de veranderingen in de beroepenstructuur. Een groter nadeel is echter dat bij het uitsluitend hanteren van een trend in de prognosemethodiek altijd het gevaar aanwezig is dat deze trend ten onrechte automatisch wordt doorgetrokken in de prognose, omdat onduidelijk is waardoor de trendmatige ontwikkeling wordt veroorzaakt.

Het vinden van goede verklarende variabelen blijft daarom van groot belang. Dit kan geschieden door aan de ene kant verder uit te zoeken welke factoren waarschijnlijk een belangrijke bijdrage kunnen leveren aan de verklaring van de veranderingen in de beroepenstructuur. Omdat veel mogelijk belangrijke factoren op basis van de beschikbare informatie niet, of slechts zeer indirect in beeld kunnen worden gebracht, kan het ook nodig zijn op zoek te gaan naar additionele databestanden. In de huidige opzet zijn alle verklarende variabelen van het model variabelen op bedrijfssectorniveau. Het beroepenmodel bevat nog geen verklarende variabelen op beroepsklasseniveau.

Voorlopig blijft de trend, zoals gezegd, een belangrijke verklarende variabele in het beroepenmodel. Trendextrapolatie zal ook altijd wel een rol blijven spelen, omdat het niet realistisch is te verwachten dat alle processen die plaatsvinden in de verschuivingen tussen beroepen op grond van een economisch-inhoudelijk model verklaard zullen worden.

De in 1989 opgestelde prognoses waren gebaseerd op een tijdreeks die slechts was opgebouwd uit vier AKT-enquêtes die een periode van 7 jaar beslaan. Inmiddels is er voor de verklaring van de beroepenstructuur reeds een tijdreeks van 13 jaar beschikbaar met 9 waarnemingsmomenten. Door het langer worden van de tijdreeksen treden grote trendmatige verschuivingen over de gehele waarnemingsperiode minder vaak op. Deze vergroting van de tijdreeks biedt uiteraard mogelijkheden voor betere prognoses, maar vraagt aan de andere kant ook om aanpassingen in de wijze waarop met mogelijk tijdelijke trendmatige ontwikkelingen wordt omgegaan. Voorkomen dient te worden dat trends die inmiddels reeds zijn afgevlakt toch nog worden geëxtrapoleerd, of dat trends die zich alleen in de laatste waarnemingsjaren voordoen niet volledig waargenomen worden in de langere 
tijdreeks. Dit betekent dat recente waarnemingen een andere behandeling dienen te krijgen dan waarnemingen die verder in het verleden liggen.

\section{De specificatie}

Een tweede punt dat nadere invulling moet krijgen in een beroepenmodel is de specificatie van de onderlinge verbanden tussen het aandeel van een beroep in de werkgelegenheid van een bedrijfssector en de verklarende variabelen. De gekozen specificatie bepaalt in grote mate op welke wijze de geobserveerde ontwikkelingen worden doorgetrokken naar de toekomst (zie Borghans en Heijke, 1994).

De keuze van de specificatie van het model heeft ook grote consequenties voor de behandeling van met name de laatste waarneming in de beschikbare tijdreeks. In het model uit 1989 werd een regressie van de beroepsaandelen op enkele verklarende variabelen uitgevoerd. Uiteraard wijken de werkelijke aandelen af van de gevonden regressielijn. Door nu de regressielijn te gebruiken voor de prognoses negeert men de informatie die eventueel besloten ligt in het verschil tussen de laatste waarneming en het voor dat jaar geschatte beroepsaandeel. Een afwijking in deze laatste waarneming kan veroorzaakt zijn door toevalligheden, maar kan ook voortkomen uit het feit dat er factoren werkzaam zijn die niet in het model zijn opgenomen. Het ligt zeer voor de hand dat deze factoren ook in de nabije toekomst zullen spelen en dus van belang zijn voor de prognoses. $\mathrm{Er}$ ontstaat hierdoor, vanuit een econometrisch gezichtspunt, autocorrelatie van de storingsterm. In het destijds gehanteerde model werd hier echter geen rekening mee gehouden. Inmiddels hebben er echter veranderingen aan het model plaatsgevonden waardoor dit facet wel in het model is gebracht. In Peeters (1990) wordt als extra verklarende variabele de vertraagde endogene opgenomen en Borghans en Heijke (1994) hebben gekozen voor een groeimodelspecificatie. Bij de beide genoemde specificaties wordt de laatste waarde van het beroepenaandeel als uitgangspunt van de prognose genomen, waardoor dus rekening wordt gehouden met de informatieve waarde van deze laatste observatie. Hierdoor is het ook niet meer nodig afzonderlijke bedrijfssectorconstanten in het model op te nemen. Ook met het oog op het langer worden van de beschikbare tijdreeksen is dit een voordeel. Een vergelijkbare aanpak wordt ook gepropageerd door Clements en Hendry (1993) en Wilson (1993).

\section{Schatten van het model}

Een derde belangrijk punt bij de invulling van een verklarend beroepenmodel is de wijze waarop het model wordt geschat. Doordat de beschikbare tijdreeks nogal kort is, is het niet mogelijk voor ieder beroep afzonderlijk een verklarend model te schatten. Daarom is in het beroepenmodel dat hier wordt geëvalueerd een pooling van beroepen in verschillende bedrijfssectoren gehanteerd. Dit houdt in dat voor een beroep een schatting wordt gemaakt waarbij aan de ontwikkeling van dat beroep in iedere bedrijfssector dezelfde vergelijking wordt opgelegd. Wel zijn hierbij enerzijds de landbouw en industrie-sectoren en anderzijds de tertiaire en kwartaire sector uit elkaar gehouden, vanwege het zeer uiteenlopende karakter van deze twee sectorclusters. Zelfs met een pooling van de data blijken echter een aantal parameters van het model onnauwkeurig geschat te worden. Dit blijkt uit 
de soms extreme parameterschattingen die aangetroffen worden. Blijkbaar domineert in deze schattingen, vanwege het gebrek aan datamateriaal, de schattingsfout in de geschatte parameters. Het gebruik van de schattingen zou tot instabiele voorspellingen leiden. Daarom is in het beroepenmodel dat destijds werd gehanteerd besloten een modelselectie toe te passen. Deze modelselectie vindt plaats tussen drie modelvarianten. De eerste variant is een model met verklarende variabelen en een trend. De tweede variant is een model met alleen verklarende variabelen zonder trend, terwijl de derde variant betrekking heeft op een model zonder verklarend gedeelte, dat wil zeggen het vaste-coëfficienten-model. Voor ieder beroep wordt voor beide deelgroepen van de arbeidsmarkt - landbouw/industrie en tertiair/kwartair - én van deze drie modelvormen gekozen. Voor beroepen die slechts in één bedrijfssector binnen een deelgebied voorkomen is onmiddellijk de variant zonder verklarend gedeelte gekozen. Bij de overige beroepen is eerst gekeken of de waargenomen trend significant en qua teken plausibel is. Is dit niet het geval dan komt deze trend te vervallen. Vervolgens is gekeken of het verklarende gedeelte van het model in zijn totaliteit significant is. Als dit ook niet het geval is, is teruggevallen op een model zonder verklarende variabelen.

Een consequentie van dit selectieproces is dat - zowel bij landbouw/industrie als bij tertiair/kwartair - in slechts tien gevallen bij de prognoses een trend-term is opgenomen. Dit lijkt in tegenspraak met Bishop en Carter (1991) die het grote belang van trends voor goede beroepenprognoses benadrukken. De vraag is echter of het wel opnemen van de trend in alle gevallen wenselijk zou zijn geweest. Door de zeer korte tijdreeksen die beschikbaar waren, zou de kwaliteit van de trendprognoses waarschijnlijk laag zijn geweest, zodat de kans groot was geweest dat deze schattingen slechte voorspellingen zouden hebben opgeleverd. Overigens is inmiddels het dilemma tussen het al dan niet opnemen van een trend verdwenen doordat de beschikbare tijdreeks langer is geworden maar verder ook omdat er een 'random coefficients'-model in gebruik is genomen dat een middenweg volgt tussen het wel of geen trend opnemen. Afhankelijk van de betrouwbaarheid van de schattingen wordt, in deze nieuwe aanpak, een gewogen combinatie genomen van de prognoses op basis van de variant met en de variant zonder trend. Deze aanpak voorkomt de alles-of-niets-strategie, waarbij bij twijfels over de betrouwbaarheid van de trend onmiddellijk geen trend meer kon worden opgenomen. Ook hoeven bij deze aanpak de parameters van verschillende beroepen of verschillende bedrijfssectoren niet aan elkaar gelijk te zijn. $\mathrm{Er}$ is daardoor meer mogelijkheid voor variatie tussen beroepsklassen en bedrijfssectoren.

\section{Conclusies}

Samenvattend heeft het beroepenmodel dat in 1989 is gehanteerd, afgezien van de fundamentele aannames over de aard van de vraag op beroepsniveau, twee mogelijke tekortkomingen. Ten eerste wordt weinig gebruik gemaakt van de informatie die ligt besloten in de laatste waarneming en ten tweede is er door de gehanteerde modelselectie, deels noodgedwongen, slechts enkele keren een specificatie met een trendterm gekozen. 


\subsection{Vervangingsvraag per beroep}

Omdat de prognoses binnen het informatiesysteem in de eerste plaats bedoeld zijn om de arbeidsmarktperspectieven van schoolverlaters te schetsen speelt naast de werkgelegenheidsontwikkeling ook de vervangingsvraag een belangrijke rol. Zoals in paragraaf 2.2 werd opgemerkt valt immers te verwachten dat de reeds werkzame personen doorgaans hun banen kunnen behouden of vanwege hun ervaring eerder in aanmerking komen voor nieuwe banen. De mogelijkheden voor de nieuwkomers beperken zich daarom tot het netto aantal nieuwe banen en de vacatures die ontstaan door het vertrek van anderen. Het gaat hierbij dus niet om het verloop op zich, maar om de vervangingsvraag - het aantal banen dat beschikbaar komt vanwege het verloop ${ }^{8}$.

Omdat deze vervangingsvraag een zeer groot aandeel kan hebben in het totaal aantal baanopeningen zijn in de prognoses zowel de uitbreidingsvraag als de vervangingsvraag als component van de vraag voor nieuwkomers opgenomen. Toentertijd is de vervangingsvraag op een betrekkelijk eenvoudige wijze voorspeld. Later is de destijds gehanteerde opzet systematisch uitgewerkt en verbeterd (Willems en De Grip, 1990 en De Grip en Willems, 1992). Inmiddels hanteerd ook het Bureau of Labor Statistics (BLS, 1992) vervangingsvraagprognoses. Ook in OSA (1993) wordt gesteld dat de vervangingsvraag een zeer belangrijke component is bij het opstellen van een prognose van de toekomstige arbeidsmarktsituatie. De auteurs schrijven dit belang toe aan de absolute omvang van deze component. Borghans (1991) geeft echter aan dat dit argument niet juist is. De relevantie voor prognoses wordt niet zozeer bepaald door de absolute omvang van de afzonderlijke componenten, maar vooral door de veranderlijkheid van de grootheid. Als de vervangingsvraag groot was maar vrij onveranderlijk, dan zouden de toekomstige arbeidsmarktperspectieven ook niet beïnvloed worden door dit cijfer. Het blijkt echter dat, in ieder geval voor de in Borghans (1991) onderzochte groep onderwijzers, ook de veranderlijkheid van de vervangingsvraag substantieel is.

\section{Het meten van vervangingsvraag}

Bij het opstellen van de vervangingsvraagprognoses moet allereerst de feitelijke vervangingsvraag over een recente periode vastgesteld worden. Pas op basis van een dergelijke meting kan de toekomstige vervangingsvraag per beroepsklasse zinvol voorspeld worden. Voor het adequaat meten van de vervangingsvraag in een historische periode zijn in principe panel-data vereist, waaruit af te leiden is welke personen in een bepaalde periode van beroepsklasse zijn veranderd. De panelbestanden die voorhanden zijn, zijn echter te klein van omvang om op het aggregatieniveau dat gehanteerd wordt voor het informatiesysteem zinvolle uitspraken te kunnen doen ${ }^{9}$. Voor de

8. Deze definitie van vervangingsvraag wordt niet altijd gehanteerd. Soms (bijvoorbeeld door het CBS, 1950) wordt de vervangingsvraag gelijkgesteld aan het verloop.

9. Paneldata hebben voor het meten van beroepsmobiliteit overigens als nadeel dat er doorgaans veel meer mobiliteit wordt waargenomen dan feitelijk plaatsvindt, door veranderingen in de beroepsnaamgeving door individuen en fouten in de classificatie (zie BLS, 1992, en Glebbeek, 1993). Bij geaggregeerde data vallen deze fouten waarschijnlijk toch grotendeels tegen elkaar weg. Waarschijnlijk is het voor dit doel zinvoller gewone cross-sectie-data te gebruiken waarin een retrospectieve vraag over het beroep in het 
vervangingsvraagprognoses in het informatiesysteem is men daarom aangewezen op de standcijfers van de AKT en de EBB.

De prognoses van de vervangingsvraag per beroepsklasse zijn gebaseerd op een vergelijking van de leeftijdsopbouw van de werkzame personen per beroepsklasse tussen de AKT 1979 en 1985. Door de bevolking op te delen in cohorten van 5 jaar, zal na een periode van 5 jaar iedereen één leeftijdsgroep zijn opgeschoven. Door over de cohorten te aggregeren kan daardoor per beroepsklasse bij benadering de relatieve in- en uitstroom worden vastgesteld. Omdat cohortomvang en de meetperiode niet volledig overeenkomen (de duur tussen beide AKT's is zes jaar) is een correctie gemaakt op deze methode, die echter de essentie van de methode niet aantast.

Een nadeel van deze meetmethode is echter dat er per cohort alleen netto-effecten worden waargenomen. Als binnen een cohort zowel personen een beroepsklasse verlaten alsook personen de beroepsklasse binnenstromen wordt feitelijk slechts het saldo van de in- en uitstroom waargenomen. Dit probleem is (gedeeltelijk) ondervangen door de werkenden in een beroepsklasse te splitsen naar leeftijd en geslacht. Met andere woorden, er is geprobeerd de werkzame personen zoveel mogelijk in te delen in homogene groepen waarbinnen of alleen uitstroom plaatsvindt, of alleen instroom. Voor de mannen is deze oplossing waarschijnlijk voldoende nauwkeurig, omdat hier vaak de in- en uitstroom van een bepaalde beroepsklasse op specifieke leeftijden plaatsvindt. Een uitzondering daarbij is vaak de groep jongeren die de eerste jaren na hun intrede op de arbeidsmarkt nogal eens van beroep veranderen. Voor vrouwen kunnen er echter problemen ontstaan als gevolg van de herintreding. Als in de leeftijdscategorieën waarin sommige vrouwen herintreden andere vrouwen hun beroepsklasse verlaten zal een gedeelte van de uitstroom of een gedeelte van de instroom niet worden waargenomen. Om dit probleem te verhelpen zou de vrouwelijke populatie verder opgesplitst moeten worden in een deel dat voornamelijk instroomt en een deel dat voornamelijk uitstroomt. Het zal echter vrijwel onmogelijk zijn kenmerken te vinden die voldoende tussen beide groepen discrimineren. Als alternatief zou gebruik gemaakt kunnen worden van de informatie die in de EBB beschikbaar is op grond van de retrospectieve vraag naar de belangrijkste activiteit in het voorgaande jaar.

Een probleem dat zich voordoet bij het verkleinen van de onderscheiden groepen, om zo tot een goede bepaling van de in- en uitstroom te komen, is dat de gebruikte data door de geringere celvulling steeds minder betrouwbaar worden, waardoor steekproeffouten de prognoses gaan domineren. Het is echter moeilijk het effect hiervan precies aan te geven. Bij het verder uitbreiden van het aantal onderscheiden groepen zal dit verstorende element echter in de analyse betrokken moeten worden. Er zijn statistische methoden die deze toenemende verstoring op een adequate wijze kunnen ondervangen. Hierbij kan bijvoorbeeld gedacht worden aan het ook bij de uitbreidingsvraag gehanteerde 'random coefficient'-model. Bij de empirische evaluatie kunnen deze problemen echter niet geobserveerd worden doordat de feitelijke vervangingsvraag alleen met behulp van dezelfde methode kan worden bepaald. De empirische evaluatie beperkt zich derhalve tot het 
prognose-aspect van de vervangingsvraag.

De hierboven beschreven aanpak leidt in eerste instantie tot het bepalen van het verloop binnen een beroepsklasse. Voor nieuwkomers op de arbeidsmarkt is dit verloop echter alleen relevant indien het leidt tot nieuwe vacatures. Omdat ook de uitbreidingsvraag een netto-grootheid is geldt per definitie dat in geval van een groeiende werkgelegenheid de vervangingsvraag gelijk is aan het verloop. Als de werkgelegenheid krimpt, zijn er meer uitstromers dan instromers. Dit verschil is ook per definitie gelijk aan de (negatieve) uitbreidingsvraag. Het verband tussen vervangingsvraag en uitstroom ligt dus, bij een gegeven uitbreidingsvraag, vast. Er geldt:

vervangingsvraag $=$ uitstroom $+\operatorname{MIN}\{$ uitbreidingsvraag, 0$\}$

Op basis van deze identiteit kan het aantal baanopeningen op twee manieren worden vastgesteld. Ten eerste kan men uitgaan van de uitstroom en deze salderen met de uitbreidingsvraag:

baanopeningen $=$ uitstroom + uitbreidingsvraag

De tweede mogelijkheid is uit te gaan van de vervangingsvraag en hierbij indien er sprake is van een groeiende werkgelegenheid, de uitbreidingsvraag op tellen:

baanopeningen $=$ vervangingsvraag $+\operatorname{MAX}\{$ uitbreidingsvraag, 0$\}$

Substitutie van de definitie van vervangingsvraag in de laatste vergelijking laat zien dat beide aanpakken gelijkwaardig zijn. De definitie op basis van de vervangingsvraag laat bovendien zien dat het aantal baanopeningen nooit negatief kan zijn.

\section{Het voorspellen van vervangingingsvraag}

Omdat beide definities equivalent zijn, is het op zich niet wezenlijk op welke wijze het aantal baanopeningen wordt berekend. De huidige aanpak waarbij de vervangingsvraag en de positieve component van de uitbreidingsvraag worden gesommeerd, is waarschijnlijk wel inzichtelijker, omdat het meer voor de hand ligt te stellen dat het aantal baanopeningen laag is, doordat vrijkomende banen niet worden opgevuld dan te poneren dat het aantal baanopeningen vanwege het verloop wordt teniet gedaan door een krimp in de werkgelegenheid.

Bij het opstellen van prognoses wordt het onderscheid tussen beide opsplitsingen echter wel relevant. In de vervangingsvraagprognoses die hier worden geëvalueerd, werd het aantal baanopeningen bepaald op basis van de uitstroom. In het verlengde hiervan heeft ook bij het opstellen van de prognoses een extrapolatie van deze uitstroom plaatsgevonden. Dat wil zeggen dat op basis van de uitstroomcoëfficiënten zoals die zijn waargenomen in de periode 1979-1985 de uitstroom voor de periode 1985-1992 is berekend. Daarbij werd genegeerd dat deze uitstroomcijfers afhangen van de werkgelegenheidsontwikkeling. Er heeft alleen per leeftijdscategorie een correctie plaatgevonden voor de totale werkgelegenheidsontwikkeling. Later is daar 
nog een correctie voor veranderingen in de algehele participatiegraad bij opgenomen. Het beroepsspecifieke element in de werkgelegenheidsontwikkeling is echter buiten beschouwing gelaten.

Deze aanpak kan vanuit twee gezichtspunten worden bekeken. Ten eerste zou de gevolgde aanpak kunnen worden verdedigd door te veronderstellen dat de beroepsspecifieke werkgelegenheidsontwikkeling in de prognoseperiode gelijk is aan die in de observatieperiode. Deze aanname wordt echter vaak geschonden en is inconsistent met de prognoses van de uitbreidingsvraag waarbij uiteraard wel veranderingen in de werkgelegenheidsgroei kunnen voorkomen. Een tweede veronderstelling die bovenstaande aanpak zou kunnen rechtvaardigen is dat de uitstroom onafhankelijk is van de werkgelegenheidsontwikkeling. Een reductie van de werkgelegenheid in een beroepsklasse wordt dan altijd volledig via een verlaagde instroom gerealiseerd. Het is echter niet zonder meer duidelijk dat deze aanname gemaakt kon worden. Bij een sterk krimpende werkgelegenheid in een beroepsklasse - indien de werkgelegenheidskrimp groter is dan de normale instroom - is een dergelijke veronderstelling zelfs onmogelijk. Door uit te gaan van uitstroomcijfers is bij de vervangingsvraagprognoses dus impliciet een veronderstelling gemaakt over de samenhang tussen uitstroom en uitbreidingsvraag. Dit verband wordt weergegeven in figuur 2.1.

Figuur 2.1. Veronderstelde relatie tussen uitbreidingsvraag en uitstroom of vervangingsvraag bij voorspelmethode op basis van uitstroom

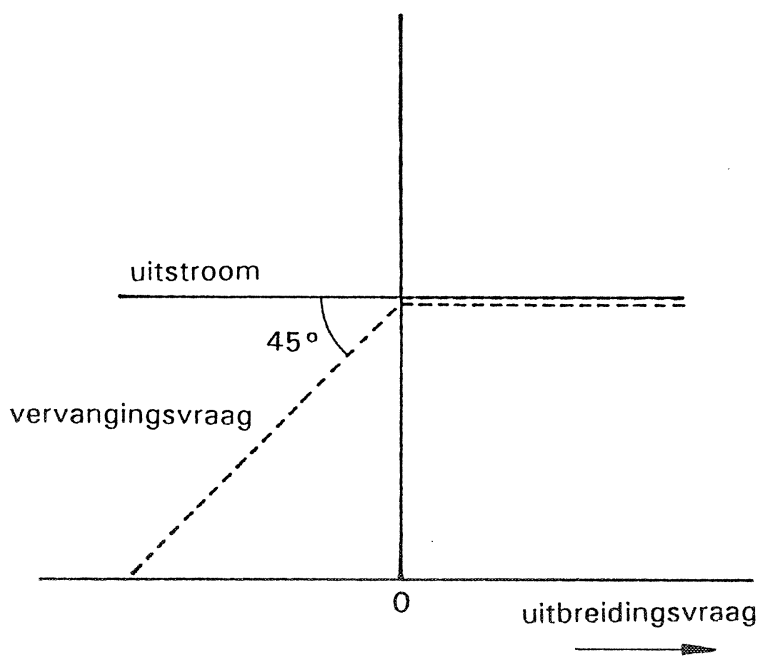

Op grond van Willems en De Grip (1990) is de opzet van de vervangingsvraagprognoses vanaf 1990 veranderd. De baanopeningen werden sindsdien beschreven als de som van de vervangingsvraag en de positieve component van de uitbreidingsvraag. Hiermee werd ook de wijze van voorspellen aangepast aan deze opsplitsing. De uitstroomcoëfficiënten werden weliswaar nog steeds gebruikt voor het doorrekenen van de uitstroomconsequenties van de leeftijdsopbouw per beroepsklasse, maar op basis van deze prognose wordt de vervangingsvraag bepaald onder de veronderstelling dat de uitbreidingsvraag in de prognoseperiode gelijk is aan de uitbreidingsvraag in de observatieperiode. Deze aanpak komt in principe neer op het extrapoleren van de vervangingsvraag. Een voordeel is echter dat vermeden wordt dat bepaald moet worden welke leeftijdsgroep de 
consequenties van de werkgelegenheidsontwikkeling ondervindt. Verondersteld wordt dus dat de vervangingsvraag niet afhangt van de werkgelegenheidsontwikkeling, hetgeen betekent dat de uitstroom wel afhankelijk is van de werkgelegenheidsontwikkeling. De gevolgen van een krimpende werkgelegenheid worden dus volledig gerealiseerd door het vertrek (uit de beroepsklasse) van reeds werkende personen en niet door een beperking van de instroom van nieuwkomers. Het veronderstelde verband tussen vervangingsvraag, uitstroom en uitbreidingsvraag wordt weergeven in figuur 2.2.

Figuur 2.2. Veronderstelde relatie tussen uitbreidingsvraag en uitstroom of vervangingsvraag bij voorspelmethode op basis van vervangingsvraag

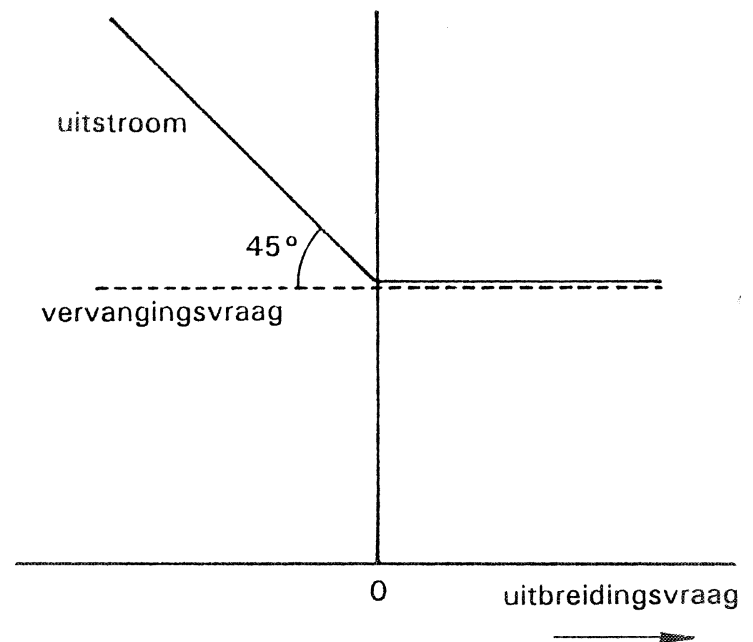

Voor beide hierboven beschreven methoden geldt dat er een bepaalde veronderstelling wordt gemaakt over de relatie tussen uitbreidingsvraag en uitstroom (en daarmee de vervangingsvraag). Een onjuiste specificatie van deze samenhang is voor prognosedoeleinden alleen relevant indien de werkgelegenheidsontwikkeling in een bepaalde beroepsklasse in de prognoseperiode drastisch wijzigt ten opzichte van de werkgelegenheidsontwikkeling in de observatieperiode. Voorspelfouten zullen zich dus met name kunnen voordoen bij deze beroepsklassen. Verwacht kan worden dat er inderdaad een samenhang is tussen uitbreidingsvraag en uitstroom. Bij een teruglopende werkgelegenheid zullen bedrijven immers proberen hun werknemersbestand te reduceren. De keuze tussen oudere werknemers en nieuwkomers zal waarschijnlijk samenhangen met de loonproduktiviteitsverhouding van beide groepen. Ook kan er sprake zijn van een aggregatie-effect. Doordat tegelijkertijd bepaalde ondernemingen failliet gaan en nieuwe bedrijven opgericht worden, maken oudere werknemers indirect plaats voor nieuwkomers.

\section{Conclusies}

Bij het bepalen van de vervangingsvraag per beroepsklasse kunnen al met al drie belangrijke problemen optreden. Ten eerste moet vanwege de aard van de data de in- en uitstroom bepaald worden op basis van standcijfers. Hierdoor kan alleen de netto-methode gebruikt worden. Om 
meetfouten bij deze netto-methode te reduceren moet een adequate onderverdeling van de beroepsbevolking gemaakt worden in groepen waarbinnen of alleen instroom of alleen uitstroom plaatsvindt. Als overigens de meetmethode beter geschikt wordt voor het registreren van instroom in oudere leeftijdsgroepen (herintreders en personen die van beroep veranderen) moet ook de potentiële concurrentie van deze groepen voor het aanbod van schoolverlaters expliciet in de analyse worden betrokken.

Hiermee samenhangend doet er zich een probleem voor met betrekking tot de kwaliteit van de gebruikte data. Doordat de beroepsbevolking onderverdeeld wordt in vele kleine groepen, bestaat het risico dat de steekproeffouten de prognoses gaan domineren. Onderzocht zou kunnen worden wat de relatie is tussen het aantal groepen dat wordt onderscheiden en de meetfout. Bovendien kunnen er statistische methoden ontwikkeld worden die deze fout reduceren. Ook zal de prognose van de vervangingsvraag verbeteren als deze gebaseerd wordt op meer dan één observatieperiode.

Ten derde is het belangrijk meer inzicht te verkrijgen in de gedrag van bedrijven bij uiteenlopende ontwikkelingen in de werkgelegenheid van een beroepsgroep. De vraag is of bij een teruglopende vraag de instroom van nieuwkomers wordt beperkt of dat oudere werknemers versneld uit het beroep zullen stromen. Verwacht kan worden dat een slechte specificatie van dit verband vooral negatieve consequenties heeft voor de prognoses als er een omslag plaatsvindt in de werkgelegenheidsontwikkeling. Op grond hiervan zou het nuttig zijn nader onderzoek te verrichten naar het verloop van de uitstroomcurve.

\subsection{Uitbreidingsvraag per opleidingstype}

De vraag naar arbeid is in het model voor de uitbreidingsvraag, zoals in paragraaf 2.4 werd aangegeven, in eerste instantie als een verbijzondering naar beroepsklassen geformuleerd. De vraag van werkgevers betreft immers primair de behoefte aan het laten vervullen van bepaalde taken c.q. functies. Het aanbod van arbeid wordt echter met name gekenmerkt door de gevolgde opleiding. Om te kunnen komen tot een confrontatie van vraag en aanbod moeten de vraagprognoses per beroepsklasse worden omgezet naar prognoses per opleidingstype, of omgekeerd, de aanbodprognoses vertaald worden naar het aanbod per beroepsklasse. Omdat het primaire doel van het informatiesysteem is om prognoses te maken die bruikbaar zijn voor de studie- en beroepskeuze, ligt een confrontatie van vraag en aanbod per opleidingstype het meest voor de hand.

Het is doorgaans niet zo dat er slechts éen bepaalde opleiding geschikt is voor een bepaald beroep. De Grip en Heijke (1991) laten zien dat het belangrijk is te onderkennen dat voor de invulling van een beroep meerdere opleidingstypen in aanmerking komen. Hier doet zich derhalve het probleem voor dat de vraag naar arbeid per beroepsklasse toegerekend kan worden aan meerdere opleidingstypen. Voor iedere baan kan echter maar één persoon, met één bepaalde opleidingsachtergrond worden aangenomen. In feite is er voor een opleidingstype dus meestal vraag vanuit meerdere beroepsklassen, maar is men bij verschillende beroepsklassen in concurrentie met arbeidskrachten met een andere opleidingsachtergrond. Een zinvolle aanpak om met dit conceptueel probleem om 
te gaan is door de opleidingenstructuur van beroepsklassen te voorspellen op basis van de structuur in het verleden. Deze verdeling hoeft niet constant te zijn, maar kan gerelateerd worden aan verklarende variabelen. Als deze verklaring van de verdeling onafhankelijk is van aanbodfactoren, kan de voorspelde vraag geïnterpreteerd worden als ex ante vraag, dat wil zeggen de vraag zoals die zou zijn geweest als er geen veranderingen in de schaartsteverhoudingen hadden plaatgevonden.

De vergelijking van de ex ante vraag met het aanbod geeft dan, zoals in paragraaf 2.2 werd opgemerkt, een indicatie van de spanning tussen vraag en aanbod. Deze spanning zal aanleiding zijn voor aanpassingsprocessen op de arbeidsmarkt die de positie van schoolverlaters met opleidingen in een overschotsituatie zullen verslechteren en de situatie van schoolverlaters in een tekortsituatie zullen verbeteren. De vraag-aanbod-verhouding geeft dus een indicatie van de te verwachten verslechteringen of verbeteringen van de arbeidsmarktsituatie van schoolverlaters van het desbetreffende opleidingstype.

Ook kan men trachten de aanpassingsprocessen die plaats zullen vinden, binnen het model te verklaren. In dat geval spelen de aanbodelementen wel een rol in de vraag naar opleidingen. Op zich geeft een dergelijk uitgebreid model meer inzicht in het functioneren van de markt, maar het is wel van belang te beseffen dat de aanpassingsprocessen die reeds binnen het model hebben plaatsgevonden ook mogelijk al hebben bijgedragen aan een verslechtering of verbetering van de arbeidsmarktpositie. Vanwege de schaartsteverhoudingen is men immers uitgeweken naar andere banen die kennelijk in het geval van een aanbodoverschot als slechter en in het geval van een tekort als beter worden ervaren. Ook kan de aanpassing in de vraag tot stand zijn gekomen door een verandering van de arbeidsvoorwaarden. Omdat de gehanteerde modellen echter alleen de werkgelegenheid zelf in de analyse betrekken komt de positie die de schoolverlater in zijn baan inneemt niet aan het licht. Derhalve blijft de verhouding tussen ex ante vraag en aanbod een belangrijke indicator van de arbeidsmarktperspectieven van schoolverlaters.

De constatering dat de voorspelde uitbreidingsvraag per beroep ex ante niet gelijk hoeft te zijn aan de feitelijke toekomstige werkgelegenheid per opleidingstype, heeft als consequentie dat het niet zinvol is deze uitbreidingsvraagprognoses op zich empirisch te evalueren. Pas in vergelijking met de aanbodprognoses kan bepaald worden of de ex ante vraag een goede indicator was van de toekomstige arbeidsmarktpositie van schoolverlaters met een bepaalde opleidingsachtergrond.

De prognosemethodiek die toentertijd is gehanteerd (Beekman e.a., 1989), is vergelijkbaar met de gevolgde aanpak bij de uitbreidingsvraag per beroepsklasse. Het model is echter opgebouwd uit twee stappen. Eerst is de werkgelegenheid per opleidingenniveau geschat en vervolgens wordt deze verder verbijzonderd naar opleidingsrichting. In het model wordt de opleidingenstructuur van beroepsklassen, per bedrijfssector geanalyseerd. Inmiddels is een aanpak op een dergelijk laag aggregatieniveau niet meer mogelijk. De door het CBS gehanteerde ondergrenzen bij het beschikbaar stellen van informatie maken het onmogelijk gegevens op dit niveau te gebruiken. Van Eijs en Borghans (1993) laten echter zien dat de opleidingenstructuur van beroepsklassen niet voldoende varieert om een bedrijfssectorspecifieke analyse noodzakelijk te maken. Er kan dus in principe volstaan worden met een analyse van de opleidingenstructuur van beroepsklassen, zonder 
daarbij te verbijzonderen naar bedrijfssector.

Bij de verklaring van de opleidingsniveaus van de werkenden in de verschillende beroepsklassen zijn als verklarende variabelen naast de potentiële beroepsbevolking per opleidingsniveau en de beroepsen sectorconstanten, wederom de beide indicatoren voor de technologische ontwikkeling opgenomen: de investeringen gerelateerd aan de toegevoegde waarde per sector en de automatiseringsgraad per bedrijfssector. Behalve de eerste variabele hebben alle verklarende variabelen alleen een bedrijfssectordimensie en zijn derhalve niet meer bruikbaar als de bedrijfssectorinformatie niet meer kan worden gehanteerd. Het is echter moeilijk om relevante verklarende variabelen te vinden op beroepsklasseniveau. De meestbelovende wijze om een opleidingenmodel verdere economische inhoud te geven is waarschijnlijk het verder in het model betrekken van de onderlinge concurrentie tussen opleidingen (zie Borghans en Heijke, 1993 en Van Eijs, 1994). Hierdoor kunnen substitutie- en verdringingsprocessen in de analyse worden betrokken.

Door het opnemen van de potentiële beroepsbevolking per opleidingsniveau als verklarende variabele in de werkgelegenheidsvergelijking bevat het model, op de manier die eerder al werd aangegeven, al een gedeeltelijke aanpassing van de vraag aan het aanbod. Deze aanpak heeft als nadeel dat daarmee een gedeelte van de aanpassingen van de arbeidsmarktpositie van schoolverlaters die het gevolg zijn van het allocatieproces op de arbeidsmarkt, verloren gaan voor de spanningsindicator. Een voordeel is echter de duidelijk stabiliserende invloed die deze indicator van de mogelijke verdringingskracht van het desbetreffende opleidingstype op de prognoses van de arbeidsmarktperspectieven heeft. Door het opnemen van deze variabele wordt er voor zorggedragen dat het stijgende aanbod van hoger opgeleiden ook leidt tot een toenemende prognose van de vraag naar hoger opgeleiden. Het feit dat met de toename van het aantal hoger opgeleiden waarschijnlijk ook hun arbeidsmarktpositie zal verslechteren wordt hierdoor echter bij de prognoseresultaten gedeeltelijk genegeerd. Vanuit dit oogpunt zou het dan ook een verbetering zijn indien eerst een prognose van de ex ante vraag zou worden opgesteld, zonder hierbij aanbodfactoren een rol te laten spelen, zodat de confrontatie van vraag en aanbod zo zuiver mogelijk blijft. In aansluiting daarop zou dan kunnen worden aangegeven op welke wijze de arbeidsmarktperspectieven zich voor de verschillende opleidingstypen naar verwachting zullen manifesteren.

De tweede stap ter bepaling van de uitbreidingsvraag per opleidingstype heeft betrekking op de verbijzondering van de uitbreidingsvraag per opleidingsniveau naar de vraag per opleidingstype. In deze tweede stap is een vergelijkbare methodiek gehanteerd. Daarbij zijn echter geen economische verklarende variabelen opgenomen. Het model bevat alleen beroepsklasse- en bedrijfssectorconstanten en een trendterm.

Omdat de modellen voor de prognoses van de uitbreidingsvraag per opleidingstype qua methodiek vergelijkbaar zijn met het model voor beroepsklassen, doen zich hier ook vergelijkbare problemen voor. Ook hier is het moeilijk goed bruikbare verklarende variabelen te vinden en levert de specificatie en de schatting vergelijkbare problemen op met betrekking tot de stabiliteit en betrouwbaarheid van de prognoses. Hoewel er geen modelselectie is toegepast blijken de 
parameterschattingen regelmatig zeer instabiele resultaten op te leveren vanwege de zeer korte tijdreeks die beschikbaar was. Bovendien is bij de specificatie wederom geen rekening gehouden met de informatieve waarde die besloten ligt in het verschil tussen het verklaarde en het feitelijke aantal werkzame personen in het laatste waarnemingsjaar. Verder doet zich bij het opleidingenmodel nog het probleem voor dat, omdat de ex ante en ex post vraag van elkaar kunnen verschillen, de beschikbare data, die betrekking hebben op de ex post vraag, niet zonder meer gebruikt kunnen worden om prognoses te maken van de ex ante vraag. Dit probleem komt aan de orde in Borghans en Heijke (1993), die ook een eerste aanzet geven om de onderlinge verdringingsen substitutie-effecten tussen opleidingen expliciet in de opleidingsprognoses te verwerken.

\section{Conclusies}

Net als bij de uitbreidingsvraag naar beroepsklasse, is er bij het model voor de uitbreidingsvraag per opleidingstype sprake van problemen met de instabiliteit van parameterschattingen en is er in dit model een specificatie gekozen waardoor de informatieve waarde van de laatste waarnemingsperiode niet volledig wordt benut. Omdat het moeilijk is op opleidings- en beroepenniveau geschikte verklarende variabelen te vinden en omdat bij de vraag naar opleidingstypen de onderlinge concurrentie, substitutie en verdringing een grote rol spelen, ligt het voor de hand bij de verdere ontwikkeling van het model vooral hier de aandacht naar te laten uitgaan. Van groot belang bij de verdere ontwikkeling is de robuustheid van het model, omdat grote voorspelfouten leiden tot onbruikbare prognoses met betrekking tot de discrepantie tussen vraag en aanbod.

Omdat de interpretatie van de discrepantie tussen vraag en aanbod als een indicator van arbeidsmarktspanningen tamelijk abstract is, lijkt het belangrijk om naast deze spanningsindicator ook prognoses te maken over de wijze waarop de markt zich aan zal passen aan de situatie. De schoolverlatersenquêtes HBO-monitor en RUBS zijn hiervoor zeer geschikt. De beschrijvingen van de arbeidsmarktpositie van opleidingen zou dan naast een algemene typering van de toekomstige arbeidsmarktpositie, op grond van een vergelijking tussen vraag en aanbod, ook informatie kunnen bevatten over de mate van onderbenutting, het voorkomen van relatief lage lonen etc., waar deze aanleiding toe zou kunnen geven. Door ook prognoses te maken voor de vraag na aanpassing van de markt (de ex post vraag) kunnen dan, ten slotte, ook de werkelijke werkgelegenheidseffecten van deze discrepanties voorspeld worden. Voorspellingen over de uitingsvorm van arbeidsmarktspanningen zullen echter altijd met meer onzekerheid omgeven zijn dan de indicatieve prognoses van de spanning op de arbeidsmarkt zelf.

\subsection{Vervangingsvraag per opleidingstype}

De methodiek die gehanteerd is voor de vervangingsvraag per beroepsklasse kon toentertijd niet gehanteerd worden voor de vervangingsvraag per opleidingstype. De benodigde data van de beroepsbevolking per opleidingstype, geslacht, en leeftijdscategorie, waren op dat moment niet beschikbaar. Verder was het ook niet zinvol om de vervangingsvraagprognoses per beroepsklasse om te zetten naar de vervangingsvraag per opleidingstype, omdat dan de baan-baan-mobiliteit ten onrechte als component van de vervangingsvraag per opleidingstype zou worden meegeteld. 
Ook bij opleidingstypen werden net als bij de vervangingsvraag per beroepsklasse (paragraaf 2.5) in feite prognoses gemaakt van de uitstroom. De mogelijk negatieve uitbreidingsvraag en deze uitstroom werden immers zonder meer gesaldeerd. Als alternatief voor de prognosemethodiek bij de beroepsklassen is bij de opleidingstypen de verwachte vervangingsvraag gebaseerd op het aandeel van werkenden ouder dan 55 jaar in de beroepsbevolking met een bepaalde opleidingsachtergrond. Dit is een vrij eenvoudige aanpak die berust op de veronderstelling dat bij alle opleidingen, doordat de beroepsmobiliteit kan worden genegeerd, de uitstroom van de arbeidsmarkt pas op gang komt op latere leeftijden. Bovendien werd aangenomen dat, net zoals verondersteld werd bij de vervangingsvraag per beroepsklasse, de uitstroom niet afhangt van de uitbreidingsvraag voor het desbetreffende opleidingstype. Overigens is wel, net als bij de vervangingsvraag per beroepsklasse, een correctie gemaakt op basis van werkgelegenheidsprognoses per leeftijdsgroep voor de beroepsbevolking als geheel. Later is ook hier een correctie voor veranderingen in de algehele participatiegraad per leeftijdscategorie aan toegevoegd. Bij deze correcties bevatten echter geen opleidingsspecifieke elementen.

Inmiddels zijn de benodigde data, vergelijkbaar met de data gebruikt bij de vervangingsvraag per beroepsklasse, wel beschikbaar. De vervangingsvraag per opleidingstype wordt nu ook bepaald op basis van de methode van Willems en De Grip $(1990)^{10}$. Dit betekent dat niet de uitstroom maar de vervangingsvraag wordt voorspeld. De impliciete veronderstelling hierbij is dat de vervangingsvraag niet, en dus de uitstroom wel, afhangt van de uitbreidingsvraag. Het is echter de vraag of deze aanname net als bij de beroepsklassen meer plausibel is dan de aanname dat de uitstroom niet beïnvloed wordt door de werkgelegenheidsontwikkeling. De veronderstelling berust namelijk op de aanname dat bij een negatieve uitbreidingsvraag de gevolgen van de krimp terecht komen bij de oudere werknemers en niet bij de nieuwkomers. Bij beroepsklassen is het goed denkbaar dat de reeds werkzame personen bij een krimpende werkgelegenheid uitwijken naar andere beroepsklassen, maar bij opleidingstypen betekent dit automatisch dat de extra uitstroom de arbeidsmarkt verlaat. Dit laatste is een veel verdergaande veronderstelling ${ }^{11}$. Omdat een krimp in de werkgelegenheid per opleidingstype niet vaak voorkomt is de keuze tussen een constante uitstroom of een constante vervangingsvraag praktisch echter minder relevant. Uiteraard blijft wel staan dat voor de interpretatie van de opbouw van de baanopeningen, vervangingsvraag een natuurlijker concept is dan uitstroom.

\section{Conclusies}

Concluderend kan gesteld worden dat bij de vervangingsvraag per opleidingstype vergelijkbare

10. Willems en De Grip (1990) beschikten nog niet over de data opleidingstype $x$ leeftijd/geslacht, zodat de vervangingsvraagprognoses per opleidingstype indirect, op basis van gegevens over beroepsklasse $x$ leeftijd/geslacht en beroepsklasse $x$ opleidingstype moesten worden gemaakt. Thans zijn deze data wel beschikbaar, zodat voor de vervangingsvraag van opleidingstypen dezelfde methode als voor beroepsklassen kan worden gehanteerd.

11. Omdat bij opleidingstypen de ex post vraag niet gelijk is aan de ex ante vraag is deze relatie overigens moeilijker vast te stellen dan bij beroepsklassen. De ex post vraag die wordt waargenomen is immers niet 'exogeen', maar wordt zelf mede bepaald door in- en uitstroom. Voor een adequate analyse zou daarom een verband moeten worden gelegd tussen de ex ante vraag en de uitstroom. 
problemen een rol spelen als bij de vervangingsvraag per beroepsklasse. Als de prognoses niet meer eenvoudigweg afhangen van het aantal personen boven een bepaalde leeftijd, maar worden bepaald op basis van historische uitstroomcijfers, speelt allereerst het meetprobleem weer een rol. Verder zal onderzocht moeten worden wat het verband is tussen de (ex ante) uitbreidingsvraag en de uitstroom. Het is echter niet vanzelfsprekend dat bij opleidingstypen hetzelfde verband wordt gevonden als bij beroepsklassen.

\subsection{Aanbod per opleidingstype}

Omdat het informatiesysteem onderwijs-arbeidsmarkt tot doel heeft de arbeidsmarktperspectieven van studenten aan te geven, kan niet worden volstaan met werkgelegenheidsprognoses. Vanuit een individueel perspectief is het immers ook relevant hoeveel studenten om deze nieuwe banen concurreren. Bij de prognoses die destijds zijn gemaakt is verondersteld dat deze concurrentie zich afspeelt tussen de schoolverlaters met dezelfde studierichting. Bij latere prognoses, zijn hieraan de kortdurig werklozen toegevoegd. Omdat de arbeidsmarkt niet uit een aantal volledig afgebakende segmenten bestaat, zullen schoolverlaters echter ook concurrentie ondervinden van schoolverlaters van andere studierichtingen. In Borghans en Heijke (1993) wordt een aanzet gegeven met deze onderlinge concurrentie in de prognoses rekening te houden ${ }^{12}$.

Voor het opstellen van prognoses van de uitstroom van leerlingen uit het onderwijs is op de eerste plaats gebruik gemaakt van de zogenaamde Skill-prognoses. Dit waren prognoses van het CPB over de leerlingenbezetting in het dagonderwijs en het aantal leerlingen dat een opleiding, met of zonder diploma, beëindigd. Thans worden vergelijkbare prognoses onder de naam 'Referentieraming' gemaakt door het Ministerie van Onderwijs en Wetenschappen. Het aggregatieniveau van de Skillgegevens was echter hoger dan het aggregatieniveau van de opleidingstypen die in het informatiesysteem werden onderscheiden.

In Worsa (Wetenschappelijk Onderwijs Raming Studenten Aantallen) en Rhobos (Raming Hoger Beroeps Onderwijs Studentenaantallen) van de Taakgroep Studentenramingen werden destijds voor respectievelijk het wetenschappelijk en het hoger beroepsonderwijs verder opgesplitste ramingen opgesteld voor het aantal personen dat het onderwijs verlaat. Beide prognoses waren overigens gebaseerd op de Skill-prognose van het CPB. De verbijzonderingen die in Worsa en Rhobos werden gemaakt sloten echter niet geheel aan bij de opleidingenclassificatie van het informatiesysteem. Om die reden moest een aantal opleidingen worden samengenomen of juist worden opgesplitst.

Voor het lager en middelbaar beroepsonderwijs en het algemeen voortgezet onderwijs waren geen equivalenten beschikbaar van studies zoals Rhobos en Worsa. Daarom moest hier direct worden uitgegaan van de Skill-prognoses en werden op basis van de onderwijsmatrix 1985 verbijzonderingen gemaakt naar de in het informatiesysteem onderscheiden opleidingstypen. Vervolgens moesten de ramingen van het aantal gediplomeerden worden omgezet in uitstroom-

12. In Borghans (1992) en Van der Velden en Borghans (1993) wordt de concurrentiepositie van opleidingstypen in beeld gebracht. 
aantallen uit het onderwijs, omdat het ook mogelijk is dat leerlingen doorstromen naar vervolgopleidingen in het dagonderwijs.

Naast de gediplomeerde schoolverlaters onderscheidde Skill ook schoolverlaters die het desbetreffende onderwijstype zonder diploma verlaten. Met behulp van de onderwijsmatrix werd deze groep alsnog toegerekend aan de vooropleiding die zij wel met een diploma hebben afgesloten.

Ook voor het niet-reguliere onderwijs (leerlingwezen, erkende schriftelijke opleidingen, gezondheidszorgopleidingen e.d.) zijn prognoses gemaakt voor de instroom op de arbeidsmarkt. Skill bevatte geen prognoses voor deze opleidingen, zodat deze prognoses gebaseerd moesten worden op additionele statistieken van het CBS, het CORO en rechtstreekse contacten met bepaalde opleidingen. Omdat mensen die deze niet-reguliere opleidingen volgen, reeds beschikbaar waren voor de arbeidsmarkt voordat ze de studie beëindigden werden de geslaagden als een minpost versleuteld over de reguliere vooropleidingen waarmee men in het niet-reguliere onderwijs instroomde. Daarbij wordt impliciet aangenomen dat degenen die een niet-reguliere vervolgopleiding volgen altijd recent zijn uitgestroomd uit het reguliere onderwijs ${ }^{13}$. De aanbodcategorie waarmee gesaldeerd wordt betreft immers alleen schoolverlaters.

De aanbodprognoses zijn gebaseerd op een groot aantal aannames voor specifieke onderdelen van de instroom op de arbeidsmarkt. Dit wordt veroorzaakt doordat de beschikbare prognoses niet het vereiste aggregatieniveau hebben en doordat, met name met betrekking tot het niet-reguliere onderwijs, de beschikbare data onvolledig zijn. Bij de aanpak die destijds werd gevolgd werden de Skill-prognoses rechtstreeks vertaald naar prognoses met betrekking tot de instroom van schoolverlaters per ROA-opleidingstype, met een herindeling op basis van actuele data uit additionele statistieken. Door deze methode resulteren er alleen cijfers per ROA-opleidingstype met betrekking tot de prognosejaren en zijn er geen actuele arbeidsmarktinstroomcijfers beschikbaar. Verder impliceert de combinatie van prognoses en actuele data dat op sommige punten automatisch verondersteld wordt dat bepaalde verhoudingen constant zullen blijven in de tijd. Indien de data dit toe zouden laten zou het wellicht beter zijn als eerst een reeks historische cijfers op het niveau van ROA-opleidingstypen geconstrueerd zou worden. Op basis hiervan zouden dan prognoses gemaakt kunnen worden, waarbij de Referentieraming van het Ministerie van Onderwijs en Wetenschappen als restrictie zou kunnen dienen.

Overigens impliceert het feit dat de methodiek van de aanbodprognoses onmiddelijk prognoses oplevert, zonder eerst historische data te reconstrueren, dat het niet mogelijk is deze prognoses empirisch te evalueren. Om tot geschikte evaluatiecijfers te komen op het aggregatieniveau dat in het informatiesysteem wordt gehanteerd, zouden reconstructies van de data moeten plaatsvinden die vergelijkbaar zijn met de aanpassingen die in de prognoses hebben plaatsgevonden. Hierdoor

13. De omscholing van personen die aan het begin van de prognoseperiode reeds werkzaam waren bij de vervangingsvraagmethodiek die thans wordt gebruikt in principe tot positieve vervangingsvraag bij de opleiding waaronder men voor de omscholing stond geregistreerd, en vanwege het feit dat alleen nettoeffecten worden waargenomen, doorgaans tot een negatieve vervangingsvraag bij de opleidingsrichting waarvan men het diploma heeft behaald. 
zouden deze aanpassingen zelf niet geëvalueerd kunnen worden. Om deze reden is de evaluatie van de aanbodprognoses in hoofdstuk 4 beperkt tot een evaluatie van de Skill-prognoses.

\subsection{De confrontatie van vraag en aanbod}

Om een beeld te kunnen krijgen van het toekomstig arbeidsmarktperspectief van opleidingen moet een confrontatie gemaakt worden van vraag en aanbod. Dit gebeurde toentertijd door middel van de arbeidsmarktindicator AMI. De AMI is het quotiënt van het aanbod van en de vraag naar nieuwkomers. Zoals eerder is opgemerkt, moet een dergelijke verhouding tussen vraag en aanbod niet worden geïnterpreteerd als een indicator van het aantal schoolverlaters dat werkloos zal worden, of het aantal banen dat vacant zal blijven.

De werkelijke betekenis van de confrontatie tussen vraag en aanbod is dat deze aangeeft welke spanningen zich op de arbeidsmarkt naar verwachting voor zullen doen. De arbeidsmarkt zal zich waarschijnlijk voor een groot deel aanpassen aan deze spanningen, maar dit zal wel de arbeidsmarktpositie van de betreffende opleidingen veranderen. Als er een overschot aan schoolverlaters is, betekent dit dus niet automatisch dat zij werkloos zullen worden. Het impliceert dat zij naar verwachting minder aantrekkelijke banen zullen krijgen, een slechtere beloning zullen ontvangen en een grotere kans op werkloosheid hebben.

Bij de bepaling van de verhouding tussen vraag en aanbod spelen twee factoren een belangrijke rol. Ten eerste moet worden bepaald welke groepen meegerekend worden bij de vraag en het aanbod. Het uitgangspunt van de arbeidsmarktindicator is, omdat het primaire doel van de prognoses de studie- en beroepskeuzebegeleiding is, dat hij een beeld moet geven van de specifieke arbeidsmarktpositie van schoolverlaters. Om een voor de schoolverlaters relevante indicatie van de arbeidsmarktpositie te geven moet echter de verhouding worden weergegeven tussen het aantal banen dat in principe voor hen beschikbaar is, en de totale omvang van de groep die om deze banen moet concurreren.

Bij de toentertijd berekende AMI is bij het aanbod alleen uitgegaan van de schoolverlaters zelf. Later is deze groep uitgebreid met de kortdurig werklozen aan het begin van de prognoseperiode, waarvan verondersteld wordt dat deze personen serieuze concurrentie vormen voor de schoolverlaters. Bij de vraag wordt uiteraard alleen het aantal baanopeningen in de analyse betrokken. Aangenomen wordt derhalve dat de bestaande banen die niet vrijkomen door het vertrek van de huidige werknemers, niet beschikbaar zijn voor de schoolverlaters. Als men zou veronderstellen dat in principe altijd weer om alle banen concurrentie plaats kan vinden, dan zou de totale werkgelegenheid zowel als vraag- als aanbodcategorie moeten worden meegenomen. Bij de vraag zou dan geen rekening meer gehouden hoeven worden met de vervangingsvraag. In plaats daarvan zou bij het aanbod de uitstroom in mindering gebracht moeten worden.

Een tweede belangrijke factor bij de bepaling van de toekomstige arbeidsmarktsituatie betreft de stabiliteit van de indicator. Omdat zowel in de teller als in de noemer prognoses van stromen op 
de arbeidsmarkt opgenomen zijn, zal de arbeidsmarktindicator een zekere instabiliteit vertonen ${ }^{14}$. Met name bij een lage voorspelling van de vraag neemt deze indicator extreem hoge waarden aan. Daarbij moet bedacht worden dat het hier gaat om het quotiënt van twee onzekere factoren. Om de prognoses voldoende trefzeker te maken moet de indicator daarom enig conservatisme bevatten. Dit conservatisme kan op twee wijzen worden gerealiseerd. Ten eerste kunnen de onderdelen conservatief voorspeld worden met het oog op deze confrontatie en ten tweede kan de definitie van de arbeidsmarktindicator zelf een conservatief element bevatten.

Omdat een conservatieve prognose van de vraag-aanbod-verhoudingen vooral betekent dat de afwijking tussen vraag en aanbod niet exceptioneel groot moeten worden ingeschat, is het echter moeilijk deze voorzichtigheid bij de afzonderlijke onderdelen te implementeren. Om die reden wordt sinds 1990 een definitie van de ITA (de huidige benaming van de arbeidsmarktindicator) gehanteerd waarin als stabiliserend element zowel in de teller als in de noemer de totale werkgelegenheid van het betreffende opleidingstype is opgenomen. Op het eerste gezicht lijkt hiermee de vraag-aanbodconfrontatie weer op het niveau van de gehele arbeidsmarkt plaats te vinden. Alleen de behandeling van de uitstroom wijkt af van de hierboven beschreven confrontatie van de totale vraag naar werkenden met het totale aanbod. De aanpassing van de definitie van de ITA kan echter beter geïnterpreteerd worden als een voorzichtigheidsprincipe. Indien de arbeidsmarkt in evenwicht is zal de vraag naar nieuwkomers gelijk zijn aan het aanbod van nieuwkomers. Bij benadering zal deze vraag of dit aanbod gelijk zijn aan een fractie van het totale aantal werkzame personen met de betreffende opleiding. Stel bijvoorbeeld dat de evenwichtige vraag $\left(V_{i}^{e v}\right)$ en het evenwichtig aanbod $\left(A_{i}^{e v}\right)$ beide gelijk zijn aan 7/40-ste deel van het aantal werkzame personen ( 7 is het aantal prognose-jaren en 40 de lengte van een arbeidsmarktloopbaan). Dit evenwichtige vraag-aanbodcijfer kan geïnterpreteerd worden als een uiterst voorzichtige prognose van zowel de vraag als het aanbod. Om de stabiliteit van de arbeidsmarktindicator te vergroten worden teller en noemer van de indicator samengesteld uit een gewogen gemiddelde van zowel de aanbodprognose en de conservatieve schatting en de vraagprognose en de conservatieve schatting. De definitie luidt dan:

$$
I T A_{i}=\frac{g_{A} \hat{A}_{i}+\left(1-g_{A}\right) A_{i}^{e v}}{g_{V} \hat{V}_{i}+\left(1-g_{V}\right) V_{i}^{e v}}
$$

waarin $g_{A}$ en $g_{V}$ de gewichten zijn die aan beide onderdelen, vraag en aanbod, worden toegekend.

Deze aanpak heeft een stabiliserende werking op de arbeidsmarktindicator. De stabiliserende werking is het sterkst voor die opleidingen waar zowel vraag als aanbod sterk afwijken van de evenwichtige vraag. Gezien de onzekerheden die in de prognoses zitten is het hanteren van een dergelijke conservatieve definitie van de ITA waarschijnlijk een belangrijke verbetering. De vraag is echter alleen in welke mate deze voorzichtigheid geïntroduceerd moet worden. Impliciet in de definitie zoals die thans gehanteerd wordt zit een verhouding van $1: \frac{40}{7}=1: 5,7$, omdat het aantal werkzame personen in zijn geheel bij de vraag en het aanbod wordt gevoegd. De definitie legt dus veel gewicht op de evenwichtige vraag/aanbod, en relatief weinig gewicht op de feitelijke

14. Bij de prognoses van 1989 kon deze verhouding zelfs nog negatief zijn, omdat de totale vraag naar nieuwkomers negatief kon zijn. Door echter op een consistente wijze de uitstroom of vervangingsvraag te definieren is dit bij latere prognoses niet meer mogelijk. 
prognoses. Voor een betere onderbouwing van dit gewicht zou een nadere analyse van de voorspelfouten en hun invloed op de arbeidsmarktindicator gemaakt moeten worden.

\subsection{Kwalitatieve typeringen}

De in de vorige paragrafen besproken onderdelen van het prognosemodel betreffen allemaal voorspelmethodes die puntschattingen van bepaalde onderdelen van de toekomstige arbeidsmarktsituatie opleveren. Zulke puntprognoses suggereren een hogere graad van precisie dan kan worden waargemaakt. Bovendien zijn dergelijke schattingen voor gebruikers vaak moeilijk eenduidig interpreteerbaar. Daarom zijn in het informatiesysteem alle kwantitatieve prognoseresultaten omgezet in een kwalitatieve typering, meestal varierend van 'erg laag', 'laag', 'gemiddeld', 'hoog', tot 'erg hoog'. Op deze wijze worden alle prognoseresultaten op deze vijfpunts-schaal gepositioneerd. Toentertijd gebeurde dit nog op ad hoc basis. Wieling, De Grip en Willems (1990) introduceerden echter een systematiek waarbij afhankelijk van de spreiding van de prognoseresultaten de grenzen tussen de verschillende kwalitatieve typeringen werden vastgesteld. Hierdoor wordt een evenwichtige spreiding van de prognoses over de typeringen bewerkstelligd.

De vertaalslag naar de kwalitatieve typeringen werkt zeer verduidelijkend, zodat dit gebruik zelf niet ter discussie hoeft te worden gesteld. De vraag die dan echter overblijft, is op welke wijze de intervalgrenzen bepaald moeten worden. Hierbij spelen een aantal overwegingen een rol. Het is aan de ene kant van belang de afbakening van de kwalitatieve typeringen zodanig te kiezen dat de kans op een juiste typering voldoende groot is. Aan de andere kant moet de kwalitatieve typering informatief blijven. Men moet de intervallen niet zo groot kiezen dat de typering geen praktische waarde meer heeft. Gegeven de omvang van een interval is het in principe optimaal om een betrouwbaarheidsinterval te selecteren dat symmetrisch rondom de puntschatting ligt. Als ervan wordt uitgegaan dat de kans op onderschatting even groot is als de kans op overschatting dan geeft een symmetrisch interval bij gegeven intervallengte de maximale betrouwbaarheid. Het kiezen van symmetrische intervallen heeft echter als gevolg dat iedere prognose een eigen interval krijgt toegewezen. Het is dan niet meer mogelijk om deze intervallen aan te duiden met een algemene typering als 'hoog' of 'gemiddeld'.

Voor een duidelijke kwalitatieve typering moet derhalve gekozen worden voor vaste intervalgrenzen. De consequentie hiervan is dat bepaalde prognoses in de buurt van een intervalgrens komen te liggen. Figuur 2.3 laat zien dat dit leidt tot een vermindering van de betrouwbaarheid van de gegeven typeringen. De figuur geeft een kansverdeling voor de realisatie van een bepaalde grootheid rondom de prognose. Het gearceerde gebied bij (a) geeft de kans weer dat bij een symmetrisch interval rondom de puntschatting de realisatie binnen deze intervalgrenzen valt. Deze kans zal aanzienlijk verminderen als de prognose dichtbij de grens van het interval komt te liggen (b). In feite is dit de prijs, in termen van betrouwbaarheid, van het gebruik van vaste intervalgrenzen. Echter de kwalitatieve typering kent ook twee extreme intervallen 'erg laag' en 'erg hoog'. Hierbij is het gehanteerde interval slechts aan éen kant begrensd. Dit zal doorgaans, zoals curve (c) laat zien, de kans op een juiste typering sterk vergroten. Als er veel prognoses in deze extreme categorieën terecht komen, gaat echter het onderscheidend vermogen van de kwalitatieve 
typering verloren. Er moet daarom voor worden zorggedragen dat in deze intervallen alleen prognoses terecht komen die dermate extreem zijn dat hun onderlinge omvang niet meer relevant is voor de ondersteuning van de studie- en beroepskeuze.

Figuur 2.3. De kansen op een juiste typering bij (a) een symmetrisch interval, (b) een vast interval en (c) een vast interval dat aan een zijde onbegrensd is

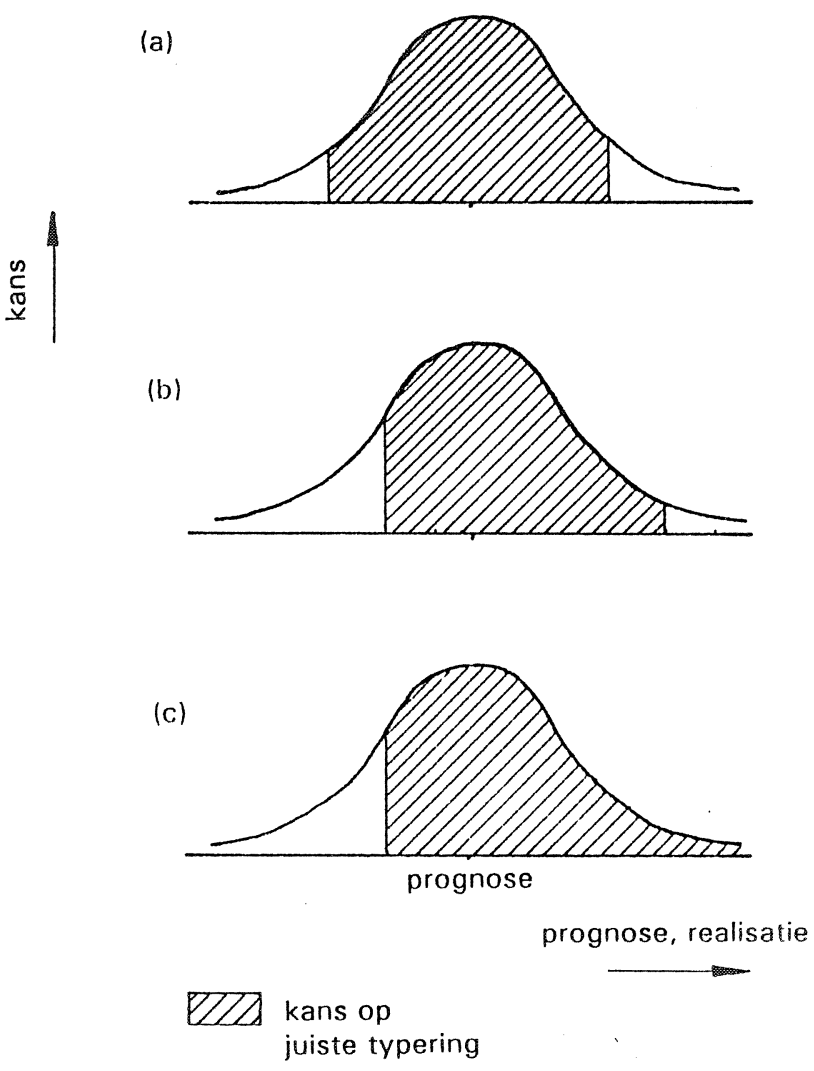

Een tweede belangrijk punt met betrekking tot de bepaling van de grenzen van de intervallen betreft de breedte van de intervallen. Hoewel een typering niet direct geïnterpreteerd moet worden als een betrouwbaarheidsinterval dient de grootte toch zodanig te zijn dat de kans op een juiste typering voldoende groot is. De feitelijke verdeling van de voorspelfout legt dus in ieder geval een ondergrens op aan de intervalgrootte. Bij een aantal van de bij het opstellen van de hier geëvalueerde prognoses gekozen indelingen is de intervalbreedte van de typering 'gemiddeld' echter zeer klein, terwijl de typeringen 'laag' en 'hoog' een grotere intervalbreedte hebben. Deze aanpak is ook overgenomen door Wieling, De Grip en Willems (1990) op basis van de constatering dat een groot aantal prognoses rondom het gemiddelde geconcentreerd ligt. Door het relatief smalle interval voor 'gemiddeld' wordt bewerkstelligd dat er een evenwichtige verdeling over de typeringen tot stand komt. Een gevolg hiervan kan echter zijn dat de betrouwbaarheid van dit middeninterval aanzienlijk lager is dan de betrouwbaarheid van de overige intervallen. Er is immers geen a priori argument waarom typeringen rondom het gemiddelde kleinere voorspelfouten zullen bevatten dan de overige typeringen. 
Figuur 2.4. Verband tussen kwalitatieve typeringen van uitbreidingsvraag, vervangingsvraag en baanopeningen per beroepsklasse

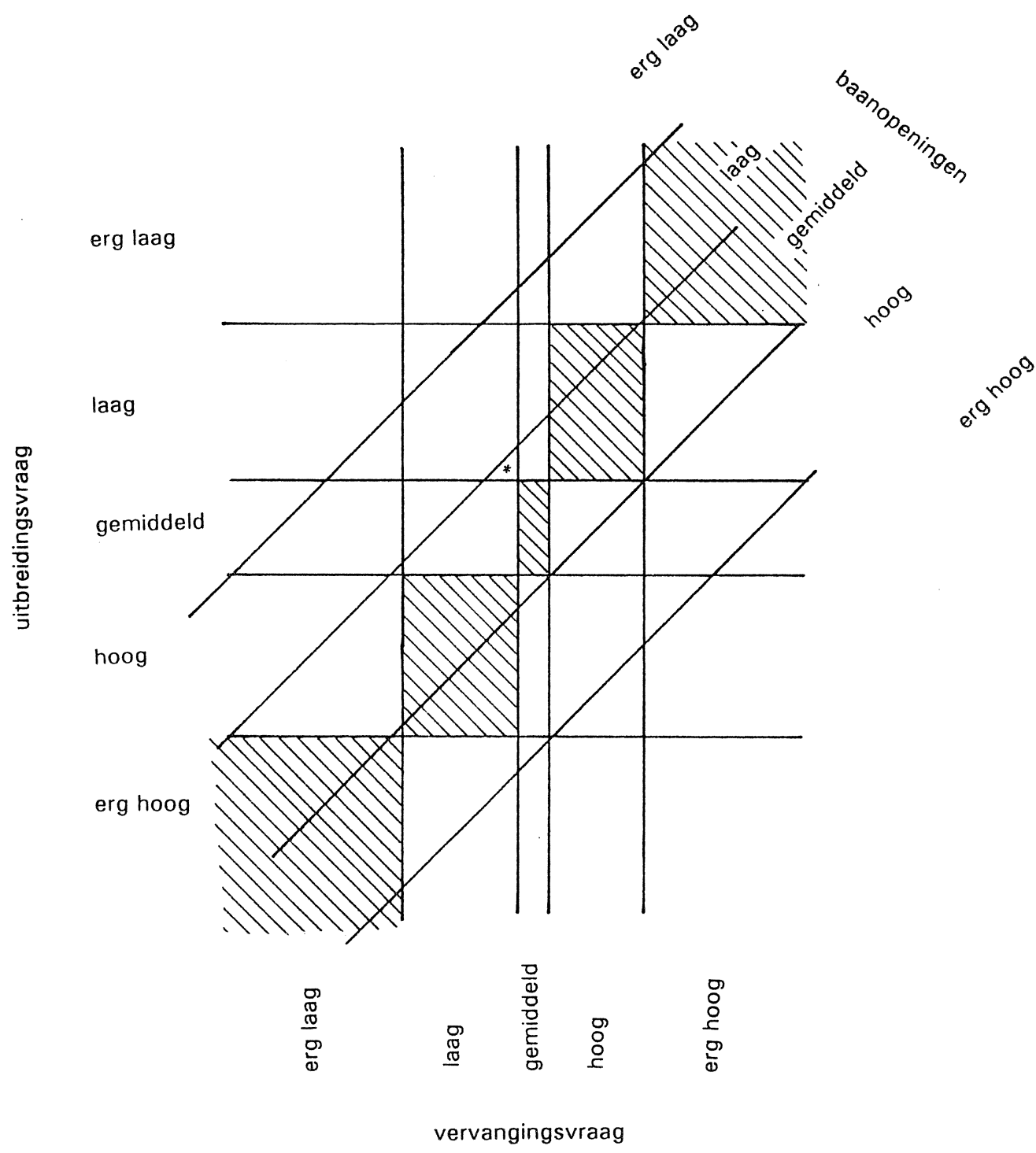

Een derde overweging bij het vaststellen van de grenzen van de typeringsintervallen heeft betrekking op de onderlinge afstemming tussen de diverse onderdelen van het informatiesysteem. De baanopeningen per beroepsklasse zijn de optelsom van de uitbreidingsvraag en de vervangingsvraag. Figuur 2.4 geeft de intervalgrenzen van zowel de uitbreidings- en vervangingsvraag als het totaal aantal baanopeningen aan, en toont ook hun onderlinge afhankelijkheid. Als vervangingsvraag en uitbreidingsvraag gegeven zijn, dan zijn daarmee de baanopeningen vastgelegd op de diagonalen van de figuur. Vergeleken met de intervalbreedte van de typering 'gemiddeld' bij de uitbreidingsvraag en zeker vergeleken met de breedte van de vervangingsvraag bij de typering 'gemiddeld', is het interval van de typering 'gemiddeld' bij de baanopeningen zeer breed. Dit heeft als gevolg dat bij een beroepsklasse waar sprake is van zowel een lage vervangingsvraag als een lage uitbreidingsvraag toch het aantal baanopeningen als 'gemiddeld' kan worden getypeerd (zie * in de figuur). Ook zou verwacht mogen worden dat een hoge uitbreidingsvraag een lage vervangingsvraag 
compenseert en een erg lage uitbreidingsvraag een erg hoge vervangingsvraag neutraliseert. In de figuur zijn deze gebieden gearceerd. Het blijkt echter dat bij een erg hoge uitbreidingsvraag en een erg lage vervangingsvraag veelal sprake zal zijn van een hoog aantal baanopeningen, terwijl er bij de omgekeerde situatie meestal sprake is van een laag aantal baanopeningen.

Dit soort discrepanties zouden voorkomen kunnen worden door voor de afzonderlijke onderdelen gelijke intervalbreedtes te kiezen en de intervalbreedtes over de hele schaal constant te houden. Indien de prognoses van een van beide componenten van het totaal aantal baanopeningen een onzekerheid vertonen, die een grotere intervalbreedte vereist, is het vanuit het oogpunt van deze systematiek wellicht het meest zinvol om te typeren op basis van een dubbele intervalaanduiding. Door de prognoses te typeren met 'laag tot erg laag', 'gemiddeld tot laag', 'gemiddeld tot hoog' en 'hoog tot erg hoog' blijft de onderlinge consistentie behouden, terwijl de intervalbreedte wordt verdubbeld. Bovendien kunnen deze overlappende typeringen ook bewerkstelligen dat de prognoses redelijk in het centrum van hun interval komen te liggen.

\subsection{Risico-indicatoren}

Naast de prognoses met betrekking tot de verwachte arbeidsmarktperspectieven van opleidingstypen en de baanopeningen per beroepsklasse, bevat het informatiesysteem voor de verschillende opleidingstypen en beroepsklassen, afgezien van de actuele data, ook risicoindicatoren. De actuele data beogen de huidige arbeidsmarktsituatie in beeld te brengen, onder andere om de voorspellingen van de toekomstige arbeidsmarktsituatie in het licht van de huidige arbeidsmarktsituatie te kunnen bekijken. De risico-indicatoren vullen deze informatie aan met meer structurele gegevens over de arbeidsmarktpositie van opleidingstypen en beroepsklassen. Zij geven informatie over het risico dat de arbeidsmarktsituatie, zoals die nu naar voren komt uit de actuele data en de prognoses voor de nabije toekomst, snel zouden kunnen wijzigen. Hierdoor vormen zij een indicatie voor de mate waarin men, eenmaal op de arbeidsmarkt, nog verdere veranderingen van het perspectief kan verwachten. Bovendien geven de risico-indicatoren een indicatie van de kans dat er zelfs voordat de prognosestermijn is verstreken reeds onverwachte invloeden de perspectieven zouden kunnen veranderen. De indicatoren geven dus zowel een langetermijnperspectief, alsook de betrouwbaarheid van de prognoses aan.

\section{Conjunctuurindicator}

De conjunctuurindicator heeft betrekking op de conjunctuurgevoeligheid van de werkgelegenheid in de verschillende beroepsklassen. Eerst is per bedrijfssector vastgesteld in hoeverre de werkgelegenheid onderhevig is aan conjuncturele schommelingen. Voor iedere beroepsklasse is de conjunctuurindicator vervolgens berekend als een gewogen gemiddelde van de sectorale fluctuaties van de werkgelegenheidsontwikkeling. Door de conjunctuurindicator van beroepsklassen te relateren aan de schommelingen van de werkgelegenheid in bedrijfssectoren, kan de indicator op een voldoende lange tijdreeks gebaseerd worden. Het is immers niet mogelijk om op basis van vier AKT-jaargangen de conjunctuurgevoeligheid van beroepsklassen direct te meten. Een nadeel van deze aanpak is dat impliciet de veronderstelling gemaakt wordt dat binnen een bedrijfssector alle 
beroepen dezelfde mate van conjunctuurgevoeligheid hebben ${ }^{15}$. Bij de industriële bedrijfssectoren is echter waarschijnlijk de conjunctuurgevoeligheid van de produktieberoepen groter dan die van het stafpersoneel. Doordat de typische overheadberoepen doorgaans in meer bedrijfssectoren werkzaam zijn dan de meer sectorspecifieke produktieberoepen, zal in de praktijk de conjunctuurgevoeligheid van de eerstgenoemde beroepen toch lager uitvallen dan die van een beroepsklasse die met name werkzaam is binnen een bepaalde industriële bedrijfssector.

\section{Uitwijkmogelijkheden}

De tweede risicoindicator die zowel bij de opleidingstypen als bij de beroepsklassen gehanteerd wordt is de indicator van de uitwijkmogelijkheden op de arbeidsmarkt. Deze indicator geeft aan in welke mate de werkgelegenheid gespreid is. Bij beroepsklassen heeft de indicator betrekking op de spreiding over de bedrijfssectoren. Bij de opleidingstypen gaat het zowel om de spreiding over bedrijfssectoren als over beroepsklassen. De gedachte achter deze indicator is dat als bijvoorbeeld personen met een bepaalde opleiding werkzaam kunnen zijn in meerdere beroepsklassen, zij niet volledig afhankelijk zijn van de werkgelegenheidsontwikkeling in één specifiek beroep, waardoor zij als de perspectieven bij één beroep plotseling verslechteren, kunnen uitwijken naar andere beroepsklassen.

Een tekortkoming van deze maatstaf is de veronderstelling dat de uitwijkmogelijkheden overeenkomen met de beroepsklassen of bedrijfssectoren waarin de werkenden in het desbetreffende beroep of met de desbetreffende opleidingsachtergrond momenteel werkzaam zijn. Bij opleidingen waarbij nog nooit de noodzaak heeft bestaan om uit te wijken naar andere beroepsklassen, kan deze feitelijke verdeling van personen over de beroepsklassen derhalve de uitwijkmogelijkheden onderschatten. Om die reden is inmiddels een aangepaste uitwijkindicator tot stand gekomen waarin een correctie plaatsvindt voor het noodzakelijkergewijs moeten uitwijken naar functies waarin sprake is van onderbenutting.

15. De noodzaak een dergelijke veronderstelling te maken is ook de reden geweest deze conjunctuurindicator niet per opleidingstype te bepalen. 


\section{EEN METHODE VOOR DE EMPIRISCHE EVALUATIE}

\subsection{Inleiding}

In het vorige hoofdstuk is de opzet van het informatiesysteem aan de orde gekomen. De prognoses zoals die destijds gemaakt zijn voor de onderdelen van dit systeem zullen in het volgende hoofdstuk, voorzover mogelijk, worden onderworpen aan een empirische evaluatie. Om deze empirische evaluatie een systematisch karakter te geven wordt in dit hoofdstuk eerst een evaluatiemethode beschreven. Allereerst wordt in paragraaf 3.2 ingegaan op de problemen die zich voordoen bij de empirische evaluatie. Vervolgens wordt op basis van de doelstelling van het informatiesysteem een evaluatiecriterium geïntroduceerd (paragraaf 3.3). Dit criterium geeft met name een waardering van het verlies dat ontstaat door de voorspelfouten. Om meer zicht te krijgen op de oorzaken van de voorspelfouten worden in paragraaf 3.4 enkele toetsen besproken. Ten slotte komt in paragraaf 3.5 de evaluatie van de kwalitatieve typeringen aan de orde.

\subsection{Problemen bij de empirische evaluatie}

Een empirische evaluatie berust primair op het vergelijken van de prognoses met de feitelijke realisaties. Er doen zich twee soorten problemen voor bij het evalueren van de prognoses. Het eerste probleem heeft betrekking op de prognoses zelf. Uiteraard zijn de gemaakte prognoses altijd beschikbaar voor evaluatie, maar soms hebben zij betrekking op theoretische concepten die zelf niet waarneembaar zijn. Een voorbeeld hiervan is de al eerder genoemde spanning tussen vraag en aanbod. Dit betreft een indicator over de toekomstige arbeidsmarktsituatie die in zijn algemeenheid niet meetbaar is. De indicator krijgt pas betekenis in relatie met de mogelijke consequenties van de verwachte arbeidsmarktontwikkelingen, zoals lagere lonen, hogere werkloosheid, onderbenutting, etc. Om de voorspellingen over de spanning tussen vraag en aanbod te kunnen evalueren, moet dus duidelijk zijn welk verband er bestaat tussen de spanningsindicator en de grootheden die wel direct meetbaar zijn.

Een tweede mogelijk probleem bij de confrontatie tussen prognose en realisatie is het ontbreken van data met betrekking tot de realisaties. Dit probleem doet zich veelvuldig voor en heeft een drietal oorzaken. Ten eerste zijn er tussen 1989, het jaar waarin de prognoses werden gemaakt en 1992, het laatste jaar waarop de prognoses betrekking hadden, een aantal classificaties gewijzigd. Ten tweede ontbreken voor een aantal grootheden thans (voor 1992) de cijfers die destijds voor de periode tot 1988 wel beschikbaar waren. Ten derde komt het voor dat er prognoses gemaakt zijn voor grootheden waarover ook destijds geen cijfers bekend waren, zoals bijvoorbeeld de arbeidsmarktintrede van schoolverlaters of de vervangingsvraag naar beroep en opleiding.

De twee dataproblemen die consequenties voor vrijwel alle onderdelen van de evaluatie hebben, zijn de wijzigingen die zijn aangebracht in gehanteerde classificaties en de overgang van de AKT naar de EBB. Zoals in paragraaf 2.3 reeds werd aangegeven, hebben er sinds in 1989 de eerste prognoses werden opgesteld een aantal ingrijpende veranderingen plaatsgevonden in de classificaties die gehanteerd worden binnen het informatiesysteem. De huidige dataverzameling 
vindt plaats op basis van de classificaties die nu worden gehanteerd. Omdat het CBS niet toestaat dat cellen van de datamatrices worden gebruikt met jaarcijfers kleiner dan 2.500 personen is het niet efficiënt om de data te verzamelen op een lager aggregatieniveau dan nodig is voor de analyse. Voor een groot deel van de benodigde data bleek het echter mogelijk de betreffende cijfers in de destijds gehanteerde classificaties te krijgen. Voor het waarborgen van de continuïteit van de evaluaties is een dergelijke flexibiliteit bij de te hanteren classificaties van groot belang. Bij een overstap naar een nieuwe classificatie is het vanuit het oogpunt van evalueerbaarheid van de prognoses van belang dat niet alleen enquêtebestanden uit het verleden omgezet kunnen worden naar de nieuwe classificatie, maar ook dat toekomstige enquêtes nog enige tijd herleidbaar blijven tot de oude classificaties. Een dergelijk probleem kan zich bijvoorbeeld ook voordoen bij de nieuwe beroepenclassificatie die binnenkort door het CBS zal worden geïmplementeerd.

Een tweede algemeen terugkerend probleem met betrekking tot de data bij de empirische evaluatie betreft de overgang van AKT naar EBB. Zoals in paragraaf 2.3 werd beschreven heeft deze overgang er onder andere toegeleid dat veel meer personen met korte werkverbanden tot de werkzame bevolking worden gerekend. Sinds enige tijd wordt dan ook een expliciete ondergrens voor het aantal gewerkte uren gehanteerd om zo de zeer kleine banen buiten de analyse te houden. Omdat bij de prognoses uit 1989 in principe voorspellingen werden gemaakt met betrekking tot alle werkzame personen is besloten ook bij de evaluatie dit criterium aan te houden. Een gevolg hiervan was echter dat de werkzame beroepsbevolking door de ruimere gewijzigde definitie, aanzienlijk groter uitviel. De meeste prognoses vertonen daardoor een tamelijk grote onderschatting. In de evaluatie is dit probleem ondervangen door naar relatieve voorspelfouten te kijken. Dat wil zeggen dat de prognoses gecorrigeerd zijn voor de voorspelfout met betrekking tot het algehele niveau van de werkgelegenheid.

Een bijkomend probleem was dat beroepen beneden de 12-uren-grens sinds 1991 bij de EBB niet meer worden gecodeerd. Om toch zo goed mogelijke cijfers op basis van de 1-uren-grens te verkrijgen zijn de realisatie-cijfers geconstrueerd door de EBB-gegevens uit 1992, die gebaseerd zijn op de 12-uren-grens, te vermenigvuldigen met de verhouding tussen alle banen en de banen boven de 12-uren-grens in 1990. Om de reconstructie zo nauwkeurig mogelijk te maken, is deze herberekening niet gebaseerd op de bedrijfstak-, beroepsklasse-, of opleidingstypetotalen, maar vond hij plaats op basis van de afzonderlijke cellen van de onderliggende matrix bedrijfssector $x$ beroepsklasse, of beroepsklasse $x$ opleidingstype.

Naast deze twee data-problemen die voortdurend terugkeren in de evaluatie, zijn er per onderdeel nog andere aspecten die een directe evaluatie bemoeilijken. Bij de vervangingsvraag betreft dit het probleem dat, op basis van de EBB-data, de stromen op de arbeidsmarkt niet direct meetbaar zijn. De data die gebruikt worden bij de evaluatie zijn daardoor net als de prognoses zelf ook afhankelijk van een deel van het gehanteerde model. Voor dit onderdeel van het model is een empirische evaluatie dus niet mogelijk.

Bij de aanbodvoorspellingen doet zich het probleem voor dat de data met betrekking tot schoolverlaters niet beschikbaar zijn op basis van de door het ROA gehanteerde classificatie. Bij het 
maken van de aanbodprognoses worden voorspellingen op basis van andere classificaties omgezet naar de bij het informatiesysteem gehanteerde classificaties. Hierdoor ontbreken dus data met betrekking tot de realisaties. Bovendien vindt de omzetting plaats op grond van een aantal aannames ten aanzien van de instroom vanuit het niet-reguliere onderwijs. Vanwege de complexiteit van de omzetting - mede door het verwerken van verschillende informatiebronnen over het nietregulier onderwijs - en vanwege het bovengenoemde conceptuele probleem, heeft een dergelijke reconstructie niet plaatsgevonden. Daarom worden in dit rapport alleen de prognose van de aantallen gediplomeerden uit Skill, de belangrijkste bron van de ROA-prognoses worden geëvalueerd. Het is echter van belang om, zowel voor de ontwikkeling van nieuwe prognosemodellen als voor de evaluaties in de toekomst, te komen tot een bestand van schoolverlatersdata op basis van de in het informatiesysteem gehanteerde classificaties.

\subsection{Een evaluatiecriterium}

Het is vaak niet zo zinvol iedere prognose afzonderlijk in beschouwing te nemen, omdat veel voorspelfouten op zich een incidenteel karakter hebben. Het is moeilijk hieruit lessen te trekken. Daarvoor kan beter gekeken worden naar de systematiek in de prognosefouten. Doordat in het ROA-informatiesysteem prognoses zijn gemaakt voor 79 beroepsklassen en 53 opleidingstypen is het echter goed mogelijk, en gezien de hoeveelheid informatie ook wenselijk, afzonderlijke prognosefouten te aggregeren. Deze aggregatie maakt het mogelijk uitspraken te doen over de kansverdeling van de voorspelfouten, in plaats van een afzonderlijke beschouwing van iedere voorspelling te maken.

De vraag die zich hierbij voordoet is echter op welke wijze deze aggregatie van voorspelfouten plaats dient te vinden. Er dient een criterium bepaald te worden dat gewichten toekent aan de afzonderlijke voorspelfouten, zodat deze worden teruggebracht tot één kencijfer. In deze paragraaf komt de keuze van dit evaluatiecriterium aan de orde en wordt ingegaan op de wijze waarop in deze evaluatie dit kencijfer beoordeeld zal worden. Naast een geschikte wijze van samennemen van de afzonderlijke voorspelfouten dient immers ook een oordeel over de kwaliteit van de prognose geveld te worden.

Uitgangspunt bij de beoordeling van de prognoses van het informatiesysteem onderwijsarbeidsmarkt is, zoals gezegd, de doelstelling dat de prognoses geschikt moeten zijn voor de studieen beroepskeuze. De meeste voorspellingen zijn geformuleerd in termen van werkzame personen. Voor een individuele student is echter niet het totale aantal werkzame personen in een beroep of een opleiding, of de absolute afwijking daarvan interessant, maar gaat het vooral om de relatieve afwijking: $\left(x_{i}-\hat{x}_{i}\right) / x_{i}$, waarin $x_{i}$ staat voor de realisatie van een voorspelde grootheid voor beroep of opleiding $\mathrm{i}$, en $\hat{x}_{i}$ de prognose voor dezelfde grootheid aanduidt. Onder de veronderstelling dat deze relatieve maatstaf normaal verdeeld is, is het zinvol om het kwadraat hiervan als verlies van de afzonderlijke prognose te beschouwen (Granger en Newbold, 1986, blz. 277).

(1) $V_{i}\left(\hat{x}_{i}\right)=\left(\frac{x_{i}-\hat{x}_{i}}{x_{i}}\right)^{2}$ 
Het verlies geeft aan hoe groot de 'schade' van een bepaalde voorspelfout is, zodat het mogelijk wordt het gemiddelde verlies te berekenen en zo de voorspelfouten te aggregeren ${ }^{16}$.

Bij het aggregeren van dit criterium moet er rekening mee worden gehouden dat er veel meer leerlingen in een groot beroep of een grote opleidingscategorie terecht komen dan in een kleine. Door te wegen naar de omvang van het beroep of de opleidingscategorie wordt het gemiddeld verlies bepaald. Dit is het evaluatiecriterium op geaggregeerd niveau:

(2) $G V(\hat{x})=\sum_{i} \frac{x_{i}}{x^{\operatorname{tot}}} V_{i}\left(\hat{x}_{i}\right)=\sum_{i} \frac{x_{i}}{x^{\operatorname{tot}}}\left(\frac{x_{i}-\hat{x}_{i}}{x_{i}}\right)^{2}=\sum_{i} \frac{1}{x^{\text {tot }}} \frac{\left(x_{i}-\hat{x}_{i}\right)^{2}}{x_{i}}$

Hierin is $x^{\text {tot }}=\sum x_{i}$ de totale gerealiseerde omvang van de werkzame personen. Het individuele verliescriterium ${ }^{i} V_{i}$ geeft dus bij benadering het verlies dat relevant is voor de keuze van een individuele leerling, die eventueel het betreffende beroep of de betreffende opleiding zal kiezen, terwijl het gemiddeld verlies ( $G V$ het verlies van een gemiddelde leerling aangeeft. De hierboven beschreven evaluatiecriteria zijn van toepassing op de evaluatie van aantallen werkzame personen. Bij de vervangingsvraag en de baanopeningen wordt slechts een deelgroep hiervan voorspeld. Bij de verliesfunctie blijft dan echter toch in de noemer het totale aantal werkzame personen staan, om zo de voorspelfout te blijven relateren aan de omvang van het beroepsklasse of het opleidingstype. Ook ter bepaling van het gemiddeld verlies worden deze totale aantallen als gewicht gebruikt.

De verliesfunctie in (2) is een veel gebruikt criterium en is in deze context onder andere ook gehanteerd door Bosworth, Evans en Lindley (1974), Evans en Lindley (1973), Borghans en Heijke (1993) en Van Eijs en Borghans (1993) voor de evaluatie van manpower-forecasting methoden. Het criterium geeft een schatting van de spreiding van de voorspellingen rond de realisatie en daarmee een antwoord op de tweede eis die Granger en Newbold (1986) stellen aan de objectieve evaluatie. Op grond van dit cijfer is het echter niet mogelijk een uitspraak te doen over de kwaliteit van de prognoses. Er is immers geen informatie beschikbaar over wat een redelijke waarde voor het gemiddeld verlies zou zijn. Om te voorzien in een dergelijke beoordelingsmaatstaf kan de destijds gehanteerde prognose vergeleken worden met de voorspelkwaliteit van andere beschikbare prognoses, conform de eerste eis uit de lijst van Granger en Newbold. Door de verhouding te nemen tussen de voorspelkwaliteit van de prognose en de voorspelkwaliteit van een referentievoorspelling, ontstaat een score die kleiner is dan 1 als de prognose beter is dan de referentieprognose en groter dan 1 als de prognose slechter is:

(3) $S\left(\hat{x}, x^{r e f}\right)=\frac{G V(\hat{x})}{G V\left(x^{r e f}\right)}$

Om invulling te geven aan de score-definitie, moet een bepaalde prognose als referentie-prognose worden bestempeld. Uitgangspunt hiervoor is in dit rapport dat de prognoses vergeleken zullen

16. Als van een leerling nauwkeurig bekend is bij welk niveau van het verwachte arbeidsmarktperspectief hij de studiekeuze zal aanpassen, zou eigenlijk een verliesfunctie met een bepaalde asymmetrische vorm gekozen moeten worden. Omdat deze informatie uiteraard niet bekend is, en omdat een evaluatie zich niet richt op een bepaalde leerling maar op de bruikbaarheid van de informatie voor de gemiddelde leerling voldoet het kwadratisch verliescriterium ook aan de gestelde eisen (Zie Borghans, 1993, hoofdstuk 7). 
worden met de situatie waarin leerlingen zouden verkeren indien ze geen prognoses uit het informatiesysteem tot hun beschikking zouden hebben. Verondersteld wordt dat leerlingen in dat geval hun keuze zouden baseren op de huidige arbeidsmarktsituatie. Daarom wordt de situatie in het basisjaar als referentieprognose gehanteerd. Deze Same As Before prognose (SAB) veronderstelt dat er tussen het basisjaar en het prognosejaar geen veranderingen zullen optreden. In sommige gevallen is de Same As Before prognose echter niet zo zinvol als referentie. Dit is bijvoorbeeld het geval bij de vervangingsvraag. Het is immers niet aannemelijk dat leerlingen op de hoogte zijn van de omvang van de vervangingsvraag op dat moment. In dit geval is het meer plausibel om de gemiddelde voorspelde vervangingsvraag als percentage van het aantal werkzame personen te gebruiken als een referentie-prognose voor de vervangingsvraag per beroep of opleiding.

Een laatste punt van afweging is de schaal waarop de prognoses geëvalueerd worden. In het kader van de studie- en beroepskeuze is het vooral van belang een goede inschatting te maken van de relatieve positie van een beroep of opleiding en gaat het niet in de eerste plaats om de absolute omvang van een bepaalde grootheid. Daarom wordt de evaluatie in dit rapport doorgaans naast de absolute prognoses ook uitgevoerd op een prognose die gecorrigeerd is voor het totale volumeeffect. Dat wil zeggen, de prognoses zijn vermenigvuldigd met een factor zodanig dat de totale omvang gelijk is aan de realisatie. Deze prognoses worden aangeduid als de relatieve prognoses.

\subsection{De oorzaak van voorspelfouten}

Het gemiddeld verlies en de score die in de vorige paragraaf zijn besproken, geven informatie over de kwaliteit van de gemaakte voorspellingen. Op zich geven zij echter niet aan waardoor een prognose goed of slecht is uitgevallen. Op deze wijze wordt derhalve niet duidelijk hoe de prognosemethodiek op grond van de evaluatie-resultaten kan worden aangepast. Dit is echter volgens Granger en Newbold (1986) het derde belangrijke punt bij het uitvoeren van een objectieve evaluatie. Om op basis van deze evaluatie conclusies te kunnen trekken die inzicht geven in de aard van de problemen die bij de prognoses verwacht kunnen worden en om consequenties met betrekking tot de gehanteerde methodiek te kunnen trekken, worden in aanvulling op de evaluatiemaatstaf, enkele tests uitgevoerd die informatie verschaffen over de oorzaken van de gemaakte voorspelfouten.

\section{Concentratie van voorspelfouten}

De evaluatiemaatstaf uit de vorige paragraaf geeft aan wat de gemiddelde voorspelfout van alle beroepen of alle opleidingen is. Om inzicht te krijgen in de oorzaken van deze voorspelfouten zal gekeken worden naar de voorspelfout in bepaalde soorten bedrijfssectoren, beroepsklassen of opleidingstypen. Er zijn drie soorten indelingen die in aanmerking komen voor een dergelijke benadering. Ten eerste kan gekeken worden naar de voorspelkwaliteit van iedere opleiding of ieder beroep afzonderlijk. Een nadeel van deze aanpak is dat op deze wijze het toevalskarakter van voorspelfouten niet meer aan het licht kan komen. ledere voorspelfout wordt als een incident op zich beschouwd waardoor de structuur achter deze voorspelfouten verloren gaat. De bruikbaarheid 
van deze informatie voor een objectieve evaluatie is niet zo groot, maar conform de benadering van Granger en Newbold (1986) kan een overzicht van alle afzonderlijke voorspelfouten nuttig zijn voor een subjectieve evaluatie. De zeer grote uitschieters komen hierbij immers aan het licht, waarbij er kan worden gekeken of er incidentele oorzaken voor de voorspelfout van bepaalde prognoses kunnen worden aangegeven. Om deze reden zullen de tabellen per beroep en opleiding wel worden opgenomen. Daarbij zal alleen het individuele verlies berekend worden en niet de score, omdat deze score uiterst gevoelig is voor een (toevallig) goede voorspelkwaliteit van de referentieprognose.

Een tweede wijze om de beroepen of opleidingen in te delen is een inhoudelijke indeling, dat wil zeggen een indeling op basis van de aard van de bedrijfssector, de beroepsklasse of het opleidingstype. Zo kan bij de evaluatie van opleidingen bijvoorbeeld gekeken worden of de voorspelfouten verschillen per opleidingsniveau.

Een derde indelingswijze betreft criteria op basis van de bij de prognose van de desbetreffende beroepsklasse of het opleidingstype gevolgde methodiek. In een aantal gevallen is voor verschillende beroepen of opleidingen een verschillende prognosemethodiek gehanteerd. Het is in zulke gevallen zeer interessant te bekijken of er tussen deze methodieken verschillen bestaan in de voorspelkwaliteit. Wel moet men zich hierbij realiseren dat de keuze voor een bepaalde prognosemethodiek niet willekeurig plaats zal hebben gevonden. Er waren destijds argumenten om voor een bepaald beroep of opleiding de ene methodiek te volgen en voor een ander beroep of opleiding een andere methodiek. Er kan dus sprake zijn van selectiviteit, waardoor de evaluaties per methodiek een vertekening kunnen vertonen.

\section{Verklaring van voorspelfouten}

Het verschil tussen de prognoses en de realisaties kan het beste beschouwd worden als de realisatie van een stochastische grootheid. Op het moment dat de prognose wordt gemaakt is immers - op zijn minst vanuit het gezichtspunt van de voorspeller - onvoorspelbaar hoe groot de voorspelfout zal zijn. Voor evaluatiedoeleinden is het interessant inzicht te hebben in de verdeling die deze toevalsvariabele heeft. In de empirische evaluatie in hoofdstuk 4 zal hiervan een schatting worden gemaakt. Uitgangspunt hierbij is dat de voorspelfouten normaal verdeeld zijn met verwachting $0^{17}$. De enige parameter die dan nog onbekend is, is de standaardafwijking van deze verdeling. Om inzicht te krijgen in de aard van de voorspelfouten wordt deze standaardafwijking geschat als functie van enkele verklarende variabelen:

(4) $\epsilon_{i}=x_{i}-\hat{x}_{i} \sim N\left(0, \sigma_{i}\right)$

met

(5) $\sigma_{i}=\left(x_{i}\right)^{\alpha} e^{Z_{i} \beta}$

Hierin is $x_{i}$ wederom de grootte van de te voorspellen grootheid (bijvoorbeeld beroepsklasse of opleidingstype) in het prognosejaar (1992) en $Z_{i}$ zijn de andere verklarende variabelen voor de

17. In Borghans (1993, hoofdstuk 7) wordt getoond dat voor een zinvolle benadering van dit probleem de aanname dat de voorspelfouten verwachting 0 hebben onvermijdelijk is. Overigens is bij de relatieve grootheden per definitie aan deze aanname voldaan. 
standaardafwijking van de prognoses. De eerste factor in vergelijking (5), de grootte van het beroep of de opleidingscategorie, is opgenomen om het schaal-effect te bepalen. Er kan verwacht worden dat grotere beroepsklassen of opleidingstypen ook te maken hebben met grotere voorspelfouten, maar waarschijnlijk zal deze voorspelfout niet volledig proportioneel toenemen. $\alpha$ zal dus waarschijnlijk kleiner zijn dan 1 en groter dan 0 . De keuze van de overige verklarende variabelen voor de omvang van de standaarddeviatie van de voorspelfouten hangt af van de grootheid die in beschouwing wordt genomen. Vergelijkbaar met de in de vorige subparagraaf gemaakte indeling kan hierbij zowel gedacht worden aan inhoudelijke variabelen als aan variabelen die te maken hebben met de gehanteerde methodiek.

Het informatiesysteem onderwijs-arbeidsmarkt bevat, zoals reeds eerder in aangegeven, ook zogenaamde risico-indicatoren. Deze indicatoren zijn mede bedoeld om een beeld te geven van de gevoeligheid van een bepaalde beroepsklasse of een opleidingstype voor exogene invloeden. Er kan dus verwacht worden dat er een samenhang bestaat tussen deze risico-indicatoren en de omvang van de voorspelfout. De methode op basis van (4) en (5) kan daardoor ook gebruikt worden om deze risico-indicatoren indirect te evalueren.

De vorm van (5) is gekozen om te verzekeren dat de standaardfout altijd positief is. De schatting van (4) en (5) vindt plaats met de maximum likelihood methode.

\section{Over- of onderschatting van veranderingen}

Een belangrijke component in prognoses is veelal de trend in de te voorspellen grootheid. Een cruciaal punt bij het extrapoleren van bestaande trends is de wijze waarop deze extrapolatie plaats dient te vinden. Het zonder meer doortrekken van trends leidt vaak, zeker op de langere termijn, tot onwaarschijnlijke resultaten. In dat geval wordt de trend helemaal niet opgenomen in de prognose, of wordt er een aanpak gekozen waarbij de invloed van de trend afneemt in de loop van de tijd. Vergelijkbare problemen doen zich in principe voor bij iedere verklarende variabele. Als een schatting van een parameter toevallig hoog uitvalt, zal men de invloed van deze variabele blijven overschatten, zodat er vaak bij niet significante waardes van de parameterschatting gekozen wordt voor het negeren van de parameter bij het opstellen van de prognose.

Een evaluatie is een geschikt middel om te bekijken in hoeverre de geschatte invloeden van de exogene variabelen in het verleden op een juiste manier zijn doorgetrokken naar de toekomst. Een te voorzichtige extrapolatie staat bekend als een onderschatting van verandering, terwijl een overdreven extrapolatie een overschatting van verandering is (zie Theil, 1958, blz. 68 en Borghans, 1993, hoofdstuk 10). Door het schatten van de volgende vergelijking is het vrij eenvoudig om te toetsen voor over- of onderschatting van veranderingen:

(6) $x_{i}-\hat{x}_{i}=\theta\left(\hat{x}_{i}-x_{i}^{\text {ref }}\right)+\epsilon$

waarin $x_{i}^{\text {ref }}$ de al eerder genoemde referentie-prognose is, waarbij geen veranderingen verwacht worden. Op basis van deze vergelijking is het mogelijk een verwachting van het verschil tussen de realisatie en de prognose te formuleren. De rechterkant van regressievergelijking (6) bevat alleen grootheden die bekend waren op het moment dat de prognose werd opgesteld. Daardoor zou het 
destijds in principe mogelijk zijn geweest een verbeterde prognose op te stellen die deze over- of onderschatting van veranderingen niet bevatte. Figuur 3.1 geeft aan wat de betekenis is van bepaalde parameterwaarden van $\theta$. In de figuur is verondersteld dat de prognose hoger uitvalt dan de waarde van de grootheid in het basisjaar. Het omgekeerde is echter ook mogelijk. Dan ontstaat een situatie die het spiegelbeeld is van de in figuur 3.1 geschetste situatie.

Figuur 3.1. De mogelijke waarden van de overschattingscoëfficiënt $\theta$ bij een over- of onderschatting van veranderingen

realisatie:

$\theta>0 \times$ onderschatting van verandering

prognose $\theta=0$

$-1<\theta<0 \quad x \quad$ overschatting van verandering

situatie basisjaar

$\theta=-1$

$\theta<-1 \quad \times \quad \begin{aligned} & \text { richting feitelijke verandering } \\ & \text { tegengesteld aan feitelijke verandering }\end{aligned}$

In de figuur zijn drie gebieden te onderscheiden met twee grenswaarden. Als $\theta=0$ dan is gemiddeld genomen de realisatie gelijk aan de prognose. De kwaliteit van de prognose kan dan weliswaar nog slecht zijn, maar er vindt geen systematische over- of onderschatting van de veranderingen plaats. Als $\theta>0$ dan ligt de realisatie van de voorspelde grootheid gemiddeld verder van de waarde in het basisjaar af dan de prognose. $\mathrm{Er}$ is dan dus een onderschatting van veranderingen. Omgekeerd betekent $\theta<0$ dat de realisatie gemiddeld dichter bij de waarde in het basisjaar ligt dan de prognose. $\mathrm{Er}$ is dan dus sprake van een overschatting van veranderingen. Hierbij wordt verondersteld dat $\theta>-1$. Als $\theta=-1$ dan is de overschatting van veranderingen totaal. Dat wil zeggen dat in dat geval iedere voorspelde verandering geen informatieve waarde had en men net zo goed de referentieprognose als prognose had kunnen hanteren. Als $\theta$ kleiner is dan -1 , dan is er zelfs sprake van een omkeringseffect. Dit betekent dat daar waar dalingen werden voorspeld er gemiddeld sprake was van een stijging, terwijl bij voorspellingen van stijgingen gemiddeld er een daling is opgetreden.

Een overschatting van veranderingen hoeft niet alleen veroorzaakt te zijn door het te ver doortrekken van trends, maar is vaak het gevolg van een grote storingscomponent in de prognoses. Als prognoses naast een informatief gedeelte ook ruis bevatten kan het zinvol zijn de voorspelde veranderingen gedeeltelijk te negeren. Hoe groter deze storingscomponent des te voorzichtiger men zou moeten zijn met het hanteren van de prognoses. In (6) komt dit tot uitdrukking door een waarde van $\theta$ die dicht bij -1 ligt. 


\subsection{De evaluatie van kwalitatieve typeringen}

De geschetste evaluatiemethode had tot nog toe betrekking op de puntvoorspellingen die voortkomen uit de prognosemodellen van het informatiesysteem. Zoals gezegd heeft de uiteindelijke presentatie van de prognoses echter plaats gevonden door middel van een kwalitatieve typering van de prognoseresultaten.

De meest directe manier om deze kwalitatieve typeringen te evalueren is door de ontwikkelingen die feitelijk hebben plaatsgevonden, volgens hetzelfde indelingsschema ook te voorzien van een kwalitatieve typering en na te gaan in hoeveel gevallen de oorspronkelijke typering overeenkomt met deze realisatie (zie ook De Grip, Heijke en Berendsen, 1991). Een dergelijke evaluatie wordt gemaakt op basis van een matrix waarbij de oorspronkelijke typering en de realisatie tegen elkaar worden afgezet. Bij een dergelijke evaluatie wordt echter gelijktijdig de voorspelkwaliteit van de prognoses als de wijze van typeren geëvalueerd. Omdat in de voorgaande paragrafen, op basis van de puntprognoses, reeds een methodiek beschreven is om de voorspelkwaliteit te evalueren, wordt in dit rapport bij de evaluatie van de kwalitatieve typeringen vooral gekeken naar de wijze van indelen.

Zoals beschreven in paragraaf 2.10 wijkt de gehanteerde methodiek van typeren af van de in de statistiek gebruikelijke betrouwbaarheidsintervallen, doordat de grenzen van de kwalitatieve typeringen onafhankelijk zijn van de afzonderlijke prognoses. Zoals gezegd zijn er daarbij twee belangrijke afwijkingen. Ten eerste hoeft de puntvoorspelling bij de gevolgde aanpak niet in het midden van het betrouwbaarheidsinterval te liggen, waardoor de kans op een juiste typering kleiner wordt. Ten tweede bevat de typeringsmethodiek twee extreme typeringen waarbij het typeringsinterval aan een zijde onbegrensd is. Hierdoor is de kans op een juiste typering bij deze extreme typeringen juist groter omdat voorspelfouten nooit tot een foute typering zullen leiden, indien de realisatie nog extremer is dan de prognose.

Formule (4) en (5) gaven een verklaring voor de standaarddeviatie van de voorspelfouten. Om de betrouwbaarheid van de gekozen intervallen te bepalen en de effecten van de wijze van typeren te kunnen inventariseren, wordt op basis van deze standaarddeviatie voor iedere afzonderlijke prognose de kans berekend dat de realisatie in hetzelfde interval terechtkomt als de prognose. Dit gebeurt op drie manieren. Ten eerste wordt de kans op een juiste typering bepaald onder de aanname dat er een symmetrisch interval zou zijn gehanteerd. Deze kans is gelijk aan de oppervlakte onder de kansverdeling aangegeven in figuur 2.4 (a). Hierbij wordt de intervallengte gebruikt die in het informatiesysteem ook voor de desbetreffende prognose is gebruikt. Omdat deze intervallengte voor de twee extreme typeringen ('erg laag' en 'erg hoog') onbegrensd is, is voor deze gevallen de intervallengte gelijk gesteld aan de lengte van de aangrenzende typeringen ('laag' en 'hoog').

Vervolgens wordt gekeken naar de kans dat prognose en realisatie in hetzelfde interval vallen als de intervalgrenzen willekeurig ten opzichte van de prognose zijn gepositioneerd. Deze kans is niet bepaald op basis van de standaarddeviatie, maar op grond van de feitelijke voorspelfout. De 
onderlinge verhouding tussen de voorspelfout en de lengte van het interval bepaalt, bij een willekeurige positionering van de prognose binnen het interval, de kans op een juiste typering. Omdat deze kans is gebaseerd op gerealiseerde voorspelfouten en niet op de kansverdeling, is per afzonderlijke prognose een vergelijking met de kans op een juiste typering bij een symmetrisch interval niet goed mogelijk. Wel kunnen de gemiddelde kansen over alle prognoses laten zien in hoeverre de trefzekerheid is teruggelopen vanwege de asymmetrische intervallen. Verder is de kans op een juiste typering bij deze wijze van meten gelijk aan 0 als de voorspelfout groter is dan de intervallengte. Het aantal malen dat deze kans 0 voorkomt geeft daardoor een indicatie voor de bruikbaarheid van de gehanteerde intervallengte.

Ten derde wordt, wederom op basis van de kansverdeling van de voorspelfout, de kans bepaald dat bij de feitelijk gekozen intervalgrenzen een juiste typering heeft plaatsgevonden. Bij deze feitelijke kans speelt zowel de negatieve invloed van de assymetrie alsook de positieve invloed vanwege de onbegrensde hoekintervallen een rol. 


\section{DE EMPIRISCHE EVALUATIE}

\subsection{Inleiding}

In dit hoofdstuk vindt de empirische evaluatie plaats van de prognoses die in 1989 zijn gemaakt voor de eerste versie van het informatiesysteem onderwijs-arbeidsmarkt dat betrekking had op de volle breedte van het onderwijs. Hierbij wordt zoveel mogelijk de systematiek die beschreven is in het vorige hoofdstuk gehanteerd. Zoals reeds werd opgemerkt is het op bepaalde punten niet mogelijk de prognoses van het informatiesysteem empirisch te evalueren. Om deze reden bevat dit hoofdstuk geen evaluatie van de uitbreidingsvraag per opleidingstype en de aanbodprognoses per opleidingstype. Naast de prognoses van het ROA worden ook de prognoses die als invoer voor het informatiesysteem fungeerden getest. Dit hoofdstuk bevat daarom een paragraaf over de bedrijfssectorprognoses van het CPB en in de paragraaf over het aanbod wordt gekeken naar de voorspelkwaliteit van de onderwijsprognoses van Skill.

\subsection{Bedrijfssectorprognoses CPB}

De uitbreidingsvraagprognoses zijn voor een belangrijk deel gebaseerd op de bedrijfssectorprognoses van het CPB. Omdat de kwaliteit van deze prognoses in hoge mate de kwaliteit van de prognoses per beroepsklasse en per opleidingstype kan bepalen, worden in deze paragraaf de CPBprognoses onder de loep genomen.

\section{De voorspelfout}

De bedrijfssectorprognoses die gebruikt zijn voor de uitbreidingsvraagprognoses zijn afkomstig van de bedrijfstakverkenningen van het CPB op basis van het beta-model (Eijgenraam en Verkade, 1988). Thans is dit model niet meer in gebruik en worden de bedrijfssectorprognoses gebaseerd op het Athena-model. Omdat het CPB in 1988 niet beschikte over prognoses tot 1992 zijn de wel beschikbare prognoses tot 1990, mede op aanwijzing van het CPB, geëxtrapoleerd tot en met 1992.

Het CPB maakt voorspellingen van de werkgelegenheid per bedrijfssector in arbeidsvolumes, gebaseerd op de data-reeksen van de Nationale Rekeningen. Daar voor de uitbreidingsvraagprognoses, vanwege de verbijzondering naar opleidingstype en beroepsklasse, gebruik gemaakt wordt van data-materiaal uit de AKT en (tegenwoordig) de EBB, dat betrekking heeft op aantallen werkzame personen, moeten de arbeidsvolumecijfers van het $C P B$ vertaald worden naar aantallen werkzame personen. Deze omzetting vindt plaats op basis van CPB-prognoses over de verhouding tussen beide grootheden, de zogenaamde P/A-ratio.

Ondanks deze omrekening blijft er echter een verschil bestaan tussen de gegevens van de Nationale Rekeningen en de AKT of EBB. Tabel 4.1 geeft aan hoe groot deze verschillen in 1985 waren. In een aantal bedrijfssectoren is het verschil tussen beide data-bronnen zeer aanzienlijk. Bij de overheid bevat de AKT 14\% minder personen dan bij de Nationale Rekeningen en bij de basismetaalindustrie 
is de AKT juist $15 \%$ groter. De geconstateerde verschillen zijn ontstaan als gevolg van andere definities en een andere wijze van classificeren.

Tabel 4.1. Discrepanties tussen de aantallen werkzame personen in 1985 op grond van AKT en Nationale Rekeningen

Bedrijfssector

AKT

Nationale verschil $\quad \%$
Rekeningen

Landbouw visserij en bosbouw

Voedings- en genotmiddelenindustrie

Textiel, kleding-, en leder- en schoenindustrie

Hout- en bouwmaterialenindustrie

Papier- en grafische industrie

Chemische, rubber- en kunststof-verwerkende industrie

Basismetaalindustrie

Metaalprodukten- en optische industrie

Electronische industrie

Transportmiddelenindustrie

Aardolie-industrie

Delfstoffenwinning

Openbare nutsbedrijven

Bouwnijverheid en woningbezit

Handel

Zee- en luchtvaart

Overige transport-, opslag- en communicatiebedrijven

Bank- en verzekeringswezen

Overige tertiaire diensten

Medische en veterinaire diensten

Overige kwartiaire diensten

Overheid

$\begin{array}{rrrr}265.000 & 268.000 & -3.000 & -1,2 \\ 165.000 & 166.000 & -1.000 & -0,7 \\ 55.000 & 56.000 & -1.000 & -0,8 \\ 73.000 & 73.000 & 0 & -0,4 \\ 108.000 & 115.000 & -7.000 & -5,8 \\ 115.000 & 112.000 & 3.000 & 3,0 \\ 39.000 & 33.000 & 6.000 & 15,0 \\ 255.000 & 254.000 & 1.000 & 0,3 \\ 100.000 & 101.000 & -1.000 & -0,5 \\ 71.000 & 71.000 & 0 & 0,5 \\ 10.000 & 10.000 & 0 & -0,2 \\ 11.000 & 11.000 & 0 & -0,3 \\ 44.000 & 44.000 & 0 & -0,1 \\ 415.000 & 417.000 & -2.000 & -0,4 \\ 702.000 & 720.000 & -18.000 & -2,6 \\ 50.000 & 51.000 & -1.000 & -1,2 \\ 267.000 & 272.000 & -5.000 & -1,7 \\ 188.000 & 186.000 & 2.000 & 1,0 \\ 550.000 & 561.000 & -11.000 & -2,0 \\ 374.000 & 375.000 & -1.000 & -0,2 \\ 429.000 & 427.000 & 2.000 & 0,5 \\ 688.000 & 781.000 & -93.000 & -13,5\end{array}$

Bij het opstellen van prognoses moet uiteraard rekening worden gehouden met deze discrepantie tussen de databestanden, maar zelfs na een correctie blijft het verschil tussen de twee gegevensbronnen een potentiële bron van onnauwkeurigheid. Later in deze paragraaf zal daarom bekeken worden of deze discrepantie een significante invloed op het voorspellingsresultaat heeft.

In de uitbreidingsvraagprognoses zijn 22 bedrijfssectoren onderscheiden. Tabel 4.2 geeft een overzicht van de werkgelegenheid per bedrijfssector in 1985, de prognoses voor 1992 en de realisatie hiervan in 1992. Bovendien bevat de tabel de voorspelfout. Op grond van deze voorspelfout is het individueel verlies bepaald.

Het grootste voorspelverlies werd gemaakt bij de delfstoffenwinning. Het CPB voorspelde een groei van de werkgelegenheid in deze bedrijfssector van $8 \%$, maar in werkelijkheid liep de werkgelegenheid terug met $18 \%$. Ook bij de overige tertiaire diensten, de medische en veterinaire diensten, de papier- en grafische industrie, de textielindustrie, de overige kwartaire diensten en de overheid is het verlies relatief groot. In deze bedrijfssectoren valt de groei van de werkgelegenheid 
$-54-$

in de realisatie veel groter uit dan werd voorspeld. Bij de overige tertiaire diensten voorspelde het CPB voor de periode 1985-1992 een werkgelegenheidsgroei van $21 \%$, terwijl de groei feitelijk $65 \%$ was. Deze bedrijfssector bevat echter ook het uitzendwezen, waardoor er ongetwijfeld sprake zal zijn van veel kleine banen. In totaal zijn er in 1992171 duizend banen onder de twaalf-uren-grens. Ook in de medische sector was de voorspelling van $(+13 \%)$ lager dan de realisatie $(+44 \%)$. Bij de papier en grafische industrie werd een groei van $22 \%$ voorspeld, terwijl er achteraf een groei van $54 \%$ werd geconstateerd. Bij de overige kwartaire diensten was de prognose $+10 \%$ en de realisatie $+34 \%$. Bij de overheid, tenslotte, werd een groei van $18 \%$ voorspeld, terwijl de groei feitelijk $39 \%$ bedroeg. Wellicht bestaat er met betrekking tot (semi-loverheidssectoren een neiging om op grond van beleidsvoornemens de toekomstige werkgelegenheidsgroei te onderschatten. Het is echter onduidelijk in hoeverre de hoge waargenomen groeipercentages een gevolg zijn van de omschakeling van AKT naar EBB en welke rol de kleine banen in deze groei spelen.

Tabel 4.2. Voorspelfouten bij de CPB-prognoses van het aantal werkenden per bedrijfssector

\begin{tabular}{|c|c|c|c|c|c|}
\hline Bedrijfssector & $\begin{array}{r}\text { aantal } \\
1985\end{array}$ & $\begin{array}{l}\text { prognose } \\
1992\end{array}$ & $\begin{array}{c}\text { realisatie } \\
1992\end{array}$ & voorspelfout & verlies \\
\hline Landbouw, visserij en bosbouw & 265.000 & 266.000 & 259.000 & 7.000 & 0,0008 \\
\hline Voedings- en genotm. industrie & 165.000 & 172.000 & 178.000 & -6.000 & 0,0010 \\
\hline $\begin{array}{l}\text { Textiel, kleding-, en leder } \\
\text { en schoenindustrie }\end{array}$ & 55.000 & 58.000 & 50.000 & 8.000 & 0,0302 \\
\hline Hout- en bouwmaterialenind. & 73.000 & 79.000 & 80.000 & -1.000 & 0,0001 \\
\hline $\begin{array}{l}\text { Papier- en grafische ind. } \\
\text { Chemische, rubber- en kunst- }\end{array}$ & 108.000 & 132.000 & 166.000 & -34.000 & 0,0414 \\
\hline stof-verwerkende ind. & 115.000 & 134.000 & 144.000 & -10.000 & 0,0048 \\
\hline Basismetaalindustrie & 39.000 & 35.000 & 31.000 & 4.000 & 0,0136 \\
\hline $\begin{array}{l}\text { Metaalprodukten- en optische } \\
\text { ind. }\end{array}$ & 255.000 & 281.000 & 322.000 & -41.000 & 0,0162 \\
\hline Electrotechnische ind. & 100.000 & 107.000 & 115.000 & -8.000 & 0,0054 \\
\hline Transportmiddelenindustrie & 71.000 & 73.000 & 71.000 & 2.000 & 0,0005 \\
\hline Aardolie-industrie & 10.000 & 10.000 & 10.000 & 0 & 0,0001 \\
\hline Delfstoffenwinning & 11.000 & 12.000 & 9.000 & 3.000 & 0,0944 \\
\hline Openbare nutsbedrijven & 44.000 & 46.000 & 46.000 & 0 & 0,0000 \\
\hline Bouwnijverheid en woningbezit & 415.000 & 448.000 & 430.000 & 18.000 & 0,0017 \\
\hline Handel & 702.000 & 862.000 & 978.000 & -116.000 & 0,0141 \\
\hline Zee- en luchtvaart & 50.000 & 60.000 & 56.000 & 4.000 & 0,0033 \\
\hline $\begin{array}{l}\text { Overige transport-, opslag- } \\
\text { en communicatiebedrijven }\end{array}$ & 267.000 & 312.000 & 350.000 & -38.000 & 0,0121 \\
\hline Bank- en verzekeringswezen & 188.000 & 207.000 & 229.000 & -22.000 & 0,0087 \\
\hline $\begin{array}{l}\text { Overige tertiaire diensten } \\
\text { Medische en veterinaire }\end{array}$ & 550.000 & 666.000 & 908.000 & -242.000 & 0,0709 \\
\hline diensten & 374.000 & 423.000 & 537.000 & -114.000 & 0,0454 \\
\hline Overige kwartaire diensten & 429.000 & 475.000 & 573.000 & -98.000 & 0,0299 \\
\hline Overheid & 688.000 & 809.000 & 952.000 & -143.000 & 0,0225 \\
\hline
\end{tabular}


Tabel 4.3. Totaal-overzicht voorspelkwaliteit bedrijfssectorprognoses

\begin{tabular}{|c|c|c|c|}
\hline Methode & gem. verlies prognose & gem. verlies SAB & score \\
\hline Absoluut & 0,0254 & 0,0699 & 0,36 \\
\hline Relatief & 0,0120 & 0,0256 & 0,47 \\
\hline Agr./industrie, absoluut & 0,0112 & 0,0317 & 0,35 \\
\hline Diensten, absoluut & 0,0296 & 0,0811 & 0,36 \\
\hline Agr./industrie, relatief & 0,0191 & 0,0561 & 0,34 \\
\hline Diensten, relatief & 0,0099 & 0,0166 & 0,59 \\
\hline
\end{tabular}

\section{De voorspelkwaliteit}

Men moet echter, zoals reeds werd opgemerkt in paragraaf 1.2 , voorzichtig zijn met het interpreteren van afzonderlijke voorspelfouten. Er zijn achteraf altijd redenen te bedenken waarom in een concreet geval de realisatie anders uitvalt dan de prognose. Belangrijker is daarom de confrontatie van de prognoses met de realisaties in zijn totaliteit. Tabel $4.3 \mathrm{geeft}$ hiervan een beeld. In de tabel wordt de voorspelkwaliteit van de gehanteerde prognoses op basis van het gemiddelde verlies (formule 2) vergeleken met de Same As Before prognose (SAB). In de eerste rij worden beide prognoses rechtstreeks met elkaar vergeleken. Het gemiddeld verlies van de CPB-prognose is aanmerkelijk lager dan bij de SAB. Dit betekent dat de CPB-prognose slechts $36 \%$ van de fout van $S A B$ bevat. Dit lijkt een behoorlijk goed voorspelresultaat. Zowel de kwaliteit van de CPB-prognose als van $S A B$ wordt sterk verminderd doordat de totale werkgelegenheid niet juist is voorspeld. Deze 'fout' is zoals gezegd ook mede het gevolg van de wijze waarop de werkgelegenheid is gemeten.

Voor studie- en beroepskeuze is echter vooral de onderlinge verhouding van belang, omdat het vanuit het perspectief van de student gaat om een keuze tussen de bestaande alternatieven. Voorspelfouten met betrekking tot de ontwikkeling van de gehele markt doen er daarom vanuit hun gezichtspunt minder toe. De tweede rij bevat de voorspelkwaliteiten van deze relatieve prognoses. Doordat SAB per definitie totaal geen groeivoorspelling bevat en de CPB-prognose deze groei slechts onderschatte vermindert de fout bij SAB meer dan bij de CPB-prognose. De score van de bedrijfssector-prognose vergeleken met SAB komt daarom nu uit op $47 \%$. Overigens moet bij deze resultaten de kanttekening worden geplaatst dat de CPB-prognoses gebaseerd zijn op feitelijke informatie tot en met 1988. Dit in tegenstelling tot de overige onderdelen van het informatiesysteem, waarbij de laatst bekende gegevens op 1985 betrekking hadden.

Vervolgens geeft tabel 4.3 de voorspelfout aan, verdeeld over aan de ene kant de agrarische en industriesectoren en aan de andere kant de tertiaire en kwartaire sectoren. In absolute aantallen bevatten beide deelgebieden ongeveer een even grote voorspelfout. Voor een groot deel is dit veroorzaakt door de grote onderschatting van de groei van de dienstensectoren in het algemeen. Door naar de relatieve cijfers te kijken wordt de prestatie bij de dienstensectoren vergeleken met 
SAB aanzienlijk minder gunstig. Daarentegen blijken de prognoses voor de agrarische sector en de industrie bij de relatieve prognoses iets beter te zijn.

\section{Een verklaring van de voorspelfout}

Tabel 4.4 geeft de resultaten van een verklaring van de standaarddeviatie van de voorspelfouten van de bedrijfssectorprognoses. Ter verklaring hiervan is allereerst een schaalvariabele opgenomen die de omvang van de bedrijfssector weergeeft. Daarnaast bestaat de verklaring van de standaarddeviatie van de prognosefouten uit een indicator die aangeeft of de betreffende bedrijfstak tot de agrarische of industriële groep gerekend kan worden en uit een variabele die de relatieve discrepantie tussen de cijfers uit de Nationale Rekeningen en de AKT uitdrukt. De sector dummy is opgenomen om, vergelijkbaar met tabel 4.3, structurele verschillen tussen de twee hoofdsectoren van de economie op te sporen. De tweede variabele, het verschil tussen beide databronnen, zou een verklaring kunnen geven voor de voorspelfout, omdat prognoses uit de Nationale Rekeningen zijn gehanteerd om EBB-cijfers te voorspellen. Hoe verder deze cijfers uiteenlopen hoe moeilijker het zal zijn deze adequate prognoses op te stellen.

Tabel 4.4. Een verklaring van de standaarddeviatie van de voorspelfouten

Variabele parameter t-waarde

$\begin{array}{lrr}\text { Schaal } & 0,62 & 5,58 \\ \text { Constante } & -2,80 & 1,97 \\ \text { Agr/industrie } & -0,22 & 0,66 \\ \text { Verschil Nat.Rek.-AKT } & 0,01 & 0,57\end{array}$

De geschatte waarde van de schaal-parameter is 0,62 . Dit impliceert dat de voorspelfout minder dan proportioneel met de bedrijfssectoromvang toeneemt. Uit tabel 4.4 valt verder op te maken dat de voorspelfout in de agrarische sector en de industrie inderdaad kleiner is en dat de discrepantie tussen de Nationale Rekeningen en de AKT inderdaad de verwachte invloed op de voorspelfout heeft. Beide effecten zijn echter niet significant. Men moet derhalve voorzichtig zijn op basis hiervan conclusies te trekken.

\section{Onderschatting van veranderingen}

Als laatste onderdeel van de empirische evaluatie van de bedrijfssectorprognoses wordt in tabel 4.5 de mate waarin veranderingen zijn ondergeschat beschreven. Vanwege de onderschatting van de totale werkgelegenheidsontwikkeling is ook hier het onderscheid tussen de absolute en de relatieve maatstaf belangrijk. In beide gevallen is er sprake van een significante onderschatting van veranderingen. De onderschattings-coëfficiënt is ongeveer 1 wat betekent dat de waargenomen veranderingen gemiddeld ongeveer twee maal zo groot zijn als de veranderingen in de prognoses. Kennelijk is het CPB nogal voorzichtig geweest bij het opstellen van de werkgelegenheidsprognoses 
naar bedrijfssector.

Figuur 4.1. De onderschatting van veranderingen bij de CPB-bedrijfssectorprognoses (absoluut)

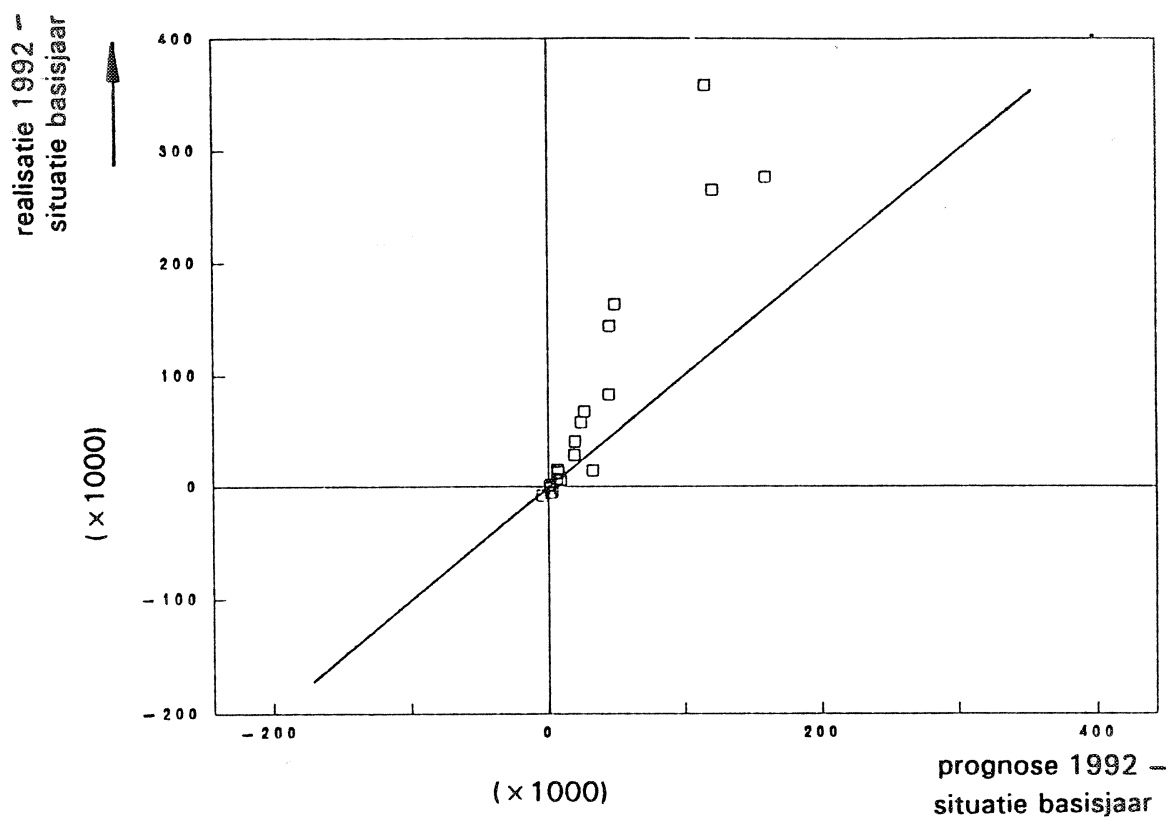

Figuur 4.1 geeft het verband aan tussen de voorspelde en de gerealiseerde verandering ten opzichte van het basisjaar, met de prognoses op de horizontale as en de realisaties op de verticale as. Als er geen onder- of overschatting van veranderingen is, dan zouden de waarnemingen rondom de $45 \%$-lijn liggen. Uit de figuur blijkt echter dat er duidelijk sprake is van een onderschatting van de feitelijke werkgelegenheidsgroei doordat de veranderingen in de realisatie systematisch hoger zijn dan de veranderingen in de prognoses. Figuur 4.2 geeft dezelfde informatie voor de relatieve prognoses, dus na correctie voor prognosefouten van het algemene groeipercentage. Het verband bij deze relatieve maat is minder duidelijk dan bij de absolute cijfers, maar er is nog steeds sprake van significante onderschatting van veranderingen.

Tabel 4.5. Onderschatting van verandering bij de bedrijfssectorprognoses 


\section{Verband tussen bedrijfssector- en beroepsklasseprognoses}

Centraal in deze paragraaf stonden de bedrijfssectorprognoses. De kwaliteit van deze gegevens is echter alleen van belang voor het informatiesysteem voorzover de voorspelfouten consequenties hebben voor de werkgelegenheidsprognoses per beroepsklasse, en de daarvan afgeleide werkgelegenheidsprognoses per opleidingstype. Om een beeld te krijgen van de relevantie van de voorspelfouten in de bedrijfssectorprognoses, wordt in tabel 4.6 een overzicht gegeven van de voorspelkwaliteit van de CPB-prognoses vertaald naar beroepsklassen.

Figuur 4.2. De onderschatting van veranderingen bij de CPB-bedrijfssectorprognoses (relatief)

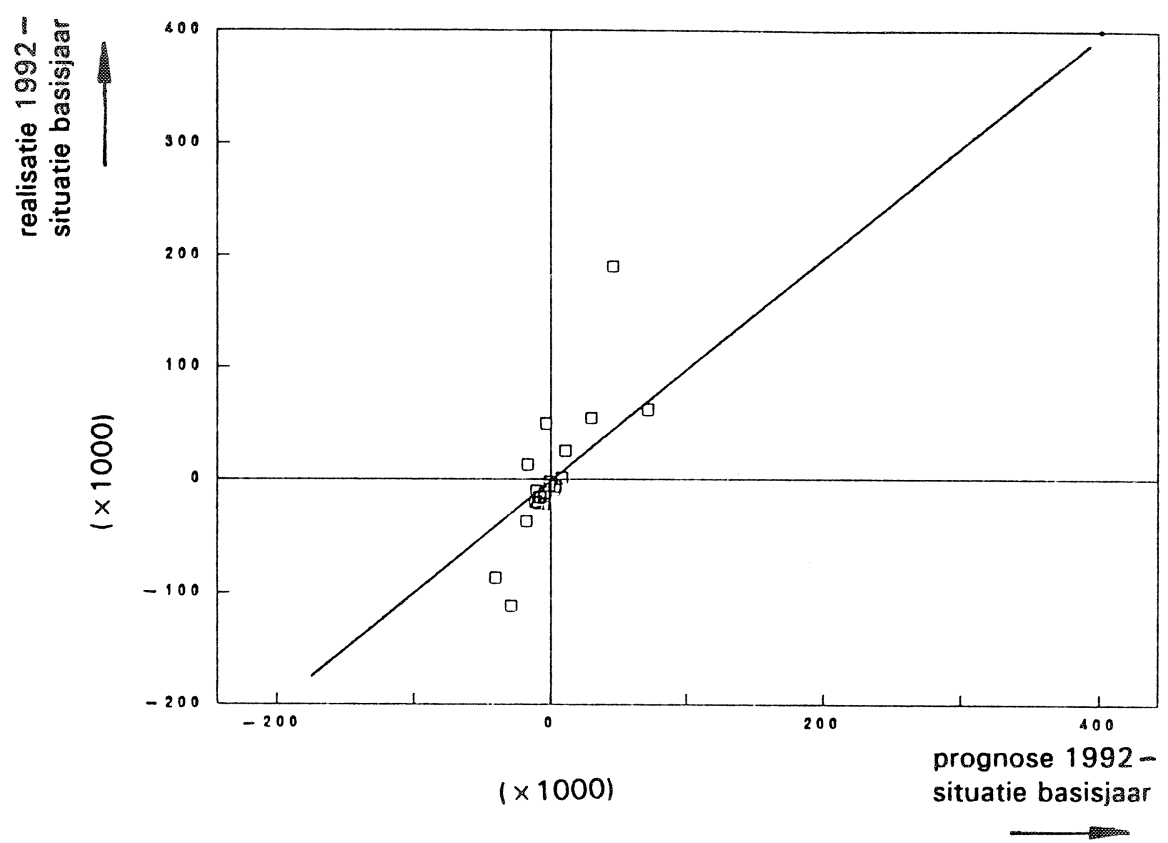

Om de invloed van de methodiek die is toegepast bij de beroepsklasseprognoses hierbij uit te schakelen, is de omzetting gebaseerd op het vaste-coëfficiënten-model. Daarbij zijn zowel op basis van de beroepenstructuur van de bedrijfssectoren in 1985 als op basis van de beroepenstructuur in 1992, de bedrijfssectorprognoses omgezet naar beroepsklasseprognoses. De tabel geeft voor beide structuur-matrices een overzicht van de voorspelresultaten op basis van de Same As Before prognose, de feitelijke prognose en de realisatie van de werkgelegenheid naar bedrijfssector.

De berekeningen op basis van de beroepenstructuur-matrix uit 1985 laten zien dat de prognose bij benadering dezelfde voorspelkracht heeft als in het geval zou worden uitgegaan van de feitelijke sector omvang in 1992. De scoreverhouding met SAB is $76 \%$. Dit is aanmerkelijk minder goed dan de $36 \%$ uit tabel 4.3 die volgde uit een directe evaluatie van de bedrijfssectorprognoses. Uit een beschouwing van het relatieve verlies bij de prognoses blijkt verder dat het verschil ten opzichte van de Same As Before prognose volledig werd veroorzaakt door een betere inschatting van het totale werkgelegenheidsniveau. Hoewel de bedrijfssectorprognoses op zich goede voorspellingen 
zijn, blijkt de toegevoegde waarde bij het gebruik van de structuur-matrix van 1985 afwezig te zijn.

Het tweede deel van de tabel laat zien dat indien de juiste structuur-matrix gebruikt zou zijn, de prognoseresultaten aanzienlijk verbeteren. Bij gebruik van de bedrijfssectorrealisaties van 1992 blijft er in dit geval - per definitie - geen voorspelfout meer over. De voorspelfout bij gebruik van de prognoses wordt meer dan gehalveerd. Dit betekent dat bij een vaste-coëfficiëntenaanpak $45 \%$ van de voorspelfouten bij beroepen is voortgekomen uit de bedrijfssectorprognoses en $55 \%$ van de fout veroorzaakt is door de onvoorziene wijzigingen in de beroepenstructuur van de bedrijfssectoren (uitgaande van de SAB-prognose zijn deze aandelen respectievelijk $73 \%$ en $27 \%$ ). Ook bij de relatieve maatstaf blijken vergelijkbare verhoudingen te gelden. Hieruit blijkt dat het van groot belang is bij de prognoses van de werkgelegenheid per beroepsklasse, rekening te houden met mogelijke wijzigingen van de beroepenstructuur.

Tabel 4.6. Kwaliteit van de bedrijfssectorprognoses omgezet naar beroepsklassen

$\begin{array}{llll}\text { Bedrijfssector- } & \text { structuur- } & \text { gemiddeld } & \text { gemiddeld } \\ \text { prognose } & \text { matrix } & \text { verlies (absoluut) } & \text { verlies (relatief) }\end{array}$

$\begin{array}{llll}\text { Basisjaar '85 (SAB) } & ' 85 & 0,1055 & 0,0767 \\ \text { Prognose '92 } & ' 85 & 0,0798 & 0,0771 \\ \text { Realisatie '92 } & ' 85 & 0,0806 & 0,0760 \\ & ' 92 & & \\ \text { Basisjaar '85 (SAB) } & ' 92 & 0,0775 & 0,0518 \\ \text { Prognose '92 } & ' 92 & 0,0358 & 0,0418 \\ \text { Realisatie '92 } & & 0 & 0\end{array}$

De score bij het vaste coëfficiëntenmodel is 1.01 bij gebruik van de structuurmatrix van 1985 en 0,54 bij de structuurmatrix van 1992. Verder blijft, zelfs bij het gebruik van de juiste beroepenstructuur, de score-prestatie van de bedrijfssectorprognoses op het niveau van beroepsklassen (absoluut $0,0358 \div 0,0775=0,46$ en relatief zelfs $0,0418 \div 0,0518=0,81$ ) slechter dan de score (respectievelijk 0,36 absoluut en 0,47 relatief) op bedrijfssectorniveau. Kennelijk hebben inderdaad enkele relatief slecht voorspelde bedrijfssectoren een belangrijke rol bij de omzetting van deze prognoses naar beroepsklassen.

\section{Conclusies}

Samenvattend kan gesteld worden dat de prognoses van het CPB die gebruikt zijn als invoergegevens voor de vraagzijde van het model een goede voorspelkwaliteit hebben. Een punt van aandacht hierbij blijft de aansluiting tussen de Nationale Rekeningen en de EBB. Verder valt te verwachten dat de nieuwe CBS-definitie van de werkzame bevolking door het uitsluiten van de banen die kleiner zijn dan 12 uur een kwaliteitsverbeterende invloed zal hebben, omdat het CPB primair arbeidsvolumes voorspelt en de vertaling naar werkzame personen vooral bij de kleine banen erg gevoelig is voor een juiste prognose van de P/A-ratio. Verder is deze groep van kleine banen 
$-60-$

waarschijnlijk niet erg relevant voor de hoofddoelgroep van de prognoses in het informatiesysteem - de leerlingen die hun studie- en beroepskeuze moeten maken. Wel kunnen deze kleine banen betekenis hebben voor de herintredingsproblematiek. Vertaald naar beroepsklassen is de voorspelkracht van de bedrijfssectorprognoses enigszins lager. Van de totale voorspelfout wordt - uitgaande van SAB op beroepenniveau - ongeveer tweederde veroorzaakt door verschuivingen tussen bedrijfssectoren en eenderde door veranderingen in de beroepenstructuur. Van dat tweederde deel van de potentiële voorspelfout nemen de bedrijfssectorprognoses van het CPB ongeveer de helft weg. Voor goede prognoses van de werkgelegenheid per beroepsklasse is een verklaring van de veranderende beroepenstructuur derhalve onontbeerlijk. Tenslotte is het opmerkelijk dat de bedrijfssectorprognoses de werkgelegenheidveranderingen sterk hebben onderschat. In latere evaluaties zal bekeken moeten worden of dit incidenteel is, of dat er sprake is van een structurele onderschatting van veranderingen.

\subsection{Uitbreidingsvraag per beroep}

In deze paragraaf wordt de doeltreffendheid van de prognoses met betrekking tot de uitbreidingsvraag per beroep empirisch getoetst. Tabel 4.7 bevat een overzicht van de 79 beroepenklassen waarvoor toentertijd een prognose is gemaakt. De tabel bevat achtereenvolgens het aantal werkzame personen in 1985, de prognose voor 1992 en de realisatie in 1992 en geeft vervolgens de voorspelfout en het verlies per beroep.

Tabel 4.7. Voorspelfouten van de uitbreidingsvraag per beroepsklasse ${ }^{18}$

$\begin{array}{lccccc}\text { CBS-beroepsklasse } & \text { aantal } & \text { prognose } & \text { realisatie } & \text { voorspelfout verlies } \\ 1985 & 1992 & 1992 & & \end{array}$

01 Schei-, natuurkundigen e.a. technici

02 Ingenieurs, tekenaars e.d.

04 Vliegtuig- en scheepsofficieren

05 Bioloog, biochemicus, landbouwkundige

06 Medisch- en paramedisch personeel

08 Wiskundigen, systeemanalisten e.d.

09 Econoom

11 Accountant, belastingconsulent

12 Jurist, notaris, rechter

13 Onderwijzend personeel

14 Theoloog, dominee, pastor e.d.

15 Journalist, auteur, redacteur e.d.

16 Kunstenaar, ontwerper, fotograaf filmer

17 Musicus, dirigent, toneelspeler e.d.

18 Beroepssporter, trainer, sportleraar

19 Sociale hulpverleners, vertalers e.d.

$\begin{array}{rrrrr}34.000 & 38.000 & 39.000 & -1.000 & 0,0012 \\ 178.000 & 205.000 & 240.000 & -35.000 & 0,0207 \\ 17.000 & 19.000 & 14.000 & 5.000 & 0,1374 \\ 29.000 & 28.000 & 37.000 & -9.000 & 0,0517 \\ 267.000 & 323.000 & 385.000 & -62.000 & 0,0265 \\ 51.000 & 96.000 & 122.000 & -26.000 & 0,0459 \\ 15.000 & 17.000 & 24.000 & -7.000 & 0,0865 \\ 12.000 & 15.000 & 28.000 & -13.000 & 0,2214 \\ 18.000 & 20.000 & 32.000 & -12.000 & 0,1387 \\ 275.000 & 305.000 & 335.000 & -30.000 & 0,0080 \\ 10.000 & 11.000 & 11.000 & 0 & 0,0042 \\ 20.000 & 20.000 & 39.000 & -19.000 & 0,2319 \\ 29.000 & 30.000 & 51.000 & -21.000 & 0,1721 \\ 17.000 & 18.000 & 20.000 & -2.000 & 0,0169 \\ 10.000 & 12.000 & 16.000 & -4.000 & 0,0480 \\ 108.000 & 114.000 & 168.000 & -54.000 & 0,1035\end{array}$

18. Bij een aantal beroepen komt de realisatie in 1992 beneden de door het CBS gehanteerde benedengrens van 5.000 personen, en is daarom niet in de tabel opgenomen. Voor zover de realisaties groter zijn dan 2.500 zijn ze echter wel meegenomen in de evaluatie. De aantallen beneden 2.500 konden ook voor de evaluatie niet worden gebruikt. Voor het totaal beeld zijn deze kleine beroepen echter niet belangrijk. 
$-61-$

Tabel 4.7. Voorspelfouten per beroepsklasse (vervolg)

CBS-beroepsklasse 1985 prognose 1992 realisatie 1992

voorspelfout verlies

20 Hogere leid. functies bij openb. bestuur

21 Beleidvoerende en hogere leid. functies

30 Leidinggevend administratief personeel

31 Uitvoerend hoofdambtenaar

32 Secretaresse, typist, datatypist e.d.

33 Bankemployé, lokettisten e.d.

34 Computerapparatuur-operateurs e.d.

35 Leidinggevend personeel transportbedrijf

37 Postsorteerder, postbesteller e.d.

38 Telefonist, telegrafist

39 Diverse administratieve functies

40 Directeur en bedrijfsleider groothandel

41 Directeur en bedrijfsleider detailhandel

42 Zelfst. groothandelaar, tussenhandelaar

43 Zelfstandige winkelier

45 Verkoopchef, filiaalhouder, inkoper e.d.

46 Vertegenwoordiger

47 Verzekeringsagenten, makelaars e.d.

48 Winkelbediende, marktverkoper e.d.

50 Directeur/bedrijfsleider horecabedrijf

51 Zelfstandig hotel-, rest-, caféhouder

52 Leidinggevend huishoudelijk personeel

53 Kok, kelner, buffetbediende e.d.

54 Huishoudelijk- en verzorgend personeel

55 Huisbewaarders en schoonmaakpersoneel

56 Wasser, perser

57 Kapper, schoonheidsspecialist

58 Brandweer-, politiepersoneel, bewakers

59 Diverse commerciele functies

60 Bedrijfsleider land- en tuinbouw

61 Zelfstandige land- en tuinbouwers

62 Agrarische arbeiders

64 Visser, jager

70 Leidinggevend produktiepersoneel

72 Hoogovenarbeiders, walsers, gieters e.d.

73 Houtzager, papiermaker

74 Chemische procesarbeiders

75 Spinners, wevers e.d.

77 Voedingsmiddelen, drankbereider

79 Kleermakers, stoffeerders e.d.

80 Schoenmaker, ledermaker

81 Meubelmaker en andere houtbewerkers

83 Smeden, gereedschapsmakers e.d.

84 Instrumentmakers, monteurs e.d.

85 Electromonteurs, -reparateurs

87 Loodgieter, pijpfitter, lasser e.d.

89 Glas-, aardewerkvormer e.d. functies

90 Rubber-, plasticproduktenmaker

91 Papierwaren-, kartonnagewerker

\begin{tabular}{|c|c|c|c|c|}
\hline 4.000 & 5.000 & 6.000 & -1.000 & 0,0648 \\
\hline 163.000 & 192.000 & 272.000 & -80.000 & 0,0859 \\
\hline 17.000 & 21.000 & 32.000 & -11.000 & 0,1147 \\
\hline 16.000 & 17.000 & 23.000 & -6.000 & 0,0542 \\
\hline 147.000 & 184.000 & 149.000 & 35.000 & 0,0550 \\
\hline 291.000 & 315.000 & 397.000 & -82.000 & 0,0429 \\
\hline 11.000 & 14.000 & 8.000 & 6.000 & 0,7445 \\
\hline 27.000 & 29.000 & 20.000 & 9.000 & 0,1664 \\
\hline 44.000 & 47.000 & 49.000 & -2.000 & 0,0022 \\
\hline 18.000 & 17.000 & 12.000 & 5.000 & 0,1524 \\
\hline 379.000 & 454.000 & 456.000 & -2.000 & 0,0000 \\
\hline 30.000 & 35.000 & 42.000 & -7.000 & 0,0274 \\
\hline 17.000 & 19.000 & 22.000 & -3.000 & 0,0167 \\
\hline 22.000 & 26.000 & 30.000 & -4.000 & 0,0153 \\
\hline 82.000 & 93.000 & 39.000 & 54. & 1,9630 \\
\hline 45.000 & 49.000 & 53.000 & -4.000 & 0,0053 \\
\hline 50.000 & 53.000 & 50.000 & 3.000 & 0,0049 \\
\hline 35.000 & 42.000 & 56.000 & -14.000 & 0,0589 \\
\hline 232.000 & 290.000 & 440.000 & -150.000 & 0,1164 \\
\hline 13.000 & 16.000 & 28.000 & -12.000 & 0,1624 \\
\hline 30.000 & 34.000 & 20.000 & 14.000 & 0,5189 \\
\hline 10.000 & 10.000 & 9.000 & 1.000 & 0,0112 \\
\hline 108.000 & 128.000 & 183.000 & -55.000 & 0,0885 \\
\hline 181.000 & 195.000 & 254.000 & -59.000 & 543 \\
\hline 137.000 & 189.000 & 165.000 & 24.000 & 0,0223 \\
\hline 10.000 & 10.000 & 8.000 & 2.000 & 0,0299 \\
\hline 31.000 & 31.000 & 41.000 & -10.000 & 0,0620 \\
\hline 56.000 & 61.000 & 68.000 & -7.000 & 0,0104 \\
\hline 29.000 & 35.000 & 36.000 & -1.000 & 0,0028 \\
\hline 6.000 & 6.000 & 7.000 & -1 & 1,0018 \\
\hline 129.000 & 134.000 & 105.000 & 29.000 & 0,0818 \\
\hline 131.000 & 131.000 & 156.000 & -25.000 & 0,0271 \\
\hline 4.000 & 4.000 & 5.000 & -1.000 & 0,0607 \\
\hline 101.000 & 95.000 & 252.000 & -157.000 & 0,3912 \\
\hline 13.000 & 14.000 & 14.000 & 0 & 0,0043 \\
\hline 7.000 & 5.000 & 6.000 & -1.000 & 0,0212 \\
\hline 24.000 & 28.000 & 29.000 & -1.000 & 0,0009 \\
\hline 12.000 & 11.000 & 9.000 & 2.000 & 0,0498 \\
\hline 60.000 & 62.000 & 69.000 & -7.000 & 0,0109 \\
\hline 32.000 & 36.000 & 36.000 & 0 & 0,0000 \\
\hline 8.000 & 8.000 & 7.000 & 1.000 & 0,0119 \\
\hline 18.000 & 18.000 & 24.000 & -6.000 & 0,0729 \\
\hline 41.000 & 33.000 & 54.000 & -21.000 & 0,1544 \\
\hline 155.000 & 143.000 & 167.000 & -24.000 & 0,0208 \\
\hline 110.000 & 136.000 & 120.000 & 16.000 & 0,0192 \\
\hline 105.000 & 112.000 & 117.000 & -5.000 & 0,0016 \\
\hline 9.000 & 9.000 & 7.000 & 2.000 & 0,1507 \\
\hline 14.000 & 14.000 & 16.000 & -2.000 & 0,0285 \\
\hline 6.000 & 6.000 & 5.000 & 1.000 & 0,0214 \\
\hline
\end{tabular}


Tabel 4.7. Voorspelfouten per beroepsklasse (vervolg)

\begin{tabular}{|c|c|c|c|c|c|}
\hline CBS-beroepsklasse & $\begin{array}{r}\text { aantal } \\
1985\end{array}$ & $\begin{array}{c}\text { prognose } \\
1992\end{array}$ & $\begin{array}{c}\text { realisatie } \\
1992\end{array}$ & voorspelfout & verlies \\
\hline 92 Drukker en verwante functies & 43.000 & 49.000 & 56.000 & -7.000 & 0,0154 \\
\hline 93 Schilder e.d. & 39.000 & 39.000 & 46.000 & -7.000 & 0,0245 \\
\hline 94 Ambachts- en industrieberoepen n.e.g. & 13.000 & 12.000 & 18.000 & -6.000 & 0,0990 \\
\hline 95 Metselaar, timmerman, e.a. bouwvakkers & 169.000 & 174.000 & 189.000 & -15.000 & 0,0065 \\
\hline 96 Machinisten e.a. bedieners van machines & 6.000 & 4.000 & 5.000 & -1.000 & 0,0383 \\
\hline 97 Laders, lossers, inpakkers e.d. & 160.000 & 172.000 & 174.000 & -2.000 & 0,0001 \\
\hline 98 Chauffeurs, matrozen, treinbestuurders & 148.000 & 160.000 & 205.000 & -45.000 & 0,0491 \\
\hline 99 Sjouwers, dokwerkers e.d. & 45.000 & 46.000 & 37.000 & 9.000 & 0,0712 \\
\hline
\end{tabular}

De prognoses per beroepsklasse bevatten een aantal uitschieters. Voor de zelfstandige winkeliers (beroepsklasse 43 ) werd een groei van $14 \%$ voorspeld terwijl de werkgelegenheid met $53 \%$ kromp. Bij computerappartuur-operateurs e.d. (beroepsklasse 34 ) werd $23 \%$ groei verwacht, terwijl de werkgelegenheid daalde met $34 \%$. Bij de zelfstandige hotel- restaurant en caféhouders (beroepsklasse 51 ) werd een groei van $12 \%$ verwacht terwijl het aantal banen met $35 \%$ daalde. Juist bij al deze sterke veranderingen doet zich uiteraard de vraag voor in hoeverre zij inderdaad zijn toe te schrijven aan echte werkgelegenheidsveranderingen, of dat er sprake is van drastische wijzigingen in de wijze van meten of classificeren.

\section{De voorspelkwaliteit}

Tabel 4.8 bevat de gegevens over de totale voorspelkwaliteit van de uitbreidingsvraagprognoses naar beroepsklasse. Bij een beschouwing van de absolute omvang van de voorspellingen blijkt de prognose $73 \%$ van de voorspelfout van $S A B$ te bevatten. Deze verbetering is aanmerkelijk lager dan het prognoseresultaat van de bedrijfssectorprognoses. Een vergelijking met tabel 4.6 waarin de bedrijfssectorprognoses met behulp van de vaste-coëfficiëntenmatrix naar beroepsklassen werden omgezet, laat zien dat de beroepsklasseprognoses niet beter zijn dan ze zouden zijn geweest als deze vaste-coëfficiëntenmethode zou zijn gehanteerd voor de verbijzondering van de sectorprognoses van het $\mathrm{CPB}^{19}$. Uit de vergelijking met deze tabel blijkt dat, bij gegeven kwaliteit van de bedrijfssectorprognoses, ongeveer de helft van de voorspelfout van de prognoses van de uitbreidingsvraag per beroepsklasse voortkomt uit fouten in de prognose van de beroepenstructuur. Het gemiddeld verlies $(0,0738)$ zou immers teruglopen tot 0,0358 als op basis van de bedrijfssectorprognoses, met behulp van de juiste beroepenstructuur, beroepsklasseprognoses zouden zijn gemaakt. De bedrijfssectorprognoses zijn overigens gebaseerd op meer recente

19. Het verlies bij SAB op beroepsklasseniveau, zou in principe gelijk moeten zijn aan het verlies bij de vastecoëfficiëntenmethode met de bedrijfssectoraantallen van 1985 en de structuurmatrix van 1985 in tabel 4.6. Het kleine verschil wordt veroorzaakt doordat de tweede methode gebruik maakt van de volle matrix bedrijfssector $x$ beroepsklasse waarin een groter aantal personen in een restcategorie terecht komen omdat of de beroepsklasse, of de bedrijfssector niet bekend is. 
informatie (tot en met 1988), terwijl de prognose van de beroepenstructuur gebaseerd is op gegevens van 1985 en eerder. Bij gelijkwaardigheid van de gehanteerde informatie zal deze verhouding dus waarschijnlijk lager uitvallen.

Door te kijken naar de relatieve prognoses wordt het verschil tussen de werkgelegenheidsprognoses per beroepsklasse en de SAB-prognose nog kleiner. Het gemiddeld verlies van de prognoses is nu zelfs $95 \%$ van SAB.

Tabel 4.8. Totaal-overzicht voorspelkwaliteit prognoses uitbreidingsvraag per beroepsklasse

\begin{tabular}{llccc} 
Methode & gem. verlies prognose & gem. verlies SAB & score & $\begin{array}{l}\text { aantal } \\
\text { beroepsklassen }\end{array}$ \\
\hline Absoluut & 0,0738 & 0,1006 & 0,73 & 75 \\
Relatief & 0,0727 & 0,0767 & 0,95 & 75 \\
Altijd trend & 0,0290 & 0,0617 & 0,47 & 11 \\
Soms trend & 0,0151 & 0,0217 & 0,69 & 7 \\
Nooit trend & 0,1096 & 0,1020 & 1,07 & 57 \\
\hline
\end{tabular}

In paragraaf 2.4 werden als mogelijk zwakke punten van de gehanteerde methodiek genoemd de aannames met betrekking tot de vraagbepaaldheid van de ontwikkeling van de werkgelegenheid op beroepsklasseniveau, het veelvuldig niet gebruiken van trendextrapolaties en het verloren laten gaan van de informatie die met name in de laatste waarneming ligt besloten. De juistheid van de aannames met betrekking tot de vraagbepaaldheid van de werkgelegenheid zijn moeilijk binnen het kader van deze evaluatie te bepalen. In tabel 4.8 zijn de voorspelkwaliteiten uitgesplitst naar de wijze waarop de trend in het model werd opgenomen. Omdat voor aan de ene kant de agrarische en industriële sectoren en aan de andere kant voor de tertiaire en kwartaire sectoren aparte vergelijkingen zijn geschat, kan de trendterm altijd, de ene keer wel en de andere keer niet, en nooit zijn opgenomen ${ }^{20}$. De afzonderlijke voorspelfouten voor deze drie groepen zijn alleen op de relatieve wijze berekend, zodat fouten in de werkgelegenheidsprognoses als zodanig geen invloed op deze cijfers hebben.

De tabel laat zien dat het opnemen van een trend in de prognosesmethodiek inderdaad belangrijk is. De beroepsklassen waarbij altijd een trend is geëxtrapoleerd, vertonen de beste score, terwijl de categorie zonder enige trendextrapolatie het slechtst scoort. Het gemiddeld verlies van de categorie met in een van beide gevallen een trend is kleiner dan de categorie met in beide gevallen een trend. Overigens geven deze beroepsklassen ook een betere voorspelling op basis van de Same As Before prognose. Het is opmerkelijk dat deze categorie vooral beroepen betreft waarin relatief

20. Sommige beroepen komen slechts in een van de twee groepen voor. Als hier wel een trend bij is opgenomen, dan vallen ze dus onder altijd en als hier geen trend is opgenomen dan vallen ze dus onder nooit. 
weinig verandering optreedt. Juist de beroepsklassen waarbij geen trendextrapolatie is gehanteerd, kennen de grootste veranderlijkheid. Waarschijnlijk is door deze veranderlijkheid de trendterm destijds niet significant geweest. Statistische significantie en economische relevantie gaan kennelijk niet altijd samen.

Het niet opnemen van de trendvariabele verklaart dan ook voor een groot deel de matige voorspelresultaten van de werkgelegenheidsprognoses per beroepsklasse. De beroepsklassen waarbij een trend is opgenomen hebben een voorspelkwaliteit die vergelijkbaar is met de voorspelkwaliteit van de bedrijfssectorprognoses. De beroepsklassen waarbij geen trend is opgenomen hebben zelfs een slechtere voorspelkwaliteit dan de Same As Before prognose. Dit kan er op wijzen dat het inderdaad, zoals in paragraaf 2.4 reeds werd verondersteld, een tekortkoming van de aanpak was dat de prognoses niet werden afgestemd op de laatste waarnemingen, om zo de onverklaarde effecten in ieder geval tot en met dit basis jaar in de prognoses verwerkt te hebben.

Op grond van tabel 4.8 kan dan ook geconcludeerd worden dat door het opnemen van een trendterm er duidelijk mogelijkheden zijn de kwaliteit van de werkgelegenheidsprognoses per beroepsklasse aanmerkelijk te verbeteren. Wel dient men zich hierbij te realiseren dat de beroepsklassen waarbij altijd een trend is gebruikt waarschijnlijk die beroepsklassen zijn waarbij de trend het beste meetbaar (dat wil zeggen significant) was. Indien ook bij de andere beroepsklassen een trendterm zou worden gehanteerd zal de voorspellende waarde hiervan daarom waarschijnlijk lager zijn dan bij de gevallen waar nu reeds een trend is opgenomen. Door de introductie van random-coefficients-modellen, zoals bij de prognoses van 1993 gebeurde, is het naar verwachting echter mogelijk om ook de minder duidelijke trends op een verantwoorde wijze te extrapoleren. Hierbij zal de trend-extrapolatie voorzichtiger worden naarmate de trend minder significant is in de historische periode. Er hoeft dan niet, zoals bij de hier geëvalueerde prognoses een alles-of-nietskeuze gemaakt te worden tussen wel of geen trend opnemen.

\section{Een verklaring van de voorspelfout}

Tabel 4.9 geeft een verklaring van de standaarddeviatie van de voorspelfouten van de werkgelegenheidsprognoses per beroepsklasse. In de verklaring is allereerst weer een schaaleffect opgenomen, dat aangeeft in hoeverre de voorspelfout gerelateerd is aan de omvang van een beroepsklasse. Dit schaaleffect ligt weer beneden de waarde 1 , overeenkomstig de bevindingen in de vorige paragraaf. Dit betekent dat de voorspelfout minder dan proportioneel toeneemt met de omvang van de beroepsklasse. Grote beroepsklassen hebben relatief gezien dus betrouwbaardere prognoses dan kleinere beroepsklassen.

Verder bevat de verklaring van de standaarddeviatie de wijze van trend-extrapolatie als verklarende variabele. De twee groepen beroepsklassen waarin altijd of soms een trend is geëxtrapoleerd blijken overeenkomstig de eerdere bevindingen significant betere resultaten te hebben dan de groep zonder trendextrapolatie. 
Ten slotte is een verband gelegd tussen de risico-indicatoren en de omvang van de voorspelfout. Verwacht mag worden dat de in de algehele typering van de werkgelegenheidsperspectieven van een beroepsklasse opgenomen risico-indicatoren een indicatie geven van de kans dat de werkelijke werkgelegenheidsontwikkeling afwijkt van de prognose. Bij de spreidingsindicator zou er bij een grotere spreiding een geringere kans zijn dat de feitelijke ontwikkeling (abrupt) afwijkt van de prognose. Dit effect wordt ook teruggevonden in de schattingsresultaten. Bij de conjuctuurindicator zou een grotere conjunctuurgevoeligheid echter een groter risico met zich mee moeten brengen terwijl het omgekeerde effect wordt gevonden. Wellicht wordt dit veroorzaakt door het feit dat op bedrijfssectorniveau de prognoses van de industriële sectoren beter zijn, terwijl juist bij de beroepen die in deze sectoren veel voorkomen de grootste conjunctuurgevoeligheid zal optreden. Beide effecten, zowel van de spreidingsindicator als van de conjunctuurgevoeligheid, zijn overigens niet significant.

Tabel 4.9. Een verklaring van de standaarddeviatie van de voorspelfouten van de prognoses van de uitbreidingsvraag per beroepsklasse.

\begin{tabular}{lcc} 
Variabele & parameter & t-waarde \\
\hline Schaal & & 11,50 \\
Constante & 0,84 & 1,31 \\
Altijd trend & 1,03 & 2,65 \\
Soms trend & $-0,57$ & 3,40 \\
Spreidingsindicator & $-0,83$ & 0,66 \\
Conjunctuurindicator & $-0,01$ & 0,48
\end{tabular}

Tabel 4.10. De overschatting van veranderingen bij de relatieve uitbreidingsvraag per beroepsklasse.

onderschattingscoëfficiënt t-waarde

$\begin{array}{lrr}\text { Totaal } & -0,33 & 1,18 \\ \text { Altijd trend } & 0,31 & 0,37 \\ \text { Soms trend } & -0,59 & 0,10 \\ \text { Nooit trend } & -0,85 & 2,08\end{array}$

\section{Overschatting van verandering}

Tabel 4.10 toont de mate waarin bij de werkgelegenheidsprognoses per beroepsklasse sprake was van een over- of onderschatting van veranderingen. Het gaat hierbij wederom om de relatieve voorspelfouten. Voor de voorspelfout met betrekking tot de totale werkgelegenheidsontwikkeling is dus gecorrigeerd. Alleen bij de beroepsklassen waarbij geen trend werd gebruikt is er sprake van 
significante overschatting van veranderingen. Kennelijk zijn de voorspelde veranderingen weinig informatief geweest en bevatten zij hoofdzakelijk ruis. Deze ruis is waarschijnlijk ontstaan bij de beroepsklassen waarbij geen trend is gehanteerd, door meetfouten, maar vooral door het ten onrechte negeren van het verschil tussen de laatste waarneming en de regressielijn.

\section{Kwalitatieve typeringen}

De evaluatie van de werkgelegenheidsprognoses tot nog toe is gebaseerd op de puntvoorspellingen zoals die vermeld zijn in de rapportage (De Grip e.a., 1989). Zoals gezegd, krijgen leerlingen echter niet deze puntschattingen gepresenteerd, maar zijn er kwalitatieve typeringen gemaakt van de prognoses. Er is een vijfdeling gemaakt op basis van de volgende indeling:

\begin{tabular}{|c|c|c|c|c|c|}
\hline & & EBK & $\leq$ & $-1 \%$ & erg laag \\
\hline$-1 \%$ & $<$ & EBK & $\leq$ & $9 \%$ & laag \\
\hline $9 \%$ & $<$ & EBK & $\leq$ & $15 \%$ & gemiddeld \\
\hline $15 \%$ & $<$ & EBK & $\leq$ & $25 \%$ & hoog \\
\hline $25 \%$ & $<$ & EBK & & & erg hoog \\
\hline
\end{tabular}

waarbij EBK staat voor uitbreidingsvraag in een beroepsklasse (De Grip e.a., 1989, blz. 10).

Tabel 4.11 is een kruistabel van de prognose en de realisatie van deze kwalitatieve typering. Hierbij is weer gebruik gemaakt van de relatieve prognoses. Het resultaat bij de absolute prognoses wordt volledig gedomineerd door de onderschatting (of onjuiste meting) van de totale werkgelegenheidsgroei. Van de 75 beroepsklassen waarvan een realisatie bekend is, hebben er in absolute termen 13 de juiste kwalitatieve typering. Door de onderschatting zijn er echter slechts 13 beroepsklassen waarbij de prognose hoger is dan de realisatie, terwijl bij 49 beroepsklassen de realisatie hoger is dan de prognose.

Tabel 4.11. Typeringen van de werkgelegenheidsontwikkeling per beroep en de realisaties (relatief)

\begin{tabular}{lcccccr}
\hline Realisatie & erg laag & laag & $\begin{array}{l}\text { prognose } \\
\text { gemiddeld }\end{array}$ & hoog & erg hoog & totaal \\
\hline Erg laag & 9 & 12 & 6 & 3 & 0 & 30 \\
Laag & 3 & 3 & 4 & 2 & 1 & 13 \\
Gemiddeld & 2 & 0 & 2 & 0 & 0 & 4 \\
Hoog & 1 & 7 & 2 & 2 & 0 & 12 \\
Erg hoog & 1 & 5 & 1 & 7 & 2 & 16 \\
Totaal & 16 & 27 & 15 & 14 & 3 & 75 \\
\hline
\end{tabular}

Mede gezien de metingsverschillen tussen de AKT en de EBB geven de relatieve prognoses een genuanceerder beeld van de trefzekerheid van de kwalitatieve typeringen. Op de diagonaal van de matrix 4.11 bevinden zich 18 van de 75 beroepsklassen. Dat betekent dat $24 \%$ van de beroepsklassen de juiste typering heeft gekregen. Als daaraan de beroepsklassen worden 
toegevoegd waar de kwalitatieve typering slechts één categorie naast de voorspelde typering ligt, dan groeit dit percentage naar $61 \%$ (46 gevallen). In de tabel is goed te herkennen dat het weglaten van de trendvariabele ook de kwalitatieve typeringen sterk heeft beïnvloed. Deze tekortkoming leidt ertoe dat de realisaties gemiddeld in een extremere categorie terecht komen dan de prognoses. Dit is aangegeven met de vetgedrukte matrixelementen. Deze onderschattingscurve bevat $45(60 \%)$ van de beroepsklassen.

Dit betekent dat er weliswaar vrij veel typeringen niet geheel correct blijken te zijn, maar dat doorgaans slechts te weinig of geen verandering is voorspeld. In 20 van de 75 gevallen is er echter sprake van een typering in de verkeerde richting. Daarbij gaat het in 14 gevallen om een verwachte (zeer) lage groei van beroepsklassen waarbij zich uiteindelijk een (zeer) hoge werkgelegenheidsgroei heeft voorgedaan. Bijlage I geeft een overzicht van de gemaakte typering en de realisatie hiervan per beroep. De meest extreme misser betreft het leidinggevend produktiepersoneel (beroepsklasse 70) waarbij aan de verwachte werkgelegenheidsgroei de typering 'zeer laag' werd gegeven, maar 'zeer hoog' achteraf de juiste typering blijkt te zijn geweest. Ook bij juristen, notarissen en rechters (beroepsklasse 12), journalisten, auteurs en redacteuren (beroepsklasse 15) kunstenaars, ontwerpers, fotografen en filmers (beroepsklasse 16), sociale hulpverleners, vertalers (beroepsklasse 19), hogere leidinggevende functies bij het openbaar bestuur (beroepsklasse 20), uitvoerend hoofdambtenaren (beroepsklasse 31), bankemployees en lokettisten (beroepsklasse 33), chauffeurs, matrozen en treinbestuurders (beroepsklasse 98), vissers en jagers (beroepsklasse 64), meubelmakers en andere houtbewerkers (beroepsklasse 81 ) en ambachts- en industrieberoepen n.e.g. (beroepsklasse 94) werd de werkgelegenheidsontwikkeling als laag of zeer laag getypeerd terwijl de groei in de werkgelegenheid in werkelijkheid hoog of zeer hoog blijkt te zijn geweest. Relatief veel van deze beroepen zijn sterk vertegenwoordigd in de kwartaire sector en bij de overheid, waar de sectorale prognoses van het CPB ook te laag waren uitgevallen. Bovendien komen er in verschillende van deze beroepsklassen veel kleinere banen voor.

Bij secretaresses, (data-)typisten (beroepsklasse 32), computerapparatuur-operators e.d. (beroepsklasse 34), diverse commerciele functies (beroepsklasse 59) en electromonteurs, -reparateurs (beroepsklasse 85 ) werd juist een hoge of zeer hoge werkgelegenheidsgroei verwacht maar blijkt de groei in werkelijkheid juist laag of zeer laag te zijn geweest.

Van deze gevallen met een typering in de verkeerde richting is er slechts én beroepsklasse (computerapparatuur-operators e.d., beroepsklasse 34) die ook genoemd werd bij de beroepsklassen met de grootste voorspelfouten op basis van de puntschattingen. De overige beroepsklassen met de grootste voorspelfouten zijn allemaal gevallen waarbij de feitelijk opgetreden werkgelegenheidsontwikkeling onvoldoende werd aangegeven. De werkgelegenheidsgroei in deze beroepsklassen is getypeerd als gemiddeld, terwijl er uiteindelijk sprake blijkt te zijn geweest van een zeer lage of zeer hoge groei. Dit illustreert nogmaals dat het achterwege laten van de trendterm verreweg de grootste component van de prognoseproblemen heeft veroorzaakt.

Vanwege deze grote voorspelfout als gevolg van het negeren van de trend is de waargenomen standaarddeviatie van de voorspelfout zeer groot. Bijlage I bevat deze cijfers, berekend op basis van 
de schattingen in tabel 4.9. Op grond van deze standaarddeviatie kan de kans worden berekend dat de realisatie dezelfde typering krijgt als de prognose. Zoals beschreven in paragraaf 2.10 is deze kans bij de gehanteerde wijze van typeren doorgaans kleiner dan bij intervallen die symmetrisch zijn rondom de prognose. Alleen bij de beroepsklassen die getypeerd zijn als 'erg laag' of 'erg hoog' is de kans op juiste typering veel groter, doordat deze typeringsintervallen aan een kant onbegrensd zijn. De vijfde kolom van de tabel in bijlage I geeft aan hoe groot de kans op een juiste typering zou zijn geweest als de gehanteerde intervallen symmetrisch rondom de puntprognose hadden gelegen. Hierbij is een intervallengte gekozen die gelijk is aan de feitelijk gehanteerde intervallen. De kans dat de realisatie en de prognose dezelfde typering krijgen is niet erg hoog. Hij varieert tussen 0,05 en 0,36 en het gewogen gemiddelde is $19 \%$ (zie tabel 4.12). Bij de werkelijk gehanteerde intervallen staan de grenzen echter vast en hoeft het interval niet per se symmetrisch rondom de voorspelling te liggen. In principe verkleint hierdoor de kans dat de typering juist is. De zesde kolom van de tabel in bijlage I geeft daarom aan hoe groot de kans is op een juiste typering als de prognose op een willekeurige plaats in het betreffende interval ligt. Hierbij is de voorspelfout als gegeven genomen. De gemiddelde kans dat prognose en realisatie in hetzelfde interval terecht komen daalt inderdaad (meer dan) $1 \%$ tot $18 \%$. Voor een groot aantal beroepsklassen is de kans op een juiste typering 0 . Dit betekent dat bij de betreffende beroepsklasse de voorspelfout dermate groot is dat prognose en realisatie onmogelijk in één interval kunnen liggen bij de laatstgenoemde aanpak. Bij de berekening is echter nog steeds de lengte van de hoekintervallen gelijkgesteld met de lengte van de buurintervallen. Feitelijk zijn de hoekintervallen echter aan een kant onbegrensd. Hierdoor is de feitelijke kans op een juiste typering voor deze gevallen veel hoger (zevende kolom van de tabel in bijlage I). Gemiddeld is de trefkans nu 25\%. Dit komt redelijk overeen met het feitelijke resultaat van $24 \%$ juiste typeringen. Dit verschil komt louter voort uit het toeval.

Tabel 4.12. De gemiddelde trefkans bij verschillende soorten intervallen voor de typering van de uitbreidingsvraag per beroepsklasse

Intervalkeuze

gemiddelde trefkans

$\%$

Symmetrisch

19

Willekeurige positie binnen begrensd interval 18

Feitelijk gehanteerd interval 25

Resultaat

24

Figuur 4.3 geeft het verband tussen de standaarddeviatie van een prognose en de kans op een juiste typering zowel bij een symmetrisch interval als bij het toentertijd vastgestelde interval. De figuur laat nogmaals het verschil zien tussen de trefkans bij symmetrische intervallen en de vastliggende intervallen die gebruikt zijn bij de typeringen van het informatiesysteem. Bij de symmetrische intervallen valt het verschil op tussen het 'gemiddelde'-interval (lengte 6\%) en de overige intervallen (lengte 10\%). De symmetrische intervallen hebben in principe een grotere kans op een juiste typering. Het verschil met de niet-symmetrische intervallen is hier echter klein 
vanwege de zeer grote standaarddeviatie van de voorspelfouten. De verdeling is zo vlak dat het niet erg veel uitmaakt of het interval precies symmetrisch is. In de gevallen van de extreme typeringen ('zeer hoog' en 'zeer laag') scoort de feitelijk gehanteerde typering echter veel beter doordat deze grensintervallen aan één kant onbegrensd zijn.

Figuur 4.3. Kans op een juiste kwalitatieve typering bij symmetrische en werkelijke intervallen bij de uitbreidingsvraag per beroep

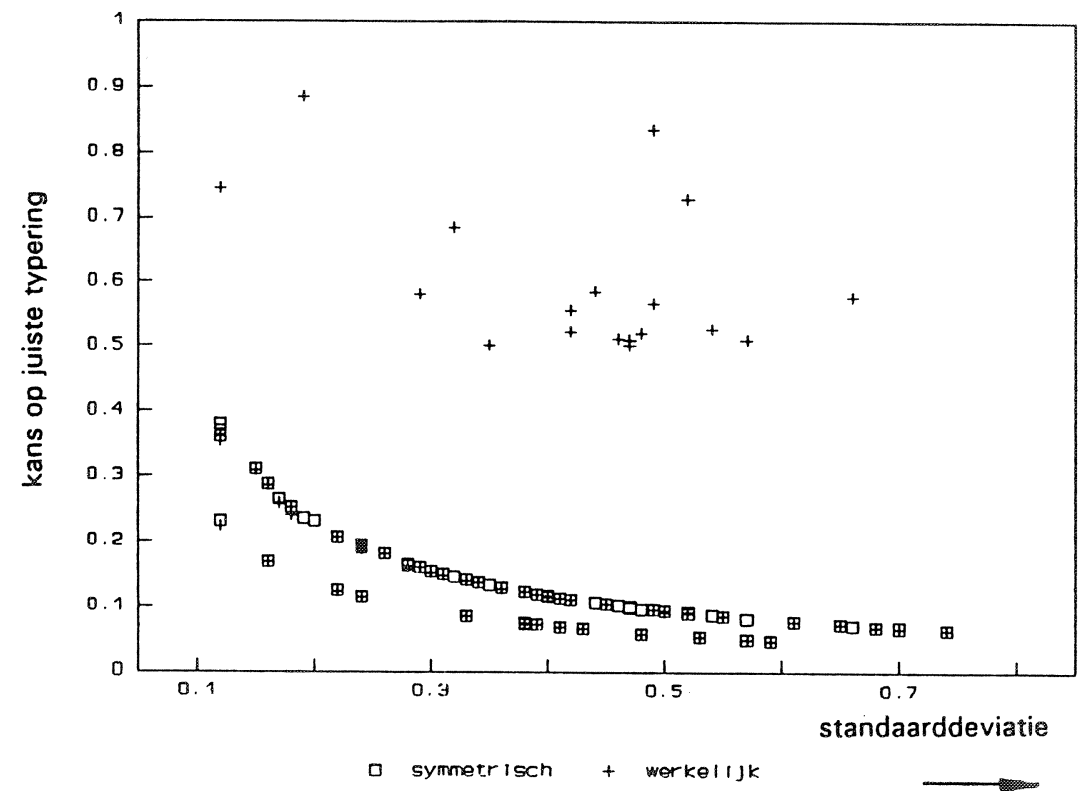

\section{Conclusies}

Concluderend kan worden gesteld dat de grootste tekortkoming van de werkgelegenheidsprognoses per beroepsklasse is, dat in veel gevallen geen extrapolatie heeft plaatsgevonden van de trendmatige ontwikkelingen van de beroepenstructuur. Daarnaast dient de informatieve waarde van de laatste waarneming niet onderschat te worden. Door een modelspecificatie te kiezen waarbij de laatste waarneming dient als basis voor de voorspelde veranderingen, kan informatie die niet in het model zit, maar die wel reeds aanwezig is in deze laatste observatie verwerkt worden in de prognoses. In de methodiek die inmiddels wordt gehanteerd, wordt aan beide punten reeds tegemoet gekomen.

Bij de typeringen is de trefzekerheid als gevolg van bovengenoemde problemen klein geweest. De meeste en de grootste voorspelfouten betreffen echter de bij de prognoses genegeerde veranderingen in de omvang van de werkgelegenheid. Prognoses en realisaties die in een tegengestelde richting uitvielen komen minder vaak voor. De lage trefkans roept de vraag op of de intervallen op basis van de gehanteerde schaal niet te klein zijn. Uiteraard zal een verbeterde prognosemethodiek de trefkans vergroten, maar onder de aanname dat het mogelijk is ongeveer de helft van de voorspelfout weg te halen (vergelijkbaar met de voorspelkwaliteit van de 
beroepsklassen waarbij altijd een trend is gebruikt), zou de trefkans nog niet hoger zijn dan $45 \%$. Om aan deze onzekerheid uitdrukking te geven is het wellicht beter de werkgelegenheidsprognoses van beroepsklassen te typeren met een dubbele typering, bijvoorbeeld 'hoog tot erg hoog', of 'gemiddeld tot laag'. Hierdoor zou de trefkans boven de $70 \%$ kunnen uitkomen en is het mogelijk enigszins de symmetrie van het interval te behouden.

De beroepsklassenindeling van het CBS is inmiddels voor de prognose-doeleinden vervangen door de ROA-classificatie. Doordat deze classificatie beter geschikt is voor de problematiek aansluiting onderwijs-arbeidsmarkt en doordat de prognoses thans in stappen plaatsvinden (eerst beroepssegmenten, vervolgens op basis daarvan beroepsklassen) wordt waarschijnlijk het prognoseresultaat ook verbeterd. Het is binnen het kader van deze evaluatie echter onmogelijk hierop zicht te krijgen.

\subsection{Vervangingsvraag per beroep}

De tweede component die samen met de uitbreidingsvraag de baanopeningen per beroepsklasse bepaalt is de vervangingsvraag. Zoals al werd opgemerkt in paragraaf 2.5 werd bij de toentertijd opgestelde prognoses in feite niet de vervangingsvraag, maar de uitstroom uit de beroepsklasse voorspeld. Bij de uitstroom worden alle banen gerekend die vrijkomen door het vertrek van een werkende naar een andere beroepsklasse of buiten de werkzame beroepsbevolking. Daarbij zitten dus ook de banen die niet opnieuw vervuld worden. Bij de vervangingsvraag worden de niet opnieuw vervulde banen niet meegerekend.

Om te kunnen komen tot een evaluatie van de prognoses moet eerst de feitelijke uitstroom of de vervangingsvraag voor de prognoseperiode bepaald worden. Hierbij doen zich echter dezelfde meetproblemen voor als bij het opstellen van prognoses. Bij deze evaluatie worden daarom net als bij de prognose uitstroomcijfers gehanteerd die bepaald zijn volgens de netto-methode. Het gelijktijdig voorkomen van in- en uitstroom binnen één afzonderlijk onderscheiden groep is daarom niet waargenomen. Door de vele kleine aantallen is er bovendien mogelijk sprake van aanzienlijke meetfouten in de cijfers. Dit betekent dus dat de fouten als gevolg van het hanteren van de nettomethode niet getoetst kunnen worden en dat het evaluatieresultaat beïnvloed zal zijn door de mindere kwaliteit van de metingen van de gerealiseerde uitstroom. Verder bleek het, vanwege de veranderingen bij de EBB, niet mogelijk uitstroomcijfers te verkrijgen op basis van de 1-urenondergrens. In deze paragraaf worden daarom uitstroom-cijfers op basis van de 12-uren-grens vergeleken met de prognoses voor de 1-uren-grens. Bij de nieuwste prognoses in het kader van het informatiesysteem (Dekker e.a., 1993) is gebleken dat de waargenomen vervangingsvraag bij de 12-uren-grens doorgaans hoger is dan de destijds gehanteerde vervangingsvraag. Dit wordt waarschijnlijk veroorzaakt doordat een groot deel van de kleine banen bezet worden door jongeren. Het bruto-verloop bij deze banen is weliswaar groot, maar het wordt niet waargenomen omdat in deze leeftijdsgroepen de instroom groter is dan de uitstroom. Doordat dit effect niet bij alle beroepsklassen in gelijke mate voorkomt, zal dit de evaluatieresultaten enigszins vertekenen.

Tabel 4.13 geeft een overzicht van de prognoses per beroepsklasse, de realisaties, de voorspelfout en het verlies. Als referentieprognose wordt, zoals beschreven in paragraaf 3.3 niet Same As 
Before gehanteerd, maar wordt gekeken naar de gemiddelde voorspelde uitstroom. Ook deze referentieprognose is in de tabel te vinden. Over het algemeen is de voorspelde uitstroom lager dan de gerealiseerde uitstroom. Kennelijk is de baan-baan-mobiliteit toegenomen, of is er sprake van een toenemend percentage werkenden dat de arbeidsmarkt verlaat. De grootste voorspelfouten betreffen dan ook de onderschattingen van de uitstroom. De grootste uitschieters zijn zelfstandige winkeliers (beroepsklasse 43), leidinggevend huishoudelijk personeel (beroepsklasse 52), glas- en aardewerkvormers (beroepsklasse 89), computerapparatuuroperateurs (beroepsklasse 34), bedrijfsleider land- en tuinbouw (beroepsklasse 60), en boswachters en bosarbeiders (beroepsklasse 63). Een aantal van deze uitschieters (naar boven) bleek bij de evaluatie van de werkgelegenheidsontwikkeling per beroepsklasse (paragraaf 4.3) een uitschieter naar beneden te zijn. Dit bevestigt het vermoeden dat er een negatieve samenhang bestaat tussen voorspelfouten bij de werkgelegeheidsontwikkeling en de vervangingsvraag. Deze negatieve correlatie zal er overigens toe leiden dat bij de prognoses van baanopeningen fouten bij deze afzonderlijke componenten deels tegen elkaar weg zullen vallen.

Tabel 4.13. Voorspelfouten van de uitstroom per beroepsklasse

\begin{tabular}{|c|c|c|c|c|c|}
\hline Beroepsklasse & referentie & prognose & realisatie & voorspelfout & verlies \\
\hline 01 Schei-, natuurkundigen e.a. technici & 6.000 & 5.400 & 11.300 & -5.900 & 0,0232 \\
\hline 02 Ingenieurs, tekenaars e.d. & 31.600 & 21.400 & 71.900 & -50.500 & 0,0444 \\
\hline 04 Vliegtuig- en scheepsofficieren & 3.000 & 2.700 & 8.000 & -5.300 & 0,1419 \\
\hline 05 Bioloog, biochemicus, landbouwkundige & 5.200 & 2.600 & 8.800 & -6.200 & 0,0280 \\
\hline 06 Medisch- en paramedisch personeel & 47.300 & 26.700 & 37.800 & -11.100 & 0,0008 \\
\hline 08 Wiskundigen, systeemanalisten e.d. & 9.000 & 1.500 & 5.300 & -3.800 & 0,0009 \\
\hline 09 Econoom & 2.700 & 1.800 & 5.600 & -3.800 & 0,0236 \\
\hline 11 Accountant, belastingconsulent & 2.200 & 2.000 & 3.300 & -1.300 & 0,0020 \\
\hline 12 Jurist, notaris, rechter & 3.300 & 1.500 & 4.300 & -2.800 & 0,0081 \\
\hline 13 Onderwijzend personeel & 48.800 & 30.300 & 26.900 & 3.400 & 0,0001 \\
\hline 14 Theoloog, dominee, pastor e.d. & 1.800 & 1.500 & 3.400 & -1.900 & 0,0302 \\
\hline 15 Journalist, auteur, redacteur e.d. & 3.500 & 1.200 & 4.400 & -3.200 & 0,0067 \\
\hline 16 Kunstenaar, ontwerper, fotograaf filmer & 5.200 & 5.300 & 6.000 & -700 & 0,0002 \\
\hline 17 Musicus, dirigent, toneelspeler e.d. & 3.000 & 1.500 & 7.900 & -6.400 & 0,0983 \\
\hline 18 Beroepssporter, trainer, sportleraar & 1.800 & 1.600 & 4.700 & -3.100 & 0,0396 \\
\hline 19 Sociale hulpverleners, vertalers e.d. & 19.200 & 9.700 & 17.500 & -7.800 & 0,0021 \\
\hline 20 Hogere leid. functies bij openb. bestuur & 800 & 1.200 & 2.700 & -1.500 & 0,0633 \\
\hline 21 Beleidvoerende en hogere leid. functies & 28.900 & 19.600 & 47.400 & -27.800 & 0,0104 \\
\hline 30 Leidinggevend administratief personeel & 3.100 & 4.200 & 14.600 & -10.400 & 0,1044 \\
\hline 31 Uitvoerend hoofdambtenaar & 2.900 & 3.600 & 5.800 & -2.200 & 0,0095 \\
\hline 32 Secretaresse, typist, datatypist e.d. & 26.100 & 32.400 & 44.400 & -12.000 & 0,0065 \\
\hline 33 Bankemployé, lokettisten e.d. & 51.700 & 46.600 & 60.400 & -13.800 & 0,0012 \\
\hline 34 Computerapparatuur-operateurs e.d. & 2.000 & 2.500 & 7.400 & -4.900 & 0,4270 \\
\hline 35 Leidinggevend personeel transportbedrijf & 4.800 & 4.600 & 14.900 & -10.300 & 0,2558 \\
\hline 36 Conducteur & 400 & 600 & 1.300 & -700 & 0,0283 \\
\hline 37 Postsorteerder, postbesteller e.d. & 7.800 & 4.800 & 14.500 & -9.700 & 0,0392 \\
\hline 38 Telefonist, telegrafist & 3.200 & 3.600 & 9.200 & -5.600 & 0,2217 \\
\hline 39 Diverse administratieve functies & 67.200 & 60.600 & 82.100 & -21.500 & 0,0022 \\
\hline 40 Directeur en bedrijfsleider groothandel & 5.400 & 2.400 & 7.900 & -5.500 & 0,0173 \\
\hline 41 Directeur en bedrijfsleider detailhandel & 2.900 & 1.700 & 9.500 & -7.800 & 0,1336 \\
\hline 42 Zelfst. groothandelaar, tussenhandelaar & 3.800 & 3.000 & 7.000 & -4.000 & 0,0178 \\
\hline
\end{tabular}


Tabel 4.13. Voorspelfouten van de uitstroom per beroepsklasse (vervolg)

\begin{tabular}{|c|c|c|c|c|c|}
\hline Beroepsklasse & referentie & prognose & realisatie & voorspelfout & verlies \\
\hline 43 Zelfstandige winkeliers & 14.500 & 18.000 & 62.800 & -44.800 & 1,3380 \\
\hline 45 Verkoopchef, filiaalhouder, inkoper e.d. & 7.900 & 10.700 & 15.800 & -5.100 & 0,0091 \\
\hline 46 Vertegenwoordiger & 8.900 & 7.600 & 18.800 & -11.200 & 0,0503 \\
\hline 47 Verzekeringsagenten, makelaars e.d. & 6.100 & 5.500 & 7.900 & -2.400 & 0,0017 \\
\hline 48 Winkelbediende, marktverkoper e.d. & 41.100 & 48.700 & 63.500 & -14.800 & 0,0011 \\
\hline 50 Directeur/bedrijfsleider horecabedrijf & 2.300 & 4.200 & 4.400 & -200 & 0,0001 \\
\hline 51 Zelfstandig hotel-, rest-, caféhouder & 5.300 & 6.900 & 17.100 & -10.200 & 0,2708 \\
\hline 52 Leidinggevend huishoudelijk personeel & 1.800 & 1.800 & 8.800 & -7.000 & 0,6679 \\
\hline 53 Kok, kelner, buffetbediende e.d. & 19.200 & 16.200 & 20.400 & -4.200 & 0,0005 \\
\hline 54 Huishoudelijk- en verzorgend personeel & 32.000 & 28.900 & 29.300 & -400 & 0,0000 \\
\hline 55 Huisbewaarders en schoonmaakpersoneel & 24.300 & 17.800 & 19.700 & -1.900 & 0,0001 \\
\hline 56 Wasser, perser & 1.800 & 2.800 & 6.400 & -3.600 & 0,1998 \\
\hline 57 Kapper, schoonheidsspecialist & 5.500 & 4.900 & 12.300 & -7.400 & 0,0330 \\
\hline 58 Brandweer-, politiepersoneel, bewakers & 9.900 & 6.100 & 11.700 & -5.600 & 0,0068 \\
\hline 59 Diverse commerciele functies & 5.100 & 5.500 & 9.000 & -3.500 & 0,0093 \\
\hline 60 Bedrijfsleider land- en tuinbouw & 1.100 & 1.000 & 5.000 & -4.000 & 0,3778 \\
\hline 61 Zelfstandige land- en tuinbouwers & 22.900 & 22.000 & 49.100 & -27.100 & 0,0672 \\
\hline 62 Agrarische arbeiders & 23.200 & 31.400 & 38.200 & -6.800 & 0,0019 \\
\hline 63 Boswachter en bosarbeider & 700 & 1.000 & 2.500 & -1.500 & 0,3632 \\
\hline 64 Visser, jager & 600 & 800 & 1.600 & -800 & 0,0249 \\
\hline 70 Leidinggevend produktiepersoneel & 17.800 & 20.100 & 40.700 & -20.600 & 0,0067 \\
\hline 71 Mijn-, groeve-arbeider, boortechnici & 300 & 600 & 1.000 & -400 & - \\
\hline 72 Hoogovenarbeiders, walsers, gieters e.d. & 2.400 & 2.400 & 6.400 & -4.000 & 0,0881 \\
\hline 73 Houtzager, papiermaker & 1.300 & 2.500 & 3.900 & -1.400 & 0,0494 \\
\hline 74 Chemische procesarbeiders & 4.300 & 4.100 & 6.500 & -2.400 & 0,0069 \\
\hline 75 Spinners, wevers e.d. & 2.000 & 5.300 & 6.300 & -1.000 & 0,0110 \\
\hline 77 Voedingsmiddelen, drankbereider & 10.700 & 12.100 & 18.100 & -6.000 & 0,0074 \\
\hline 78 Tabakbewerker, tabakproduktenmaker & 400 & 100 & 1.600 & -1500 & - \\
\hline 79 Kleermakers, stoffeerders e.d. & 5.800 & 8.400 & 10.100 & -1.700 & 0,0022 \\
\hline 80 Schoenmaker, ledermaker & 1.400 & 1.700 & 4.400 & -2.700 & 0,1449 \\
\hline 81 Meubelmaker en andere houtbewerkers & 3.200 & 6.600 & 6.100 & 500 & 0,0005 \\
\hline 83 Smeden, gereedschapsmakers e.d. & 7.300 & 13.600 & 8.700 & 4.900 & 0,0083 \\
\hline 84 Instrumentmakers, monteurs e.d. & 27.600 & 32.600 & 38.600 & -6.000 & 0,0013 \\
\hline 85 Electromonteurs, -reparateurs & 19.500 & 18.700 & 38.300 & -19.600 & 0,0267 \\
\hline 86 Geluids-, beeldapparatuurbedieners & 400 & 0 & 2.100 & -2100 & - \\
\hline 87 Loodgieter, pijpfitter, lasser e.d. & 18.500 & 34.500 & 21.800 & 12.700 & 0,0118 \\
\hline 88 Goud- en zilversmeden, diamantbewerkers & 400 & 300 & 1.900 & -1600 & - \\
\hline 89 Glas-, aardewerkvormer e.d. functies & 1.700 & 2.400 & 7.000 & -4.600 & 0,4924 \\
\hline 90 Rubber-, plasticproduktenmaker & 2.400 & 2.800 & 7.000 & -4.200 & 0,0675 \\
\hline 91 Papierwaren-, kartonnagewerker & 1.000 & 700 & 3.200 & -2.500 & 0,2182 \\
\hline 92 Drukker en verwante functies & 7.700 & 7.800 & 12.700 & -4.900 & 0,0076 \\
\hline 93 Schilder e.d. & 7.000 & 9.400 & 7.300 & 2.100 & 0,0022 \\
\hline 94 Ambachts- en industrieberoepen n.e.g. & 2.300 & 4.500 & 4.100 & 400 & 0,0006 \\
\hline 95 Metselaar, timmerman,e.a. bouwvakkers & 30.000 & 57.500 & 30.700 & 26.800 & 0,0200 \\
\hline 96 Machinisten e.a. bedieners van machines & 1.100 & 1.600 & 3.100 & -1.500 & 0,1063 \\
\hline 97 Laders, lossers, inpakkers e.d. & 28.300 & 27.100 & 47.600 & -20.500 & 0,0137 \\
\hline 98 Chauffeurs, matrozen, treinbestuurders & 26.200 & 32.500 & 21.600 & 10.900 & 0,0028 \\
\hline 99 Sjouwers, dokwerkers e.d. & 8.000 & 18.100 & 33.700 & -15.600 & 0,1819 \\
\hline
\end{tabular}


In tabel 4.14 wordt een overzicht gegeven van de voorspelkwaliteit van de uitstroomprognoses. De voorspellingen worden zowel met de gerealiseerde vervangingsvraag als met de gerealiseerde uitstroomcijfers vergeleken. Uit het feit dat de kwaliteits-score bij de uitstroom veel beter is dan bij de vervangingsvraag kan worden opgemaakt dat de hier geëvalueerde prognoses inderdaad betrekking hebben op uitstroomprognoses en derhalve geen echte vervangingsvraagprognoses zijn. Opmerkelijk is dat het gemiddeld verlies van de prognoses bij de vervangingsvraag aanmerkelijk kleiner is dan bij een vergelijking met de uitstroom. Ook de referentieprognose heeft hier een veel kleiner gemiddeld verlies. Dit wijst er op dat de vervangingsvraag een veel stabielere grootheid is dan de uitstroom. De aanpak van Willems en De Grip (1990) om in plaats van de uitstroom de vervangingsvraag te extrapoleren blijkt dus inderdaad zinvol te zijn.

De gedachte dat de vervangingsvraag voor de prognoses van baanopeningen een belangrijkere component is dan de uitbreidingsvraag wordt overigens niet bevestigd door de cijfers. In absolute termen kan het weliswaar gaan om een redelijk grote component, de relevantie van prognoses wordt echter bepaald door de veranderlijkheid.

Tabel 4.14. Totaal-overzicht voorspelkwaliteit uitstroomprognoses per beroepsklasse.

$\begin{array}{lll}\text { Methode } & \text { gemiddeld verlies } & \text { gemiddeld verlies } \\ \text { prognose } & \text { referentie }\end{array}$

\begin{tabular}{|c|c|c|c|c|}
\hline \multicolumn{5}{|c|}{ Vervangingsvraag } \\
\hline \multicolumn{2}{|c|}{ absoluut } & 0,0065 & 0,0037 & 1,78 \\
\hline \multicolumn{2}{|c|}{ relatief } & 0,0074 & 0,0034 & 2,17 \\
\hline \multicolumn{5}{|c|}{ Uitstroom } \\
\hline \multicolumn{2}{|c|}{ absoluut } & 0,0244 & 0,0269 & 0,91 \\
\hline \multicolumn{2}{|c|}{ relatief } & 0,0180 & 0,0181 & 1,00 \\
\hline \multicolumn{5}{|c|}{ Per beroepstak (relatief) } \\
\hline $0 / 1$ & wetenschappelijke e.a. vakspecialisten, kunstenaars & 0,0078 & 0,0102 & 0,76 \\
\hline 2 & beleidvoerende en hogere leidinggevende functies & 0,0043 & 0,0015 & 2,83 \\
\hline 3 & administratieve functies & 0,0085 & 0,0106 & 0,80 \\
\hline 4 & commerciële functies & 0,0492 & 0,0604 & 0,81 \\
\hline 5 & dienstverlenende functies & 0,0113 & 0,0178 & 0,63 \\
\hline 6 & agrarische beroepen, vissers e.d. & 0,0185 & 0,0159 & 1,17 \\
\hline $7-9$ & ambachts-, industrie, transportberoepen e.d. & 0,0259 & 0,0152 & 1,70 \\
\hline
\end{tabular}

Een vergelijking met tabel 4.8 laat zien dat de veranderlijkheid van de uitstroom (dat is het gemiddeld verlies van de referentie-prognose) zowel bij de absolute als bij de relatieve maatstaf slechts zo'n $25 \%$ van de veranderlijkheid van de uitbreidingsvraag is. Bij de overgang van uitstroom naar vervangingsvraag reduceert dit percentage zelfs tot $4 \%$. Het hanteren van vervangingsvraagprognoses in plaats van uitstroomprognoses brengt op zich zelf dus al een grote verbetering van de voorspelkwaliteit met zich mee, zelfs al zou eenvoudigweg de referentieprognose gehanteerd worden. Bovendien heeft een negatieve uitbreidingsvraag, bij het hanteren van de vervangingsvraag 
voor het berekenen van de baanopeningen, geen invloed op het voorspelde aantal baanopeningen. Bij een negatieve uitbreidingsvraag kunnen in die situatie dus alleen nog voorspelfouten optreden indien ten onrechte een groei voorspeld wordt. Fouten in de prognose van de omvang van de krimp van de werkgelegenheid spelen geen rol meer bij het voorspellen van de baanopeningen.

Uit de tabel kan verder opgemaakt worden dat de prognoses van de uitstroom relatief matig waren. Dit zal ten eerste veroorzaakt zijn doordat de prognoses gebaserd zijn op een extrapolatie van uitstroomcijfers in plaats van vervangingsvraagcijfers. Figuur 4.4 laat het verband zien tussen enerzijds uitbreidingsvraag en uitstroom en anderzijds uitbreidingsvraag en vervangingsvraag in de periode 1985-1992 ${ }^{21}$. Zowel op de negatieve als op de positieve waarnemingen van de uitbreidingsvraag is een regressievergelijking geschat. De resultaten hiervan staan in tabel 4.15 en zijn weergegeven in de figuur. Het blijkt dat het door Willems en De Grip (1990) veronderstelde verband tussen uitstroom en uitbreidingsvraag adequater is dan het bij de prognoses van 1989 gehanteerde verband. Op het positieve segement wordt geen significant verband tussen uitbreidingsvraag en uitstroom gevonden, terwijl op het negatieve segment er inderdaad een negatief verband bestaat. De richtingcoëfficiënt is volgens de regressie echter groter dan de -1 die verondersteld wordt door Willems en De Grip. Dit kan veroorzaakt zijn door meetfouten in de uitbreidingsvraag of kan betekenen dat een krimp in de werkgelegenheid voor een deel toch wordt afgewenteld op degenen die instromen op de arbeidsmarkt.

Figuur 4.4. Verband tussen uitbreidingsvraag en uitstroom bij beroepsklassen tussen 1985 en 1992

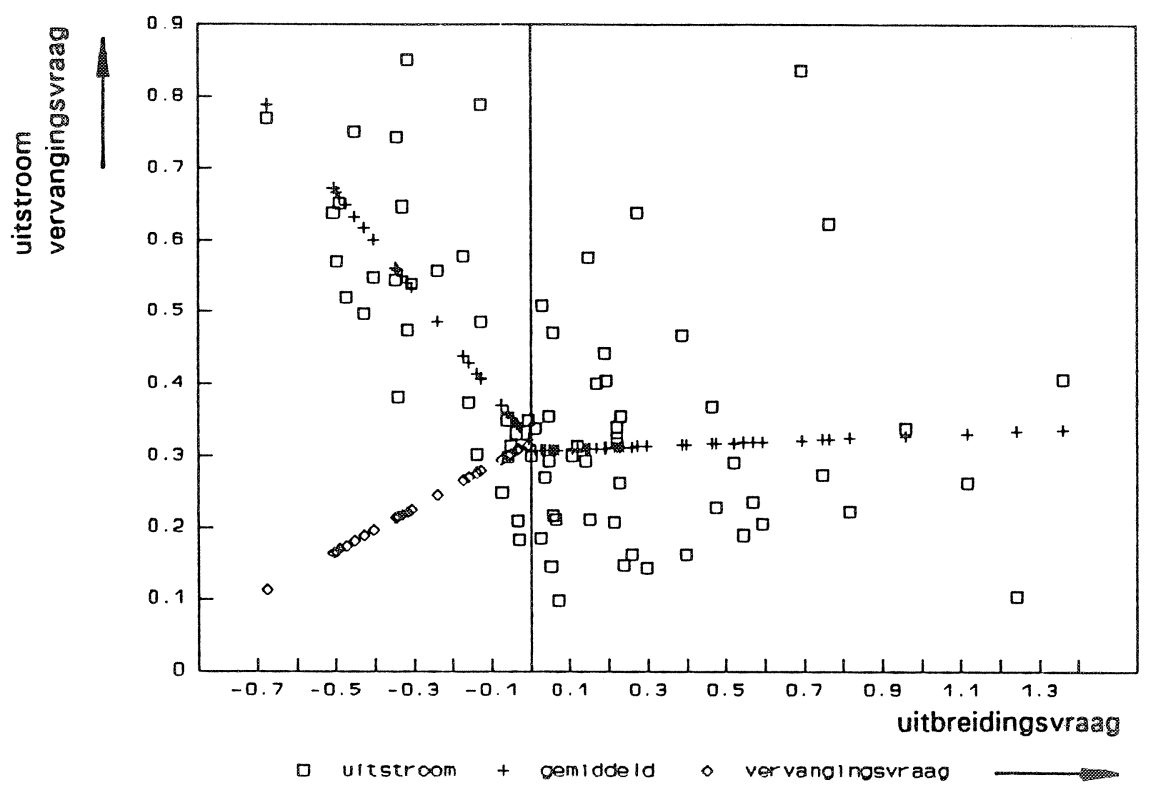

21. Vanwege het verschil in de gehanteerde urengrens is bij de uitbreidingsvraag $15 \%$ groei in mindering gebracht om de groeicijfers van beide werkgelegenheidsdefinities vergelijkbaar te maken. 
Tabel 4.15. Verband tussen uitstroompercentages en uitbreidingsvraag tussen 1985 en 1992 t-waardes tussen haakjes

negatieve segment

$0,32(2,35)$

Constante

Uitbreidingsvraag
$-0,70(5,05)$ positieve segment
$(2,01)$

$0,02(0,33)$

In tabel 4.14 vindt verder nog een opsplitsing van de voorspelfouten per beroepstak plaats. De gehanteerde prognosemethode scoort relatief slecht bij de leidinggevende beroepen (dit zijn slechts twee beroepsklassen), en bij de conjunctuurgevoelige agrarische en industriële beroepen. Goede scores worden daarentegen bereikt bij de commerciële, dienstverlenende en administratieve beroepen. In deze beroepen werken relatief veel vrouwen. De prognosemethodiek blijkt dus, vergeleken met de referentieprognose, vooral de meer systematische component in de uitstroompercentages goed te voorspellen, maar schiet tekort ten aanzien van de conjuncturele invloeden.

\section{Een verklaring van de voorspelfout}

Impliciet in de prognoses van de uitstroom zit de aanname dat de uitstroomcurve het verloop heeft zoals aangegeven in figuur 2.2. Indien, zoals in bovenstaande analyse getoond is, de feitelijke uitstroomcurve hiervan afwijkt, zullen prognoses van de uitstroom vooral een grote voorspelfout vertonen als de uitbreidingsvraag in de prognoseperiode sterk afwijkt van de uitbreidingsvraag in de observatieperiode. Als verklarende variabele om de standaarddeviatie van de voorspelfout te verklaren is in tabel 4.16 derhalve het absolute verschil van beide groeivoeten opgenomen. Hierbij is een correctie aangebracht voor de totale groei van de werkgelegenheid in de betreffende periode, omdat deze algehele correctie ook bij de prognoses heeft plaatsgevonden. De tabel laat zien dat deze factor inderdaad een zeer belangrijke en zeer significante verklarende variabele is voor de voorspelfouten bij de uitstroom per beroepsklasse.

Tabel 4.16. Een verklaring van de standaarddeviatie van de voorspelfouten van de uitstroom per beroepsklasse.

$\begin{array}{lrr}\text { Variabele } & \text { parameter } & t \text {-waard } \\ & & \\ & & \\ \text { Schaal } & 0,78 & 12,26 \\ \text { Constante } & -0,63 & 0,83 \\ \text { Conjunctuur } & 0,08 & 5,04 \\ \text { Uitwijkmogelijkheden } & -0,60 & 2,64 \\ \text { Verandering uitbreidingsvraag } & 13,09 & 6,05\end{array}$


Het schaaleffect is overeenkomstig de bevindingen bij de uitbreidingsvraag per beroepsklasse en bedrijfssector. Grote beroepsklassen worden relatief beter voorspeld dan kleinere beroepsklassen. Verder zijn, net als bij de uitbreidingsvraag per beroepsklasse, de risico-indicatoren als verklarende variabele van de voorspelfout opgenomen. In tegenstelling tot de analyse bij de uitbreidingsvraag hebben beide risico-indicatoren hier wel een significante samenhang met de voorspelfout. Bij een grotere conjunctuurgevoeligheid blijkt de uitstroom slechter voorspeld te zijn, terwijl bij beroepsklassen waar sprake is van meer uitwijkmogelijkheden, de uitstroom beter is voorspeld. Door de grotere uitwijkmogelijkheden zijn mensen kennelijk in staat bij werkgelegenheidsproblemen uit te wijken naar andere bedrijfssectoren, waardoor ze in hun eigen beroep werkzaam kunnen blijven.

\section{Overschatting van afwijkingen}

Tabel 4.17. De overschatting van veranderingen bij de relatieve uitstroomprognoses per beroepsklasse

onderschattingscoëfficiënt t-waarde
Totaal
$-0,60$
5,10

Ook is onderzocht in hoeverre er sprake is van een over- of onderschatting van de waargenomen veranderingen. Omdat bij de vervangingsvraag de referentieprognose niet gelijk is aan de situatie in het verleden (SAB), maar aan de gemiddelde voorspelde vervangingsvraag, wordt in dit geval niet de onder- of overschatting van veranderingen gemeten, maar wordt de onder- of overschatting van afwijkingen van het gemiddelde geanalyseerd. Tabel 4.17 laat zien dat er bij de uitstroomprognoses per beroepsklasse sprake is van een overschatting van afwijkingen. Zoals in paragraaf 3.4 werd opgemerkt moet dit verschijnsel niet geïnterpreteerd worden alsof de werkelijke veranderingen met een vermenigvuldigingsfactor in de prognoses verwerkt zijn. Het negatieve teken van de onderschattingsparameter betekent dat de prognose bestaat uit een werkelijk informatief prognosegedeelte en uit een additionele storingsterm. Door de voorspelde veranderingen in te krimpen tot $40 \%$ van hun omvang reduceert zowel de informative waarde van de prognoses als de ruis hierin. Aanvankelijk - tot aan de $40 \%$ - is de vermindering van de storing echter dominant, zodat er per saldo een verbetering plaatvindt.

Deze ruis in de prognoses zal zowel veroorzaakt zijn door het feit dat de prognoses op slechts één historische waarnemingsperiode berusten, maar ook doordat er grote veranderingen kunnen hebben plaatsgevonden in de werkgelegenheidsontwikkeling van de beroepsklasse. Hierdoor krijgt de gemiddelde uitstroomprognose (onder gemiddelde omstandigheden) toegevoegde waarde ten opzichte van de beroepsspecifieke uitstroomprognose die gebaseerd is op een inmiddels gewijzigde werkgelegenheidsontwikkeling. 


\section{Kwalitatieve typeringen}

Evenals bij de uitbreidingsvraag is ook bij de vervangingsvraag per beroepsklasse een kwalitatieve typering gemaakt, om daarmee de prognose beter interpreteerbaar te maken en het onzekere karakter van de prognose tot uitdrukking te brengen. De indeling van de kwalitatieve typeringen is als volgt:

VBK $\leq 10 \%$ erg laag
$10 \%<$ VBK $\leq 17 \%$ laag
$17 \%<$ VBK $\leq 19 \%$ gemiddeld
$19 \%<$ VBK $\leq 25 \%$ hoog
$25 \%<$ VBK $\quad$ erg hoog

waarbij VBK staat voor vervangingsvraag (eigenlijk dus uitstroom) per beroepsklasse (De Grip e.a., 1989, blz. 10).

Tabel 4.18. Typeringen van de uitstroom per beroep en de realisaties (relatief)

\begin{tabular}{|c|c|c|c|c|c|c|}
\hline Realisatie & erg laag & laag & $\begin{array}{l}\text { prognose } \\
\text { gemiddeld }\end{array}$ & hoog & erg hoog & totaal \\
\hline Erg laag & 2 & 2 & 0 & 1 & 0 & 5 \\
\hline Laag & 4 & 7 & 1 & 2 & 3 & 17 \\
\hline Gemiddeld & 0 & 2 & 1 & 2 & 0 & 5 \\
\hline Hoog & 1 & 9 & 1 & 4 & 4 & 19 \\
\hline Erg hoog & 4 & 9 & 1 & 10 & 9 & 33 \\
\hline Totaal & 11 & 29 & 4 & 19 & 16 & 79 \\
\hline
\end{tabular}

Tabel 4.18 geeft aan op welke wijze bepaalde typeringen zich gerealiseerd hebben. 23 van de 79 (29\%) beroepsklassen hebben een juiste typering van de uitstroom gekregen. 26 beroepsklassen zijn slechts één kwalitatieve typering te hoog of te laag voorspeld. In totaal is er dus bij $62 \%$ van de beroepsklassen een geheel of bijna juiste typering gemaakt. Opvallend hoog is echter het aantal beroepsklassen dat een typering gekregen heeft die de verkeerde richting aangeeft. In totaal gaat het hier om 29 beroepsklassen (37\%). In 6 gevallen werd een hoge of erg hoge typering gegeven, terwijl deze laag of erg laag had moeten zijn. In 23 gevallen is het omgekeerde het geval. De vier extreemste typeerfouten zijn musicus, dirigent, toneelspeler e.d. (beroepsklasse 17), directeur en bedrijfsleider detailhandel (beroepsklasse 41), tabakbewerker, tabakproduktenmaker (beroepsklasse 78) en geluids-, beeldapparatuurbedienders (beroepsklasse 86). Deze uitschieters lijken met name veroorzaakt te zijn door meetonzekerheid. Met name de laatste twee beroepsklassen zijn zeer klein. Dit laat nogmaals zien dat de stabiliteit van de prognoses de nodige aandacht verdient.

In bijlage II staan voor alle beroepsklassen afzonderlijk de voorspelde en de gerealiseerde typering van de uitstroom per beroepsklasse. Verder bevat de tabel weer de standaarddeviatie per beroepsklasse, de kans op een juiste voorspelling bij een symmetrisch interval, bij een willekeurige positie binnen dit interval en de kans op een juiste typering bij het feitelijk gekozen interval. 
Tabel 4.19 laat zien dat bij een symmetrisch interval naar verwachting $46 \%$ van de typeringen juist zou zijn geweest. Doordat de puntschattingen op een willekeurige positie in het typeringsinterval liggen, reduceert de kans op een juiste typering tot $34 \%$. Dit komt doordat soms een puntschatting op de grens van het interval ligt, zodat bij een kleine afwijking van realisatie en prognose de typering al onjuist kan zijn. Doordat de twee buitenste feitelijke intervallen 'erg hoog' en 'erg laag' aan één zijde onbegrensd zijn, wordt de kans op een juiste typering echter weer hoger, namelijk $47 \%$. Het feitelijk resultaat is echter slechts $36 \%$. Deze onverwacht lage score moet het gevolg zijn van het toeval. De $36 \%$ juiste typeringen in de tabel is overigens nog hoger dan de $29 \%$ die voortkomt uit tabel 4.18. Dit komt doordat de totaalresultaten in tabel 4.19 zijn gewogen naar beroepsklasse-omvang en de grotere beroepsklassen beter voorspeld zijn dan de kleinere.

Tabel 4.19. De gemiddelde trefkans bij verschillende soorten intervallen voor de typering van de vervangingsvraag per beroepsklasse

Intervalkeuze

gemiddelde trefkans

$\%$

Symmetrisch

Willekeurige positie binnen begrensd interval

Figuur 4.5 geeft een beeld van de samenhang tussen de kans op een juiste typering en de standaarddeviatie. De figuur geeft zowel de trefkans bij een symmetrisch als ook bij het feitelijk gehanteerde interval aan. Omdat de standaarddeviatie substantieel kleiner is dan bij de uitbreidingsvraag is hierin duidelijk te zien dat bij een symmetrisch interval de trefkans veel groter zou zijn geweest dan bij de intervalindeling die gehanteerd is, tenzij er sprake is van een van de extreme typeringen, 'erg laag' of 'erg hoog'. De trefkans bij deze beroepsklassen ligt veel hoger dan bij de overige beroepsklassen, doordat de intervallen van deze extreme typeringen naar één kant onbegrensd zijn. De overige beroepsklassen liggen per typering ongeveer op één curve. De hoogste curves betreffen de typeringen 'laag' en 'hoog'. Deze hebben een interval dat respectievelijk 6 en $7 \%$ breed is. De typeringen 'gemiddeld' zitten daarentegen in een interval met een breedte van slechts $2 \%$. Hierbij is duidelijk de kans op een juiste typering aanmerkelijk lager.

Verder valt op dat de spreiding van de standaarddeviatie bij de uitstroomprognoses veel groter is dan bij de uitbreidingsvraagprognoses. Dit komt doordat de beroepsklassen waarbij de uitbreidingsvraag geen grote verandering heeft ondergaan veel beter voorspeld zijn dan de overige beroepsklassen. Indien de prognosemethodiek deze tekortkoming kan overbruggen en op een juiste manier rekening houdt met het verband tussen werkgelegenheidsontwikkeling en uitstroom komt de trefzekerheid duidelijk op een aanvaardbaar niveau te liggen. Als verder ook maatregelen worden getroffen tegen de meetonzekerheid blijkt het mogelijk te zijn om bij een intervallengte van $6-7 \%$ een trefkans van $70 \%$ te bereiken. 
Figuur 4.5. Kans op een juiste kwalitatieve typering bij symmetrische en werkelijke intervallen bij de vervangingsvraag per beroep

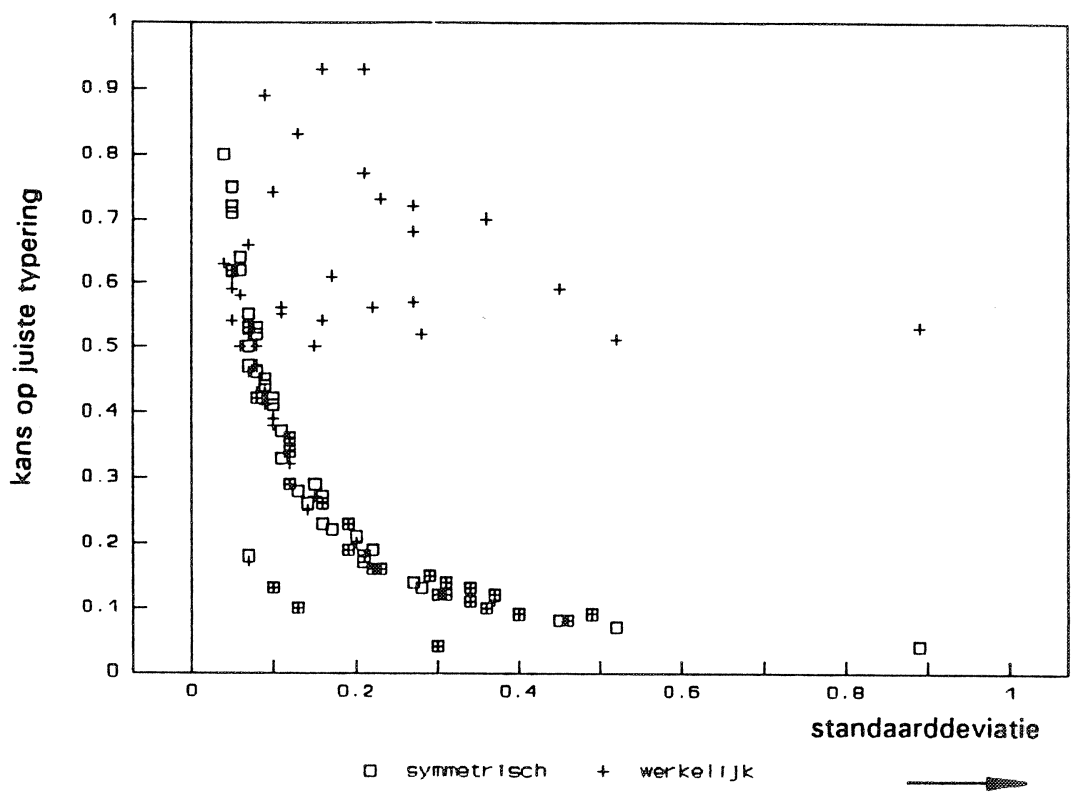

\section{Conclusies}

De analyse in deze paragraaf laat zien dat de hier geëvalueerde vervangingsvraagprognoses twee belangrijke tekortkomingen hadden. Ten eerste is bij de extrapolatie van de uistroomcoëfficiënten onvoldoende rekening gehouden met de relatie tussen de uitstroom en de werkgelegenheidsontwikkeling. De huidige methodiek waarbij de extrapolatie via de vervangingsvraag loopt, is in dit opzicht al een aanmerkelijke verbetering. Verder onderzoek naar de uitstroomcurve zou deze methodiek ter bepaling van de vervangingsvraag nog verder kunnen verbeteren.

Ten tweede blijken de prognoses instabiel te zijn doordat ze gebaseerd zijn op slechts één waarnemingsperiode van de uitstroom. Deze waarnemingen zijn bovendien zelf instabiel doordat ze gebaseerd zijn op betrekkelijk kleine fracties van de steekproef. Door de prognoses te baseren op meerdere waarnemingspunten - wat mogelijk lijkt te worden nu er meer jaargangen van AKT en EBB beschikbaar zijn - en door in de methodologie uitdrukkelijk rekening te houden met de meetfouten kan mogelijk ook op dit punt een verbetering van de prognoses worden gerealiseerd.

\subsection{Baanopeningen per beroepsklasse}

De mogelijkheden voor nieuwkomers op de arbeidsmarkt om werk te vinden binnen een bepaalde beroepsklasse worden bepaald door de baanopeningen, het totaal van uitbreidings- en vervangingsvraag. Omdat echter de relatie tussen beide vraagcomponenten en het totaal aantal baanopeningen definitorisch is, is er met het oogpunt op het verbeteren van de methodiek geen aanleiding om de prognoses van de baanopeningen zelf uitvoerig te evalueren. De evaluatie in deze 
paragraaf kan daarom beperkt blijven tot een bepaling van de totale voorspelfout bij de baanopeningen per beroepsklasse en een beschouwing van de trefzekerheid van de typeringen. Omdat een afzonderlijke specificatie van de standaardfout van de voorspellingen van baanopeningen ontbreekt, maar ook omdat de kwalitatieve typering van baanopeningen in feite bepaald zou moeten worden door de typeringen van de afzonderlijke componenten, zal er ook geen verdergaande analyse van deze typeringen plaatsvinden.

De kwaliteit van de prognoses van het aantal baanopeningen wordt vanzelfsprekend bepaald door de kwaliteit van de afzonderlijke delen. In paragraaf 2.5 werd echter geconstateerd dat er een negatieve correlatie zal bestaan tussen de uitbreidingsvraag en de uitstroom van werkenden. Als er krimp in de werkgelegenheid is, zal de uitstroom toenemen. Dat betekent ook dat als de uitbreidingsvraag meer afneemt dan voorzien, de uitstroom groter zal zijn dan voorzien. Ook tussen de voorspelfouten van beide vraagcomponenten kan daarom een negatieve correlatie verwacht worden. Grote voorspelfouten bij de ene component worden dan gecompenseerd door kleine voorspelfouten bij het andere onderdeel van de prognose van de totale vraag naar nieuwkomers op de arbeidsmarkt. Tabel 4.20 laat zien dat er inderdaad sprake is van een dergelijke negatieve correlatie. Als de beide fouten onderling onafhankelijk zouden zijn geweest zou het totale gemiddelde verlies bij de baanopeningen gelijk zijn geweest aan 0,0907, de som van het gemiddeld verlies van de vraagcomponenten. Er blijkt echter sprake te zijn van een negatieve correlatie van $-0,0142$, zodat het uiteindelijke gemiddelde verlies van de prognoses van de baanopeningen per beroepsklasse gelijk is aan $0,0623^{22}$. Het gemiddeld verlies van de prognoses van de baanopeningen is dus nog kleiner dan het gemiddeld verlies bij alleen de uitbreidingsvraag.

Tabel 4.20. Opbouw van het gemiddeld verlies van de prognose van baanopeningen per beroepsklasse

Onderdeel gemiddeld verlies

$\begin{array}{lr}\text { Uitbreidingsvraag } & 0,0727 \\ \text { Uitstroom } & 0,0180 \\ \text { Correlatie } & -0,0142 \\ \text { Totaal baanopeningen } & 0,0623\end{array}$

Voor de kwalitatieve typering van de prognoseresultaten is een vijfdeling gemaakt op basis van de volgende indeling:

$\begin{aligned} \text { TBK } \leq 14 \% & \text { erg laag } \\ 14 \%<\text { TBK } \leq 24 \% & \text { laag } \\ 24 \%<\text { TBK } \leq 34 \% & \text { gemiddeld } \\ 34 \%<\text { TBK } \leq 44 \% & \text { hoog } \\ 44 \%<\text { TBK } & \text { erg hoog }\end{aligned}$

waarbij TBK staat voor baanopeningen in een beroepsklasse (De Grip e.a., 1989, blz. 11).

22. Omdat $\operatorname{Var}(a+b)=\operatorname{Var}(a)+\operatorname{Var}(b)+2 \operatorname{Cov}(a, b)$. 
Tabel 4.21 geeft een matrix van de gegeven kwalitatieve typeringen en hun realisaties. Uit de tabel blijkt dat de trefzekerheid van de typeringen van de baanopeningen groter is dan die van de uitbreidingsvraag. Dit komt enerzijds door de kleinere voorspelfout bij de baanopeningen en anderzijds door de bredere intervallen die gehanteerd zijn voor het toekennen van de kwalitatieve typeringen. Uit de tabel valt af te lezen dat 26 van de 79 beroepsklassen exact de juiste typering hebben gekregen. Dit is $33 \%$ van het totaal aantal beroepsklassen. Inclusief de beroepsklassen waarbij de realisatie slechts één typering naast de gegeven typering ligt is in totaal voor 50 van de 79 beroepsklassen een redelijk juiste typering gegeven (63\%).

Er komen echter ook enkele uitschieters voor. De beroepsklassen journalisten, auteurs, redacteurs e.d. (beroepsklasse 15) en leidinggevend produktiepersoneel (beroepsklasse 70) blijken een erg groot aantal baanopeningen te hebben, terwijl het voorspelde aantal baanopeningen erg laag was. De omgekeerde uiterste situatie komt niet voor. In totaal is er voor 12 beroepsklassen een relatief laag of erg laag aantal baanopeningen voorspeld, terwijl deze beroepsklassen achteraf bezien hoog of zeer hoog als typering hadden moeten krijgen. Daarentegen zijn er 12 beroepsklassen waarbij juist een groot of erg groot aantal baanopeningen voorspeld werd, waarvan het aantal baanopeningen feitelijk laag of erg laag bleek te zijn. Al met al is derhalve bij $30 \%$ van de beroepsklassen een typering gegeven die achteraf bezien aan de verkeerde kant van het 'gemiddelde' lag.

Concluderend kan gesteld worden dat het gemiddeld verlies van de prognose van baanopeningen per beroepsklasse relatief laag is vergeleken met de voorspelfout bij de uitbreidingsvraag. Dit komt door de negatieve correlatie tussen voorspelfouten bij de uitbreidingsvraag en de vervangingsvraag. Als bij beide vraagcomponenten de voorgestelde verbeteringen in de prognoseaanpak worden doorgevoerd zal de voorspelkwaliteit van de baanopeningen verder kunnen verbeteren.

Tabel 4.21. Typeringen van de baanopeningen per beroepsklasse en de realisaties (relatief)

\begin{tabular}{lcccccr}
\hline Realisatie & erg laag & laag & $\begin{array}{l}\text { prognose } \\
\text { gemiddeld }\end{array}$ & hoog & erg hoog & totaal \\
\hline Erg laag & 4 & 2 & 1 & 2 & 0 & 9 \\
Laag & 2 & 8 & 3 & 6 & 4 & 23 \\
Gemiddeld & 2 & 5 & 8 & 3 & 0 & 18 \\
Hoog & 4 & 3 & 3 & 2 & 0 & 12 \\
Erg hoog & 2 & 3 & 3 & 5 & 4 & 17 \\
Totaal & 14 & 21 & 18 & 18 & 8 & 79 \\
\hline
\end{tabular}




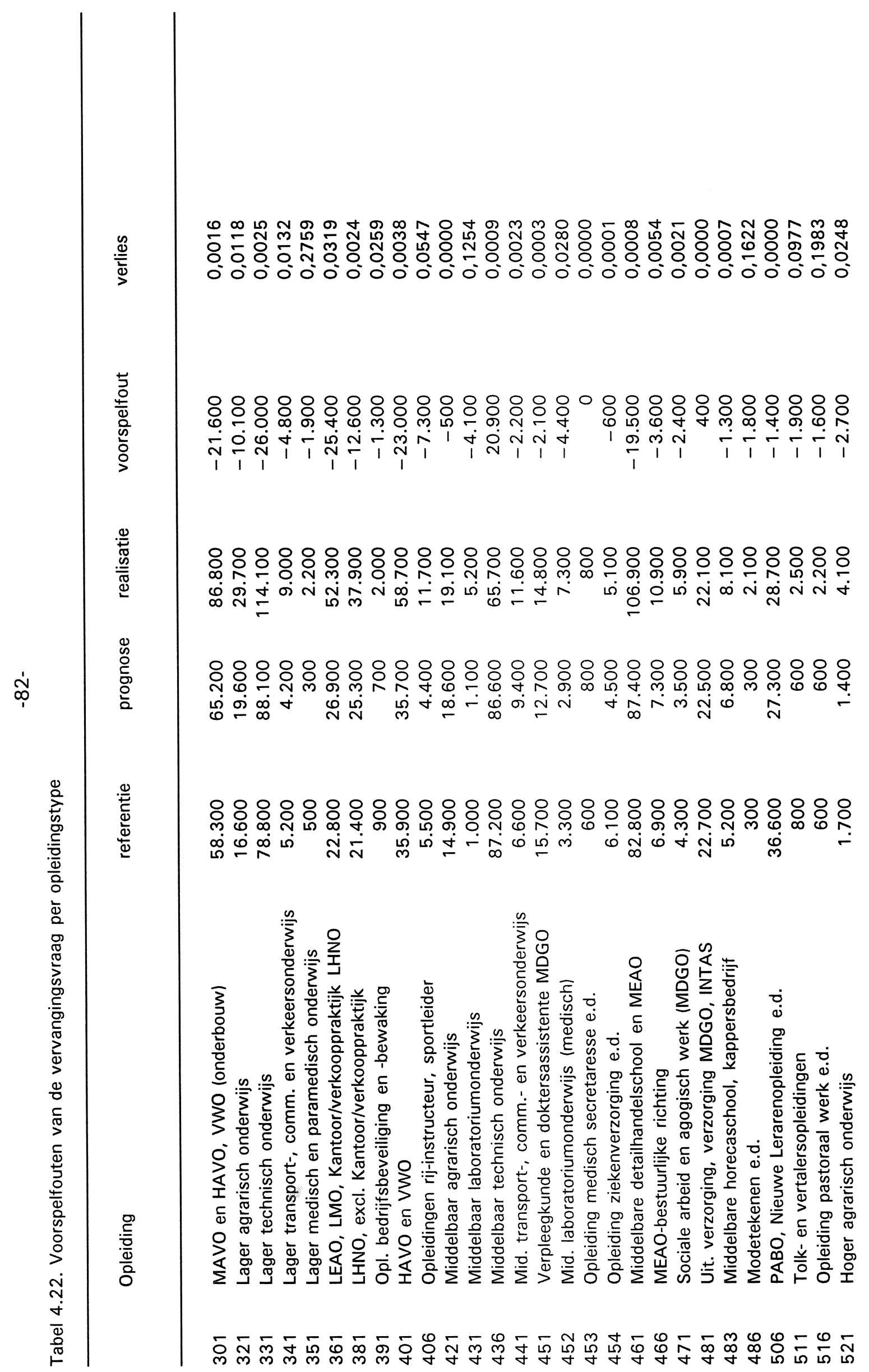




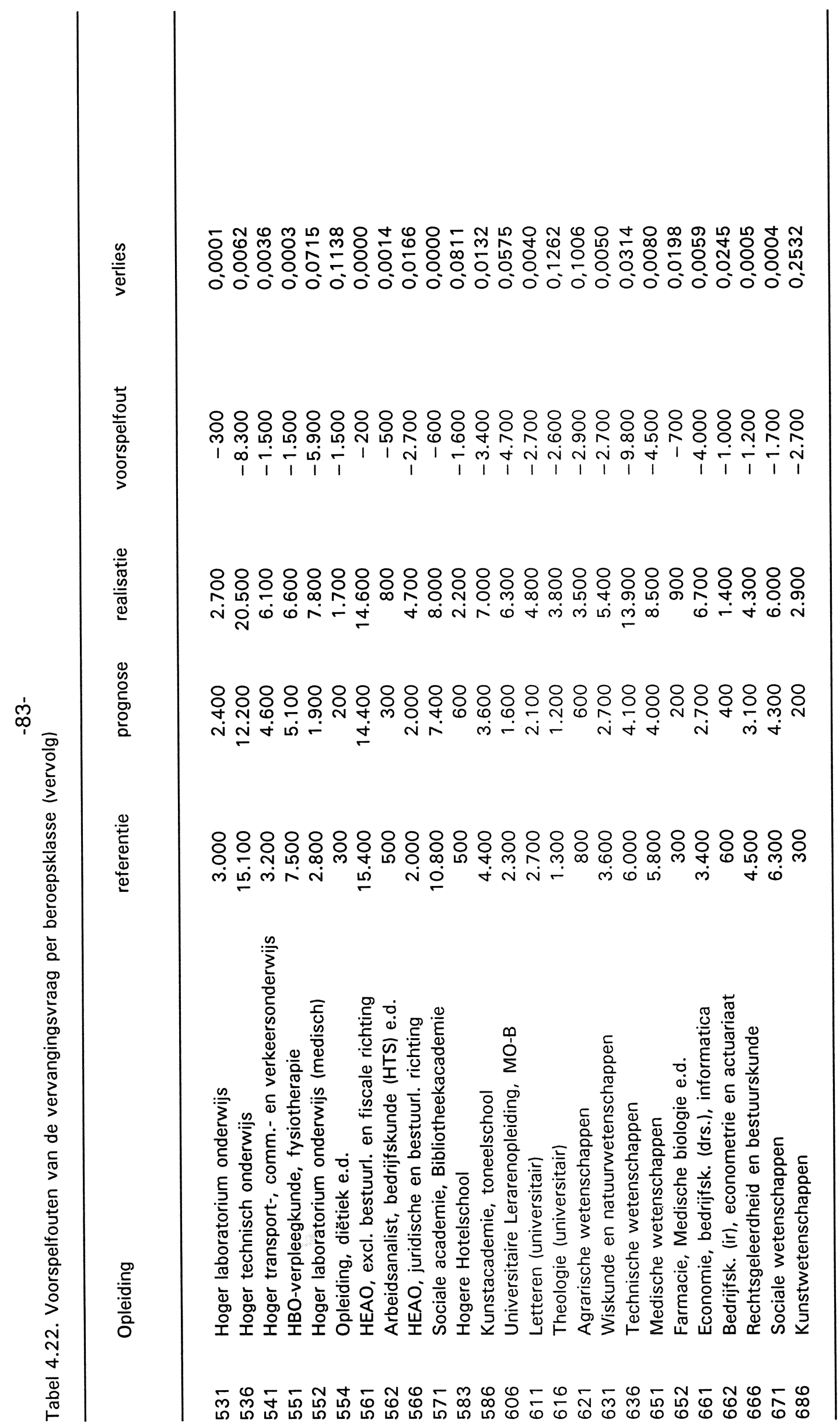




\subsection{Vervangingsvraag per opleidingstype}

Bij de vervangingsvraag per opleidingstype zijn, zoals reeds in paragraaf 2.7 werd beschreven, de prognoses simpelweg gebaseerd op het aantal werkzame personen van 55 jaar en ouder, omdat de leeftijdsstructuurdata zoals die gebruikt zijn voor de vervangingsvraag per beroepsklasse toentertijd niet beschikbaar waren. Net als bij de beroepsklassen is hierbij overigens een prognose gemaakt van wat thans als uitstroom wordt gekwalificeerd. Ook de plaatsen die na vertrek van werkenden niet opnieuw werden opgevuld zijn derhalve meegeteld in de definitie.

Uit tabel 4.22 blijkt dat de gevolgde leeftijdsaanpak een sterke onderschatting van de uitstroom heeft opgeleverd. Bijna alle prognoses zijn onderschattingen van de feitelijke uitstroom. Het grootste verlies wordt aangetroffen bij lager medisch en paramedisch onderwijs (SOI 351), kunstwetenschappen (SOI 686), opleiding pastoraal werk (SOI 516) en de modetekenen (SOI 486). Het gaat hierbij steeds om feitelijke uitstroomcijfers die meer dan de $100 \%$ hoger liggen dan de voorspelde uitstroomcijfers. Het feit dat dit alle vier opleidingstypen zijn waarbij een groot deel van de leerlingen uit vrouwen bestaat, suggereert dat de gehanteerde methode met name tekortschiet bij vrouwenopleidingen, hetgeen ook voor de hand ligt, omdat bij de gevolgde methodiek in het geheel geen rekening is gehouden met de uitstroom van met name vrouwen in verband met het verzorgen van de eigen kinderen. Het is derhalve belangrijk dat, zoals bij de huidige methodiek ook het geval is, onderscheid gemaakt wordt tussen mannen en vrouwen en (vooral bij de vrouwenopleidingen) ook rekening wordt gehouden met de uitstroom van jongere arbeidskrachten.

Tabel 4.23. Totaaloverzicht voorspelkwaliteit prognoses vervangingsvraag per opleidingstype

\begin{tabular}{lccc} 
Methode & gemiddeld verlies prognose & gemiddeld verlies referentie & score \\
\hline $\begin{array}{l}\text { Vervangingsvraag } \\
\quad \text { absoluut } \\
\text { relatief }\end{array}$ & 0,0021 & 0,0019 & 1,09 \\
$\begin{array}{l}\text { Uitstroom } \\
\quad \text { absoluut } \\
\text { relatief }\end{array}$ & 0,0020 & 0,0017 & 1,18 \\
$\begin{array}{l}\text { Opleidingsniveau (relatief) } \\
\quad \text { lager } \\
\text { middelbaar } \\
\text { hoger }\end{array}$ & 0,0056 & 0,0060 & 0,94 \\
$\quad$ academisch & 0,0039 & 0,0040 & 0,96 \\
\hline
\end{tabular}

In tabel 4.23 wordt een overzicht gegeven van het gemiddelde verlies van deze prognoses. Als referentieprognose dient weer een constant uitstroompercentage dat gelijk is aan het gemiddelde van de voorspelde uitstroom. Aan de scores valt af te lezen dat de prognoses inderdaad gericht waren op de uitstroom. Het gemiddeld verlies is echter, net als bij de uitstroom per bedrijfsklasse, 
lager wanneer de prognoses vergeleken worden met de vervangingsvraagcijfers. Dit impliceert wederom dat vervangingsvraag een veel stabielere grootheid is dan uitstroom. In paragraaf 2.7. werd verondersteld dat het verband tussen uitbreidingsvraag en uitstroom bij opleidingstypen waarschijnlijk minder sterk is dan bij beroepsklassen. Een vergelijking met tabel 4.14 laat zien dat bij opleidingstypen het verschil tussen de voorspelfout van de uitstroom en de vervangingsvraag kleiner is dan bij beroepsklassen. Bij opleidingstypen is de uitbreidingsvraag veel minder vaak negatief, zodat de onderlinge verschillen tussen uitstroom en vervangingsvraag kleiner zijn.

Tabel 4.23 geeft ook aan hoe het gemiddeld verlies verschilt tussen de verschillende opleidingsniveaus. Daaruit blijkt dat naarmate het opleidingsniveau hoger is, het gemiddeld verlies groter is. Dat geldt ook voor de referentieprognose, zodat bij de scores de volgorde minder eenduidig is. Kennelijk is de uitstroom veranderlijker bij de hogere opleidingsniveaus. Het verband tussen de uitbreidingsvraag en de uitstroom bij opleidingstypen voor de periode 1985-1992 is weergegeven in figuur 4.6. Zoals reeds werd aangegeven, blijken slechts weinig opleidingstypen een negatieve werkgelegenheidsgroei te hebben doorgemaakt. Hierdoor heeft het geen zin om voor de positieve en negatieve segementen een afzonderlijke regressielijn te schatten. In het positieve segment wordt een licht dalend verband gemeten dat overigens niet significant is (zie tabel 4.24). Dit verband wordt hoofdzakelijk veroorzaakt door enkele uitschieters. Sommige opleidingen zijn vrij nieuw zodat er sprake is van een grote instroom van jonge arbeidskrachten, terwijl er nog vrijwel geen uitstroom plaatsvindt. Het gesignaleerde verband wordt derhalve waarschijnlijk veroorzaakt doordat de regressie (ten onrechte) gebaseerd is op een verband tussen uitstroom en ex post uitbreidingsvraag, terwijl eigenlijk een verband met ex ante uitbreidingsvraag geschat zou moeten worden.

Figuur 4.6. Verband tussen uitbreidingsvraag en uitstroom bij opleidingstypen tussen 1985 en 1992

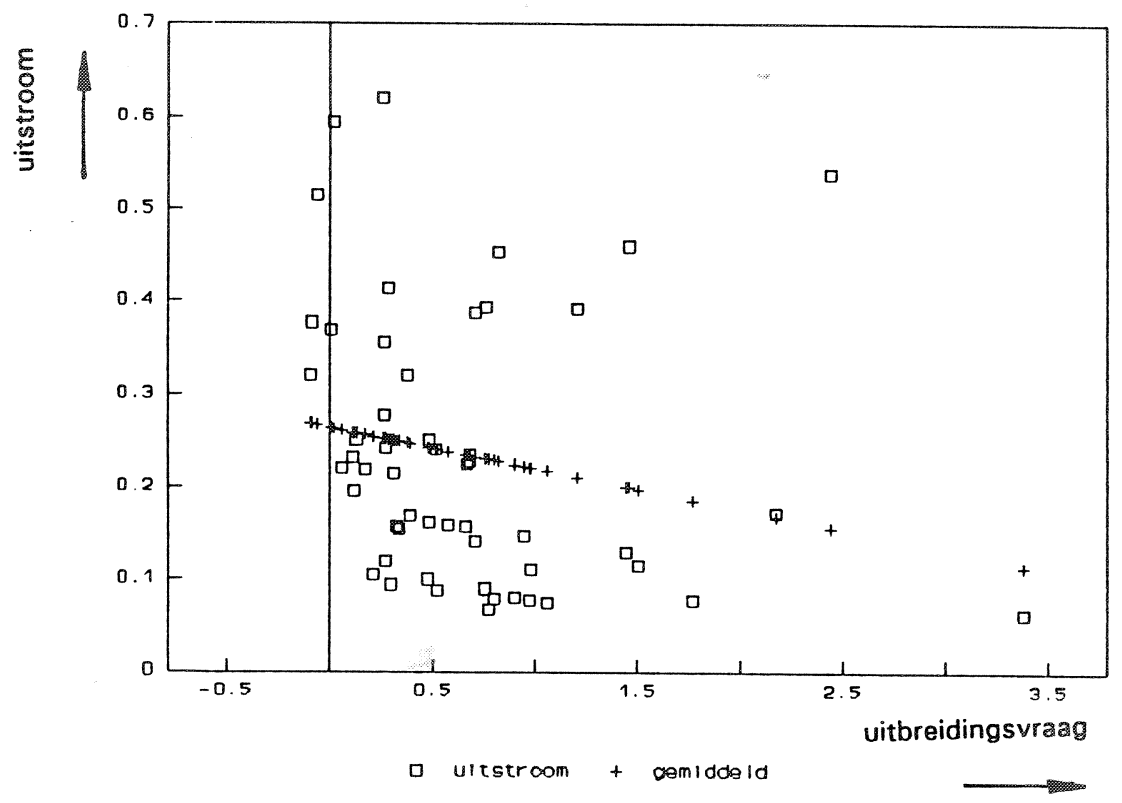


Tabel 4.24. Verband tussen uitstroompercentages en uitbreidingsvraag per opleidingstype tussen 1985 en 1992

\begin{tabular}{lrc}
\hline & parameter & t-waarde \\
\hline & & 1,83 \\
Constante & 0,26 & 1,47 \\
Uitbreidingsvraag & $-0,04$ & \\
\hline
\end{tabular}

\section{Een verklaring van de voorspelfout}

In tabel 4.25 wordt een verband gelegd tussen de standaarddeviatie van de voorspelfout en enkele verklarende variabelen. De schaalparameter is vergeleken met de andere onderdelen van het prognosemodel erg laag. Dit betekent dat grotere opleidingen relatief goed voorspeld zijn. In tegenstelling tot de relatie die geconstateerd werd bij de vervangingsvraag per beroepsklasse blijken de risico-indicatoren hier geen significante invloed te hebben op de uitstroom per opleidingstype. Dit bevestigt nogmaals de gedachte dat bij beroepsklassen invloeden van de uitbreidingsvraag zorgdragen voor mobiliteit tussen beroepen en daarmee voor fluctuaties in de uitstroom, maar dat bij opleidingstypen dit effect van uitbreidingsvraag op vervangingsvraag nauwelijks aanwezig is.

Tabel 4.25. Een verklaring van de standaarddeviatie van de voorspelfouten van de uitstroom per opleidingstype

\begin{tabular}{lcr} 
Variabele & parameter & t-waard \\
\hline & & 7,06 \\
schaal & 0,48 & 3,86 \\
constante & 2,80 & 0,80 \\
uitwijkmogelijkheden beroep & 0,45 & 0,76 \\
uitwijkmogelijkheden branche & 0,18 &
\end{tabular}

De overschatting van verandering

Tabel 4.26 geeft een overzicht van het schattingsresultaat van de test naar de mate van onderschatting van de afwijkingen. De parameter is negatief zodat er sprake lijkt te zijn van een lichte overschatting van afwijkingen. In tegenstelling tot de overschatting van afwijkingen bij vervangingsvraagprognose per beroepsklasse is dit effect echter niet significant. De methode om op basis van het aantal personen boven de 55 de uitstroom te schatten is wellicht niet beter dan de methode die gehanteerd werd bij de vervangingsvraag van beroepsklassen, maar is wel minder gevoelig voor meetfouten en bevat daardoor minder ruis die leidt tot overschatting van veranderingen. Door de meetfouten expliciet in de analyse te betrekken moet echter de voor beroepsklassen gehanteerde methode te verbeteren zijn en biedt deze techniek ook goede 
perspectieven voor de vervangingsvraagprognose per opleidingstype.

Tabel 4.26. Overschatting van afwijkingen

onderschattingscoëfficiënt $\quad t$-waarde

$\begin{array}{lll}\text { Totaal } & -0,11 & 0,42\end{array}$

\section{Kwalitatieve typeringen}

Tabel 4.27. Typeringen van de vervangingsvraag per opleidingstype en de realisatie hiervan (relatief)

\begin{tabular}{lcccccr}
\hline Realisatie & erg laag & laag & $\begin{array}{l}\text { prognose } \\
\text { gemiddeld }\end{array}$ & hoog & erg hoog & totaal \\
\hline Erg laag & 0 & 4 & 0 & 0 & 0 & 4 \\
Laag & 0 & 10 & 0 & 2 & 0 & 12 \\
Gemiddeld & 0 & 4 & 2 & 1 & 0 & 7 \\
Hoog & 0 & 5 & 2 & 2 & 0 & 9 \\
Erg hoog & 1 & 17 & 3 & 0 & 0 & 21 \\
Totaal & 1 & 40 & 7 & 5 & 0 & 53 \\
\hline
\end{tabular}

Bij de kwalitatieve typeringen van de vervangingsvraag per opleidingstype is dezelfde indeling gebruikt als bij de typering van de vervangingsvraag van beroepsklassen. Omdat de vervangingsvraag van opleidingstypen door het ontbreken van de baan-baan-mobiliteitscomponent gemiddeld lager is dan die van beroepsklassen, valt een groot aantal typeringen in de categorie 'laag'. Bij 14 opleidingstypen (26\%) is er sprake van een exact juiste typering. Bij 11 opleidingstypen wijkt de gegeven typering slechts éen categorie af van de realisatie. Al met al is bij $47 \%$ van alle opleidingstypen sprake van een redelijk juiste typering. Opvallend is dat er bij 23 als laag of erg laag getypeerde vervangingsvraagprognoses uiteindelijk sprake blijkt te zijn geweest van een hoge of erg hoge vervangingsvraag. Dit is $43 \%$ van alle prognoses. Dit komt hoofdzakelijk door het grote aantal lage typeringen. Slechts één erg laag voorspelde vervaningsvraag werd uiteindelijk erg hoog. Dat is het opleidingstype farmacie, medische biologie e.d. (SOI 652). Omgekeerd is er bij slechts twee opleidingstypen waarbij de vervangingsvraag hoog werden ingeschat uiteindelijk slechts een lage vervangingsvraag opgetreden. Uit de tabel kan afgeleid worden dat de gehanteerde methodiek veel te weinig in staat was om verschillen in de uitstroom adequaat te voorspellen.

Bijlage IV geeft een overzicht van de typeringen en de realisaties hiervan per opleidingstype. Hierin komt tot uitdrukking dat de grotere opleidingstypen relatief goed voorspeld zijn. Tabel 4.28, waarin de gemiddelde trefkansen zijn opgenomen, laat zien dat deze gemiddelde trefkans, die in deze tabel 
gewogen is met de omvang van de opleidingstypen, veel groter blijkt te zijn dan het aantal exact juiste typeringen in tabel 4.27. Bij symmetrische intervallen zou de gemiddelde trefkans $54 \%$ zijn geweest. Door het hanteren van de kwalitatieve typeringen waarbij de prognose op een willekeurige plaats in het interval terecht komt daalt deze kans tot $44 \%$. Het niet hanteren van symmetrische intervallen verlaagt de trefkans derhalve met $10 \%$-punt. Bij de feitelijke intervalgrenzen wordt dit percentage niet hoger omdat er slechts én opleidingstype in een extreme typering, in dit geval 'erg laag', viel.

Table 4.28. De gemiddelde trefkans bij verschillende soorten intervallen voor de typering van de vervangingsvraag per opleidingstype

Intervalkeuze

gemiddelde trefkans

$\%$

Symmetrisch $\quad 54$

Willekeurige positie binnen begrensd interval $\quad 44$

Feitelijk gehanteerd interval $\quad 44$

$\begin{array}{ll}\text { Resultaat } & 50\end{array}$

\section{Conclusies}

Concluderend kan gesteld worden dat het gebruik van het aantal werkzame personen van 55 jaar en ouder als prognose van de uitstroom, de verschillen tussen opleidingstypen onvoldoende kan verklaren. De methode die thans gebruikt wordt (Willems en De Grip, 1990) geeft waarschijnlijk een beter beeld van deze verschillen, temeer daar daarbij rekening wordt gehouden met de tussentijdse uittrede van vrouwen. Hierbij moet echter wel meer expliciet rekening worden gehouden met de meetfouten die in deze prognoses voorkomen. Omdat de vervangingsvraag per opleidingstype geen grote variatie vertoont zijn de typeringen, zeker bij weging naar de werkgelegenheid per opleidingstype, zeer behoorlijk. Het lijkt, gezien de mogelijke verbeteringen van de methodiek, dan ook niet noodzakelijk de intervallen van de typeringen qua breedte aan te passen.

\subsection{Het aanbod}

Zoals in paragraaf 2.8 werd aangegeven is het vanwege de gehanteerde methode en vanwege een gebrek aan adequate gegevens over de gerealiseerde arbeidsmarktinstroom naar opleidingstype, niet mogelijk een empirische evaluatie te maken van de aanbodprognoses van het informatiesysteem onderwijs-arbeidsmarkt. Om deze reden zal de evaluatie van de aanbodprognoses in deze paragraaf zich beperken tot een empirische evaluatie van de Skill-prognoses van aantallen gediplomeerden per opleidingstype in het reguliere onderwijs. Overigens is dit de belangrijkste bron voor de aanbodprognoses. 
$-89-$

Tabel 4.29. Voorspelfouten bij Skill-prognoses van het aantal gediplomeerden

\begin{tabular}{|c|c|c|c|c|c|c|}
\hline \multicolumn{2}{|c|}{ Opleiding } & \multirow{2}{*}{$\begin{array}{c}\text { SAB } \\
527.800\end{array}$} & \multirow{2}{*}{$\begin{array}{l}\text { prognose } \\
\text { '85-'92 } \\
453.200\end{array}$} & \multirow{2}{*}{$\begin{array}{c}\text { realisatie } \\
\text { '85-'92 } \\
440.600\end{array}$} & \multirow{2}{*}{$\begin{array}{c}\text { verschil } \\
12.600\end{array}$} & \multirow{2}{*}{$\begin{array}{c}\text { verlies } \\
0,0008\end{array}$} \\
\hline 1 & MAVO & & & & & \\
\hline 2 & HAVO & 295.800 & 268.300 & 270.900 & 2.600 & 0,0001 \\
\hline 3 & vwo & 231.700 & 234.900 & 229.500 & 5.400 & 0,0006 \\
\hline 4 & LTS & 306.600 & 231.900 & 252.700 & -20.800 & 0,0068 \\
\hline 5 & ITO & 51.100 & 43.000 & 42.100 & 900 & 0,0005 \\
\hline 6 & LNO & 4.200 & 3.300 & 3.100 & 200 & 0,0042 \\
\hline 7 & LAS & 50.400 & 38.500 & 39.100 & -600 & 0,0002 \\
\hline 8 & LAO & 9.800 & 10.100 & 10.000 & 100 & 0,0001 \\
\hline 9 & LHNO & 160.300 & 119.500 & 121.700 & -2.200 & 0,0003 \\
\hline 10 & IHNO & 34.300 & 32.300 & 29.800 & 2.500 & 0,0070 \\
\hline 11 & LMO & 18.200 & 18.500 & 16.200 & 2.300 & 0,0202 \\
\hline 12 & LEAO & 74.900 & 63.300 & 64.700 & 1.400 & 0,0005 \\
\hline 13 & MTS & 66.500 & 67.900 & 69.000 & 1.100 & 0,0003 \\
\hline 14 & Overige MTO & 9.800 & 7.600 & 11.100 & -3.500 & 0,0994 \\
\hline 15 & MLabO & 7.700 & 10.000 & 8.800 & 1.200 & 0,0186 \\
\hline 16 & MNO & 6.300 & 5.400 & 5.300 & 100 & 0,0004 \\
\hline 17 & MAO & 35.000 & 33.400 & 340.000 & -600 & 0,0003 \\
\hline 18 & MDGO & 110.600 & 155.000 & 120.400 & 34.600 & 0,0826 \\
\hline 19 & MDO & 23.100 & 35.000 & 35.200 & -200 & 0,0000 \\
\hline 20 & Overige MMO & 5.600 & 7.600 & 7.800 & -200 & 0,0007 \\
\hline 21 & MEAO & 69.300 & 90.600 & 84.700 & 5.900 & 0,0049 \\
\hline 23 & HTS & 63.400 & 41.500 & 36.300 & 5.200 & 0,0205 \\
\hline 24 & HLabO & 7.000 & 6.900 & 7.200 & -300 & 0,0017 \\
\hline 25 & HNO & 9.800 & 9.700 & 10.300 & -600 & 0,0034 \\
\hline 26 & HAO & 7.700 & 11.300 & 9.600 & 1.700 & 0,0314 \\
\hline 27 & HEO & 28.000 & 39.600 & 42.000 & -2.400 & 0,0033 \\
\hline 28 & HGZO & 28.000 & 33.300 & 28.700 & 4.600 & 0,0257 \\
\hline 29 & HSAO & 37.100 & 36.000 & 23.200 & 12.800 & 0,3044 \\
\hline 30 & HKO & 15.400 & 19.800 & 16.600 & 3.200 & 0,0372 \\
\hline 31 & PABO & 16.100 & 15.900 & 13.500 & 2.400 & 0,0316 \\
\hline 32 & Lerarenopleiding & 21.000 & 19.800 & 17.100 & 2.700 & 0,0249 \\
\hline 33 & WO letteren & 18.900 & 17.600 & 25.600 & -8.000 & 0,0977 \\
\hline 34 & WO wis-en natuurkunde & 13.300 & 15.800 & 13.700 & 2.100 & 0,0235 \\
\hline 35 & WO rechten & 20.300 & 27.600 & 24.200 & 3.400 & 0,0197 \\
\hline 36 & WO economie & 9.100 & 16.600 & 14.600 & 2.000 & 0,0188 \\
\hline 37 & WO sociale wetenschappen & 24.500 & 32.900 & 29.200 & 3.700 & 0,0161 \\
\hline 38 & WO medisch & 17.500 & 15.900 & 13.800 & 2.100 & 0,0232 \\
\hline 39 & WO technisch & 17.500 & 28.100 & 21.200 & 6.900 & 0,1059 \\
\hline 40 & WO landbouw & 4.200 & 7.100 & 5.800 & 1.300 & 0,0502 \\
\hline
\end{tabular}

Tabel 4.29 geeft een overzicht van de prognoses van Skill en de realisaties hiervan ${ }^{23}$. Als

23. Bij de evaluatie is gebruik gemaakt van de realisaties zoals die zijn weergegeven in de Referentieraming 1992 (O\&W, 1992). De classificatie van de Referentieraming komt echter niet geheel overen met de classificatie die in SKILL werd gebruikt. Daarom hebben enkele aanpassingen plaatsgevonden. In de 
referentieprognose (SAB) is gekozen voor de uitstroom in het schooljaar ' $85 /$ ' 86 vermenigvuldigd met 7 (het aantal prognosejaren). De tabel laat zien dat over het algemeen de uitstroom uit het onderwijs kleiner was dan in Skill was voorspeld ${ }^{24}$. Relatief de grootste fout werd gemaakt bij het Hoger Sociaal Agogisch Onderwijs, waar de gerealiseerde uitstroom 36\% achterbleef bij de prognose. Ook bij WO-technisch, overige MTO en MDGO bleven de realisaties sterk achter bij de prognoses. Bij WO-letteren bleken $45 \%$ meer studenten uit te stromen dan geraamd.

Tabel 4.30. Totaal-overzicht voorspelkwaliteit Skill-prognoses van het aantal gediplomeerden

Methode gem. verlies prognose gem. verlies SAB $\quad$ score

$\begin{array}{llll}\text { absoluut } & 0,0142 & 0,0646 & 0,22 \\ \text { relatief } & 0,0122 & 0,0142 & 0,86\end{array}$

In tabel 4.30 wordt een totaal overzicht gegeven van de voorspelfout bij de uitstroomprognoses van Skill. Net als bij de bedrijfstakprognoses van het CPB betreft het hier overigens slechts prognoses voor een deel van de periode '85-'92. Tot 1989 is er immers gebruik gemaakt van gerealiseerde data. In absolute cijfers gemeten is de score van de Skill-prognoses zeer goed, maar dit resultaat wordt voornamelijk veroorzaakt door de sterke terugloop van de uitstroom, waardoor de Same-As-Before-prognose een zeer slecht resultaat had. Bij de relatieve score, waarbij gecorrigeerd is voor deze algehele overschatting, is het resultaat minder goed. De Skill-prognoses reduceren de voorspelfout in vergelijking met $S A B$ tot $86 \%$. Mede gezien het feit dat de uitstroom in de prognoseperiode reeds aanwezig was op de betreffende scholen op het moment dat de prognoses werden opgesteld, valt dit resulaat enigszins tegen. Als echter het gemiddeld verlies van deze prognoses vergeleken wordt met de resultaten bij andere onderdelen van het prognosesysteem, dan zijn de voorspelfouten echter toch klein te noemen. Afgezien van de algehele afname van de uitstroom uit het onderwijs is er kennelijk niet zoveel verandering in het uitstroompatroon. Absoluut gezien zijn de voorspelfouten klein, zodat het aanbod waarschijnlijk een betrouwbare component van het arbeidsmarktperspectief is, maar vergeleken met een SABmethodiek wordt er weinig winst geboekt.

\section{Een verklaring van de voorspelfout}

In tabel 4.31 zijn de resultaten weergegeven van een verklaring van de voorspelfout van de Skillprognoses. Naast de constante bevat deze verklaring alleen een schaalparameter. Deze schaalparameter is weer enigszins lager dan 1, wat impliceert dat de grotere opleidingen relatief

Referentieraming zijn het MDO en het overige MMO samengevoegd tot het MMO. De totale instroom van het MMO '88-'92 is daarom volgens de verhoudingen in '85-'87 over deze twee richtingen verdeeld. Op een zelfde wijze is het HTNO in de Referentieraming weer opgesplitst in HTS, HLO en MNO. Het INTAS uit de Referentieraming is toegevoegd aan het MDGO.

24. Overigens betreft deze SKILL-prognoses slecht een termijn van 4 jaar. 
beter voorspeld zijn.

Tabel 4.31. Een verklaring van de voorspelfouten van de Skill-prognoses van het aantal gediplomeerden

\begin{tabular}{lrc}
\hline Variabele & parameter & t-waarde \\
\hline \multirow{3}{*}{ schaal } & 0,87 & 5,38 \\
constante & $-0,56$ & 0,34 \\
& & \\
\hline
\end{tabular}

\section{Overschatting van veranderingen}

Ook bij de Skill-prognoses is gekeken in hoeverre er sprake is van over- of onderschatting van veranderingen. De resultaten hiervan staan in tabel 4.32. Zowel absoluut als relatief gezien blijken de Skill-prognoses de feitelijke veranderingen aantallen gediplomeerden significant te overschatten. Deze overschatting van veranderingen stemt overeen met de bevindingen dat de prognoses van Skill een zekere instabiliteit vertonen. De gehanteerde werkwijze waarbij de meest recente waarnemingen als restricties aan het model worden opgelegd maakt dat de methode zeer gevoelig is voor uitschieters in deze laatste observaties. Hierdoor bevatten de prognoses kennelijk meer fluctuaties dan op grond van de gegevens verwacht zou mogen worden.

Tabel 4.32. Overschatting van veranderingen bij de SKILL-prognoses van het aantal gediplomeerden

overschattings- $\quad t$-waarde
coëfficiënt

$\begin{array}{lll}\text { absoluut } & -0,17 & 2,72 \\ \text { relatief } & -0,22 & 3,57\end{array}$

\section{Conclusies}

Samenvattend kan gesteld worden dat de voorspelfout bij het aanbod, vergeleken met andere onderdelen van het informatiesysteem betrekkelijk klein zijn. Dit wordt echter hoofdzakelijk veroorzaakt door de geringe mate van veranderingen in de samenstelling van het aanbod van schoolverlaters in het reguliere initiële onderwijs. De veranderingen worden hoofdzakelijk veroorzaakt door een algehele terugval van de uitstroom uit het onderwijs. Ondanks de korte voorspelperiode en ondanks het feit dat de voorspelde uitstroom in deze periode zich al op school bevindt op het moment dat de prognose werd opgesteld, is de voorspelfout van Skill niet veel kleiner dan de Same-As-Before-prognose. Ook bevat de Skill-prognose een overschatting van verandering, wat impliceert dat er elementen in de prognose zijn opgenomen die geen voorspellende waarde hebben. 


\subsection{De confrontatie van vraag en aanbod}

De vraag naar nieuwkomers per opleidingstype werd bij de hier geëvalueerde prognoses, zoals gezegd, bepaald door de baanopeningen, dat wil zeggen de som van de uitbreidingsvraag en de vervangingsvraag, terwijl het aanbod werd bepaald door het aantal schoolverlaters per opleidingstype dat de arbeidsmarkt betreedt. Van beide afzonderlijke componenten baanopeningen en aantallen schoolverlaters - kan echter geen directe empirische evaluatie van de gemaakte prognoses plaatsvinden. Bij het aanbod wordt dit probleem, zoals beschreven in paragraaf 4.7, veroorzaakt doordat er geen feitelijke schoolverlaterscijfers beschikbaar zijn op het niveau van de gehanteerde opleidingsclassificatie, waarbij rekening wordt gehouden met de gevolgde nietreguliere opleidingen.

Voor de empirische evaluatie van het aantal voorspelde baanopeningen is er, zoals in paragraaf 2.6 reeds werd aangegeven, echter sprake van een fundamenteler probleem. Dit wordt veroorzaakt door het onderscheid tussen de ex ante en ex post vraag per opleidingstype. In tegenstelling tot de vraag per beroepsklasse moet er op het niveau van opleidingstypen rekening mee worden gehouden dat de vraag zoals die zich feitelijk manifesteert in sterke mate bepaald wordt door aanbodfactoren. Omdat de prognoses van het aantal baanopeningen juist ten doel hebben de vraag te voorspellen, voordat aanpassingen van de vraag aan het aanbod hebben plaatgevonden, is het niet terecht om de feitelijk waargenomen vraagcijfers te vergelijken met de prognoses. Dit probleem manifesteert zich met name bij de uitbreidingsvraag. Theoretisch gezien zou de frictie tussen vraag en aanbod van nieuwkomers ook invloed kunnen hebben op de uitstroom van werkenden, maar praktisch lijkt de veronderstelling dat de uitstroom hoogstens wordt bepaald door de ex ante vraag, en niet door het aanbod, een gerechtvaardige aanname.

Dit rapport bevat dus geen empirische evaluatie van de prognoses van de uitbreidingsvraag of het aantal baanopeningen per opleidingstype. Een dergelijke evaluatie zou alleen zin hebben als naast de ex ante vraagprognoses ook de te verwachten aanpassingsprocessen - die aangeven hoeveel nieuwkomers uiteindelijk werk zullen vinden - expliciet zouden zijn gemodelleerd. In feite komen dergelijke ex post vraagprognoses, in combinatie met de aanbodprognoses, dan neer op een voorspelling van de werkloosheidcijfers per opleidingstype.

Hoewel het onmogelijk is om vraag- en aanbodprognoses per opleidingstype afzonderlijk te evalueren, zullen vraag en aanbod gezamelijk echter wel invloed hebben op de werkgelegenheid per opleidingstype. De feitelijk gerealiseerde vraag zal namelijk gedeeltelijk vraag- en gedeeltelijk aanbodbepaald zijn. In deze paragraaf zal daarom worden bekeken, alvorens in paragraaf 4.9 de AMI als indicator van de discrepantie tussen vraag en aanbod op de arbeidsmarkt te evalueren, in hoeverre vraag- en aanbodprognoses gezamenlijk in staat zijn de ex post baanopeningen te voorspellen. Dit gebeurt in navolging van Freeman (1980) door de feitelijke werkgelegenheid per opleidingstype te schatten als een gewogen gemiddelde van de vraag- en aanbodprognoses. Deze methode, die geen rekening houdt met de onderlinge interacties tussen opleidingstypen, werd door Freeman gebruikt voor de confrontatie van vraag en aanbod per beroepsklasse. Hierbij constateerde hij dat de werkgelegenheid per beroepsklasse voornamelijk werd bepaald door vraagfactoren. Deze 
uitkomst ondersteunt de aanname van het prognosemodel dat hier geëvalueerd wordt, dat op beroepsklassenniveau de invloed van aanbodfactoren op de ex post vraag gering is.

Tabel 4.33 bevat de resultaten van een vergelijkbare regressieanalyse voor de ex post baanopeningen per opleidingstype op basis van de prognoses van het informatiesysteem. Deze gerealiseerde baanopeningen zijn gedefinieerd als de som van de ex post werkgelegenheidstoename en de gerealiseerde uitstroom van werkenden. Bij de schatting worden deze baanopeningen, uitgedrukt als fractie van de totale werkgelegenheid, verklaard uit de prognoses voor het aantal baanopeningen en de voorspelde instroom. Daarbij is de restrictie opgelegd dat de som van de vraag- en de aanbodinvloed op de werkgelegenheid 1 is. Omdat de feitelijke werkgelegenheidsontwikkeling in totaliteit groter was dan voorspeld (mede vanwege de veranderende vraagstelling) is in de regressie een constante term opgenomen die corrigeert voor deze onderschatting. De schattingsresultaten in tabel 4.33 hebben daardoor betrekking op de relatieve voorspelkwaliteit.

Tabel 4.33. Vraag- en aanbodinvloeden op de ex post baanopeningen tussen 1985 en 1992

\begin{tabular}{lrc}
\hline & parameter & t-waarde \\
\hline Constante & 24,76 & 5,29 \\
Vraagprognose & 0,32 & 2,58 \\
Aanbodprognose & 0,68 & 5,57 \\
Score $\left(=1-\boldsymbol{R}^{\mathbf{2}}\right)$ & 0,88 & \\
\hline
\end{tabular}

De tabel laat zien dat de aanbodinvloed groter is dan de vraaginvloed op de werkgelegenheid per opleidingstype. Het is dus inderdaad belangrijk om een onderscheid te maken tussen de ex ante en ex post vraag per opleidingstype. Beide invloeden zijn significant, zodat de werkgelegenheid kennelijk ook niet volledig aanbod-bepaald is. Bij opleidingstypen met een ex ante aanbodoverschot zal derhalve een groter deel geen werk vinden of niet op de arbeidsmarkt participeren, dan bij de opleidingstypen waar sprake is van een aanbodtekort.

De resultaten in tabel 4.33 moeten overigens met grote voorzichtigheid worden bekeken. De resultaten worden immers niet louter bepaald door de vraag- en aanbodinvloeden, maar ook door de kwaliteit van de vraag- en de aanbodprognose. Als de vraag of het aanbod slecht voorspeld zijn - dat wil zeggen als de prognoses onnodige ruis bevatten - zal ook de invloed van de desbetreffende factor op de werkgelegenheid in de regressie lager uitvallen. Verder dient men zich te realiseren dat in de hier geëvalueerde vraagprognoses ook een aanbodelement verwerkt is. Ook dit kan de resulaten van tabel 4.33 hebben beïnvloed.

Uit de schattingsresultaten blijkt dat de vraag- en aanbodprognoses gezamenlijk redelijk in staat zijn de werkgelegenheidsontwikkeling te voorspellen. Gezien de onzekerheid in de afzonderlijke 
$-94-$

prognoses en gezien het feit dat de relatie tussen werkgelegenheidsontwikkeling en ex ante vraag en aanbod in de praktijk complexer zal zijn dan in de hier geanalyseerde regressie werd verondersteld, is dit resultaat bevredigend te noemen. Een onderzoek naar het feitelijke verband tussen de discrepantie tussen vraag en aanbod en de werkgelegenheidsontwikkeling zou een waardevolle uitbreiding van het informatiesysteem kunnen betekenen. Hiervoor zou echter een verbijzondering naar de verschillende opleidingstypen moeten plaatsvinden, omdat niet verwacht kan worden dat de werkgelegenheidseffecten altijd op dezelfde wijze tot stand zullen komen.

\subsection{De arbeidsmarktindicator AMI}

De functie van de prognoses van de ex ante vraag is niet, zoals bevestigd wordt door de resultaten in de vorige paragraaf, om de feitelijke werkgelegenheidsontwikkelingen te voorspellen. De prognoses van het aantal baanopeningen dienen om - in relatie met de aanbodprognoses - een indicatie te geven van de verwachte fricties op de arbeidsmarkt. Deze fricties zullen tot aanpassingen leiden die de marktpositie van personen met een opleiding in een overschotsituatie zullen verslechteren en de situatie van personen in een tekortsituatie zullen verbeteren.

Dit verwacht toekomstig arbeidsmarktperspectief komt in het informatiesysteem tot uiting in de AMI, het quotiënt van aanbod en vraag voor nieuwkomers op de arbeidsmarkt, waarbij een hoge waarde van de AMI duidt op een slecht perspectief, terwijl een lage waarde duidt op een goed perspectief. Om te kunnen komen tot een evaluatie van de prognoses van het toekostig arbeidsmarktperspectief moet dus onderzocht worden of er inderdaad een relatie bestaat tussen de $A M I$ en de (verandering van) de arbeidsmarktpositie van opleidingstypen.

Voor deze evaluatie zijn derhalve indicatoren noodzakelijk die een beeld geven van de arbeidsmarktpositie van opleidingen. Vanwege een tekort aan relevante informatie is een adequate evaluatie echter niet mogelijk. Er is op het moment onvoldoende informatie beschikbaar over de arbeidsmarktpositie van opleidingen in zowel 1985 als 1992. In de toekomst kan voor dit doel wellicht gebruik gemaakt worden van de schoolverlatersenquêtes, HBO-monitor en RUBS, maar doordat deze onderzoeken naar de arbeidsmarktpositie van schoolverlaters pas recentelijk gestart zijn, kunnen ze voor de huidige evaluatie nog niet gebruikt worden ${ }^{25}$. Verder zijn momenteel ook geen actuele gegevens bekend voor de werkloosheid per opleidingstype.

Om toch een indruk te krijgen van de voorspellende waarde van de arbeidsmarktindicator zijn op basis van de EBB-data een tweetal indicatoren geformuleerd die een verandering van de arbeidsmarktpositie aan het licht kunnen brengen, en worden werkloosheidscijfers geconstrueerd die op basis op de wel beschikbare informatiebronnen de werkloosheid per opleidingstype zo goed mogelijk benaderen. De reconstructie is gebaseerd op actuele informatie van het CPB over de totale omvang van de werkloosheid, waarbij voor de verdere verdeling op het juiste aggregatieniveau de laatst beschikbare cijfers van de registratie van de Arbeidsvoorzieningsorganisatie uit 1991 zijn

25. Het ontbreken van gegevens voor het WO betekent overigens een verdere inperking van de mogelijkheden om de schoolverlatersenquêtes te gebruiken voor evaluatiedoeleinden. 
gehanteerd. De twee indicatoren die naast de werkloosheid de veranderingen in de arbeidsmarktpositie moeten aanduiden zijn de verandering in het functieniveau van de banen waarin men terecht komt met een bepaalde opleiding en de verandering in de beroepenspreiding per opleidingstype ${ }^{26}$. Verwacht kan worden dat een ongunstige arbeidsmarktsituatie ertoe zal leiden dat men werkzaam is in banen op een gemiddeld lager functieniveau. Ook zal in dat geval de spreiding van de werkgelegenheid groter zijn geworden, omdat men immers vanwege de ongunstige arbeidsmarktsituaite moet uitwijken naar andere beroepsklassen. Dit betekent dat er bij de functieniveauvariabele een negatieve en bij de spreidingsvariabele een positieve samenhang met de AMI verwacht kan worden. De werkloosheid zal uiteraard positief moeten samenhangen met de hoogte van de AMI. Het valt overigens te verwachten dat met name de verandering van het functieniveau en de verandering van de spreiding een grote samenhang zullen vertonen.

Tabel 4.34 geeft een overzicht van de samenhang tussen de AMI en de drie indicatoren van de arbeidsmarktsituatie ${ }^{27}$. Het blijkt dat met name de verwachte relatie tussen de voorspelde arbeidsmarktsituatie en de werkloosheid aanwezig is. De AMI lijkt hiermee een redelijke goede voorspeller van werkloosheidscijfers te zijn geweest. Uit de tabel blijkt inderdaad dat de werkloosheid niet de enige uitingsvorm van de arbeidsmarktdiscrepanties is. Indien het voorspelde aanbodoverschot in zijn geheel werkloos zou zijn geworden, zou de bijbehorende parameter iets groter dan 1 moeten zijn. De relatie tussen de werkloosheid en de AMI is overigens slechts significant op een betrouwbaarheidsniveau van $85 \%$. De overige twee indicatoren zijn echter niet significant. De relatie met veranderingen van het functieniveau waarop mensen werkzaam zijn heeft het verwachte teken, maar de relatie met de AMI is slechts zwak. Bij de verandering van de spreiding wordt zelfs een relatie met de $\mathrm{AMI}$ geconstateerd die tegengesteld is aan de verwachting hiervan. De regressie-uitkomsten worden beïnvloed door de sterke samenhang tussen beide aanpassingsindicatoren. Als alleen de spreidingsindicator wordt gebruikt om de AMI te verklaren, heeft het geschatte effect wel de verwachte richting. De grootste tekortkoming bij deze analyse lijkt te zijn dat er geen goede indicatoren beschikbaar zijn over de (veranderingen van de) arbeidsmarktpositie van personen met een bepaalde opleidingsachtergrond. Zoals reeds werd opgemerkt, kunnen in de toekomst gegevens uit de schoolverlatersenquêtes verandering brengen in deze situatie.

In tabel 4.34 is ook een regressievergelijking opgenomen waarin de AMI die destijds gehanteerd is vervangen is door een indicator waarbij, zoals thans bij de berekening van de ITA gebruikelijk is, zowel in de teller als in de noemer ook de totale werkgelegenheid in het betreffende opleidingstype is opgenomen. De resultaten verbeteren aanzienlijk door deze wijziging in de definitie. De score verbetert met $16 \%$, van 0,91 tot 0,76 en de parameter van de werkloosheid wordt nu duidelijk significant. Kennelijk heeft het toevoegen van de totale werkgelegenheid aan beide kanten van de

26. De verandering in opleidingsniveau van de werkgelegenheid wordt gemeten conform Borghans en Heijke (1993); de verandering van de beroepenspreiding vindt plaats op basis van de Gini-Hirschman-indicator.

27. Omdat de AMI een voorspeller is van de genoemde indicatoren zou eigenlijk in de regressie de $A M I$ als verklarende variabele moeten worden opgenomen. In dat geval kunnen de drie indicatoren echter niet simultaan in een eenvoudige regressie worden opgenomen. Voor een groot aantal opleidingen waren overigens geen werkloosheidsdata beschikbaar. Deze opleidingen zijn uit de regressie gelaten. Verder is bij de opleidingen waarbij de AMI groter is dan 10, deze in de regressie op 10 gesteld. 
spanningsindicator inderdaad de verwachte stabiliserende werking, waardoor de voorspellende waarde van de indicator toeneemt.

In Bijlage $\mathrm{V}$ is een overzicht opgenomen van de destijds berekende AMI's per opleidingstype. Verder bevat deze tabel de schatting van de realisatie van de AMI op grond van de regressie in tabel 4.34 en de voorspelde en gerealiseerde kwalitatieve typeringen. Tabel 4.35 bevat een vergelijking tussen de prognose en de realisatie van de kwalitatieve typeringen van het arbeidsmarktperspectief per opleidingstype. Bij deze tabellen dient men zich echter wel te realiseren dat niet alleen de prognoses, maar ook de geschatte realisaties onzekerheid bevatten. Discrepanties tussen prognose en realisatie kunnen derhalve ontstaan zijn door zowel voorspelfouten als door een onnauwkeurige bepaling van de gerealiseerde perspectieven.

Tabel 4.34. De relatie tussen de voorspelde AMI en de werkloosheid in 1992 en de indicatoren voor de verandering in de arbeidsmarktpositie tussen 1985 en 1992

\begin{tabular}{lrrrr} 
Variabele & parameter & \multicolumn{1}{l}{$\begin{array}{l}\text { AMI } \\
\text { t-warde }\end{array}$} & parameter & \multicolumn{1}{c}{$\begin{array}{c}\text { 'ITA' } \\
\text { t-waarde }\end{array}$} \\
\hline Constante & 1,31 & 1,46 & 0,92 & 12,13 \\
Werkloosheid '92 & 0,40 & 1,49 & 0,06 & 3,03 \\
Verandering functieniveau & $-4,83$ & 0,56 & $-0,17$ & 0,24 \\
Verandering spreiding & $-0,18$ & 0,04 & $-0,02$ & 0,06 \\
& & & 0,76 & \\
Score $\left(=1-R^{2}\right.$ ) & 0,91 & & & \\
\end{tabular}

Tabel 4.35. Typeringen van de arbeidsmarktindicator AMI en de geschatte realisaties volgens tabel 4.34

\begin{tabular}{|c|c|c|c|c|c|c|}
\hline ROA prognose & goed & redelijk & $\begin{array}{l}\text { geschatte } \\
\text { matig }\end{array}$ & $\begin{array}{r}\text { realisatie } \\
\text { slecht }\end{array}$ & zeer slecht & totaal \\
\hline Goed & 3 & 5 & 8 & 0 & 0 & 16 \\
\hline Redelijk & 0 & 7 & 6 & 0 & 0 & 13 \\
\hline Matig & 0 & 1 & 2 & 0 & 0 & 3 \\
\hline Slecht & 0 & 1 & 2 & 1 & 0 & 4 \\
\hline Zeer slecht & 0 & 0 & 5 & 1 & 0 & 6 \\
\hline Totaal & 3 & 14 & 23 & 2 & 0 & 42 \\
\hline
\end{tabular}

Ondanks deze problemen bij het meten zijn de resultaten redelijk goed te noemen. Bij 13 van de 42 opleidingstypen komt de kwalitatieve typering precies overeen met de realisatie. Dit is $30 \%$ van alle opleidingstypen. Als hierbij worden meegerekend, de typeringen die slechts éen categorie naast de gerealiseerde typering zijn voorspeld, zijn dit 28 van de 42 opleidingstypen. $67 \%$ van de 
opleidingstypen heeft dus een redelijk goede typering van de arbeidsmarktindicator gekregen. $\mathrm{Er}$ zijn overigens opvallend weinig opleidingstypen waarbij prognose en realisatie in een tegengestelde richting wijzen. Alleen bij het zeer heterogene en ook moeilijk van de andere opleidingstypen af te bakenen opleidingstype universitaire lerarenopleiding MO-B (SOI 606) werd een slecht perspectief voorspeld, terwijl de realisatie redelijk was. Overigens werd ook al bij de voorlopige evaluatie (De Grip, Heijke en Berendsen, 1991) geconstateerd dat de prognoses per opleidingstype beter waren dan de prognoses per beroepsklasse. Kennelijk werken niet alle prognosefouten bij beroepsklassen door bij de voorspellingen van opleidingstypen en heeft ook de relatief goed voorspelbare aanbodcomponent een positieve invloed op de prognoseresultaten.

Bij de kwalitatieve typeringen van de AMI is toentertijd een indelingsschema gehanteerd dat afwijkt van de overige kwalitaitieve typeringen in het informatiesysteem:

$\begin{array}{rll}0 & <\text { AMI } & \leq 1,00 \text { goed } \\ 1,00 & <\text { AMI } & \leq 2,00 \text { redelijk } \\ 2,00 & <\text { AMI } & \leq 4,00 \text { matig } \\ 4,00 & <\text { AMI } & \leq 8,00 \text { slecht } \\ 8,00 & <\text { AMI } & \text { of } \\ 0 & \geq \text { AMI } & \end{array}$




\section{BESLUIT}

\subsection{Inleiding}

In dit rapport is een evaluatie gemaakt van de eerste prognoses die gemaakt zijn in het kader van het informatiesysteem onderwijs-arbeidsmarkt. Deze in 1989 opgestelde prognoses hadden betrekking op de arbeidsmarkt naar opleiding en beroep in 1992. Doordat deze prognosetermijn inmiddels verstreken is, was het mogelijk een terugblik op deze prognoses te maken die completer is dan de eerste evaluatie die in 1991 plaatsvond (De Grip, Heijke en Berendsen, 1991). Inmiddels hebben er echter, op grond van de ervaringen die zijn opgedaan met het opstellen van de prognoses, substantiële veranderingen plaatsgevonden in de opzet en methodiek van het informatiesysteem, waardoor de aanpak van de prognoses die hier geëvalueerd zijn niet meer overeenkomt met de huidige werkwijze. In 1989 stond het informatiesysteem nog duidelijk in de kinderschoenen. Desalniettemin is het toch zeer informatief gebleken de destijds gehanteerde opzet en prognosemethodes kritisch in beschouwing te nemen.

In de voorgaande hoofdstukken zijn de prognoses voor de arbeidsmarkt naar opleiding en beroep in 1992 geëvalueerd. Hierbij is ten eerste gekeken naar de opzet van het informatiesysteem en de bij de prognoses gehanteerde methodiek. Ten tweede heeft er een empirische evaluatie plaatsgevonden van de toentertijd opgestelde prognoses. In dit hoofdstuk worden de belangrijkste bevindingen kort op een rij gezet. Allereerst zal een overzicht worden gegeven van de belangrijkste resultaten van de empirische evaluatie. Daarna komen achtereenvolgens de opzet van het informatiesysteem en de gehanteerde prognosemethodiek aan de orde. Daarbij wordt telkens aan de hand van de bevindingen in dit rapport bekeken welke verbeteringen er de afgelopen jaren reeds hebben plaatsgevonden en welke verdere ontwikkeling van het informatiesysteem de voorspelkwaliteit en de bruikbaarheid van de arbeidsmarktinformatie in de toekomst nog verder zouden kunnen vergroten.

\subsection{De resultaten van de empirische evaluatie}

Tabel 5.1 geeft een overzicht van enkele belangrijke kencijfers uit de empirische evaluatie met betrekking tot de afzonderlijke onderdelen van het prognosemodel. Allereerst geeft het gemiddeld verlies aan hoe groot de voorspelfout van de afzonderlijke prognose-onderdelen was. Het laagste gemiddeld verlies wordt aangetroffen bij de vervangingsvraag per opleidingstype, terwijl ook het gemiddeld verlies bij de vervangingsvraag per beroepsklasse vrij laag is. Kennelijk is het mogelijk relatief trefzekere prognoses van de vervangingsvraag te maken. Ook de Skill-prognoses van de aantallen gediplomeerden in het regulier onderwijs hebben een betrekkelijk laag gemiddeld verlies. Dit cijfer is echter niet goed vergelijkbaar met de andere verliescijfers, omdat de voorspelfouten niet gerelateerd zijn aan aantallen werkzame personen, maar aan aantallen leerlingen. Uit een onderlinge vergelijking van de verschillende vraag- en aanbodprognoses blijkt dat de prognose voor de uitbreidingsvraag per beroepsklasse verreweg de geringste trefzekerheid heeft. Deze vraagcomponent is, zoals overigens ook verwacht kon worden, het moeilijkst voorspelbare onderdeel van het informatiesysteem. De prognoses van het totaal aantal baanopeningen per 
beroepsklasse - die gevormd worden door de som van de uitbreidingsvraag en de vervangingsvraag - hebben daarentegen een grotere trefzekerheid. Dit komt door de negatieve correlatie tussen de voorspelfouten bij de uitbreidingsvraag en de vervangingsvraag.

Bij de score - dat is de verhouding tussen het gemiddeld verlies van de prognose en het gemiddeld verlies van de 'Same as Before'-referentieprognose - blijkt de uitbreidingsvraag per beroepsklasse echter geen uitschieter te zijn. In verhouding met de referentieprognose functioneert de voorspelling van de uitbreidingsvraag dus niet slechter dan andere onderdelen van het prognosemodel. Op de meeste onderdelen is de voorspelscore van de puntprognoses als matig te classificeren. De waarde is doorgaans iets lager dan 100 wat impliceert dat de prognoses slechts weinig beter voorspellen dan de referentieprognose. Ondanks het lage gemiddeld verlies, blijkt de prognose van de vervangingsvraag per beroepsklasse qua score niet beter te zijn dan de andere onderdelen van het informatiesysteem. Dit komt doordat bij de vervangingsvraag ook de referentieprognoses relatief goed scoren, terwijl bijvoorbeeld bij de uitbreidingsvraag per beroepsklasse ook de Same as Before prognose een groot gemiddeld verlies heeft. Uit de analyse is gebleken dat de overstap van uitstroomprognoses naar vervangingsvraagprognoses, die inmiddels is gemaakt, een aanzienlijke verbetering van de prognoses zal betekenen. Ook bij de uitbreidingsvraag per beroepsklasse is er een duidelijk aanwijsbare reden voor de matige voorspelkwaliteit. Dat is het ontbreken van een trend bij een groot deel van de uitbreidingsvraagprognoses per beroepsklasse. De tabel laat zien dat indien de bedrijfssectorprognoses met een correcte structuurmatrix voor 1992 verdeeld zouden zijn over de beroepsgroepen, de score voor de beroepsklasseprognoses op $54 \%$ uit zou komen. Bij de beroepsklassen waarbij gebruik gemaakt is van een trendvariabele voor het opstellen van de prognoses komt de score op $47 \%$.

Bij de verklaring van de standaarddeviatie van de voorspelfout blijkt dat alle onderdelen een schaaleffect vertonen. De schaalfactor is steeds kleiner dan 1, hetgeen impliceert dat grotere beroepsklassen en opleidingstypen gemiddeld een kleinere procentuele voorspelfout hebben. Dit schaaleffect is het grootst bij de vervangingsvraag per opleidingstype. Dit onderdeel van de tabel laat zien dat er binnen de prognose-onderdelen nog variatie in de voorspelfout zit. De bedrijfssectorprognoses zijn relatief goed voorspeld bij de agrarische en industriële bedrijfssectoren en bij de vervangingsvraag wordt een duidelijke samenhang geconstateerd met de risico-indicatoren uit het informatiesysteem. Hoe groter de conjunctuurgevoeligheid en hoe kleiner de uitwijkmogelijkheden, des te groter is hier de voorspelfout. Verder blijkt de vervangingsvraag per beroepsklasse een zeer grote voorspelfout te bevatten indien er tussen de observatieperiode en de prognoseperiode een grote verandering heeft plaatsgevonden van de uitbreidingsvraag. Hieruit blijkt dat inderdaad ten onrechte is verondersteld dat de uitstroom van werkenden uit de beroepsklasse niet afhangt van de werkgelegenheidsontwikkeling op dat moment.

Het volgende onderdeel in de tabel betreft de onder- of overschatting van veranderingen. De prognoses van het CPB voor de werkgelegenheid per bedrijfssector blijken een onderschatting van veranderingen te vertonen. De werkelijke veranderingen zijn gemiddeld twee maal zo groot als door het CPB werd voorspeld. Bij de prognoses van de uitbreidingsvraag van beroepsklassen waarbij geen trendterm is opgenomen, is er sprake van een overschatting van veranderingen. Hetzelfde 
is het geval bij de vervangingsvraag per beroepsklasse. Deze overschattingen worden waarschijnlijk veroorzaakt doordat er een grote hoeveelheid ruis in de prognoses zit. Om deze problemen in de toekomst te vermijden zal, zoals reeds gebeurd is bij de uitbreidingsvraag per beroepsklasse (zie Borghans en Heijke, 1994), zorgvuldig rekening gehouden moeten worden met de invloed van meetfouten op de voorspellingen.

Ten slotte worden in de laatste kolom van de tabel de resultaten met betrekking tot de kwalitatieve typeringen weergegeven. Er wordt aangegeven hoeveel procent van de prognoses exact de juiste typering heeft gekregen, alsook hoeveel prognoses een typering hebben gekregen die vrijwel goed is, dat wil zeggen een typering die hoogstens éen klasse afwijkt van de gerealiseerde typering. Opvallend is dat met name de arbeidsmarktindicator AMI op basis waarvan de arbeidsmarktperspectieven per opleidingstype worden getypeerd, hier goede resultaten heeft. De bevindingen van de voorlopige evaluatie dat met name deze spanningsindicator goede prognoseresultaten geeft worden hiermee bevestigd. De in deze kolom samengevatte evaluatieresultaten komen overigens voort uit de voorspelkwaliteit van de prognoses als zodanig, maar worden ook beïnvloed door de wijze van typeren. Het is gebleken dat bij sommige onderdelen intervallen voor met name de typering 'gemiddeld' gehanteerd zijn die erg klein zijn vergeleken met de standaarddeviatie van de voorspelfouten. Verder zal met name bij de moeilijk voorspelbare uitbreidingsvraag per beroepsklasse overgestapt moeten worden op een globalere manier van typeren.

Bij de empirische evaluatie van de prognoses kwamen enkele belangrijke tekortkomingen van de prognosemethodiek aan het licht. De oorzaken die de grootste invloed op de prognoseresultaten hebben gehad waren, afgezien van problemen vanwege een gebrek aan data:

- het te weinig opnemen van een trend in de prognoses van de uitbreidingsvraag per beroepsklasse;

- het feit dat er geen rekening is gehouden met de relatie tussen uitbreidingsvraag en uitstroom;

- het onvoldoende rekening houden met meetfouten in de gebruikte data.

Met betrekking tot de eerste twee punten hebben er inmiddels belangrijke veranderingen plaatsgevonden. De trend wordt tegenwoordig bij alle beroepsklassen op een verantwoorde wijze in het model betrokken en ook de prognosemethode voor de vervangingsvraag is sterk verbeterd. Gezien de thans beschikbare databronnen lijkt het echter wenselijk om de prognosemethode voor de vervangingsvraag nog verder te verbeteren. Ook wordt bij de vervangingsvraag, evenals bij enkele andere onderdelen van de prognosemethodiek nog onvoldoende rekening gehouden met de invloed van de onnauwkeurigheid in de data. Alleen bij de uitbreidingsvraag per beroepsklasse heeft op dit gebied inmiddels een aanpassing plaatsgevonden die in dit opzicht bevredigend lijkt te werken.

Een belangrijke bevinding van de empirische evaluatie is dat het uiterst belangrijk is om modellen te maken die in hoge mate robuust zijn. Het is goed mogelijk om prognoses voor opleiding en beroep op een laag aggregatieniveau te maken, maar op grond van betrekkelijk kleine onzorgvuldigheden in de modellering kan een groot deel van de mogelijke voorspelkracht weer verloren gaan. Ondanks de gemaakte fouten blijken de voorspelingen toch nog redelijk te zijn. 


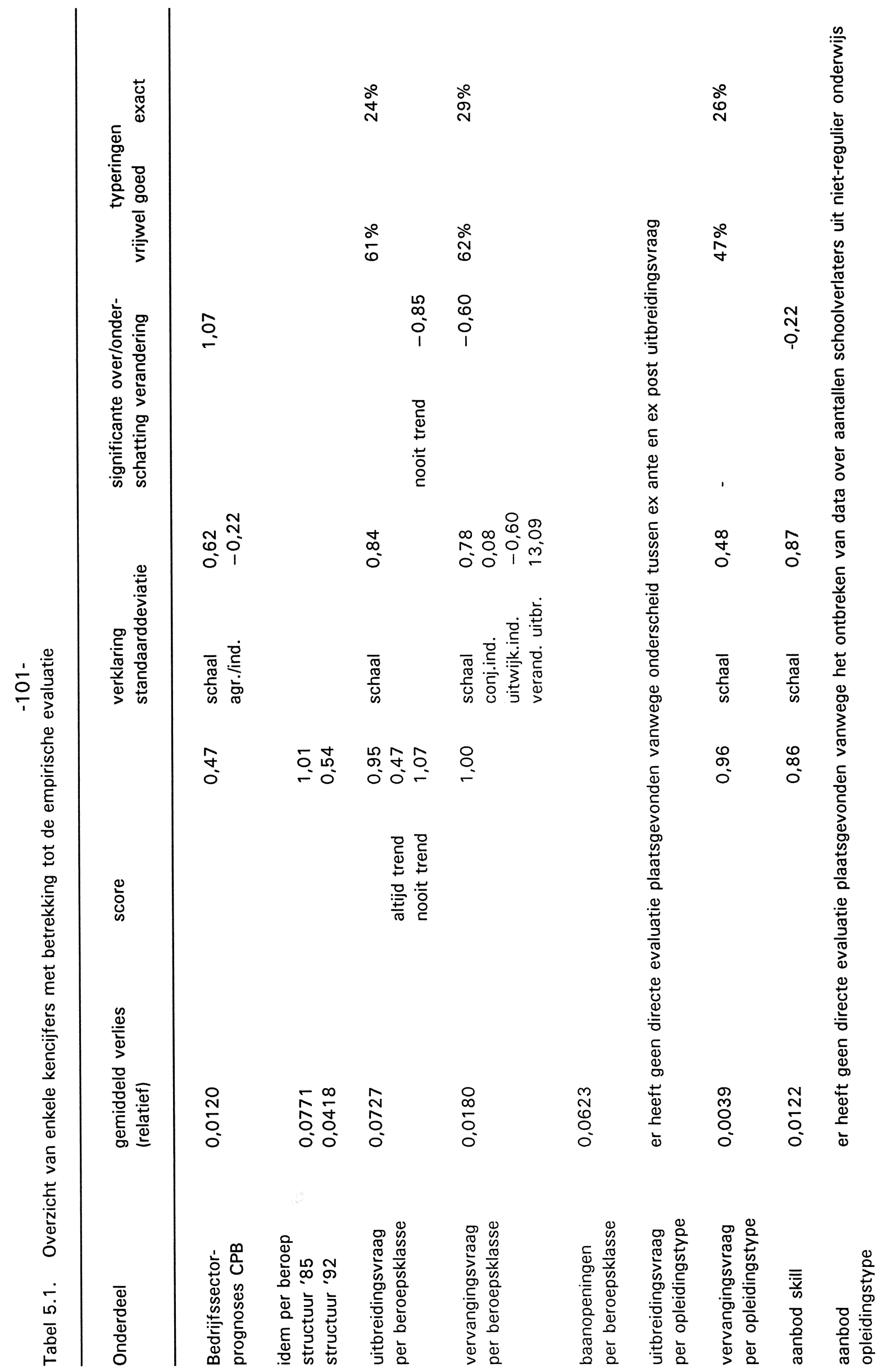




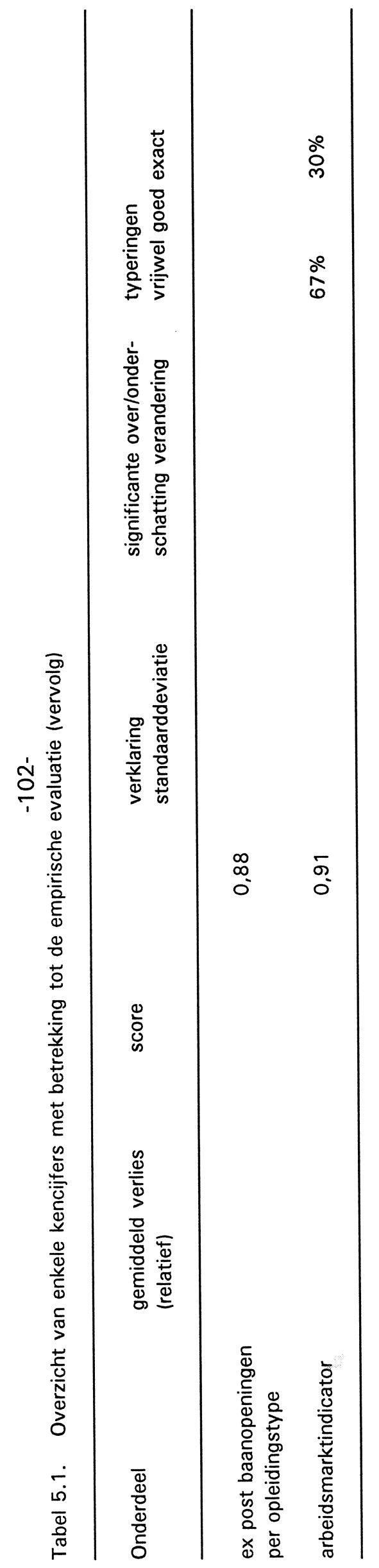




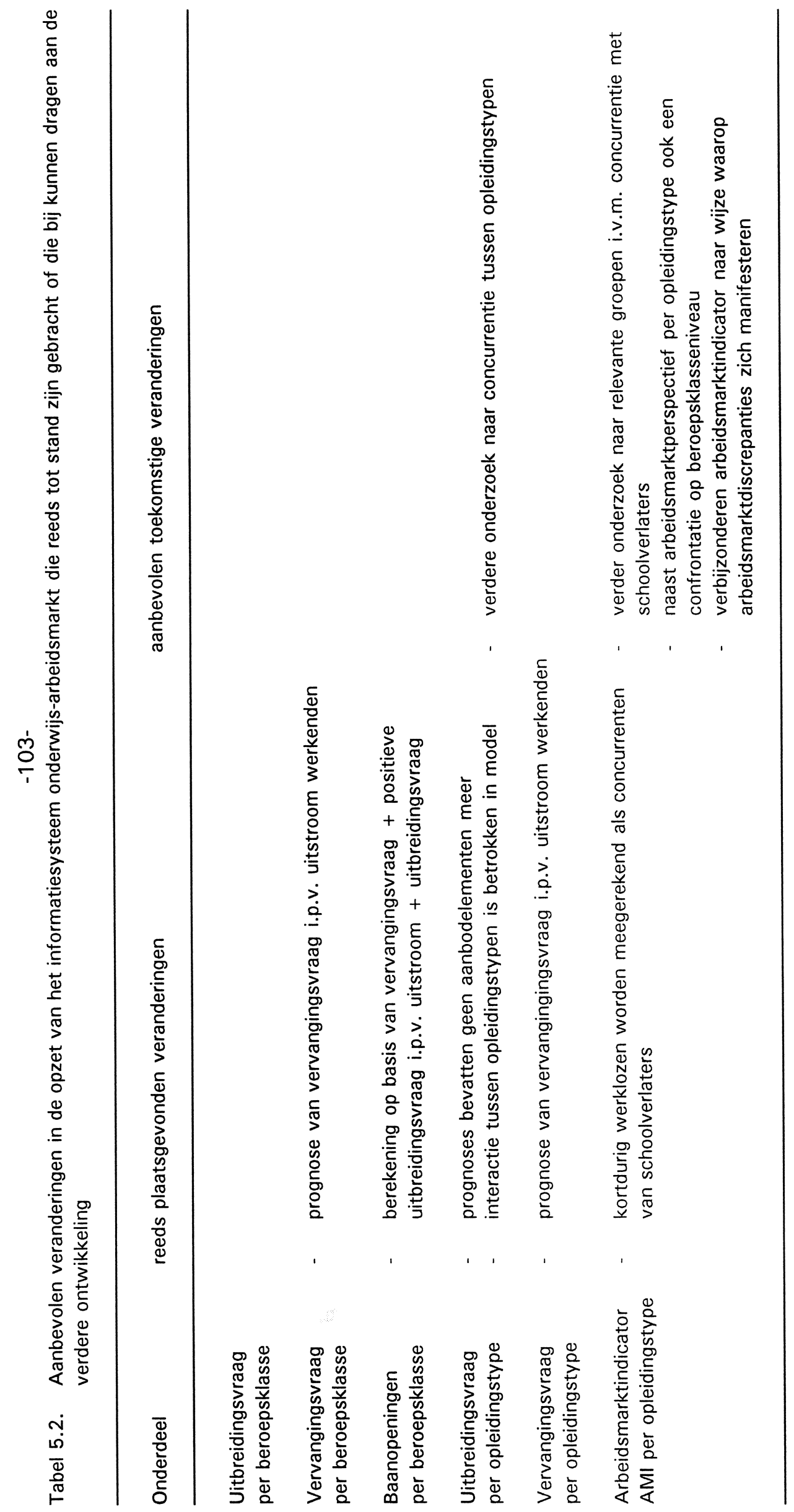




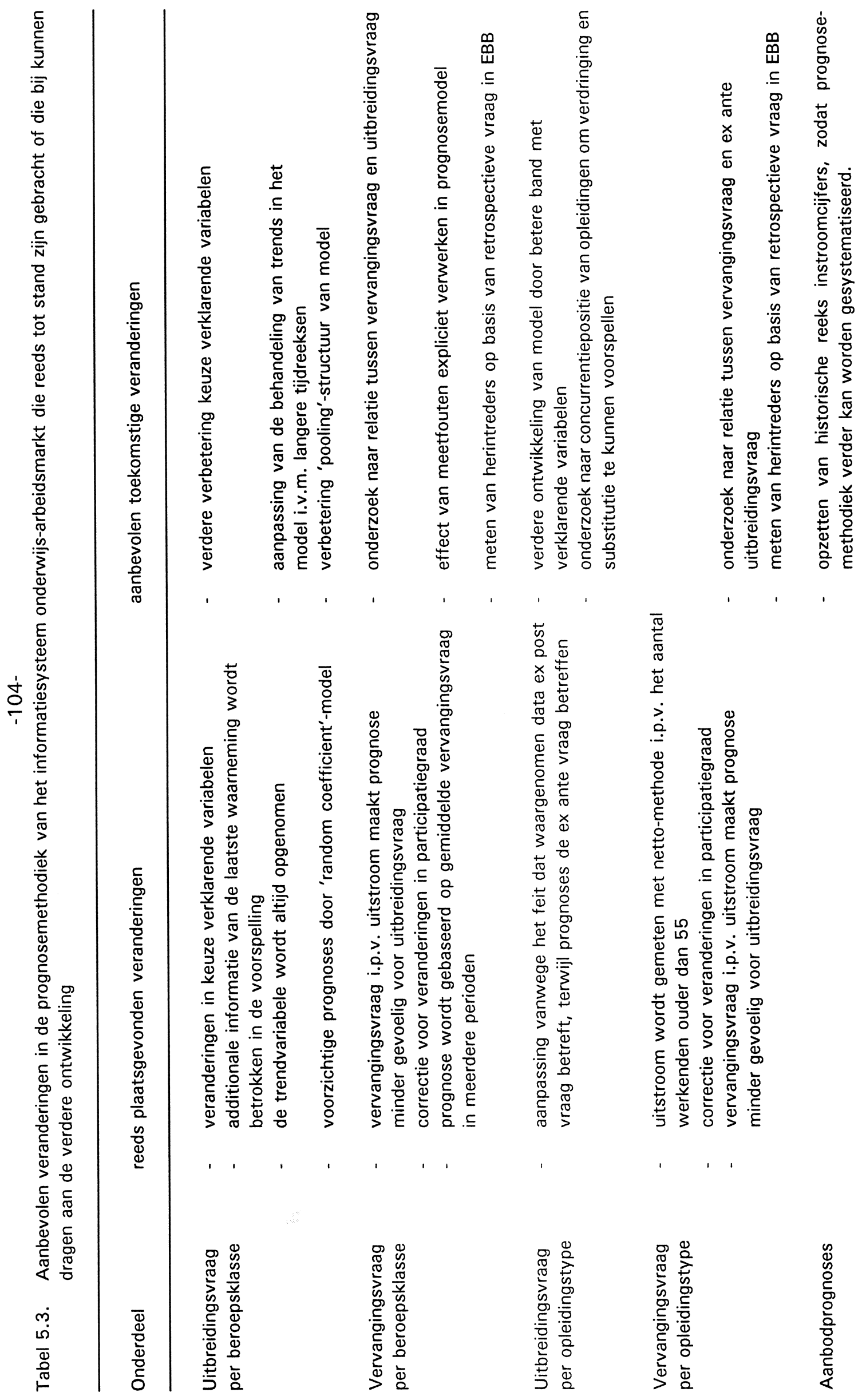




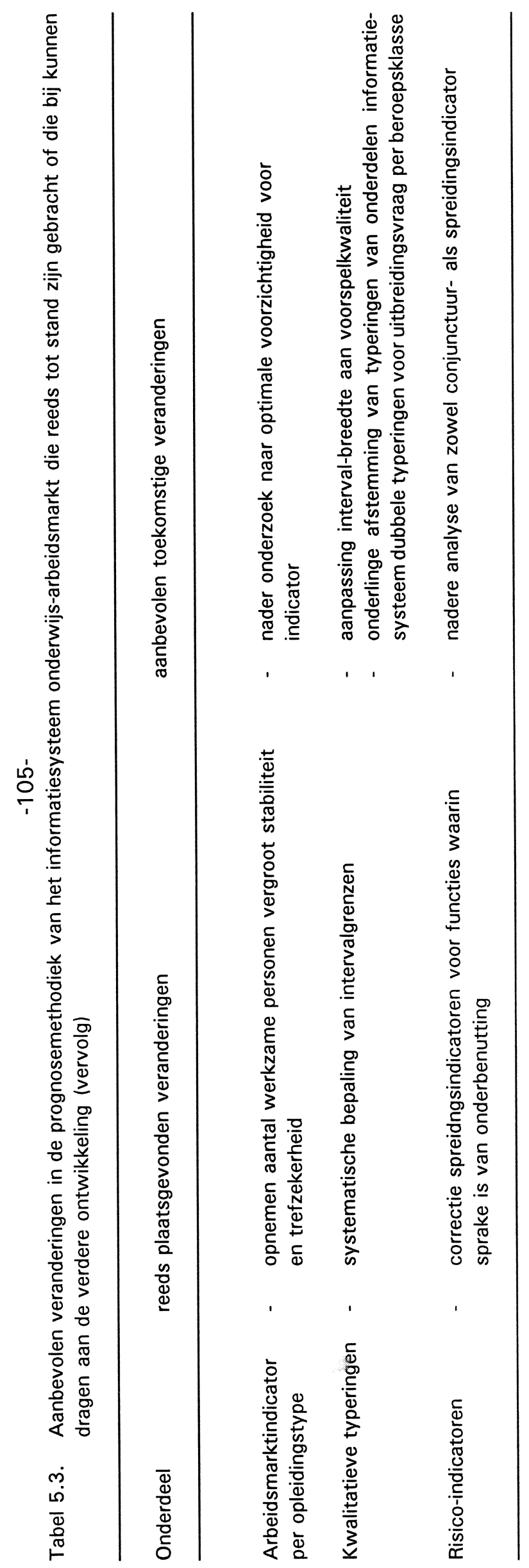


Met name de uitbreidingsvraag per beroepsklasse blijkt een moeilijk voorspelbaar element te zijn. In overeenkomst met de bevindingen in het vorige evaluatierapport zijn de resultaten per opleidingstype beter. Als hierbij de hierboven genoemde tekortkomingen in ogenschouw worden genomen, lijken de mogelijkheden om te komen tot een verdere verbetering van de resultaten aanwezig te zijn. Voor een belangrijk deel zullen dergelijke verbeteringen overigens al gerealiseerd zijn door de wijzigingen in de opzet en de methodiek van het informatiesysteem die al hebben plaatsgevonden.

\subsection{Aanbevolen veranderingen in opzet informatiesysteem en prognosemethodiek}

Zowel bij de beschouwing van de opzet van het informatiesysteem als bij de empirische evaluatie is aan het licht gekomen op welke onderdelen de opzet van het informatiesysteem en de gebruikte prognosemodellen goed functioneren en waar een aanpassing van de opzet of de methodiek is vereist. Omdat het met name van belang is een overzicht te hebben van de onderdelen van het informatiesysteem die zouden moeten worden aangepast, zijn in tabel 5.2 en tabel 5.3 per onderdeel de veranderingen opgesomd. Tabel 5.2 bevat de veranderingen met betrekking tot de opzet van het informatiesysteem, die er met name op gericht zijn de arbeidsmarktgegevens beter geschikt te maken voor het primaire doel, de informatieverschaffing voor de studie- en beroepskeuzebegeleiding. In tabel 5.3 staan de punten vermeld, waarop de prognosemethodiek verandering behoeft. In de tabellen wordt een onderscheid gemaakt tussen de veranderingen die reeds plaats hebben gevonden en de veranderingen die bij de verdere ontwikkeling van het informatiesysteem nog uitgevoerd zouden kunnen worden. In deze paragraaf zal niet op alle punten in de tabellen worden ingegaan. Een nadere toelichting op deze afzonderlijke punten kan gevonden worden in de hoofdstukken 2 en 4 van dit rapport.

De opzet van het informatiesysteem is in grote lijnen onveranderd gebleven. Deze opzet, zoals weergegeven in figuur 1.1, blijkt op zich goed te functioneren. De belangrijkste aanpassingen die hebben plaatsgevonden betroffen de vervangingsvraag en de arbeidsmarktindicator, de basis van de uiteindelijke vraag-aanbod-confrontatie per opleidingstype. De overstap van prognoses die betrekking hebben op de uitstroom van werkenden naar een systematiek gebaseerd op de vervangingsbehoefte, blijkt zowel voor de voorspelkwaliteit alsook voor de interpreteerbaarheid van de prognoses een duidelijke verbetering te zijn geweest. Bij de arbeidsmarktindicator wordt, in tegenstelling tot de prognoses voor 1992, momenteel ook de invloed van kortdurig werklozen meegewogen bij de bepaling van de toekomstige arbeidsmarktperspectieven. Voor het verder verbeteren van de interpreteerbaarheid van de prognoses ligt het voor de hand om de tamelijk abstracte spanningsindicator verder te verbijzonderen naar de wijze waarop de arbeidsmarkt zal reageren op de overschotten of tekorten aan personen met een bepaalde opleidingsachtergrond. Op grond daarvan zou bijvoorbeeld in een concreet geval het arbeidsmarktperspectief niet alleen als 'slecht' getypeerd worden, maar wordt bovendien een uitspraak gedaan over de mate waarin dit slechte perspectief zal leiden tot banen op lagere functieniveaus, lagere lonen en hogere werkloosheid (of langere zoekduren). Verder dient in dit verband ook gekeken te worden naar de onderlinge relatie tussen de arbeidsmarktperspectieven van opleidingstypen. Substitutie en verdringing als gevolg van spanningen op de arbeidsmarkt zijn immers per definitie tegelijkertijd van 
invloed op meerdere opleidingstypen. Er is overigens al een begin gemaakt met het incalculeren van verdringingsprocessen bij het voorspellen van het arbeidsmarktperspectief. Om hieraan verder gestalte te geven moet er, bijvoorbeeld op basis van de informatie uit de schoolverlatersenquêtes, nader onderzoek worden gedaan naar de concurrentiepositie van opleidingen.

Tabel 5.3 gaat in op de reeds aangebrachte en voor de toekomst aanbevolen veranderingen van de prognosemethodiek. Zonder in te gaan op alle afzonderlijke punten in deze tabel zijn er twee facetten die bij veel van deze punten een rol spelen. Uit de evaluatie blijkt dat het maken van adequate prognoses voor de arbeidsmarkt naar opleiding en beroep op een aggregatieniveau zoals dat wordt gehanteerd binnen het informatiesysteem in principe goed mogelijk is, maar dat kleine onvolkomenheden in de prognosemethodiek soms tot een drastische verslechtering van de voorspelkwaliteit kunnen leiden. Deze onvolkomenheden worden in veel gevallen veroorzaakt door de verstorende werking van meetfouten binnen de prognoses of doordat de gehanteerde prognosemethodiek niet voldoende robuust is. Ten eerste is het voor de verdere ontwikkeling van het prognosemodel dus van belang dat de prognosemodellen gebaseerd worden op stabiele verbanden. Bij de vervangingsvraag heeft een dergelijke verbetering inmiddels al plaatsgevonden, door in plaats van de sterk fluctuerende uitstroom van werkenden de veel robuustere vervangingsvraag te gebruiken als basis voor de extrapolaties. Ook de aanpassing om prognoses van de uitbreidingsvraag sterker te baseren op de laatste waarnemingen kunnen op een eenvoudige wijze de betrouwbaarheid van de voorspellingen vergroten. Ten tweede dient bij de verdere ontwikkeling voortdurend rekening gehouden te worden met de invloed van meetfouten die op het lage aggregatieniveau dat gehanteerd wordt grote invloed kunnen hebben op de betrouwbaarheid van de prognoses. Door de introductie van conservatieve elementen in de schattings- en prognosetechniek kunnen de meetfouten voor een groot deel geëlimineerd worden. Voorbeelden hiervan zijn de resultaten van het 'random coefficients'-model dat inmiddels gehanteerd wordt voor de uitbreidingsvraag per beroepsklasse en de positieve invloed op de voorspelbaarheid door de stabilisatie van de arbeidsmarktindicator ITA.

Op grond van de bevindingen van deze evaluatie kan geconcludeerd worden dat bij de verdere ontwikkeling van het informatiesysteem een aantal zaken prioriteit dient te krijgen. Dit betreft allereerst een verdere ontwikkeling van zowel de prognosemethode voor de uitbreidingsvraag als de vervangingsvraag. Daarnaast is het belangrijk om te komen tot een verdere uitwerking van de arbeidsmarktindicator. Door gebruik te maken van informatie uit de schoolverlatersenquêtes zou, zoals reeds werd opgemerkt, een indicatie gegeven kunnen worden van de aanpassingseffecten die bepaalde spanningen op de arbeidsmarkt zullen hebben. Deze uitbreiding zal de interpreteerbaarheid van de prognoses sterk verbeteren. Pas nadat deze onderdelen van de prognosemethodiek verbeterd zijn, lijkt het zinvol om over te gaan tot eventuele uitbreidingen van het informatiesysteem, bijvoorbeeld gericht op het toespitsen van de arbeidsmarktinformatie op andere gebruiksdoelen. Hierbij kan gedacht worden aan een verlenging van de prognosetermijn, maar ook aan het maken van een confrontatie tussen vraag en aanbod op het niveau van beroepsklassen, hetgeen de bruikbaarheid van het informatiesysteem voor het arbeidsvoorzieningenbeleid zou kunnen vergroten. Door dergelijke aanpassingen c.q. uitbreidingen zou het informatiesysteem, meer dan nu het geval is, ook informatie kunnen verschaffen die ondersteunend kan zijn voor de arbeidsmarktoriëntatie vanuit de optiek van de vraagkant van de arbeidsmarkt. 


\section{LITERATUUR}

Beekman, Th.B.J., R.J.P. Dekker, A. de Grip en J.A.M. Heijke (1989), Een verklaring van de opleidingenstructuur van beroepen, ROA-W-1989/3, Maastricht look verschenen als 'An Explanation of the Educational Structure of Occupations', in Labour 5-3, 1991, pp. 151-163).

Bierings, H.B.A., J.C.M. Imbens en C.A. van Bochove (1990), De definitie van de beroepsbevolking, Supplement sociaal-economische maandstatistieken, 91-2, pp. 4-21.

Bishop, H.J. en S. Carter (1991), How Accurate are Recent BLS Occupational Projections', Monthly Labour Review, oktober 1991, pp. 37-43.

BLS (1988), Projections 2000, Bulletin 2302, Washington D.C.

BLS (1992), Occupations Projections and Training Data, BLS Bulletin 2401, Washington, DC.

Borghans, L. (1991), De arbeidsmarkt en de invloed van voorspellingen, Economische Statistische Berichten, 76-3833, pp. 1113-1116.

Borghans, L. (1992), A Histo-Topographic Map of the Dutch University Studies, ROA-W-1992/5E, Maastricht.

Borghans, L. (1993), Educational Choice and Labour Market Information, proefschrift Maastricht.

Borghans, L. en J.A.M. Heijke (1993), Forecasting the Educational Structure of Occupations: A Manpower Requirement Approach with Substitution, ROA-RM-1993/2E, Maastricht.

Borghans, L. en J.A.M. Heijke (1994), Een random-coëfficiënten-model voor het voorspellen van de beroepenstructuur van bedrijfstakken, verschijnt binnenkort.

Bosworth, D.L., G.J. Evans en R.M. Lindley (1974), Mechanic Manpower Models. In: J.S. Wabe (ed) Problems in Manpower Forecasting, Westmead, pp. 61-84.

Clements, M.P. en D.H. Hendry (1993), Towards a Theory of Forecasting, Oxford.

CBS (1953), De voorziening in de behoefte aan onderwijzers bij het lager onderwijs in 1952, Utrecht.

CPB (1993), Athena; Een bedrijfstakkenmodel voor de Nederlandse economie, CPB, Den Haag.

Dekker, R.J.P. en A. de Grip, Vergelijking tussen de CBS- en de ROA-beroepenclassificatie, ROA-W1992/3, Maastricht. 
Dekker, R.J.P., A. de Grip, Th.B.J. Beekman, P.J.E. van de Loo, M.H. Wieling en E.J.T.A. Willems (1990), Rapportage I-See! 1990, ROA-R-1990/6, Maastricht.

Dekker, R.J.P., A. de Grip, H. Berendsen, M.H. Wieling en E.J.T.A. Willems (1992), Methodiek en structuur arbeidsmarktmodule I-See! 1991, ROA-W-1992/1, Maastricht.

Dekker, R.J.P., A. de Grip, L. Borghans, A.G.M. Matheeuwsen, M.H. Wieling, E.J.T.A. Willems (1993), Methodiek van het informatiesysteem onderwijs-arbeidsmarkt 1993, ROA-W-1993/3, Maastricht.

Dekker, R.J.P., A. de Grip en P.J.E. van de Loo (1990), ROA-Beroepenclassificatie 1990, ROA-W1990/9, Maastricht.

Dekker, R.J.P., A. de Grip en J.A.M. Heijke (1988), Een verklaring van de beroepenstructuur van bedrijfstakken, ROA-W-1988/2, Maastricht look verschenen als 'An Explanation of the Occupational Structure of Sectors of Industry' in Labour 4-3, 1990, pp. 3-31).

Eijgenraam, C.J.J. en E.M. Verkade (1988), BETA; Een bedrijfstakkenmodel van de Nederlandse economie, $\mathrm{CPB}$, Den Haag.

Eijs, P. van (1993), The Manpower Requirements Approach, Background and Methodology, ROARM-1993/3E, Maastricht.

Eijs, P. van, en L. Borghans (1993), Manpower Forecasting and the Aggregation Problem: $A$ Microeconomic Approach, ROA-RM-1993/6E.

Eijs, P. van (1994), Manpower Forecasting in the Western World: The Current State of the Art, ROA-RM-1994/1E, Maastricht.

Evans, G.J. en R.M. Lindley (1973), The Use of RAS and Related Models in Manpower Forecasting, Economics of Planning 13-1,2, pp. 53-73.

Freeman, R.B. (1980), An Empirical Analysis of the Fixed Coefficient 'Manpower Requirements' model 1960-1970, Journal of Human Resources 15-2, pp. 176-199.

Glebbeek, A.C. (1993), Perspectieven op loopbanen, proefschrift, Groningen.

Granger, C.W.J. en P. Newbold (1986), Forecasting Economic Time Series, Orlando.

Grip, A. de, L.F.M. Groot, J.A.M. Heijke (1987), Clustering Occupational Classes by Educational Structure, ROA-W-1987/2E, Maastricht (ook verschenen als 'Defining Occupational Groupings by Educational Structure', Environment and Planning A 1991, vol. 23, pp. 59-85). 
Grip, A. de, en J.A.M. Heijke (1991), Flexibiliteit versus produktiviteit, Onderzoek van Onderwijs, vol. 20-1, pp. 6-8.

Grip, A. de, J.A.M. Heijke en H. Berendsen (1991), Eerste evaluatie informatiesysteem onderwijsarbeidsmarkt, ROA-R-1991/1, Maastricht.

Grip, A. de, J.A.M. Heijke, J.W. van Dam, R.J.P. Dekker en M.H. Wieling (1988), Aanvulling arbeidsmarktmodule I-See project (wetenschappelijk onderwijs), ROA-R-1988/2, Maastricht.

Grip, A. de, J.A.M. Heijke en R.J.P. Dekker (1989), De arbeidsmarkt naar opleiding en beroep in 1992, ROA-R-1989/8, Maastricht.

Grip, A. de, J.A.M. Heijke, R.J.P. Dekker, Th.B.J. Beekman en H.M.M. Peeters (1989), De arbeidsmarktperspectieven van beroepsklassen en opleidingstypen in 1992: rapportage I-See!, ROAR-1989/7, Maastricht.

Grip, A. de, J.A.M. Heijke, R.J.P. Dekker en L.F.M. Groot (1987a), De arbeidsmarkt naar beroep in 1992 en de positie van academici daarbinnen, ROA-W-1987/1, Maastricht.

Grip, A. de, J.A.M. Heijke, R.J.P. Dekker, L.F.M. Groot en L.A. Vos (1987b), De arbeidsmarktperspectieven van studierichtingen in het wetenschappelijk onderwijs, Arbeidsmarktmodule I-See project, ROA-R-1987/3, Maastricht.

Grip, A. de, J.A.M. Heijke en L.A. Vos (1987), Inventariserend onderzoek arbeidsmarktmodule I-See project, ROA-R-1987/1, Maastricht.

Grip, A. de, en E.J.T.A. Willems (1992), De vervangingsvraag naar beroepsklasse tot 2000, OSA-W 96, Den Haag.

Ministerie van Onderwijs en Wetenschappen (1992), Referentieraming 1992, Zoetermeer.

OSA (1993), Vraag en aanbod in het primair onderwijs 1989-1994; Rapport over prognoses en beleidsmogelijkheden, OSA, Den Haag.

Peeters, H.M.M. (1990), An Explanation of the Occupational and Educational Structure of Employment by Means of Multinomial Logit, ROA-W-1990/4E, Maastricht.

ROA (1991), De arbeidsmarkt naar opleiding en beroep tot 1994, Prototype, ROA-R-1991/5, Maastricht.

ROA (1992a), De arbeidsmarkt naar opleiding en beroep tot 1994, ROA-R-1992/1, Maastricht.

ROA (1992b), De arbeidsmarkt naar opleiding en beroep tot 1994. Statistische Bijlage, ROA-R- 
1992/1B, Maastricht.

ROA (1993a), De arbeidsmarkt naar opleiding en beroep tot 1998, ROA-R-1993/10, Maastricht.

ROA (1993b), De arbeidsmarkt naar opleiding en beroep tot 1998. Statistische bijlage, ROA-R1993/10B, Maastricht.

Velden, R. van der, en L. Borghans (1993), Competition on the Labour Market. An Analysis of the Position of Types of Training, ROA-RM-1993/5E, Maastricht.

Wieling, M.H., A. de Grip en E.J.T.A. Willems (1990), Een systematische kwalitatieve typering van arbeidsmarktinformatie, ROA-W-1990/8, Maastricht.

Willems, E.J.T.A. en A. de Grip (1990), Vervangingsvraagprognoses naar beroep en opleiding, ROA-W-1990/7, Maastricht (ook verschenen als 'Forecasting Replacement Demand by Occupation and Education', International Journal of Forecasting 9, 1993, pp. 173-185).

Wilson, R. (1994), Modelling and Forecasting the Structure of Employment in the United Kingdom. In: H. Heijke (ed), Forecasting the Labour Market by Occupation and Education, Boston, pp. 9-35. 


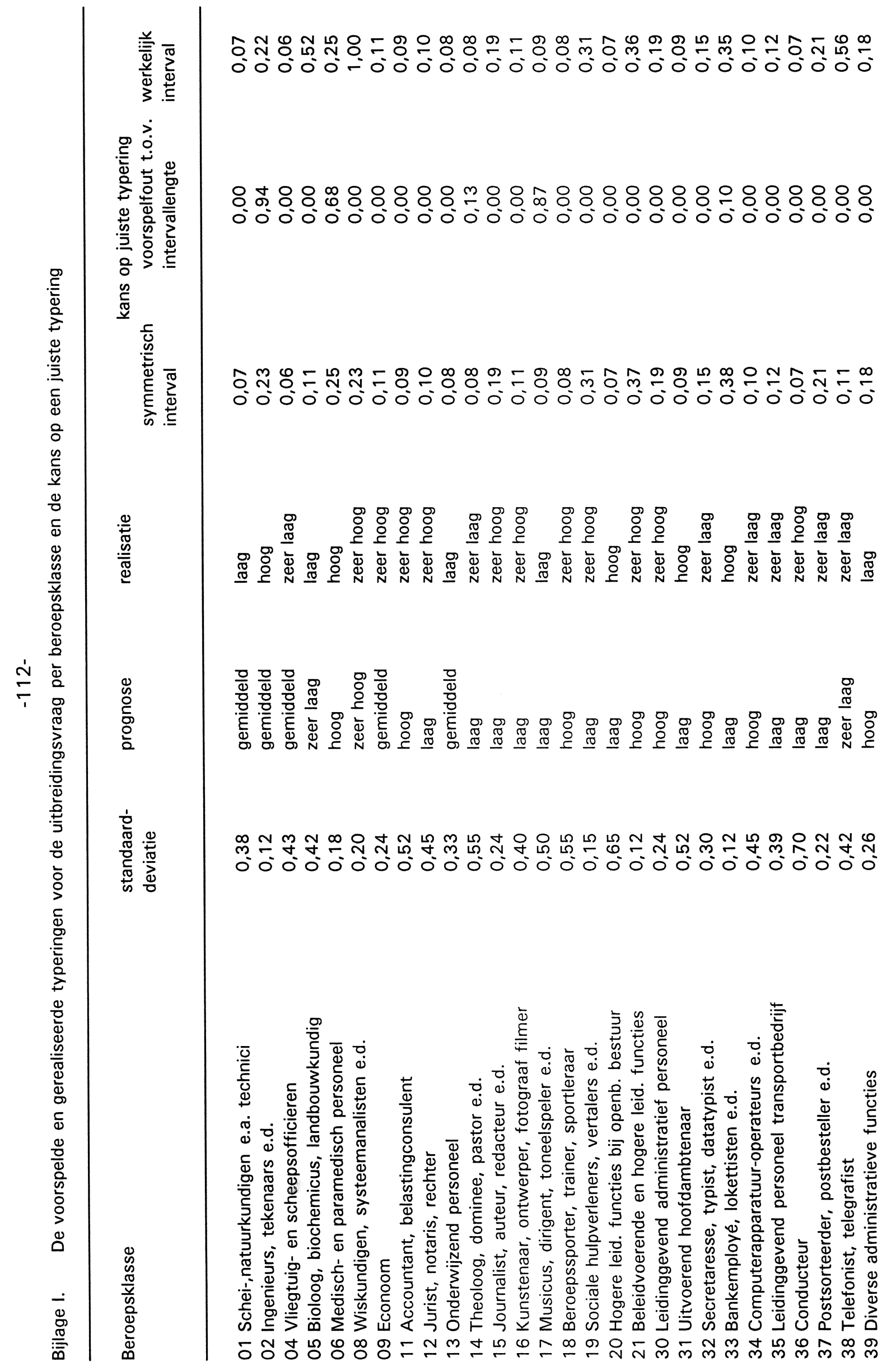




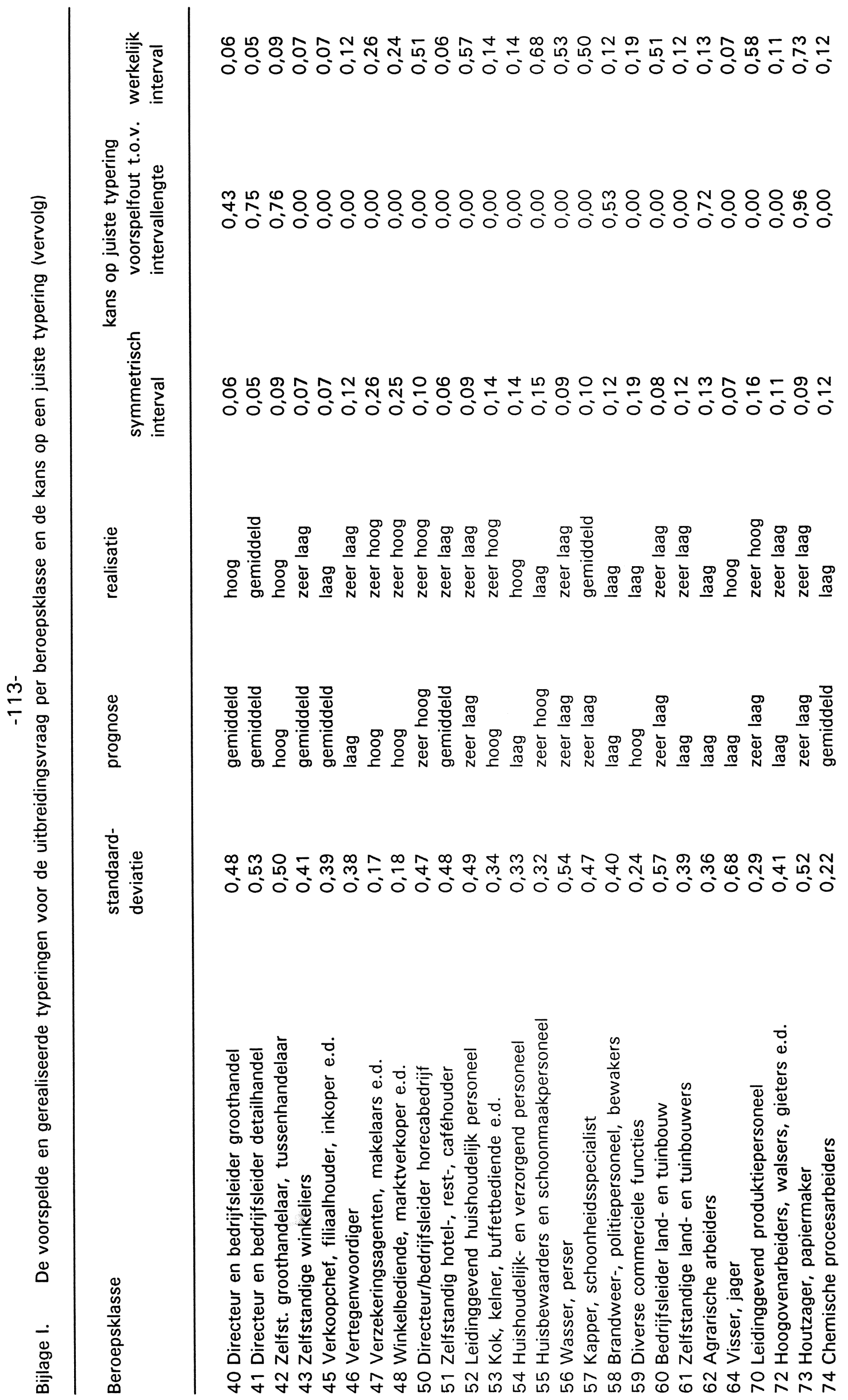




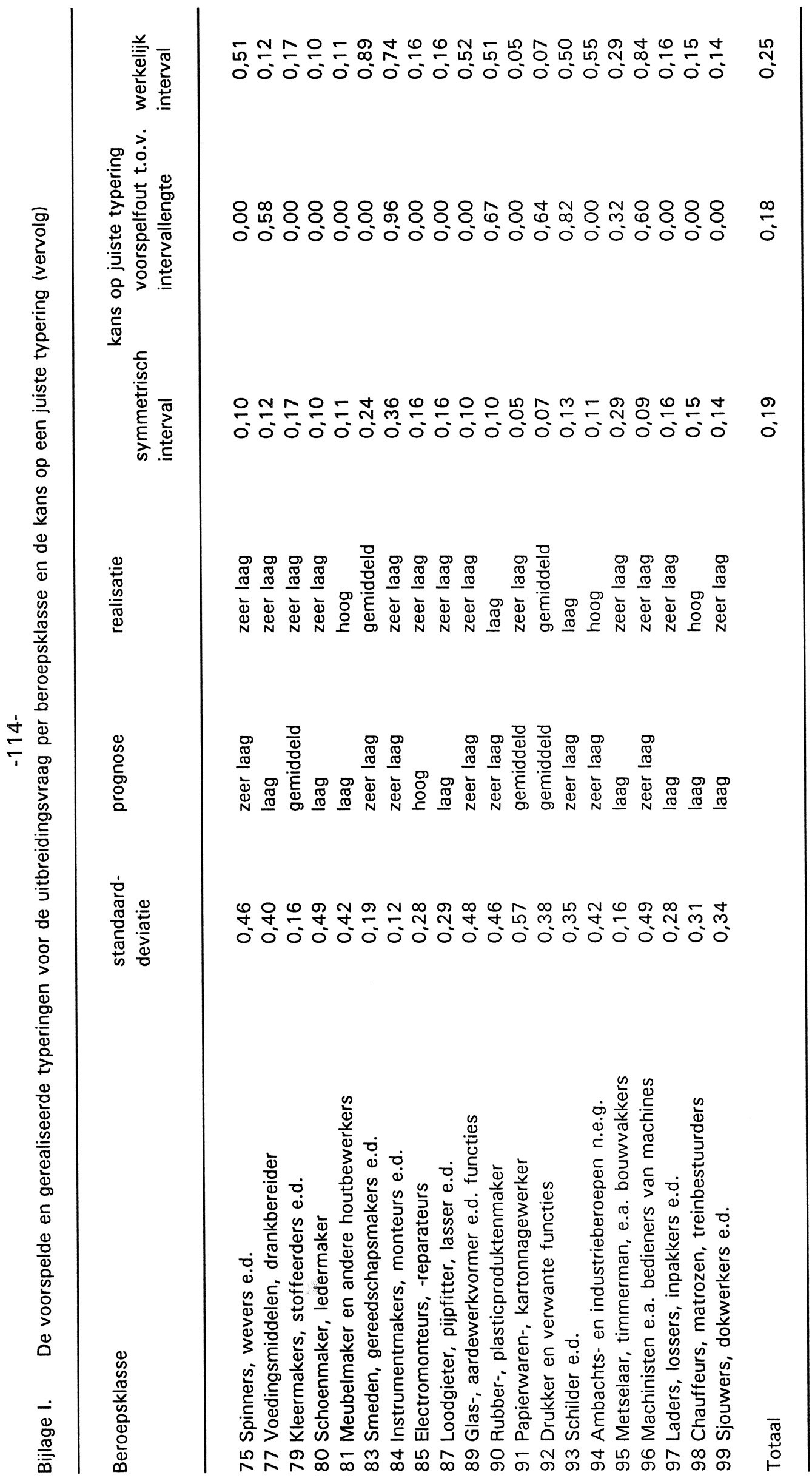




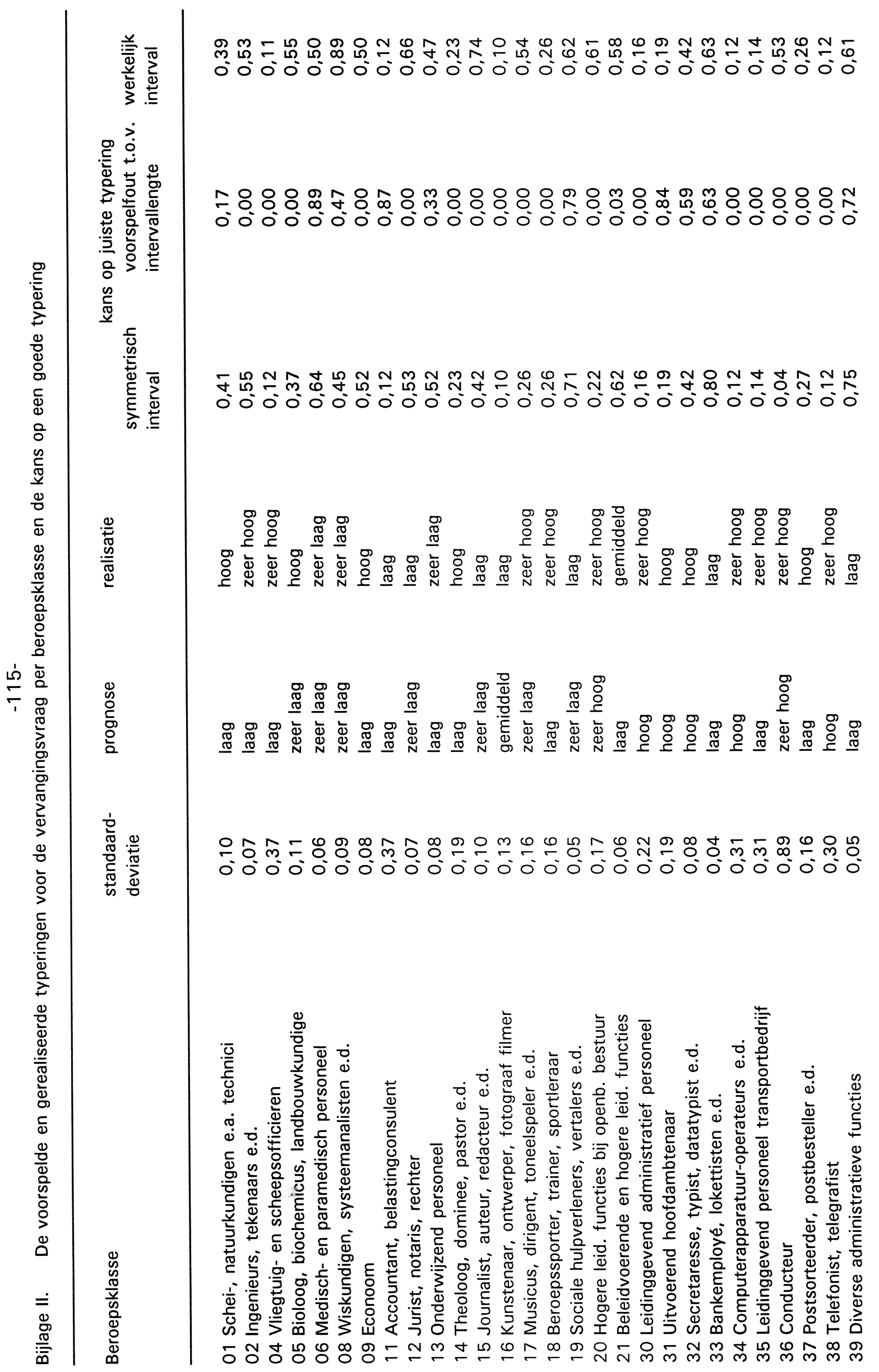




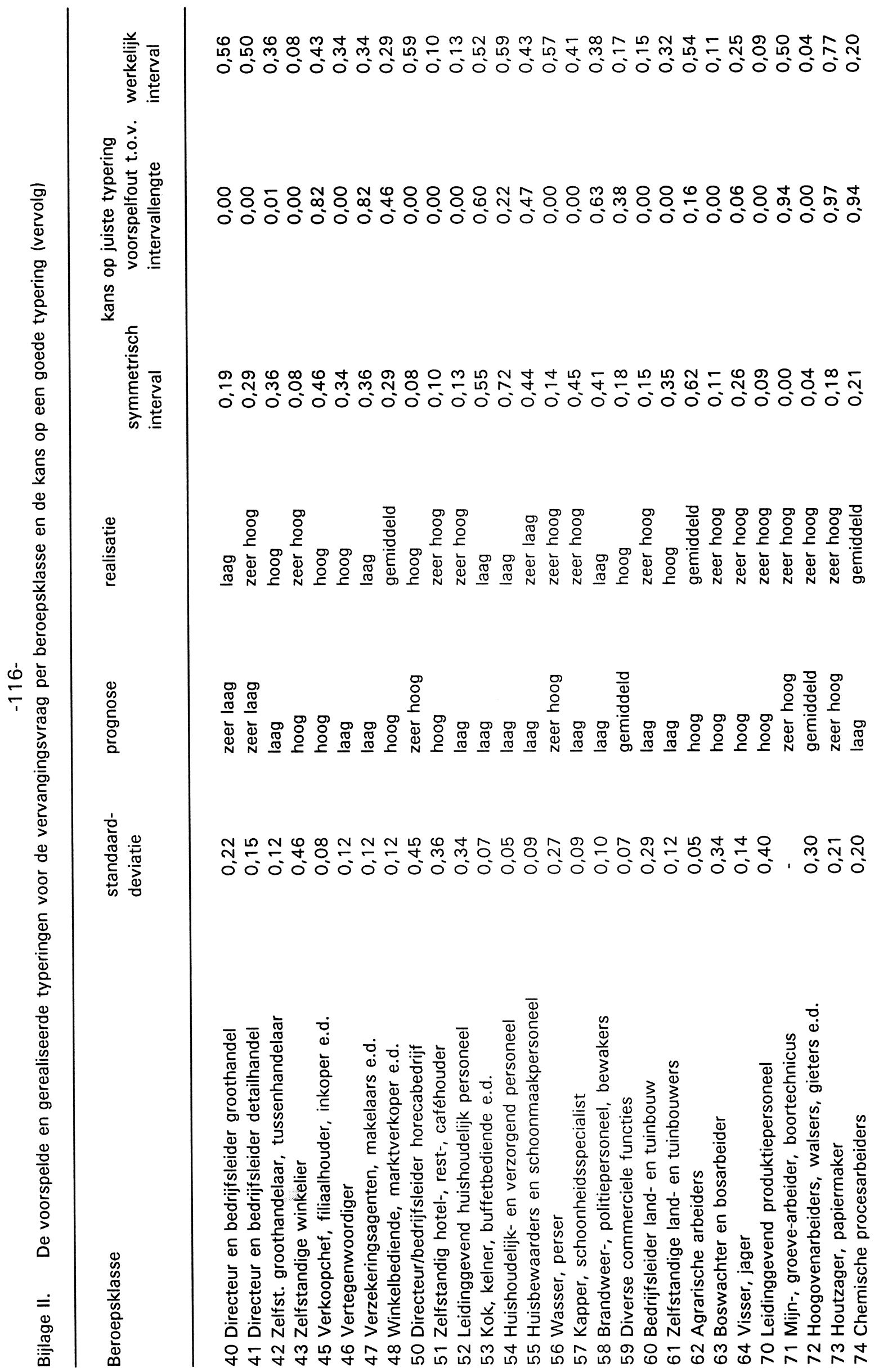




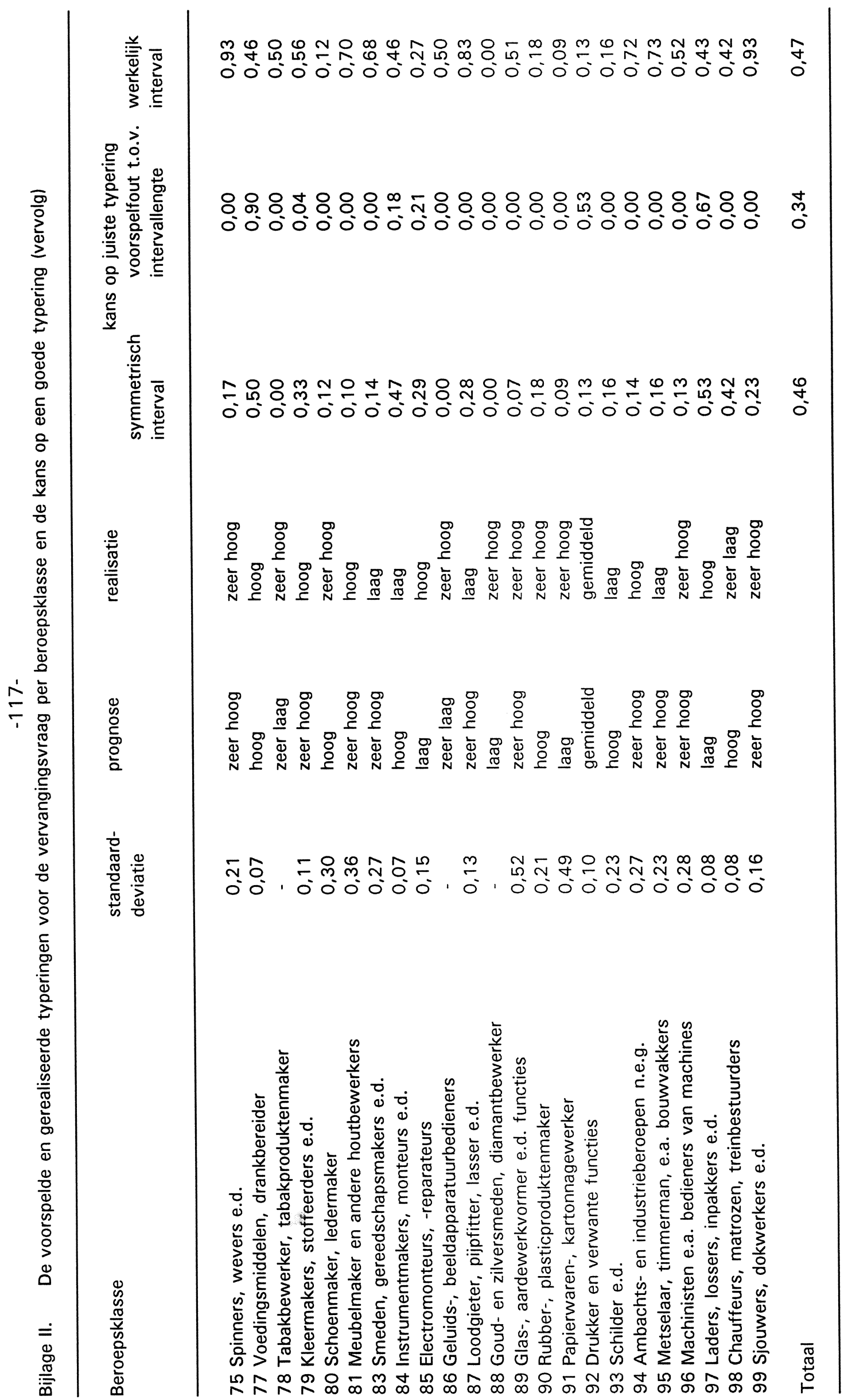




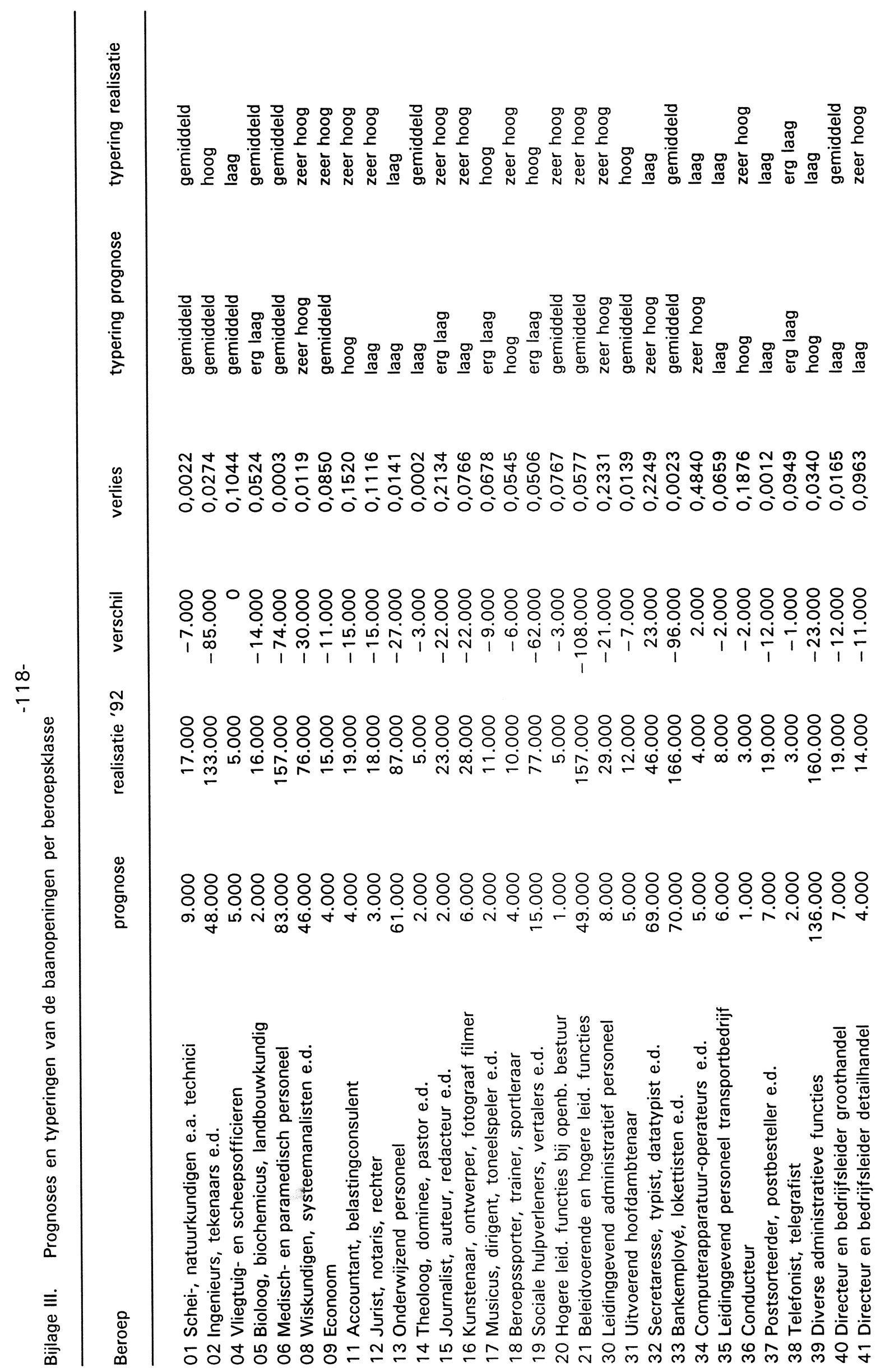




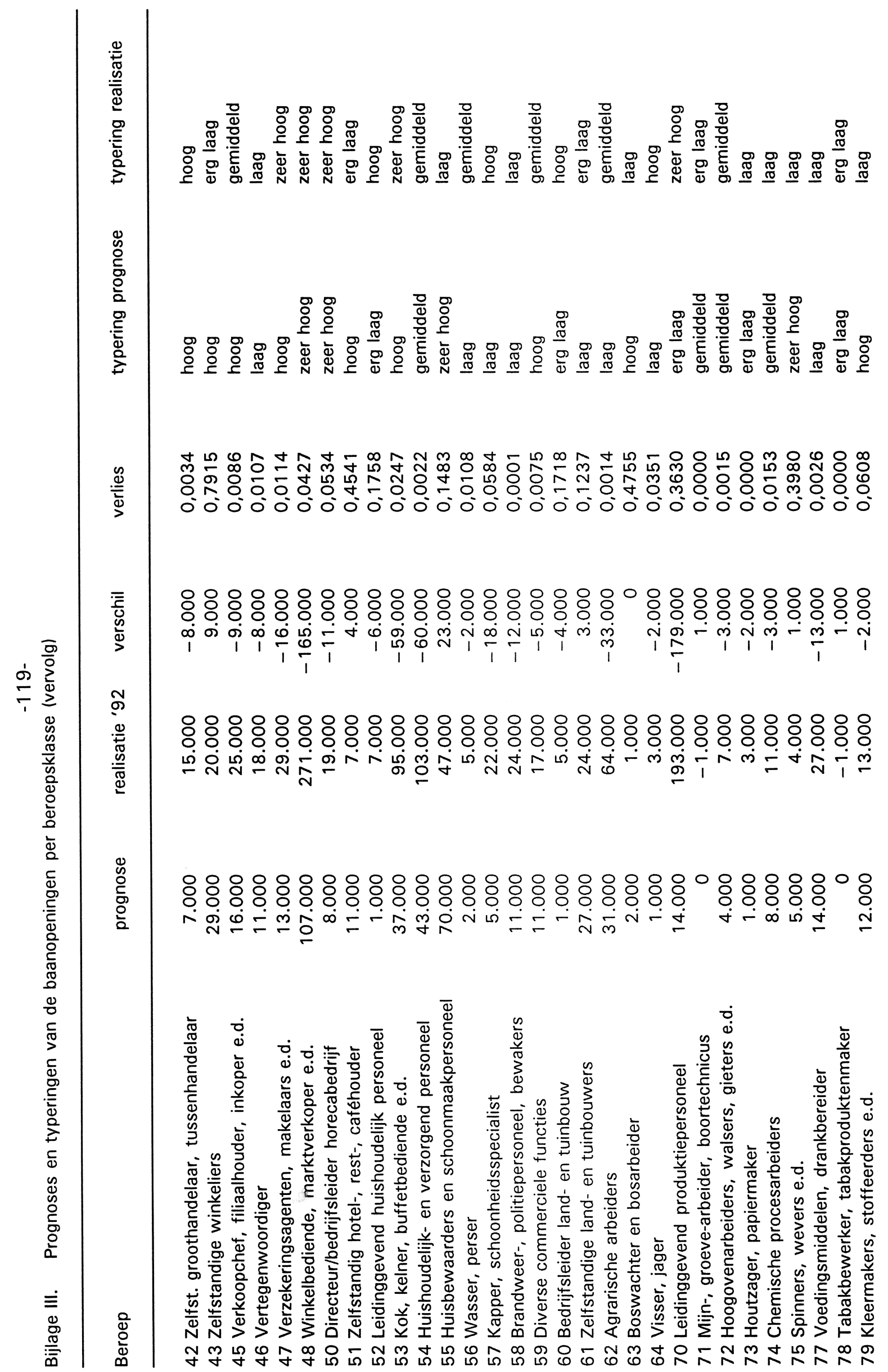




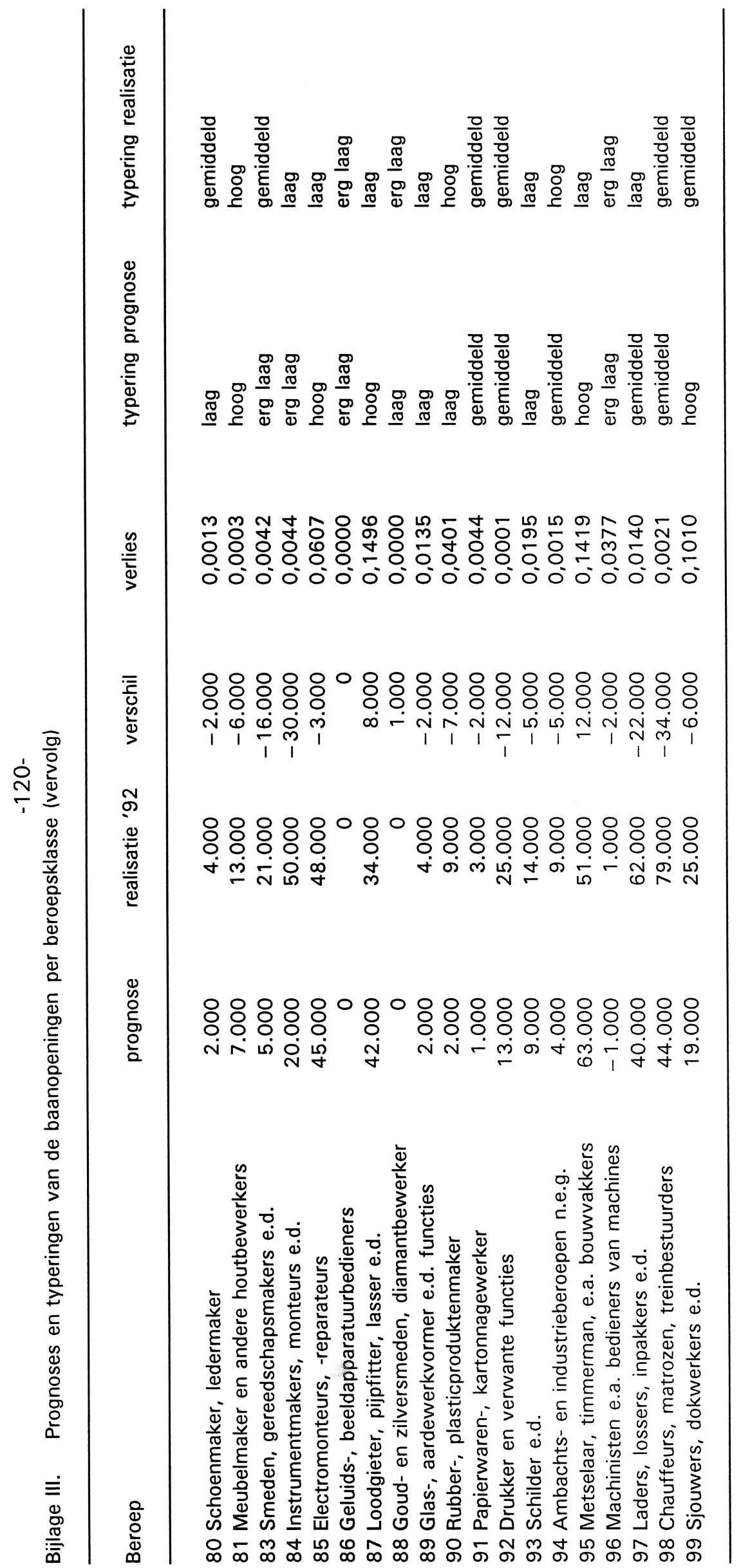




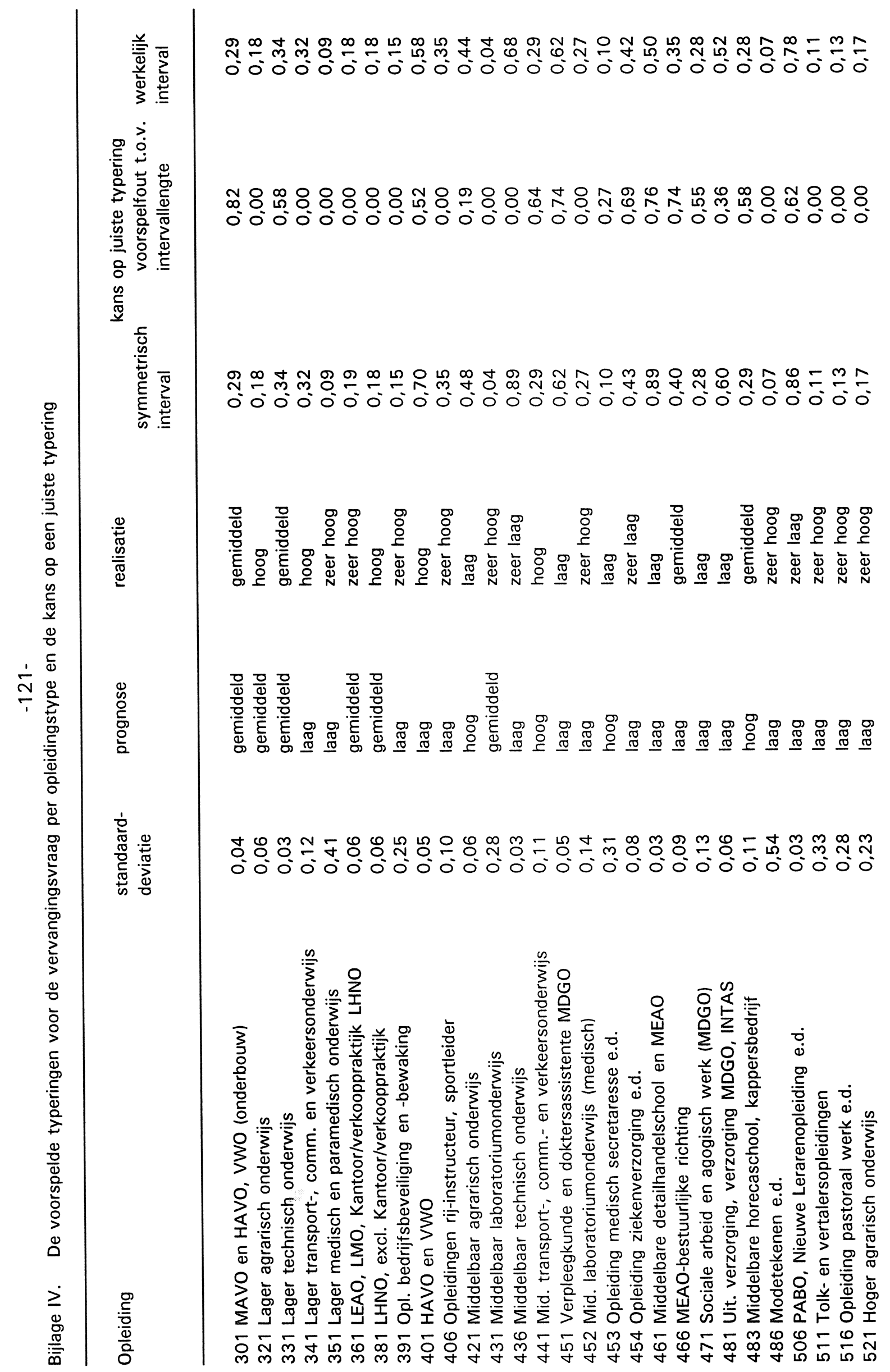




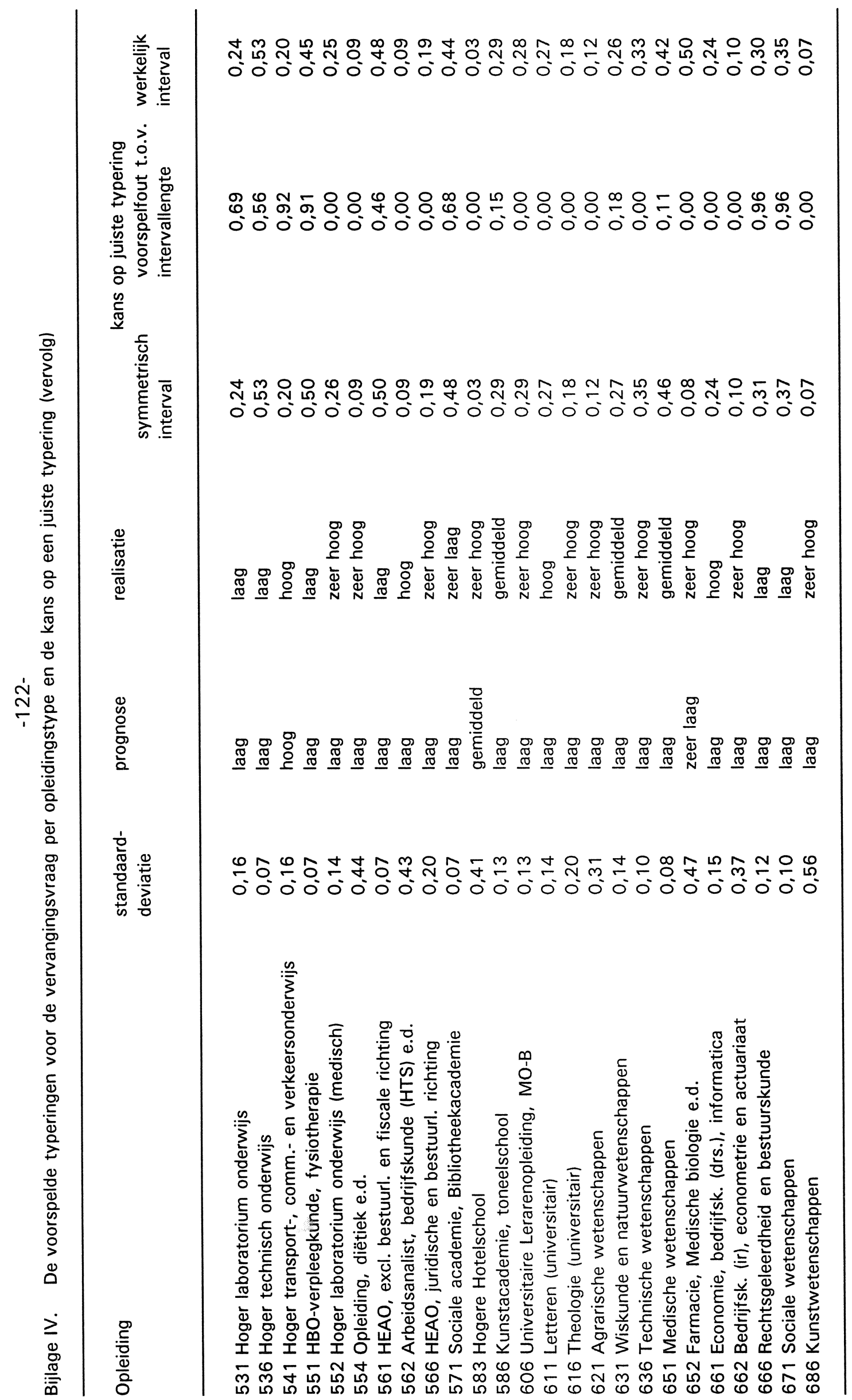




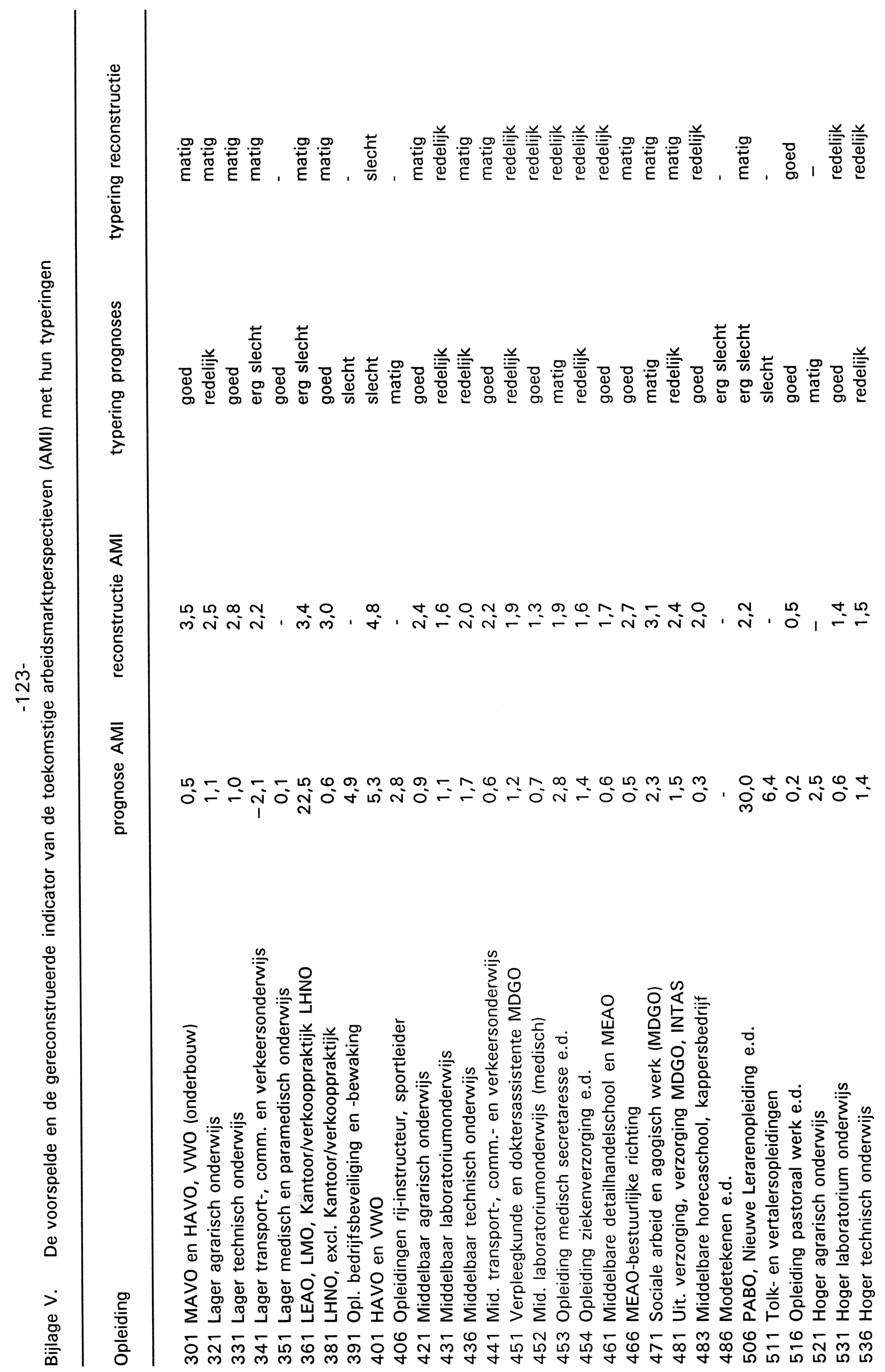




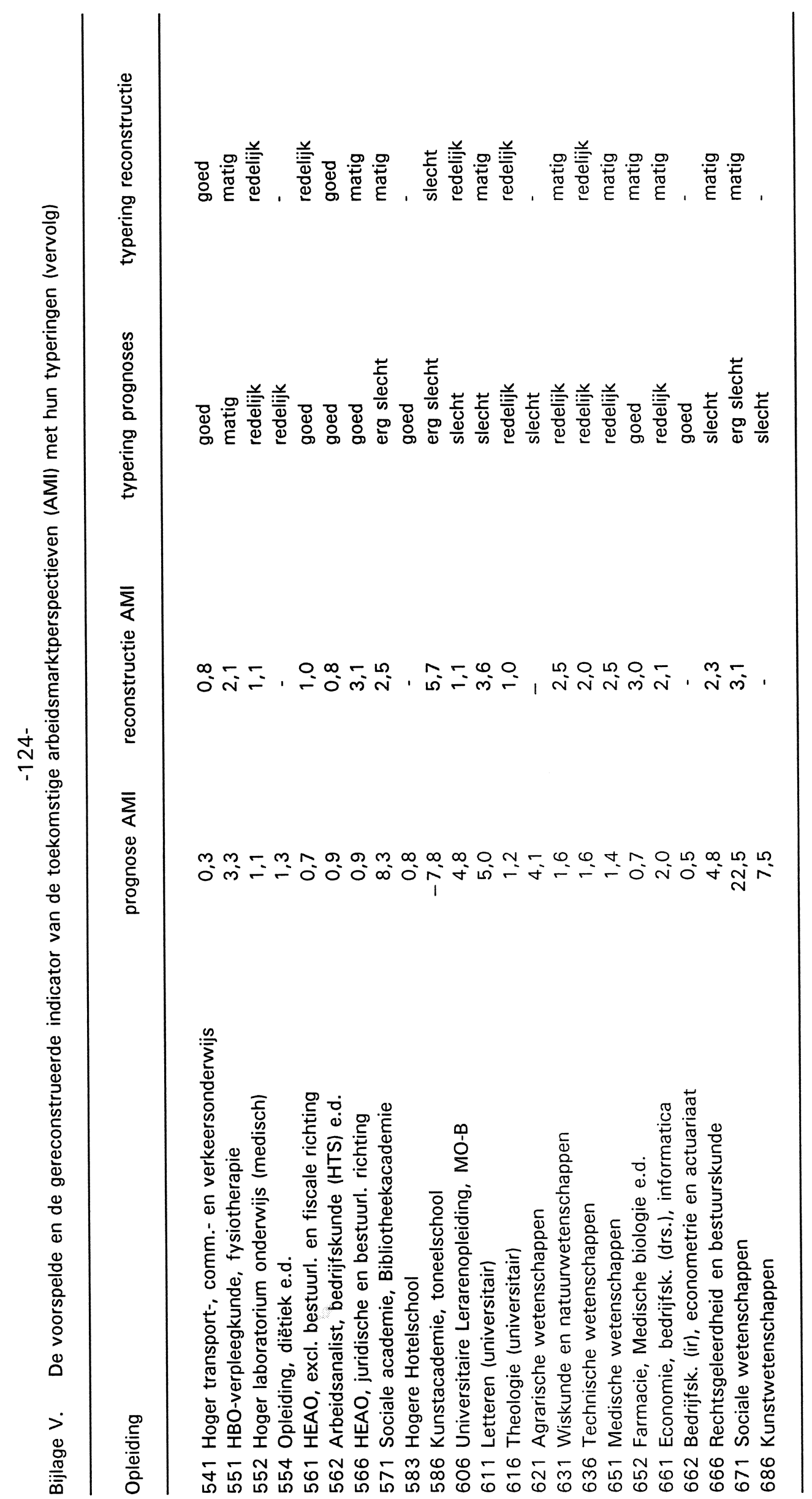

